\title{
Mycosphere Notes 102-168: Saprotrophic fungi on Vitis in China, Italy, Russia and Thailand
}

Jayawardena $\mathrm{RS}^{1,2}$, Hyde $\mathrm{KD}^{2}$, Chethana KWT ${ }^{1,2}$, Daranagama $\mathrm{DA}^{2}$, Dissanayake $\mathrm{AJ}^{1,2}$, Goonasekara ID $^{2}$, Manawasinghe $\mathrm{IS}^{1,2}$, Mapook $\mathrm{A}^{2,3}$, Jayasiri $\mathrm{SC}^{2}$, Karunarathna $\mathrm{A}^{2,4}$, Li $\mathrm{CG}^{2}$, Phukhamsakda $\mathrm{C}^{2}$, Senanayake $\mathrm{IC}^{2}$, Wanasinghe $\mathrm{DN}^{2}$, Camporesi $\mathrm{E}^{5,6}$, Bulgakov $\mathrm{TS}^{7}$, Li XH' ${ }^{1}$, Liu M' ${ }^{1}$, Zhang $\mathbf{W}^{1}$, Yan JY'

${ }^{1}$ Beijing Municipal Key Laboratory for Environmental Friendly Management on Pests of North China Fruits, Institute of Plant and Environment Protection, Beijing Academy of Agriculture and Forestry Sciences, Beijing, 100097, People's Republic of China

${ }^{2}$ Center of Excellence in Fungal Research, Mae Fah Luang University, Chiang Rai 57100, Thailand

${ }^{3}$ Key Laboratory for Plant Diversity and Biogeography of East Asia, Kunming Institute of Botany, Chinese Academy of Sciences, Kunming 650201, Yunnan, People's Republic of China

${ }^{4}$ Department of Entomology and Plant Pathology, Faculty of Agriculture, Chiang Mai University, Chiang Mai 50200, Thailand

${ }^{5}$ A.M.B. Gruppo Micologico Forlivese "Antonio Cicognani”, Via Roma 18, Forli, Italy

${ }^{6}$ A.M.B. Circolo Micologico "Giovanni Carini”, C.P. 314 Brescia, Italy

${ }^{7}$ Russian Research Institute of Floriculture and Subtropical Crops, 2/28 Yana Fabritsiusa Street, Sochi 354002, Krasnodar Region, Russia

Jayawardena RS, Hyde KD, Chethana KWT, Daranagama DA, Dissanayake AJ, Goonasekara ID, Manawasinghe IS, Mapook A, Jayasiri SC, Karunarathna A, Li CG, Phukhamsakda C, Senanayake IC, Wanasinghe DN, Camporesi E, Bulgakov TS, Li XH, Liu M, Zhang W, Yan JY 2018 Mycosphere Notes 102-168: Saprotrophic fungi on Vitis in China, Italy, Russia and Thailand. Mycosphere 9(1), 1-114, Doi 10.5943/mycosphere/9/1/1

\begin{abstract}
This is the third paper in the series, Mycosphere notes, wherein we provide notes on various fungal taxa. In this set of notes, we deal with species found on the grape genus, Vitis, one of the most important economically important crops, grown worldwide. We provide notes on 67 taxa, including two new species, Alternaria italica and Alfaria vitis, an asexual morph for Alfaria cyperiesculenti and 41 new host records or distribution records. The taxonomic placement of most taxa discussed in this study is based on a modern taxonomic framework based on analysis of multi-gene sequence data.
\end{abstract}

Key words - 2 new species - Alfaria vitis - Alternaria italica - Grapevine - Molecular phylogeny - New host records - Saprotrophs

Table of Contents

Ascomycota

Dothideomycetes O.E. Erikss. \& Winka

Botryosphaeriales C.L. Schoch, Crous \& Shoemaker

Botryosphaeriaceae Theiss. \& Syd.

Submitted 30 November 2017, Accepted 29 January 2018, Published online 5 February 2018

Corresponding Authors: JY Yan - e-mail - jiyeyan@vip.163.com and RS Jayawardena - e-mail -

ruvi.jaya@yahoo.com 
102. Botryosphaeria dothidea (Moug.) Ces. \& De Not.

103. Diplodia seriata De Not., Micr. Ital.

104. Dothiorella iberica A.J.L. Phillips, J. Luque \& A. Alves (new distribution record)

105. Dothiorella sarmentorum (Fr.) A.J.L. Phillips, A. Alves \& J. Luque

106. Neofusicoccum italicum Dissan. \& K.D. Hyde

107. Neofusicoccum parvum (Pennycook \& Samuels) Crous, Slippers \& A.J.L. Phillips

Capnodiales Woron.

Cladosporiaceae Nann.

108. Cladosporium cladosporioides (Fresen.) G.A. de Vries

109. Cladosporium cucumerinum Ellis \& Arthur (new host record)

Mycosphaerellaceae Lindau

110. Pseudocercospora vitis (Lév.) Speg. (new distribution record)

Dothideales Lindau

Saccotheciaceae Bonord.

111. Aureobasidium pullulans (de Bary) G. Arnaud (new distribution record)

Pleosporales Luttr. ex M.E. Barr

Amorosiaceae Thambugala \& K.D. Hyde

112. Angustimassarina populi Thambug. \& K.D. Hyde (new host record)

Didymellaceae Gruyter, Aveskamp \& Verkley

113. Didymella negeriana (Thüm.) Q. Chen \& L. Cai (new distribution record)

114. Didymella pomorum (Thüm.) Q. Chen \& L. Cai (new host record)

115. Epicoccum nigrum Link.

Didymosphaeriaceae Munk

116. Pseudocamarosporium propinquum (Sacc.) Wijayaw. (new host record)

Lophiostomataceae Sacc.

117. Lophiostoma macrostomum (Tode) Ces. \& De Not.

Massariaceae Nitschke

118. Neomassaria fabacearum Mapook, Camporesi \& K.D. Hyde (new host record)

Pleosporaceae Nitschke

119. Alternaria alternata (Fr.) Keiss1.

120. Alternaria italica J.F. LI, Camporesi \& K.D. Hyde sp. nov.

121. Alternaria vitis Cavara

122. Bipolaris maydis (Y. Nisik. \& C. Miyake) Shoemaker (new host record)

Teichosporaceae M.E. Barr

123. Floricola viticola Phukhams., Camporesi \& K.D. Hyde

Sordariomycetes O.E. Erikss. \& Winka

Amphisphaeriales D. Hawksw. \& O.E. Erikss.,

Sporocadaceae Corda

124. Neopestalotiopsis clavispora (G.F. Atk.) Maharachch., K.D. Hyde \& Crous (new host record)

125. Neopestalotiopsis vitis Jayawardena, Maharachch., Yan, Li \& Hyde

126. Pestalotiopsis chamaeropis Maharachch., K.D. Hyde \& Crous (new host record)

127. Pestalotiopsis sp.

128. Pseudopestalotiopsis camelliae-sinensis F. Liu \& L. Cai (new host record)

129. Seimatosporium vitis Y.P. Xiao, Camporesi \& K.D. Hyde

Sordariales Chadef. ex D. Hawksw. \& O.E. Erikss.

Chaetomiaceae G. Winter

130. Chaetomium globosum Kunze, in Kunze \& Schmidt (new distribution record)

Chaetosphaeriales Huhndorf, A.N. Mill. \& F.A. Fernández

Chaetosphaeriaceae Réblová, M.E. Barr \& Samuels

131. Pseudolachnea hispidula (Schrad.) B. Sutton (new host record) 
Diaporthales Nannf.

Diaporthaceae Höhn. ex Wehm.

132. Diaporthe ampelina (Berk. \& M.A. Curtis) R.R. Gomes, Glienke \& Crous

133. Diaporthe rudis (Fr.) Nitschke (new distribution record)

134. Diaporthe eres Nitschke

Schizoparmaceae Rossman, D.F. Farr \& Castl.

135. Coniella vitis Chethana, Yan, Li \& K.D. Hyde

Glomerellales Chadef. ex Réblová, W. Gams \& Seifert

Glomerellaceae Locq. ex Seifert \& W. Gams

136. Colletotrichum dematium (Pers.) Grove (new distribution record)

137. Colletotrichum godetiae Neerg. (new distribution record)

138. Colletotrichum hebeiense X.H. Li, Y. Wang, K.D. Hyde, M.M.R.S. Jayawardena \& J.Y.

Yan (new life mode record)

139. Colletotrichum siamense Prihast., L. Cai \& K.D. Hyde (new distribution record)

140. Colletotrichum viniferum L.J. Peng, L. Cai, K.D. Hyde \& Zi Y. Ying (new record as a

pathogen on grape cluster stem)

141. Colletotrichum truncatum (Schwein.) Andrus \& W.D. Moore (new host record)

Xylariales Nannf

Diatrypaceae Nitschke

142. Cryptovalsa ampelina (Nitschke) Fuckel, Jb. Nassau

Hypocreales Lindau

Hypocreaceae De Not.

143. Trichoderma atroviride $\mathrm{P}$. Karst. (new host record)

144. Trichoderma lixii (Pat.) P. Chaverri (new host record)

145. Trichoderma harzianum Rifai (new host record)

Nectriaceae Tul. \& C. Tul.

146. Fusarium oxysporum Schltdl.

147. Fusarium sambucinum Fuckel

Stachybotriaceae L. Lombard \& Crous

148. Albifimbria verrucaria (Alb. \& Schwein.) L. Lombard \& Crous (new host record)

149. Albifimbria viridis L. Lombard \& Crous (new host record)

Hypocreales incertae sedis

150. Alfaria cyperi-esculenti Crous, Montaño-Mata \& García-Jim. (new host record)

151. Alfaria vitis Manawasinghe, Camporesi \& K.D. Hyde, sp. nov

Xylariales genera incertae sedis

152. Neoanthostomella viticola Daranagama, Camporesi \& K.D. Hyde

Leotiomycetes O.E. Erikss. \& Winka

Helotiales Nannf. ex Korf \& Lizoň

Sclerotiniaceae Whetzel

153. Botrytis cinerea Pers.

Mucoromycetes Doweld

Mucorales Fr.,

Mucoraceae Dumort.

154. Actinomucor elegans (Eidam) C.R. Benj. \& Hesselt. (new distribution record)

155. Mucor racemosus Bull. (new distribution record)

156. Mucor circinelloides Tiegh. (new distribution record)

Rhizopodaceae K. Schum.

157. Rhizopus oryzae Went \& Prins. Geerl. (new host record)

Eurotiomycetes O.E. Erikss. \& Winka 
Eurotiales G.W. Martin ex Benny \& Kimbr

Trichocomaceae E. Fisch.

158. Aspergillus aculeatus lizuka (new distribution record)

159. Aspergillus niger Tiegh.

160. Penicillium brevicompactum Dierckx (new host record)

161. Penicillium citrinum Thom (new host record)

162. Penicillium terrigenum Houbraken, Frisvad \& Samson (new host record)

163. Talaromyces amestolkiae N. Yilmaz, Houbraken, Frisvad \& Samson (new host record)

164. Talaromyces pinophilus (Hedgc.) Samson, N. Yilmaz, Frisvad \& Seifert (new host record)

165. Talaromyces purpureogenus Samson, N. Yilmaz, Houbraken, Spierenb., Seifert, Peterson, Varga \& Frisvad (new host record)

Agaricomycetes Doweld

Cantharellales Incertae sedis

166. Minimedusa sp. (new host record)

Peniophoraceae Lotsy

167. Peniophora sp. (new host record)

\section{Oomycota Incertae sedis}

Pythiaceae J. Schröt.

168. Pythium amasculinum Y.N. Yu (new host record)

\section{Introduction}

This paper is a continuation of the series, Mycosphere notes, which provides notes on new species and new records of fungal taxa (Thambugala et al. 2017, Boonmee et al. 2017). In this paper we provide notes, illustrations, descriptions and phylogenies of 67 fresh collections of saprotrophs and pathogens from the grape genus, Vitis. Grapes are an economically important crop belonging to the family Vitaceae and commonly known as grapevine (Fig. 1). Grapes are used both for direct consumption and for the production of wine. This genus comprises 79 accepted species of perennial woody and herbaceous vines. Species of Vitis are dioecious and highly heterozygous as a result of enforced outcrossing (Walker 2015). Most Vitis species are found in the temperate regions of the Northern Hemisphere in North America and Asia, with a few species in the tropics. Vitis species are wind pollinated. Vitis can be distinguished from other genera of Vitaceae by having petals which remain joined at the tip and detach from the base to fall together as a calyptras (Stace 2010). Vitis is often divided into two sections based on the number of chromosomes; Vitis and Muscadina (Walker 2015). All species within the Vitis section are interfertile and have 38 chromosomes, while species within the Muscadine section have 40 chromosomes (Bennet \& Leitch 2012). There are thousands of cultivars of $V$. vinifera L., a species that is grown around the globe. This species is highly important in production of wine, raisins, as well as table grapes.

There have been a few thorough studies of major pathogens on grapes using both morphology and phylogeny (Úrbez-torrez et al. 2012, 2013, Dissanayake et al. 2015, Jayawardena et al. 2015, 2016, Chethana et al. 2017). Even though a number of sexual and asexual fungal taxa have been reported on Vitis species, updated information of the taxa present in this genus is lacking. Only some have good illustrations and gene sequence data.

In this study, we collected fungi on Vitis species in China, Italy, Thailand and Russia. Comprehensive descriptions with detailed illustrations of these fresh collections, together with multi-gene phylogenetic analyses, were used to establish their taxonomic placements. We treat 67 taxa belonging to Amorosiaceae, Botryosphaeriaceae, Chaetomiaceae, Chaetosphaeriaceae, Cladosporiaceae, Diaporthaceae, Didymellaceae, Didymosphaeriaceae, Diatrypaceae, Glomerellaceae, Hypocreaceae, Lophiostomataceae, Massariaceae, Mucoraceae, 
Mycosphaerellaceae, Nectriaceae, Peniophoraceae, Pleosporaceae, Pythiaceae, Rhizopodaceae, Saccotheciaceae, Schizoparmaceae, Sclerotiniaceae, Sporocadaceae, Stachybotriaceae, Teichosporaceae and Trichocomaceae.
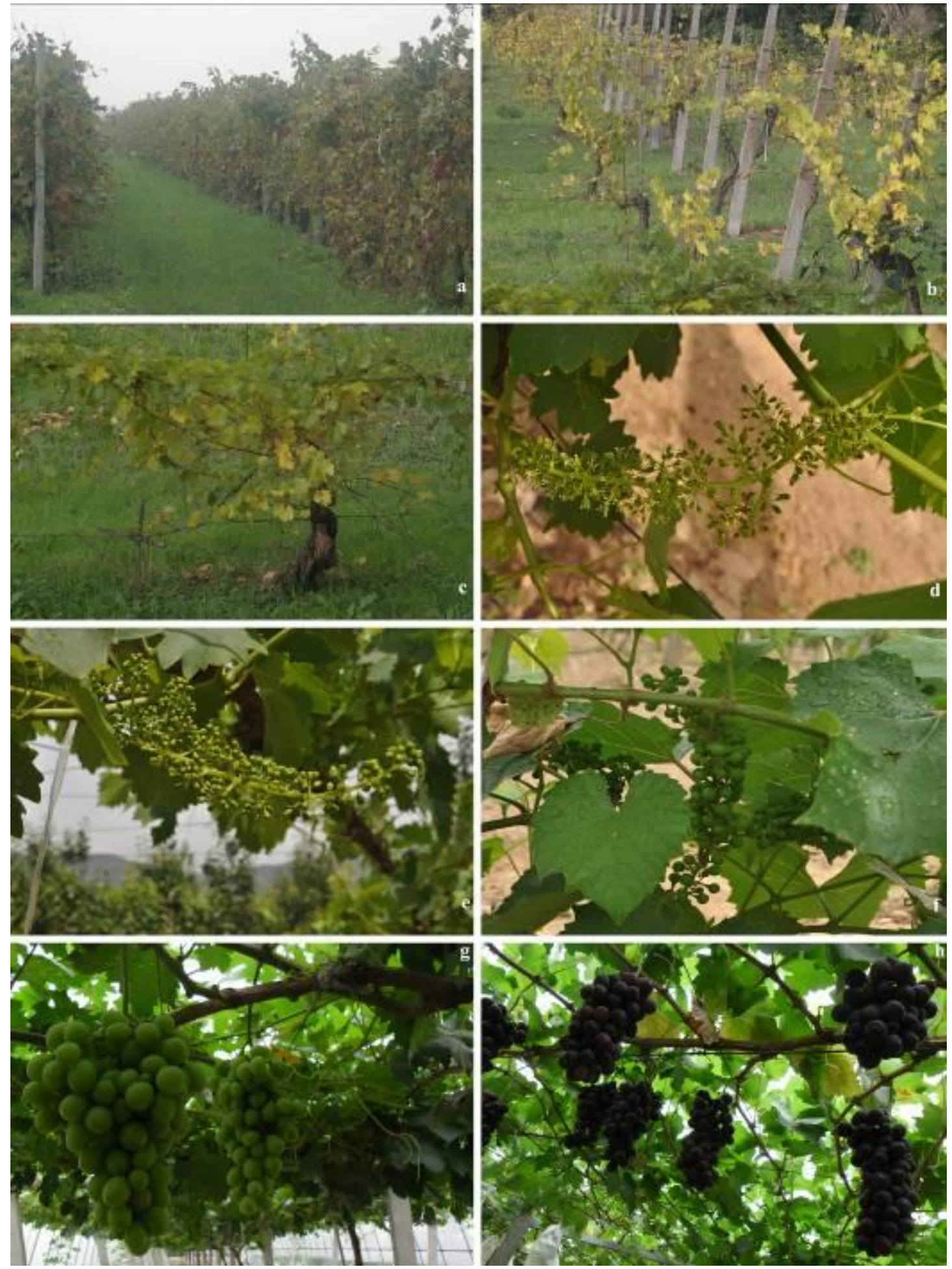

Fig. 1 - a-c Habitats d-e Inflorescences f Immature fruits g-h Mature fruits.

\section{Material \& Methods}

\section{Collection and Isolation}

Fungal species associated with Vitis vinifera. were collected from China (Beijing, Sichuan and Yunnan Provinces), Italy (Province of Forlì-Cesena), Russia (Rostov Region) and Thailand (Chiang Saen). Specimens were incubated in a moist chamber for 3-7 days at $25^{\circ} \mathrm{C}$, to induce sporulation. Fungi were isolated by a modified single spore isolation method (Manamgoda et al. 
2012, Chomnunti et al. 2014). Growth rate, colony characteristics and sexual/asexual morph morphology were determined from cultures grown on potato dextrose agar (PDA) at $25-28^{\circ} \mathrm{C}$, under $12 \mathrm{~h}$ light/12 h dark. Fungal mycelia and spores were examined by differential interference contrast (DIC) and photographed with an axio Imager Z2 photographic microscope (Carl Zeiss Microscopy, Germany). Forty conidial measurements were taken for each isolate. All microscopic measurements were recorded with ZeM PRo 2012 software. Representative specimens are deposited in the herbarium of Mae Fah Luang University, Chiang Rai, Thailand (MFLU) and in Kunming, China (KIB). Representative cultures are deposited at Mae Fah Luang Culture Collection (MFLUCC), Beijing Academy of Agriculture and Forestry Sciences, China (JZB) and Kunming Culture Collection (KUMCC). Faces of fungi numbers and Index Fungorum numbers were obtained as outlined in Jayasiri et al. (2015) and Index Fungorum (2018).

DNA extraction, PCR amplification and sequencing

DNA extraction followed the method of Thambugala et al. (2015). The PCR amplifications were performed in a total volume of $25 \mu \mathrm{l}$ of PCR mixture containing TaKaRa Ex-Taq DNA polymerase $0.3 \mu \mathrm{l}, 12.5 \mu \mathrm{l}$ of $2 \times$ PCR buffer, $2.5 \mu \mathrm{l}$ of dNTPs, $1 \mu \mathrm{l}$ of genomic DNA, $1 \mu \mathrm{l}$ of each primer and $12.2 \mu \mathrm{l}$ of ddH2O. The ACT, CAL, CHS, TEF1, GAPDH, ITS, LSU, SSU, RPB2 and TUB2 gene regions were amplified for relevant strains following the conditions stipulated in Table 1. The PCR products were verified by staining with ethidium bromide after separation on $1.2 \%$ agarose electrophoresis gels and purified according to the manufacturer's instructions of a Qiangen purification kit (Qiagen, Hilden, Germany). DNA sequencing was done by Sunbiotech Company, Beijing, China. The DNA sequences generated in this study are deposited in GenBank.

Phylogenetic analysis

Based on blast searches in GenBank, using LSU or ITS sequence data, specific genera were identified. Additional sequences were downloaded from GenBank, based on blast searches and recent publications. Separate phylogenetic analyses were carried out to determine the placement of each fungal taxon based on selected ACT, CAL, CHS, TEF1, GAPDH, ITS, LSU, SSU, RPB2 and TUB2 sequence data. DNAStar V.5.1 and SeqMan V.5.0 were used to obtain consensus sequences from sequences generated from forward and reverse primers. Sequences were aligned with Clustal $\mathrm{X}$ v.1.81 (Thompson et al. 1997). The sequences were further aligned using default settings of MAFFT v.7 (Katoh \& Toh 2008, http://mafft.cbrc.jp/alignment/server/) and manually adjusted using BioEdit V.7.0.9.0 (Hall 1999) where necessary.

Maximum parsimony analysis (MP) was performed using PAUP v. 4.0b10 (Swofford 2002) to obtain the most parsimonious trees. Gaps were treated as missing data and ambiguously aligned regions were excluded. Trees were inferred using the heuristic search option with Tree Bisection Reconnection (TBR) branch swapping and 1000 random sequence additions. Maxtrees were set up to 5,000, branches of zero length were collapsed and all multiple parsimonious trees were saved. Descriptive tree statistics for parsimony (tree length [TL], consistency index [CI], retention index $[\mathrm{RI}]$, rescaled consistency index [RC], and homoplasy index [HI]) were calculated for trees generated under different optimality criteria. The robustness of the most parsimonious trees was evaluated by 1000 bootstrap replications resulting from maximum parsimony analysis (Hillis \& Bull 1993). Kishino-Hasegawa tests (KHT) (Kishino \& Hasegawa 1989) were performed in order to determine whether trees were significantly different. Bayesian inference (BI) was used in addition to construct the phylogenies using Mr. Bayes v.3.1.2 (Ronquist \& Huelsenbeck 2003). MrModeltest v. 2.3 (Nylander 2004) was used to carry out statistical selection of best-fit model of nucleotide substitution. Six simultaneous Markov chains were run for 1000000 generations and trees were sampled every 100th generation. The 2000 trees representing the burn-in phase of the analyses were discarded and the remaining 8000 trees used for calculating posterior probabilities (PP) in the majority rule consensus tree.

Maximum likelihood analysis was performed in raxmlGUIv.0.9b2 (Silvestro \& Michalak 2010). The RAxML analyses were run with a rapid bootstrap analysis using a random starting tree 
and 1000 ML bootstrap replicates. The search strategy was set to rapid bootstrapping with one thousand non parametric bootstrapping iterations using the general time reversible model (GTR) with a discrete gamma distribution. The best scoring tree was selected.

Trees were rooted with given outgroups in each analysis. The best scoring trees were selected and visualized in Treeview (Page 1996). MP/ML bootstrap supports (BS) (greater than or equal to $70 \%$ ) and Bayesian posterior probability (greater than or equal to 0.90 ) are shown below or above each branch. All the sequences newly generated in this study listed in Table 2. The resulting phylogenetic trees are presented under each relevant description. Alignments are deposited in TreeBASE under S21936.

\section{Results}

Taxonomy

In this study 67 fungal taxa were studied in 42 genera and 27 families. Species descriptions, phylogenetic results and notes are presented under the relevant family and genus.

\section{Ascomycota}

The treatment of classes, orders, families and genera of Ascomycota by Wijayawardene et al. (2018) is followed here.

\section{Dothideomycetes}

Botryosphaeriales C.L. Schoch, Crous \& Shoemaker, in Schoch, Shoemaker, Seifert, Hambleton, Spatafora \& Crous, Mycologia 98(6): 1050 (2007) [2006]

Botryosphaeriaceae Theiss. \& Syd., Annls mycol. 16(1/2): 16 (1918)

This family is one of the largest in the class Dothideomycetes. Members of this family are plant pathogens, endophytes or saprotrophs (Liu et al. 2013, Hyde et al. 2013). They have a wide distribution and have been recorded from grapevine as pathogens as well as endophytes and saprotrophs (Philips et al. 2013, Jayawardena et al. 2018).

Botryosphaeria Ces. \& De Not., Comm. Soc. crittog. Ital. 1(fasc. 4): 211 (1863)

Species of this genus are well-known pathogens on Vitis vinifera causing die back (ÚrbezTorres 2011). Currently this genus comprises ten species (Dissanayake et al. 2016). We show the placement of our strains in Botryosphaeria where they cluster with B. dothidea (Fig. 2).

Botryosphaeria dothidea (Moug.) Ces. \& De Not., Comm. Soc. crittog. Ital. 1(fasc. 4): 212 (1863)

Facesoffungi number: FoF03512

Saprotrophic on dead and aerial branches of Vitis vinifera. Sexual morph: Ascomata 200-350 $\mu \mathrm{m}$ diam., 175-280 $\mu \mathrm{m}$ high, erumpent, aggregated or solitary, globose with a central ostiole. Peridium comprising 5-10 layers of textura angularis, outer region of dark brown cells, inner region of 2-4 layers of hyaline cells lining the locule. Hamathecium comprising 2-4 $\mu \mathrm{m}$ wide cells. Pseudoparaphyses filiform, septate, constricted at the septa, rarely branched. Asci 60 $120 \times 15-21 \mu \mathrm{m}(\bar{x}=95 \times 18 \mu \mathrm{m}, \mathrm{n}=30), 8$-spored, bitunicate, fissitunicate, cylindrical, forming between pseudoparaphyses, pedicellate, rounded at the apex, with an ocular chamber. Ascospores 20-24×6-8 $\mu \mathrm{m}(\bar{x}=23 \times 6 \mu \mathrm{m}, \mathrm{n}=30)$, fusoid to ovoid, sometimes with tapered ends and appearing spindle-shaped, biseriate in the ascus. Asexual morph: Conidiomata stromatic, $250-450 \mu \mathrm{m}$ $(\bar{x}=320 \mu \mathrm{m}, \mathrm{n}=20)$. Paraphyses hyaline, septate, up to $100 \mu \mathrm{m}$ long, tapering to acutely rounded apices. Conidiophores hyaline, cylindrical, smooth. Conidiogenous cells hyaline, sub-cylindrical, 4-16 $\times 2-5 \mu \mathrm{m}(\bar{x}=8 \mu \mathrm{m}, \mathrm{n}=20)$. Conidia $15-26 \times 5-9 \mu \mathrm{m}(\bar{x}=18 \mu \mathrm{m} \mathrm{n}=40)$, hyaline, unicellular, narrowly fusiform, with a sub-truncate to bluntly rounded base, forming a septum before germination, smooth-walled with a granular content.

Culture characteristics - Colonies olivaceous, becoming grey, reverse black. Mycelial mat moderately dense, margin smooth. Colony on PDA reaching $50 \mathrm{~mm}$ diam. after $4 \mathrm{~d}$ at $28{ }^{\circ} \mathrm{C}$. 
Material examined - ITALY, Province of Forlì-Cesena, Teodorano - Meldola, on dead aerial branch of Vitis vinifera, 21 February 2015, Erio Camporesi IT 2385 (MFLU 15-3509), culture MFLUCC 17-0961; CHINA, Beijing, on dead branch of $V$. vinifera, 3 June 2015, Ruvishika S. Jayawardena, culture JZB310176.

Notes - Botryosphaeria dothidea has been isolated from almost all grape growing regions in the world (Phillips et al. 2013, Dissanayake et al. 2016). According to the combined phylogenetic analysis of ITS and EF gene regions, the isolates obtained from Vitis vinifera clustered with Botryosphaeria dothidea with a high bootstrap support (Fig. 2).

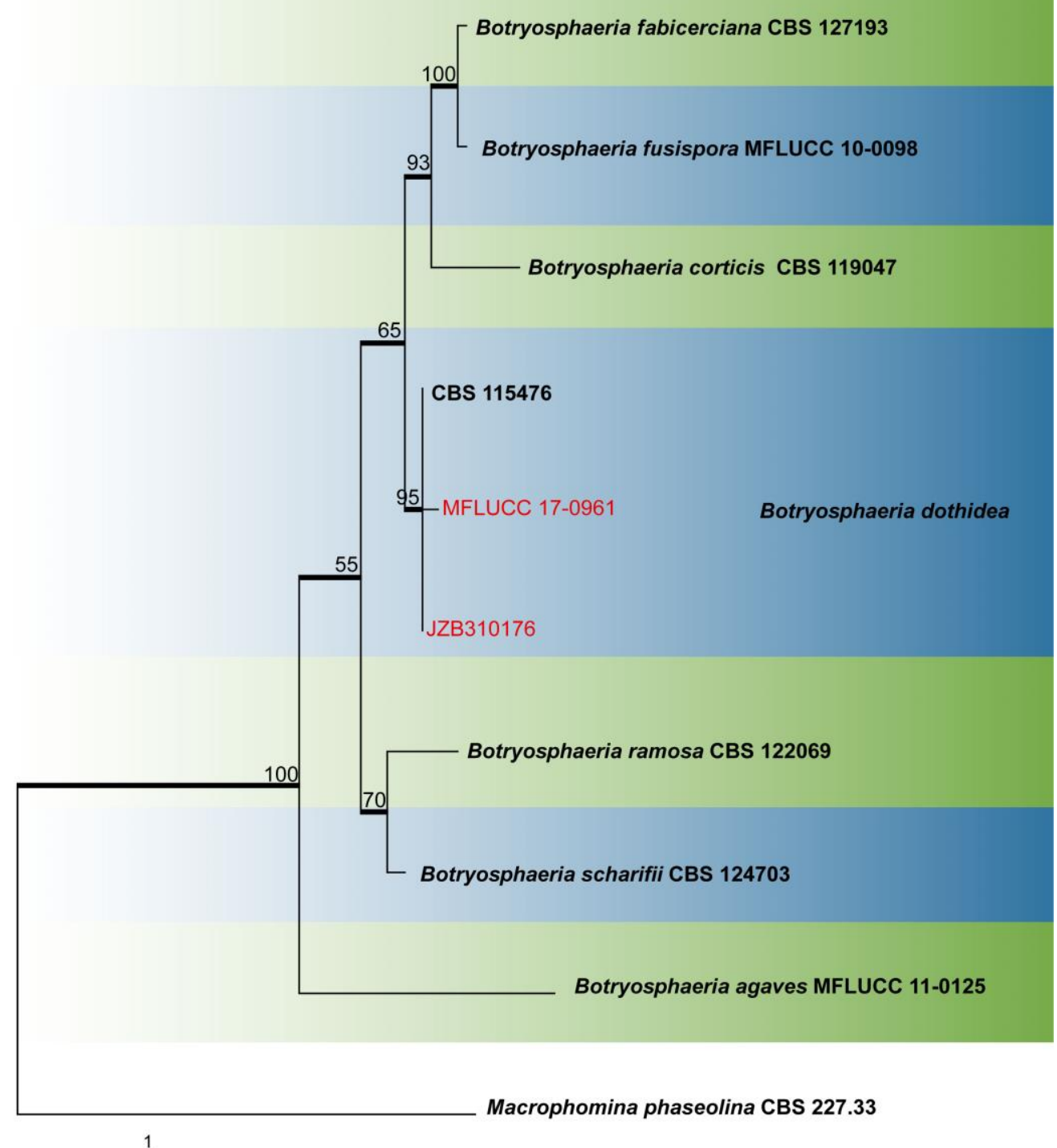

Fig. 2 - RAxML phylogram obtained from the combined ITS and TEF1 sequence data of Botryosphaeria species. Ex-type strains are in bold. The strains isolated in this study are shown in red. RAxML bootstrap support (BS) values $\geq 50 \%$ are shown at the nodes and branches with Bayesian posterior probability scores $\geq 0.90$ given in bold. The tree is rooted with Macrophomina phaseolina (CBS 227.33). 

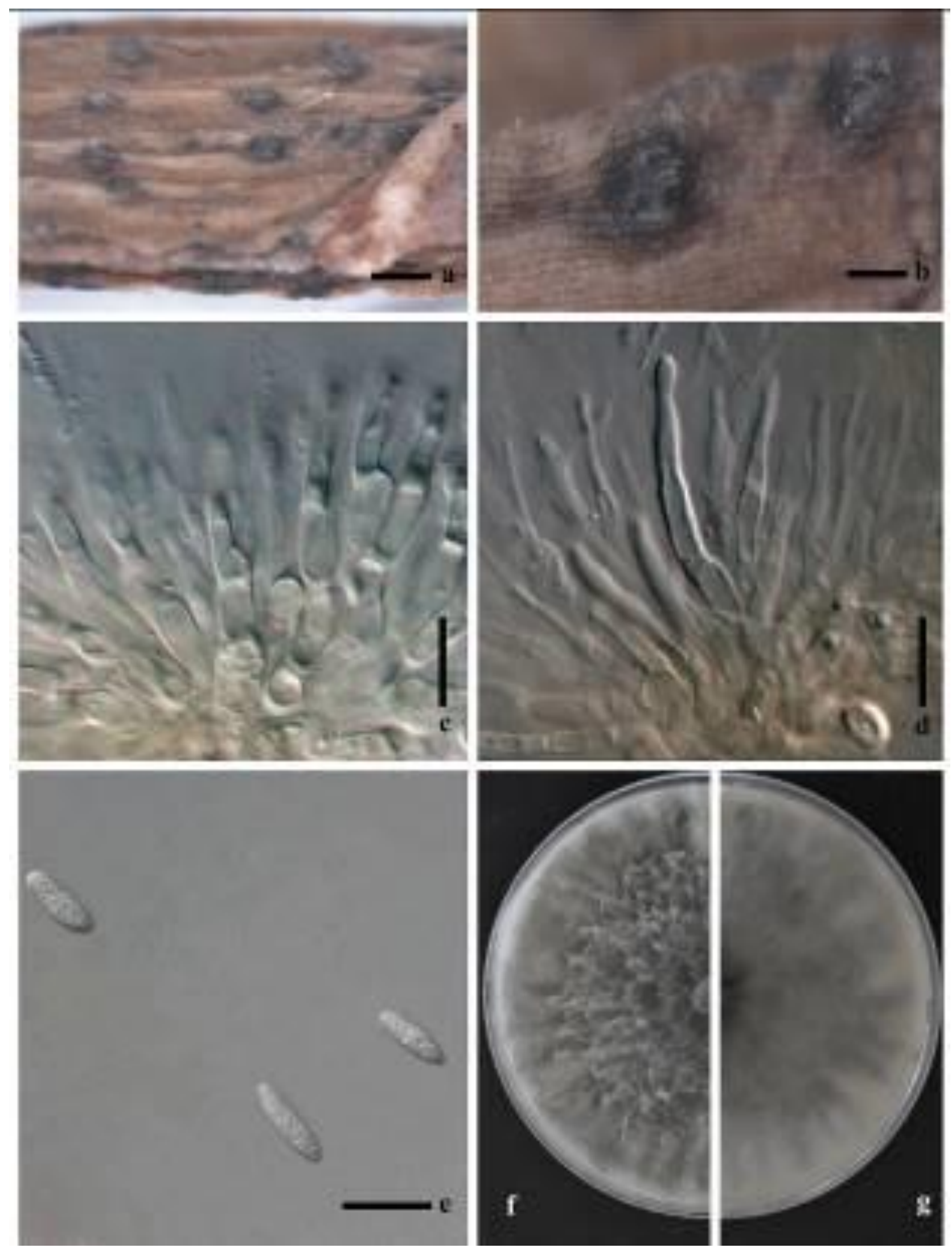

Fig. 3 - Asexual morph of Botryosphaeria dothidea. a, b. Appearance of conidiomata on host. c, d. Conidiophores. e. Conidia. f. Upper view of 7 day old culture. g. Reverse view of 7 day old culture. Scale bars: a, b=0.2 mm, c, d, e=20 $\mu \mathrm{m}$. 

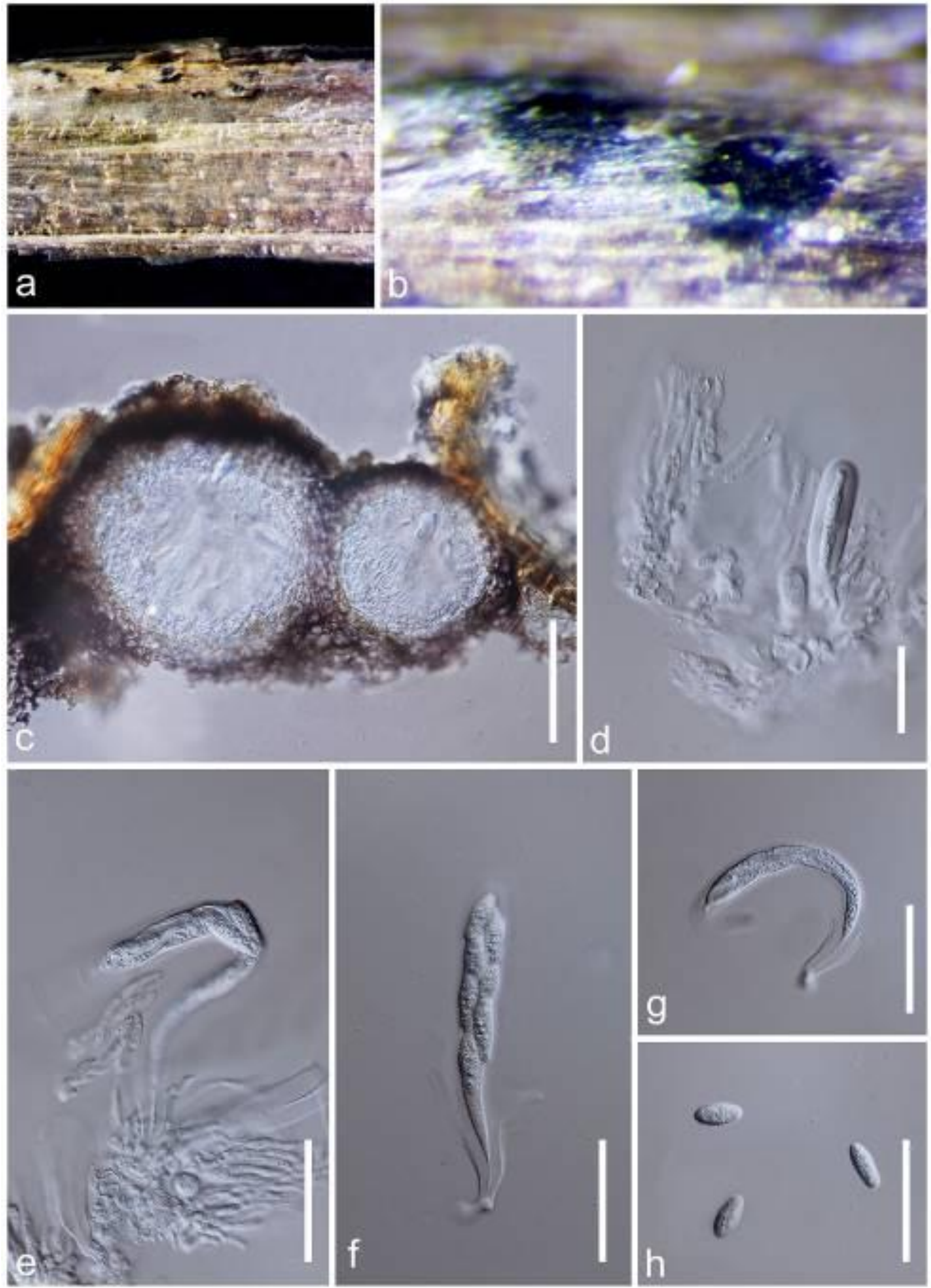

Fig. 4 - Sexual morph of Botryosphaeria dothidea. a, b. Appearance of ascomata immersed on host surface. c. Section through ascomata (immersed in host fungi). d, g. Immature asci. e, f. Mature bitunicate asci. h. Ascospores. Scale bars: $c=100 \mu \mathrm{m}, \mathrm{d}-\mathrm{h}=50 \mu \mathrm{m}$. 
Diplodia Fr., in Montagne, Annls Sci. Nat., Bot., sér. 2 1: 302 (1834)

Species of this genus are pathogens or saprotrophs, mainly on woody hosts with a worldwide distribution (Philips et al. 2013). Currently, only 17 species have molecular data, therefore recollection, epitypification and molecular analysis is needed for this genus (Philips et al. 2013). Our strains clustered together with the type strain of D. seriata (Fig. 5).

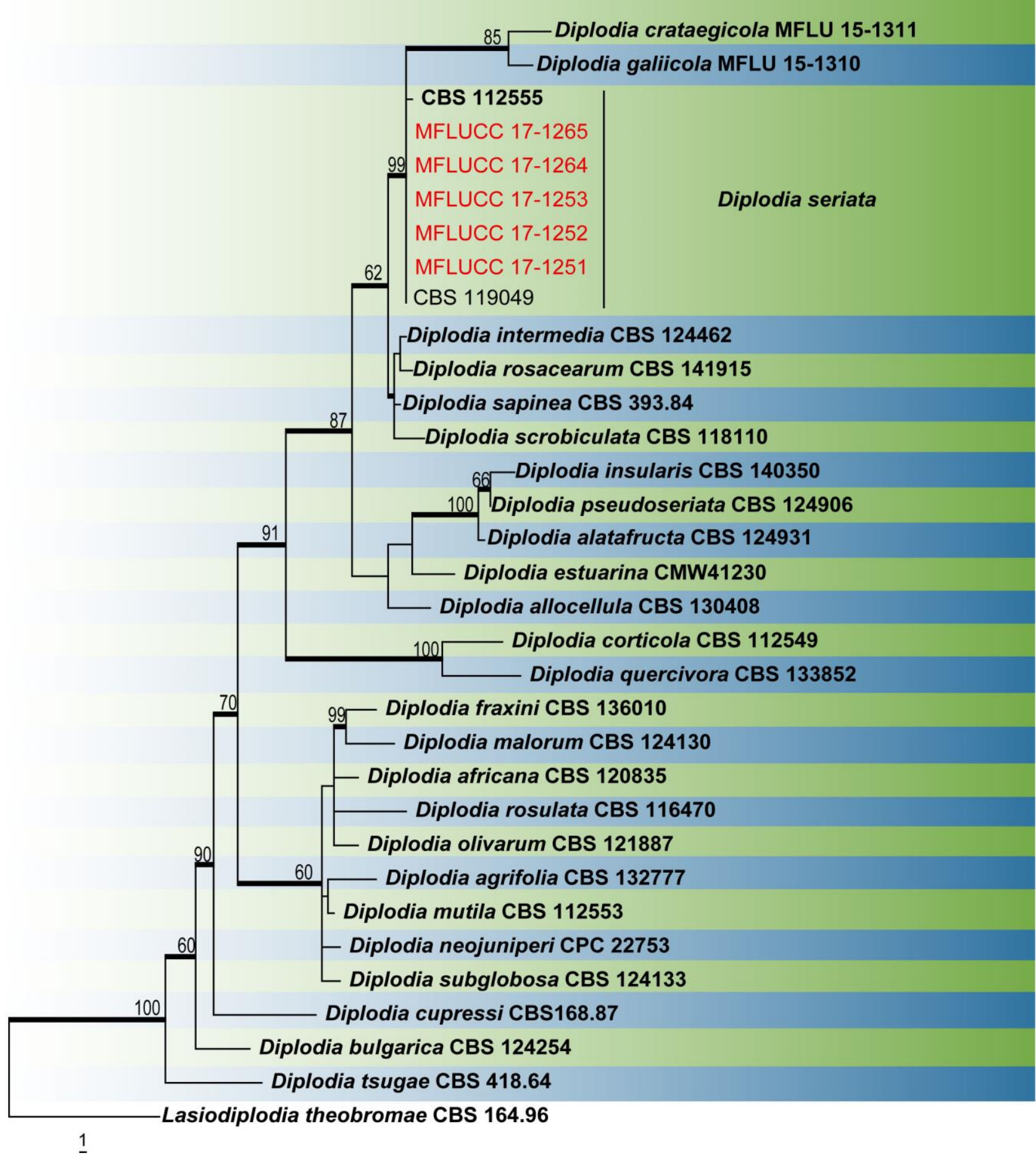

Fig. 5 - RAxML phylogram obtained from the combined ITS and TEF1 sequence data of Diplodia species. Ex-type strains are in bold. Strains isolated in this study are in red. RAxML bootstrap support (BS) values $\geq 50 \%$ are shown at the nodes and branches with Bayesian posterior probability scores $\geq 0.90$ given in bold. The tree is rooted with Lasiodiplodia theobromae CBS 164.96. 
Diplodia seriata De Not., Micr. Ital., Dec. 4: no. 6 (1842)

Facesoffungi number: FoF03596

Saprotrophic on dead and aerial branches of Vitis vinifera. Sexual morph: Not observed (see Philips et al. 2013 for description). Asexual morph: Conidiomata stromatic, separate or aggregated and confluent, immersed in the host, partially emergent at maturity, dark brown to black, ostiolate, apapillate, thick-walled, outer layers composed of dark brown textura angularis, inner layers of thin-walled hyaline. Conidiogenous cells 3-6×7-12 $\mu \mathrm{m}$, hyaline, thin-walled, smooth, cylindrical, swollen at the base, discrete, producing a single conidium at the tip, indeterminate, proliferating internally giving rise to periclinal thickenings or proliferating percurrently forming 2-3 annellations. Conidia $22-28 \times 11-15 \mu \mathrm{m}(\bar{x}=25 \times 12 \mu \mathrm{m}, \mathrm{n}=20)$, initially hyaline, becoming dark brown, moderately thick-walled, wall externally smooth, roughened on the inner surface, aseptate, ovoid, widest in the middle, apex obtuse, base truncate or rounded.

Culture characteristics - Colonies on PDA pale mouse grey to mouse grey, reverse dark mouse grey to fuscous black with sinuate edge, attaining $80 \mathrm{~mm}$ diam. in 7 days. Mycelium dark, septate, appressed to the medium surface.

Material examined - ITALY, Province of Forlì-Cesena, Trivella di Predappio, on dead and aerial branch of Vitis vinifera, 9 December 2015, Erio Camporesi IT 136 (MFLU 15-1081); culture, MFLUCC 17-1190, 17-1191; ITALY, Province of Forlì-Cesena, Trivella di Predappio, on dead and aerial branch of Vitis vinifera, 9 December 2015, Erio Camporesi IT 2726 (MFLU 16-0648); culture, MFLUCC 17-1251, 17-1252, 17-1253; ITALY, Province of Forlì-Cesena, Trivella di Predappio, on dead and aerial branch of Vitis vinifera, 9 December 2015, Erio Camporesi IT 2809 (MFLU 16-0514); culture, MFLUCC 17-1264, 17-1265.

Notes - Species of Diplodia are well-known to be associated with Botryosphaeria die back of grapevine worldwide. Diplodia seriata has been recorded as a saprobe or a weak secondary pathogen of grapevine (Úrbez-Torres et al. 2008). This species has also been recorded as a pathogen causing brown streaking of the wood and canker as well die back and "black dead arm" (Auger et al. 2004).

Dothiorella Sacc., Michelia 2(no. 6): 5 (1880)

Dothiorella was introduced by Saccardo (1880). Species of this genus are widely distributed on many host plants worldwide (Dissanayake et al. 2016). We provide an updated tree for Dothiorella (Fig. 7), where our strains cluster with Dothiorella iberica and D. sarmentorum.

Dothiorella iberica A.J.L. Phillips, J. Luque \& A. Alves, Mycologia 97(2): 524 (2005)

Facesoffungi number: FoF 03513

Saprotrophic on dead and aerial branches of Vitis vinifera. Sexual morph: Not observed. Asexual morph: Conidiomata up to $250 \mu \mathrm{m}$ high, $400 \mu \mathrm{m}$ diam., pycnidial, stromatic, solitary, globose, thick-walled, composed of dark brown thick-walled textura angularis, becoming thinwalled and hyaline towards the inner region. Conidiophores absent. Conidiogenous cells $8-15 \times 3-5$

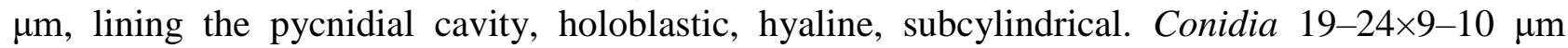
$(\bar{x}=22 \times 9 \mu \mathrm{m}, \mathrm{n}=30)$, initially hyaline, becoming dark brown and one-euseptate, often while still attached to the conidiogenous cell, ovoid with a broadly rounded apex and truncate base, brown walled, 1-septate, slightly constricted at the septum.

Culture characteristics - Colonies initially white to olivaceous buff, becoming greenish olivaceous from the middle of colonies within 7 days, iron-grey (surface) and black (reverse) with age, with suppressed, moderately fluffy mycelium, covering $90 \mathrm{~mm}$ diam Petri dishes after 4 days in the dark.

Material examined - ITALY, Province of Forlì-Cesena, Tessello - Cesena, on dead and aerial branch of Vitis vinifera, 5 March 2015, Erio Camporesi IT 2404 (MFLU 15-3513), culture, MFLUCC 17-0964. 
Notes - Dothiorella iberica has been widely isolated from Vitis vinifera world-wide and is a causal agent of Botryosphaeria die back (Phillips et al. 2013). This study provides the first report of $D$. iberica as a saprotroph on Vitis vinifera from Italy.
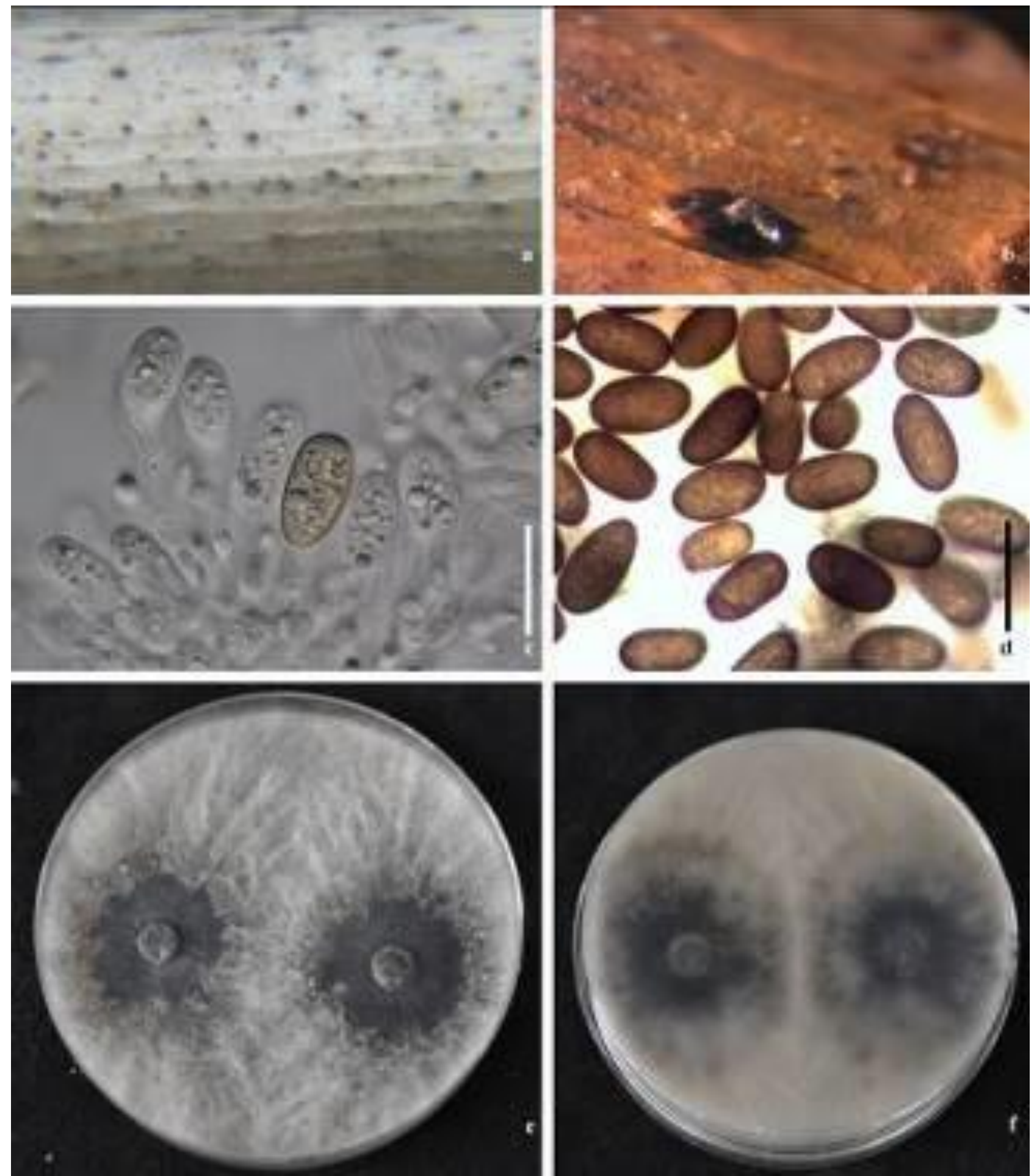

Fig. 6 - Diplodia seriata. a, b. Conidiomata on host tissue. c. Conidiogenous cells with developing conidia. d. Mature conidia. e. Upper view of 7 day old culture. f. Reverse view of 7 day old culture. Scale bars: c, $\mathrm{d}=20 \mu \mathrm{m}$.

Dothiorella sarmentorum (Fr.) A.J.L. Phillips, A. Alves \& J. Luque, Mycologia 97(2): 522 (2005) Facesoffungi number: FoF00171

Saprotrophic on dead and aerial branches and leaves of Vitis vinifera. Sexual morph: Not observed (see Phillips et al. 2013 for a description). Asexual morph: Conidiomata 300-440 $\mu \mathrm{m}$ 
high $\times 215-290 \mu \mathrm{m}$ diam. $(\bar{x}=376 \times 250 \mu \mathrm{m}, \mathrm{n}=5)$, stromatic, solitary or scattered in small groups, immersed, uniloculate, individual or aggregated, black, globose to subglobose, ostiolate. Conidiomatal wall comprising several layers; outer layers composed of thick-walled, dark brown, somewhat flattened cells of textura angularis and inner layers of larger, thin-walled, lightly pigmented or hyaline cells. Conidiophores reduced to conidiogenous cells. Conidiogenous cells 7$15 \times 3-5 \mu \mathrm{m} \quad(\bar{x}=10 \times 3 \mu \mathrm{m}, \mathrm{n}=15)$, lining the conidiomatal cavity, holoblastic, hyaline, subcylindrical, proliferating at the same level giving rise to periclinal thickenings. Conidia 18-23x 8-10 $\mu \mathrm{m}(\bar{x}=20 \times 9 \mu \mathrm{m}, \mathrm{n}=30)$, ovoid, with a broadly rounded apex and truncate base, initially hyaline to lightly pigmented and aseptate, becoming dark brown and 1-septate, slightly constricted at the septum, smooth-walled.

Culture characteristics - Colonies on PDA at $25^{\circ} \mathrm{C}$ attaining $80 \mathrm{~mm}$ diam in 5 days, circular, flat, moderately dense, surface initially white, becoming greenish olivaceous to greyish within 7 days, smooth surface with entire to slightly undulate edge.

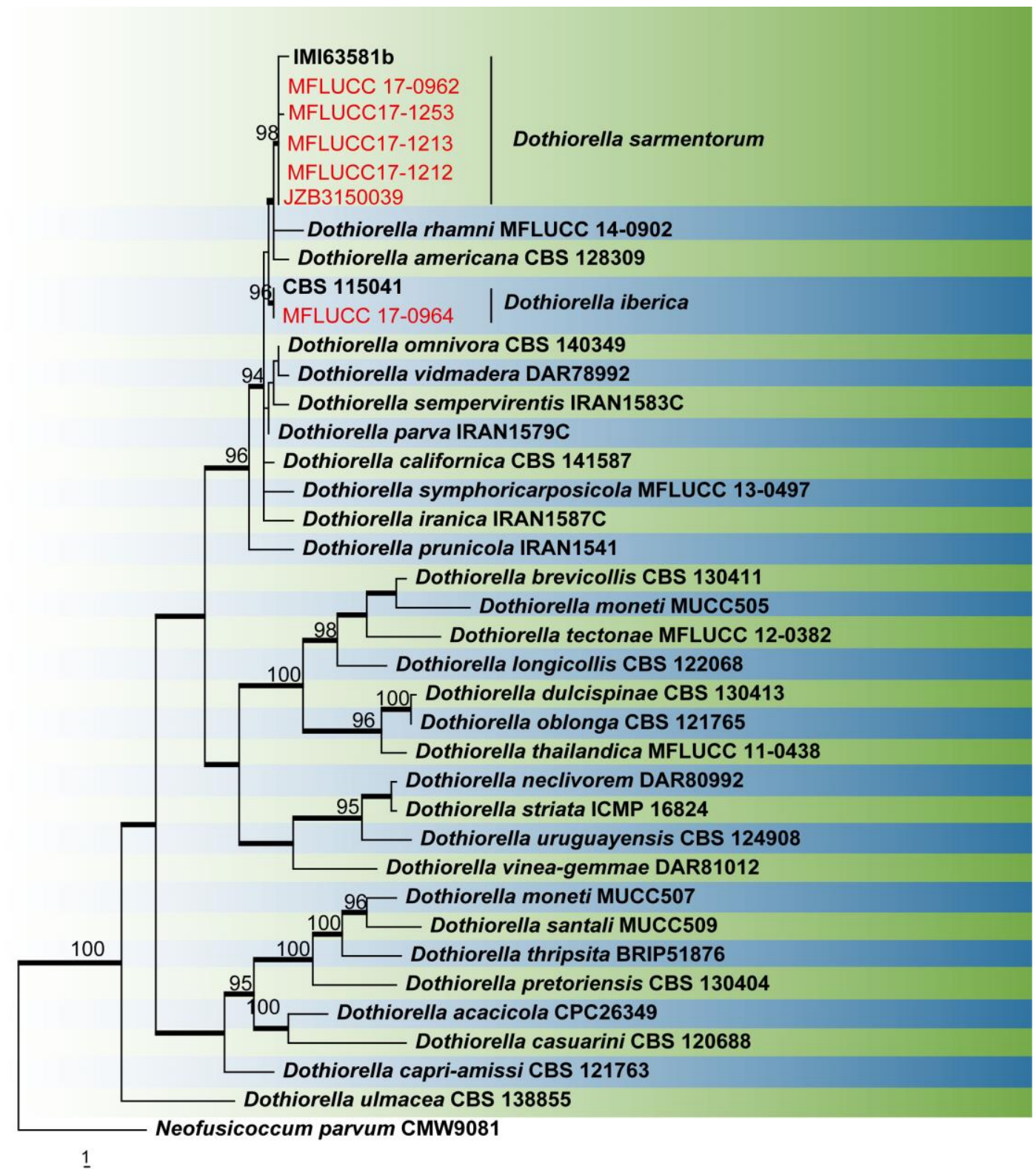

Fig. 7 - RAxML phylogram obtained from the combined ITS and TEF1 sequence data of Diplodia species. The ex-type strains are in bold. The strains isolated in this study are shown in red. RAxML bootstrap support (BS) values $\geq 50 \%$ are shown at the nodes and branches with Bayesian posterior probability scores $\geq 0.90$ are given in bold. The tree is rooted with Neofusicoccum parvum CMW 9081. 
Material examined - ITALY, Province of Forlì-Cesena, near Pieve di Rivoschio, on dead and aerial branch of Vitis vinifera, 2 February 2015, Erio Camporesi IT 2363 (MFLU 15-1082); culture, MFLUCC 17-1212, 17-1213, 17-1253; ITALY, Province of Forlì-Cesena, Teodorano Meldola, on dead and aerial branch of Vitis vinifera, 21 February 2015, Erio Camporesi IT 2386 (MFLU 15-3510); culture, MFLUCC 17-0962; CHINA, Beijing, on dead attached leaf of Vitis vinifera, 3 June 2015, Ruvishika S. Jayawardena, culture JZB3150039.

Notes - According to the combined phylogenetic analysis of ITS and TEF gene regions, the isolates obtained from $V$. vinifera in this study are recognized as D. sarmentorum. Dothiorella sarmentorum has a world-wide distribution (Dissanayake et al. 2016) and reported to be a major pathogen in grapevine trunk diseases (Pitt et al. 2013).
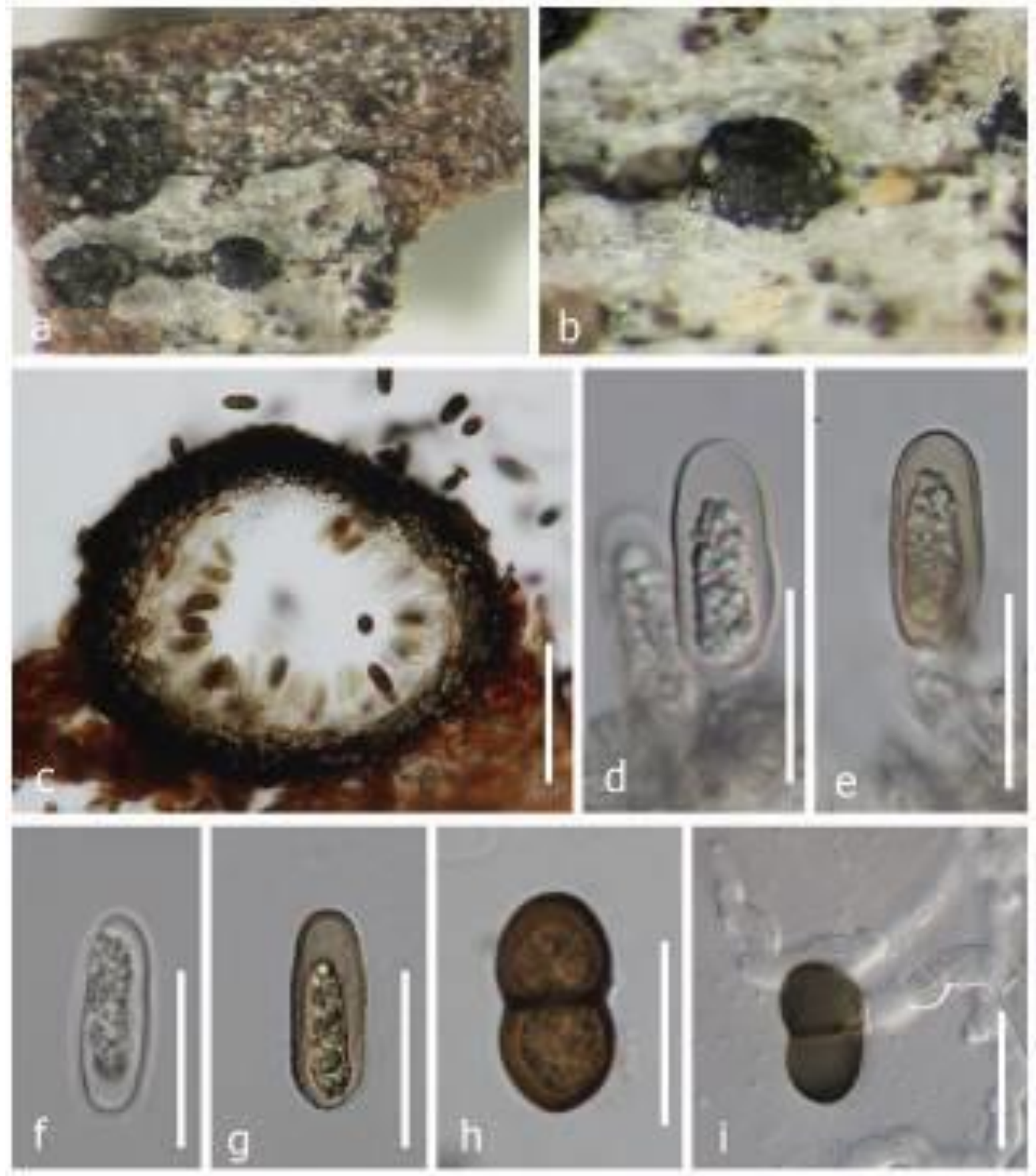

Fig. 8 - Dothiorella iberica. a, b. Conidiomata immersed on host surface. c. Longitudinal section of a conidioma. d, e. Conidiogenous cells with developing conidia. f. Immature conidium. g, h. Mature conidia. i. Germinating conidium. Scale bars: $c=100 \mu \mathrm{m}, \mathrm{d}-\mathrm{i}=20 \mu \mathrm{m}$. 

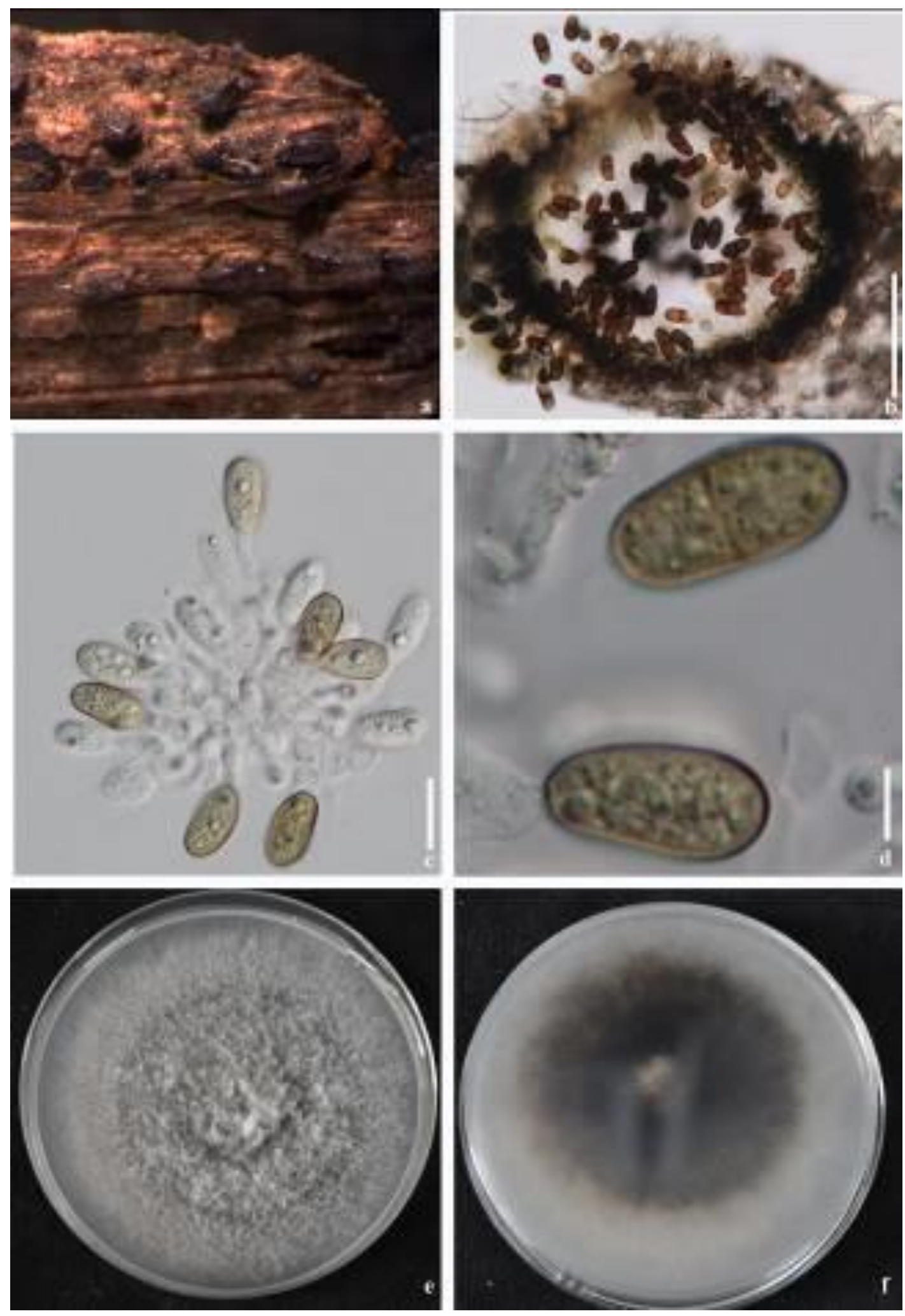

Fig. 9 - Dothiorella sarmentorum. a. Conidiomata immersed on host surface. b. Section of a conidioma. c. Conidiogenous cells with developing conidia. d. Mature conidia. Scale bars: $b=100$ $\mu \mathrm{m}, \mathrm{c}-\mathrm{d}=20 \mu \mathrm{m}$.

Neofusicoccum Crous, Slippers \& A.J.L. Phillips, Stud. Mycol. 55: 247 (2006)

Neofusicoccum is morphologically similar to Botryosphaeria. Therefore, morphological characters cannot be used to distinguish these two genera (Philips et al. 2013). In an updated tree for Neofusicoccum, our strains cluster with Neofusicoccum italicum and N. parvum (Fig. 10). 


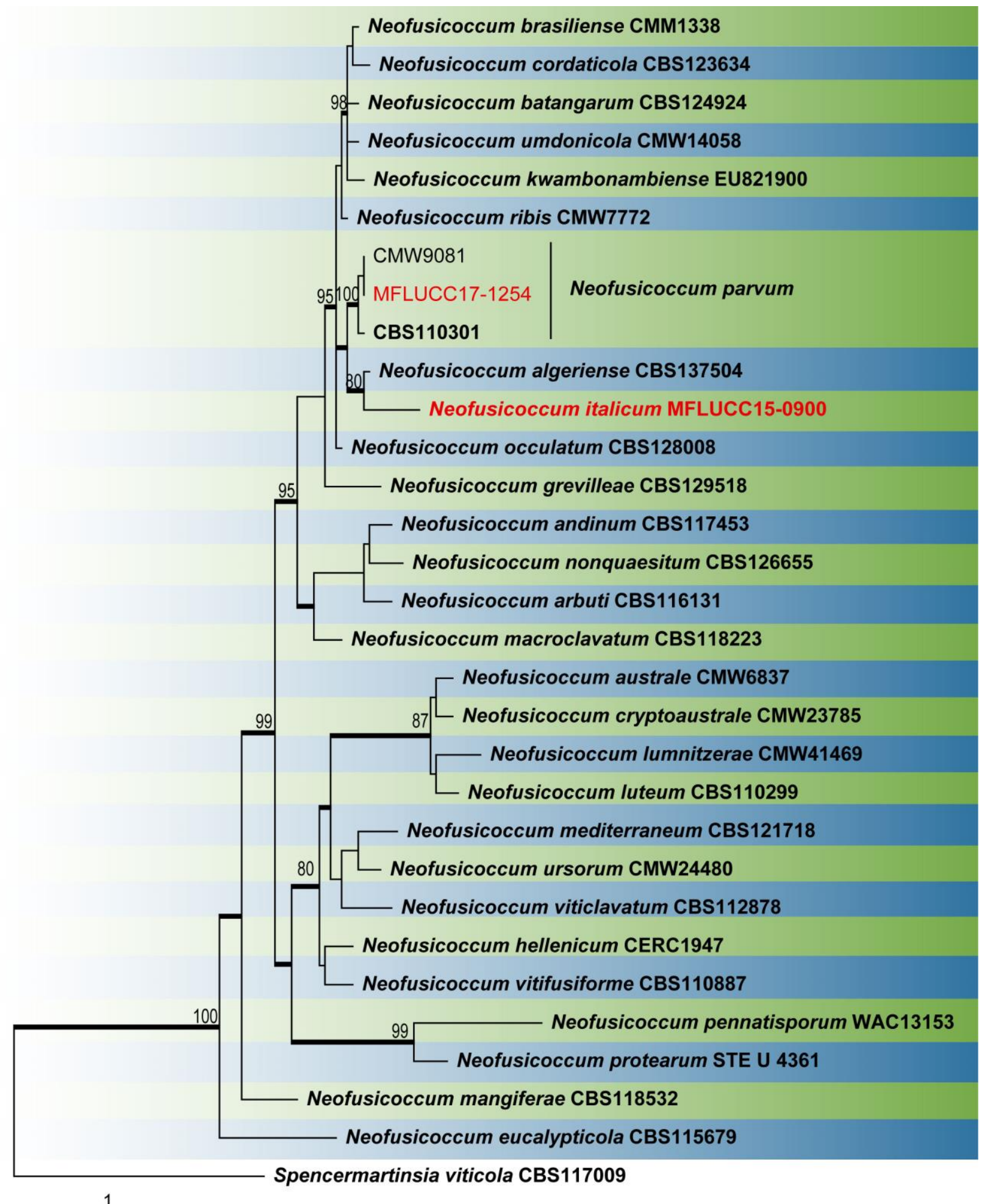

Fig. 10 - RAxML phylogram obtained from the combined ITS and TEF1 sequence data of Neofusicoccum species. The ex-type strains are in bold. The strains isolated in this study are shown in red. RAxML bootstrap support (BS) values $\geq 50 \%$ are shown at the nodes and branches with Bayesian posterior probability scores $\geq 0.90$ are given in bold. The tree is rooted with Spencermartinsia viticola CBS 117009.

Neofusicoccum italicum Dissan. \& K.D. Hyde, in Marin-Felix et al., Stud. Mycol. 86: 170 (2017)

Facesoffungi number: FoF03820

See Marin-Felix et al. (2017) for the description of this species. 
Material examined - ITALY, Province of Forlì-Cesena, Farazzano - Forlì, on dead land branch of Vitis vinifera, 10 November 2016, Erio Camporesi IT 117 (MFLU 16-2872); culture, MFLUCC 15-0900.

Notes - This species have been recorded only on Vitis vinifera from Italy and is a saprotroph (Marin-Felix et al. 2017).
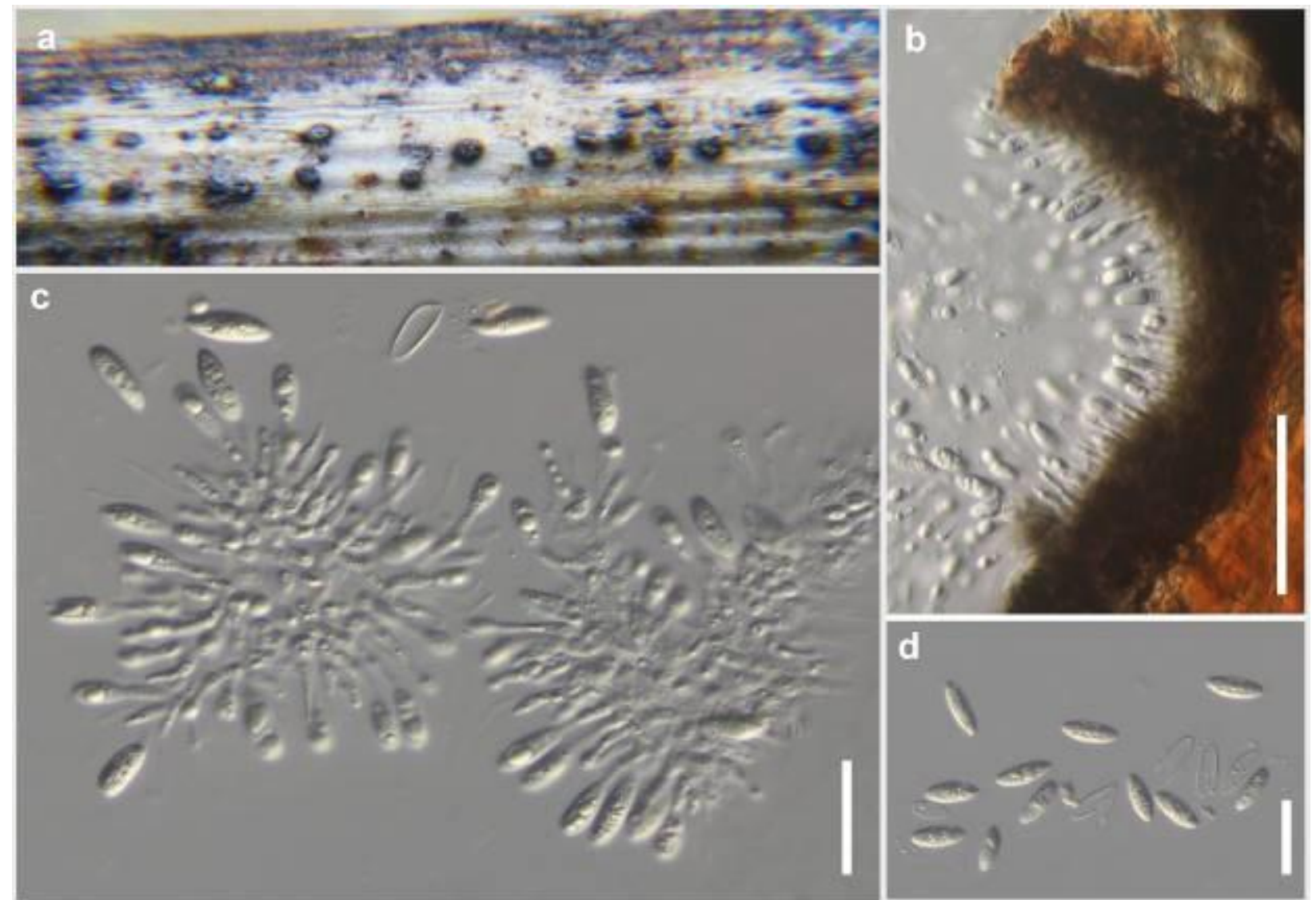

Fig. 11 - Neofusicoccum italicum a. Conidiomata on host substrate. b. Cross section of conidioma. c. Immature and mature conidia attached to conidiogenous cells. d. Mature conidia. Scale bars: $\mathrm{b}=100 \mu \mathrm{m}, \mathrm{c}-\mathrm{d}=20 \mu \mathrm{m}$.

Neofusicoccum parvum (Pennycook \& Samuels) Crous, Slippers \& A.J.L. Phillips, in Crous, Slippers, Wingfield, Rheeder, Marasas, Phillips, Alves, Burgess, Barber \& Groenewald, Stud. Mycol. 55: 248 (2006)

\section{Facesoffungi number: FoF02411}

Saprotrophic on dead and aerial branches of Vitis vinifera. Sexual morph: Not observed (see Philips et al. 2013 for a description). Asexual morph: Conidiomata 210-290 $\mu \mathrm{m}$ diam., globose and apapillate to pyriform with a short, acute papilla, entire locule lined with conidiogenous cells. Conidiogenous cells $7-25 \times 2-4 \mu \mathrm{m}(\bar{x}=15 \times 3 \mu \mathrm{m}, \mathrm{n}=20)$, holoblastic, hyaline, subcylindrical, proliferating percurrently to form 1-2 annellations, or proliferating at the same level to form periclinal thickenings. Conidia $12-23 \times 4-6 \mu \mathrm{m}(\bar{x}=15 \times 3 \mu \mathrm{m}, \mathrm{n}=30)$, ellipsoidal with apex round and base flat, unicellular, hyaline, old conidia becoming 1-2-septate, hyaline, or light brown with the middle cell darker than the end cells.

Cultural characteristics - Colonies on PDA reaching $80 \mathrm{~mm}$ diam. in 5 days at $25^{\circ} \mathrm{C}$. Mycelium white, flat and dense, becoming light iron-grey after 14 days, with entire margin with slightly undulate edge.

Material examined - ITALY, Province of Forlì-Cesena, Trivella di Predappio, on dead and aerial branch of Vitis vinifera, 9 December 2015, Erio Camporesi IT 2726 (MFLU 16-0648); culture, MFLUCC 17-1254. 
Notes - Neofusicoccum parvum has a wide host range and a wide distribution. This species is an important pathogen of grapevine causing Botryosphaeria die back in many grape growing regions in the world (Philips et al. 2013).
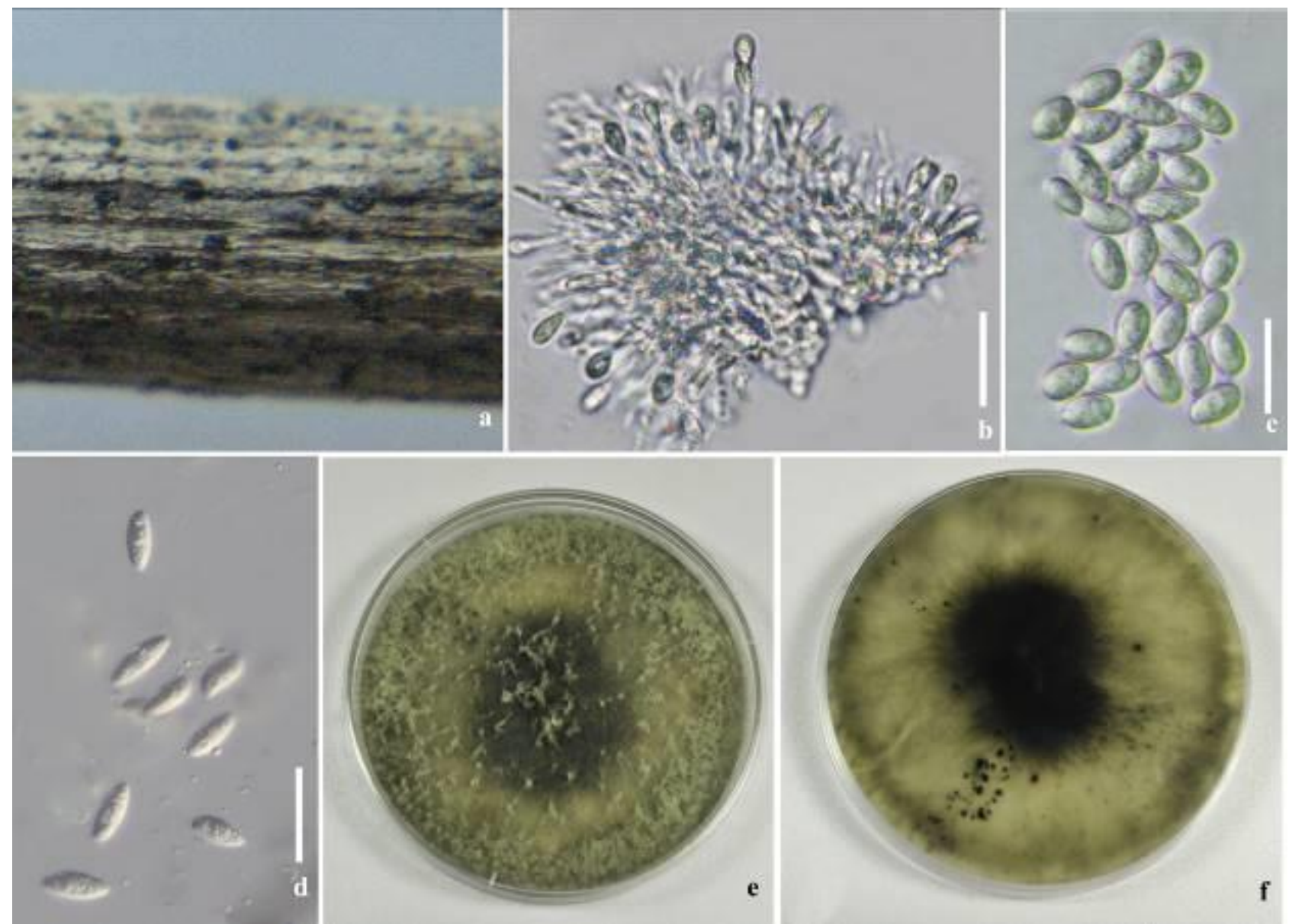

Fig. 12 - Neofusicoccum parvum. a. Conidiomata on host. b. Conidiogenous cells. c-d. Conidia. e. Surface view of the colony. $f$. Reverse view of the colony. Scale bars: $b-d=10 \mu \mathrm{m}$.

Capnodiales Woron., Annls mycol. 23(1/2): 177 (1925)

Cladosporiaceae Nann., Repert. mic. uomo: 404 (1934)

This family is homotypic with the genus Cladosporium, including holomorphs with asexual hyphomycetous and their sexual "davidiella" states (Hyde et al. 2013).

Cladosporium Link, Mag. Gesell. naturf. Freunde, Berlin 7: 37 (1816) [1815]

Cladosporium is one of the largest genera of dematiaceous hyphomycetes (Bensch et al. 2015). Members of this genus are characterized by a unique coronate structure of the conidiogenous loci and conidial hila, consisting of a central convex dome surrounded by a raised periclinal rim (Bensch et al. 2015). Species are saprotrophs, endophytes, animal, human and plant pathogens, worldwide (Seifert et al. 2011). Our strains cluster with Cladosporium cucumerinum and C. cladosporioides (Fig. 13).

Cladosporium cladosporioides (Fresen.) G.A. de Vries, Contrib. Knowledge of the Genus Cladosporium Link ex Fries: 57 (1952)

Faces of fungi number: FoF 03131

Saprotrophic on dead and aerial branches and roots of Vitis vinifera. Sexual morph: Not observed. Asexual morph: Conidiophores solitary, macronematous, arising terminally from ascending hyphae, cylindrical-oblong, 40-300×3-6 $\mu \mathrm{m}$. Conidiogenous cells integrated, usually terminal, cylindrical-oblong, $40 \mu \mathrm{m}$ long, with up to four loci crowded at the apex. Ramoconidia 


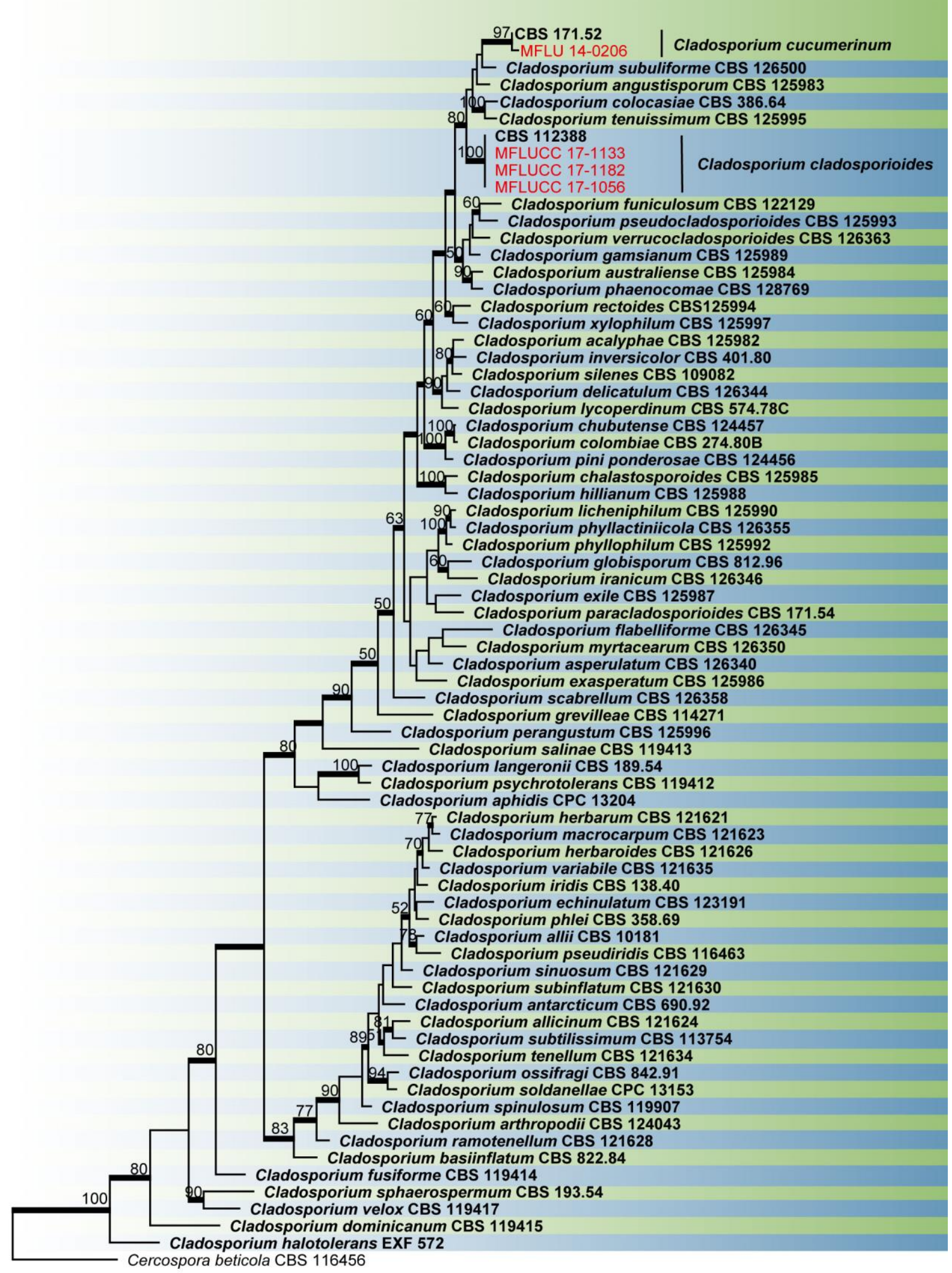

10

Fig. 13 - One of the ten most parsimonious trees obtained from a heuristic search of combined ITS, LSU and ACT sequence data of taxa from the Cladosporium. Parsimony bootstrap support values $\geq$ $75 \%$ are indicated at the nodes and branches with Bayesian posterior probabilities $\geq 0.90$ given in bold. The ex-type strains are in bold. The strains isolated in this study are shown in red. The tree is rooted with Cercospora beticola CBS 116456. 
seceding at one of the upper, somewhat darkened septa, straight to slightly curved, cylindrical-

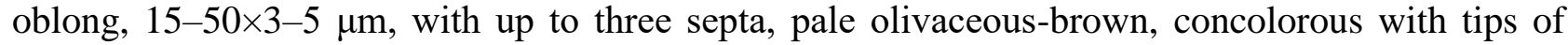
conidiophores, smooth, base $2.5-4 \mu \mathrm{m}$ wide, unthickened or slightly thickened, sometimes slightly refractive. Conidia numerous, catenate in long branched chains, small terminal conidia subglobose, obovoid or ovoid, aseptate, intercalary conidia limoniform, ellipsoid, 5-12×2-3 $\mu \mathrm{m}(\bar{x}=7 \times 3$, $\mathrm{n}=40$ ).

Culture characteristics - Colonies on PDA reach 3-5 cm diam., after 5 days at $25{ }^{\circ} \mathrm{C}$ greyolivaceous to dull green, margin regular, black, reverse black, with white feather margin.

Material examined - ITALY, Province of Forlì-Cesena, near Meldola, on dead and aerial branch of Vitis vinifera, 28 January 2016, Erio Camporesi IT 2809, (MFLU 16-0514), culture: MFLUCC 17-1056; CHINA, Beijing, on dead shoot of V. vinifera cv. Red Globe, 3 June 2015, Ruvishika S. Jayawardena, culture MFLUCC 17-1113; CHINA, Yunnan, on dead root of $V$. vinifera cv. CarbanateGernischet, 11 June 2015, X.H. Li, culture: MFLUCC 17-1182.

Notes - Cladosporium cladosporioides is known as a saprotroph as well as a secondary invader on grapevine (Bensch et al. 2010). This species has been isolated as a pathogen causing fruit rots, as an endophyte and a saprotroph of Vitis sp.

Cladosporium cucumerinum Ellis \& Arthur, Bull. Indiana Agric. Stat. 19: 9 (1889)

Faces of fungi number: FoF03823

Saprotrophic on dead and aerial branch of Vitis vinifera. Sexual morph: Not observed. Asexual morph: Conidiomata superficial, partly immersed on the substrate, composed of septate, branched, smooth, thin-walled, subhyaline to light brown hyphae. Conidiophores 150-256×8-11 $\mu \mathrm{m}$ diam $(\bar{x}=189 \times 10 \mu \mathrm{m}, \mathrm{n}=100)$, macronematous, subhyaline to light brown, thin-walled, smooth, 0-1-septate, unbranched, straight or flexuous, cylindrical. Conidiogenous cells $10-16 \times 6-7 \mu \mathrm{m}$ $(\bar{x}=11 \times 6 \mu \mathrm{m}, \mathrm{n}=100)$, holoblastic, monoblastic, integrated, terminal, determinate, cylindrical to sublate, hyaline to subhyaline, rough. Conidia $28-52 \times 4-6 \mu \mathrm{m}(\bar{x}=45 \times 5 \mu \mathrm{m}, \mathrm{n}=100)$, acrogenous, enteroblastic, phialidic, hyaline to subhyaline, $0-1$-septate, subglobose, clavate, rough, thin-walled.

Material examined - ITALY, Province of Forlì-Cesena, Farazzano, on dead and aerial branch of Vitis vinifera, 30 January 2014, Erio Camporesi, IT 1690 (MFLU 14-0206).

Notes - Cladosporium cucumerinum is a well known pathogen causing scab disease of cucumber (Ogorek et al. 2012). This study provides the first record of this species as a saprotroph on Vitis vinifera.

Mycosphaerellaceae Lindau, in Engler \& Prantl, Nat. Pflanzenfam., Teil. I (Leipzig) 1(1): 421 (1897)

This family is recognized by having characteristic pseudothecial ascomata that are superficial or immersed (Hyde et al. 2013). Several studies have shown that Mycosphaerellaceae is polyphyletic (Videira et al. 2017). Videira et al. (2017) resolved the phylogenetic relationships among the genera currently recognized within this family based on morphology and multigene phylogeny.

Pseudocercospora Speg., Anal. Mus. nac. B. Aires, Ser. 3 13: 437 (1911)

This is the second largest cercosporoid genus. Many species are plant pathogens, while some are endophytes or saprotrophs (de Breeyen et al. 2006). Pseudocercospora is a large cosmopolitan genus that is commonly associated with leaf spots and blights on a wide range of plant hosts. Species occur in a wide range of climates (Videira et al. 2017). Phylogenetic placement of this genus is well-established within the family Mycosphaerellaceae (Crous et al. 2013, Videira et al. 2017). Strains isolated in this study clustered with the reference specimen of $P$. vitis with high bootstrap support (Fig. 16). 

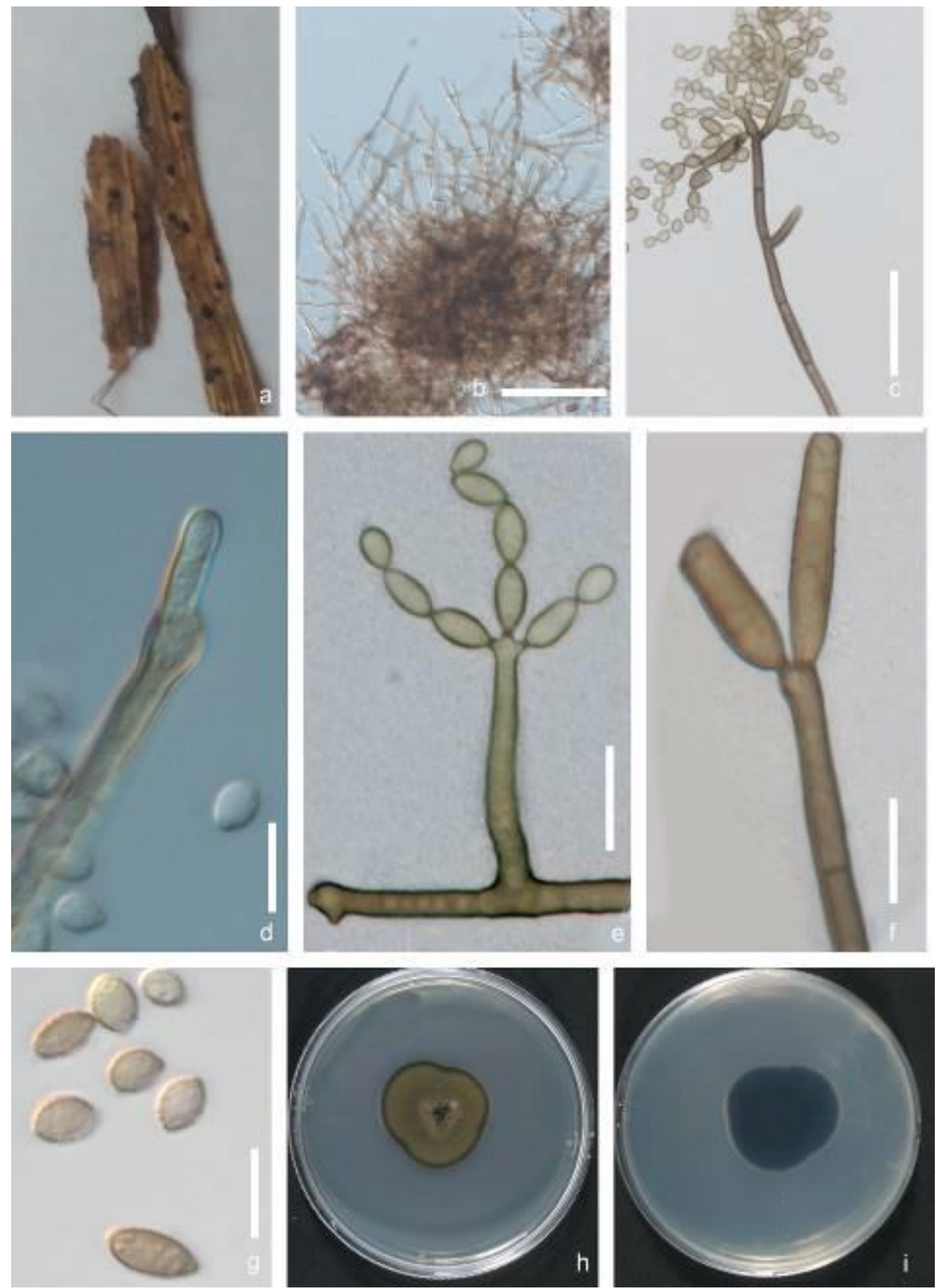

Fig. 14 - Cladosporium cladosporioides. a. Fruiting bodies on host tissue. b. Conidiomata. c-e. Macro- and micronematous conidiophores and conidia chains. f. Secondary ramoconidia. g. Conidia. h. Upper view of colony. $i$. Reverse view of colony. Scale bars: $b-c, e-f=50 \mu \mathrm{m}, \mathrm{d}-\mathrm{g}=10$ $\mu \mathrm{m}$. 

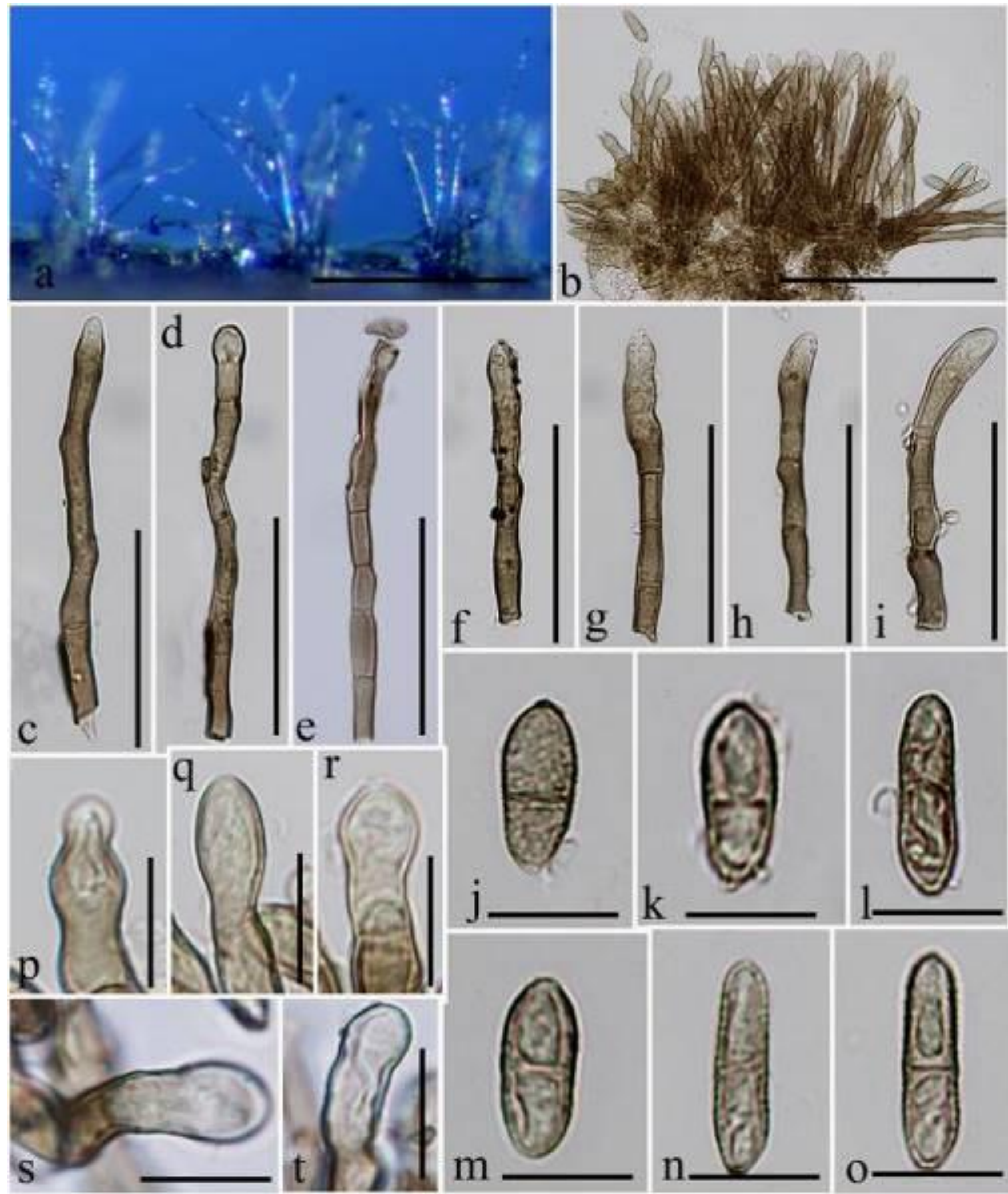

Fig. 15 - Cladosporium cucumerinum. a. Colonies on host tissue. b. Conidioma. c-f. Conidiophores. f-i. Conidiophores with conidiogenous cells. j-o. Conidia. p-t. Conidiogenous cells. Scale bars: $\mathrm{a}-\mathrm{b}=500 \mu \mathrm{m}, \mathrm{c}-\mathrm{i}=100 \mu \mathrm{m}, \mathrm{j}-\mathrm{t}=50 \mu \mathrm{m}$. 


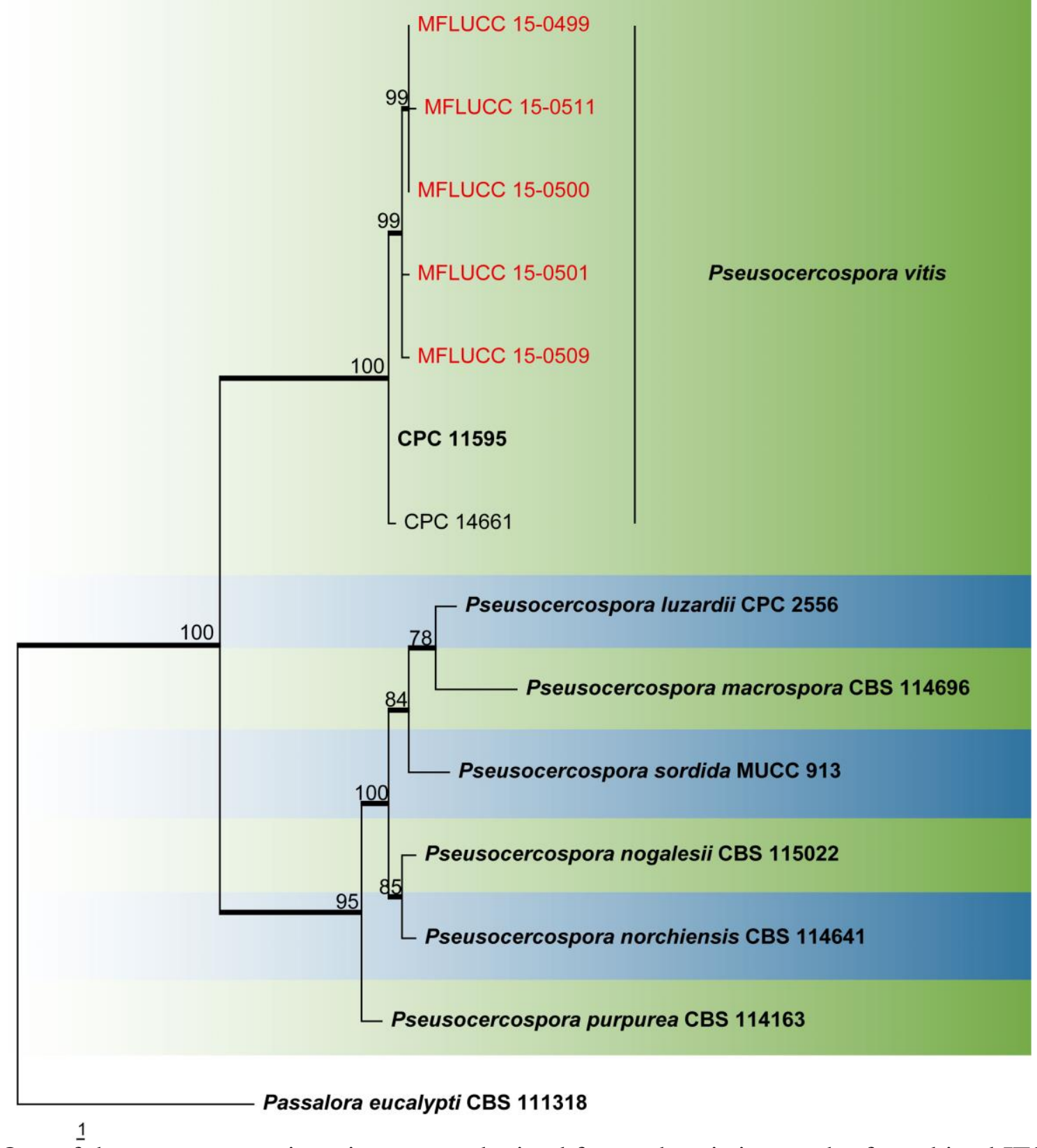

Fig. 16 - One of the ten most parsimonious trees obtained from a heuristic search of combined ITS and ACT sequence data of taxa of Pseudocercospora. Parsimony bootstrap support values $\geq 50 \%$ are indicated at the nodes and branches with Bayesian posterior probabilities $\geq 0.90$ are given in bold. The ex-type strains are in bold. Strains obtained in this study are in blue. The tree is rooted with Pseudocercospora eucalypti CBS 111318.

Pseudocercospora vitis (Lév.) Speg., Anal. Mus. nac. B. Aires, Ser. 3 13: 438 (1911)

Facesoffungi number: FoF03597

Pathogen on leaves of Vitis sp. Sexual morph: Not observed. Asexual morph: Conidiophores $93-267 \times 2-5 \mu \mathrm{m}(\bar{x}=165 \times 4 \mu \mathrm{m}, \mathrm{n}=30)$, synnematous, brown, smooth, unbranched, straight to curved, sub-cylindrical. Conidiogenous cells up to $32 \mu \mathrm{m}$ long, terminal, brown, smooth, proliferating sympodially. Conidia $17-45 \times 3-8 \mu \mathrm{m}(\bar{x}=31 \times 5 \mu \mathrm{m}, \mathrm{n}=30)$, solitary, simple, pale to mild brown, smooth or rugulose, obclavate, apex subobtuse, base obconically truncate, straight to gently curved, 2-6-septate. 

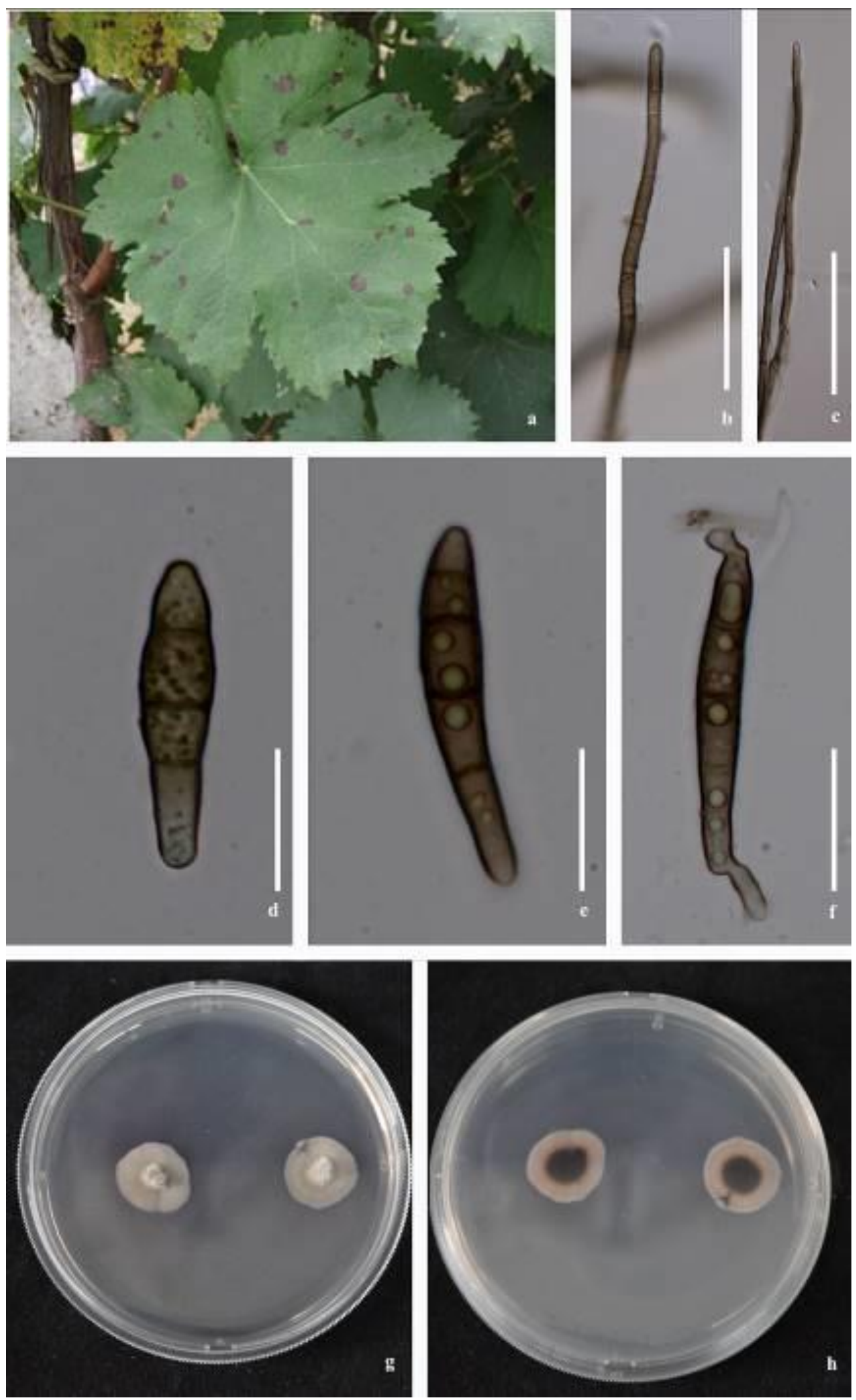

Fig. 17 - Pseudocercospora vitis. a. Lesions on Vitis sp. b-c. Conidiophores. d-f. Conidia. g. Upper view of colony after 14 days. h. Reverse view of colony after 14days. Scale bars: $b-c=20 \mu \mathrm{m}, d-$ $\mathrm{f}=10 \mu \mathrm{m}$.

Cultural characteristics - Colonies on PDA reaching $40 \mathrm{~mm}$ diam. after 18 days at $25^{\circ} \mathrm{C}$, with undulate edge, effuse, tufted, centre greyish white becoming olivaceous brown with age, dull green towards the edge, reverse dull green. 
Material examined - THAILAND, Chiang Sean, on leaves of Vitis sp., 7 March 2015, Ruvishika S. Jayawardena LCS04, LCS01, LSC02 (MFLU 15-0684, 15-0682, 15-0681); living culture, MFLUCC 15-0499, 15-0500 and 15-0501; THAILAND, Golden Triangle, Chiang Sean, on leaves of Vitis sp., 7 March 2015, K.C. Mallikarathna LGT03, LGT04 (MFLU 15-0669, 15-0668); living culture, MFLUCC 15-0511 and 15-0509.

Notes - Pseudocercospra vitis is a pathogen of Vitis sp. causing leaf spots. This species appears to be host-specific (Crous et al. 2013). Pseudocercospora riachueli var. horiana (Togashi \& Katsuki) U. Braun \& Crous has been recorded from Thailand, but $P$. vitis was not recorded (Pheng et al. 2013). Therefore, this study provides the first report of $P$. vitis associated with Vitis sp. in Thailand.

Dothideales Lindau, in Engler \& Prantl, Nat. Pflanzenfam., Teil. I (Leipzig) 1(1): 373 (1897)

Saccotheciaceae Bonord., Abh. naturforsch. Ges. Halle 8: 82 (1864)

Species of this family are parasitic or saprobic. This family can be distinguished by having immersed to erumpent, uniloculate ascostromata and aseptate to many-septate hyaline ascospores (Thambugala et al. 2014).

Aureobasidium Viala \& G. Boyer, Rev. gén. Bot. 3: 371 (1891)

This genus was introduced by Viala and Boyer (1891). Species of this genus are known to be pathogens and saprotrophs (Thambugala et al. 2014). Thambugala et al. (2014) placed this genus in the Aureobasidiaceae. Liu et al. (2015) synonymized this family under Saccotheciaceae. Strains isolated in this study clustered together with the type strain of Aureobasidium pullulans (Fig. 18).

Aureobasidium pullulans (de Bary) G. Arnaud var. pullulans, Annales École Nat. Agric. Montpellier 16: 39, 1918

Facesoffungi number: FoF00099

Saprotrophic on dead and aerial branches of Vitis vinifera. Sexual morph: not observed. Asexual morph: Conidiomata acervular to sporodochial, amphigenous, substomatal, subepidermal, pulvinate, dry or crystalline in appearance, pale brown, discrete. Conidiogenous cells undifferentiated, intercalary or terminal on hyaline hyphae or arising as short lateral branches. Conidia 8-16 $\times 4-7 \mu \mathrm{m}(\bar{x}=10 \times 5 \mu \mathrm{m}, \mathrm{n}=40)$, blastic, hyaline, smooth-walled, aseptate, straight, ellipsoidal to sphaerical, reniform to sickle-shaped, sometimes cylindrical with obtuse ends and occasionally with a slightly truncate base, rather variable in shape and size.

Culture characteristics - Colonies on PDA attaining 30mm diam. at $25^{\circ} \mathrm{C}$ after $7 \mathrm{~d}$ appearing smooth and slimy due to abundant sporulation. No aerial mycelium. Pink to yellow culture, yellow to light yellow in reverse view. After 14days black sectors composed of dark pigmented hyphae.

Material examined - ITALY, Province of Forlì-Cesena, Teodorano - Meldola, on dead and aerial branch of Vitis vinifera, 15 February 2015, Erio Camporesi IT 2378 (MFLU 15-1084); culture, MFLUCC 17-1218; ITALY, Province of Forlì-Cesena, Teodorano - Meldola, on dead and aerial branch of Vitis vinifera, 16 February 2015, Erio Camporesi IT 2382 (MFLU 15-1086); living culture, MFLUCC 17-1221, MFLUCC 17-1222; ITALY, Province of Forlì-Cesena, near Meldola, on dead and aerial branch of Vitis vinifera, 2 February 2016, Erio Camporesi IT 2800 (MFLU 160652) culture, MFLUCC 17-1256; ITALY, Province of Forlì-Cesena, Tessello - Cesena, on dead and aerial branch of Vitis vinifera, 5 March 2015, Erio Camporesi IT 2404 (MFLU 15-3513), culture, MFLUCC 17-1231; ITALY, Province of Forlì-Cesena, Farazzano - Forlì, on dead and aerial branch of Vitis vinifera, 10 November 2016, Erio Camporesi IT 3146 (MFLU 16-2813).

Notes - Isolates found in this study are morphologically similar to the type species of $A$. pullulans and phylogenetic analysis of combined LSU, SSU and ITS gene regions clustered them with A. pullulans (Fig.17). Aureobasidium pullulans has been recorded as an endophyte on Vitis sp. (Mulenko et al. 2008, Gonzalez \& Tello 2011, Sanoamuang et al. 2013, Fischer et al. 2016). This study provides the first record of this species as a saprotroph on $V$. vinifera in Italy. 


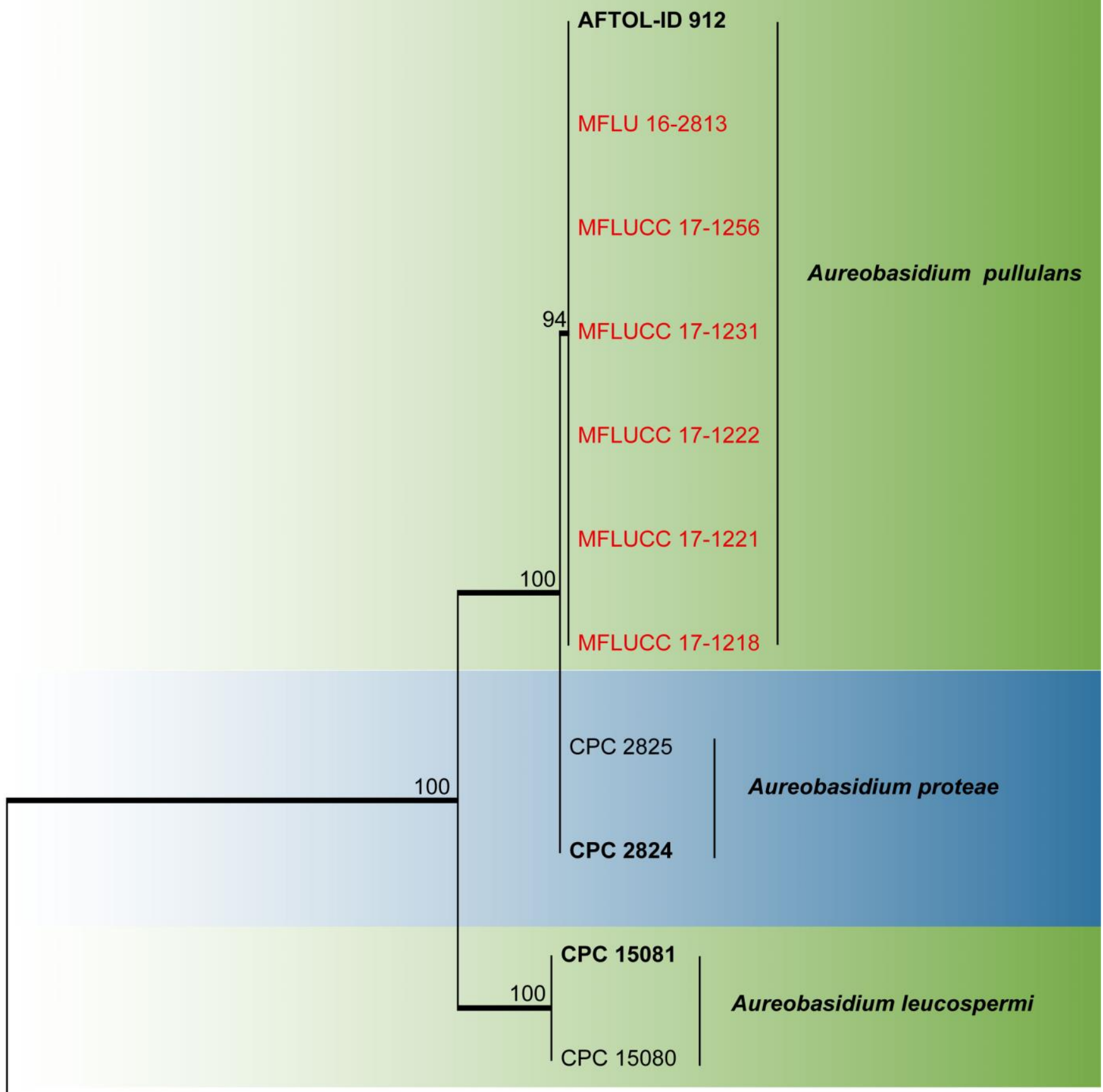

Celosporium larixicola L3-1

$-1$

Fig. 18 - One of ten most parsimonious trees obtained from a heuristic search of combined LSU, SSU and ITS sequence data of taxa of Aureobasidium. Parsimony bootstrap support values $\geq 50 \%$ are indicated at the nodes and branches with Bayesian posterior probabilities $\geq 0.90$ given in bold. Ex-type strains are in bold. Strains obtained in this study are in red. The tree is rooted with Celosporium larixicola L3-1. 

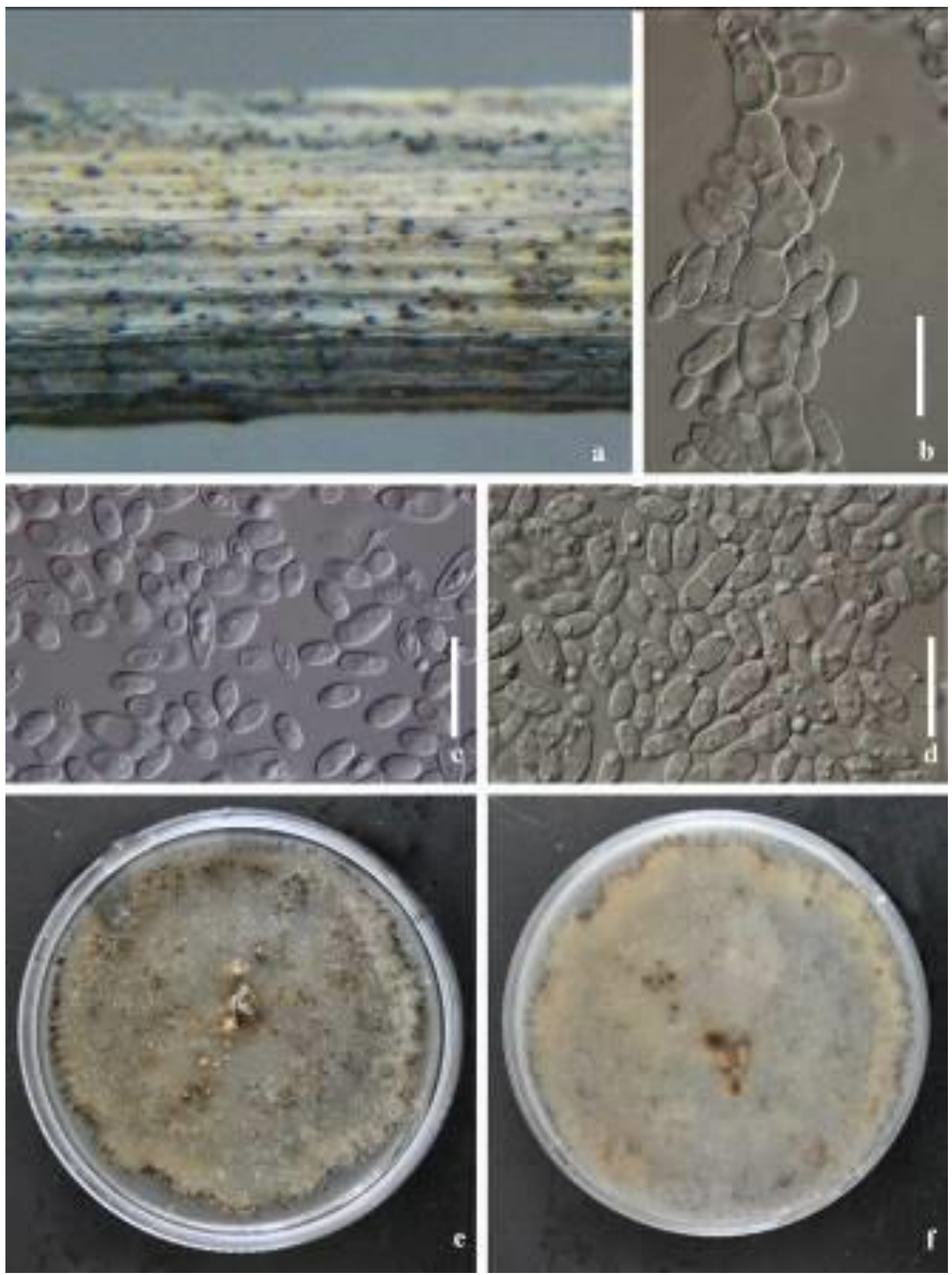

Fig. 19 - Aureobasidium pullulans. a. Fruiting bodies on host tissue. b. Conidiophore and conidiogenesis. c-d. Conidia. e. Surface view of colony after 7 weeks. f. Reverse view of colony after 7 weeks. Scale bars: $b-d=10 \mu \mathrm{m}$.

Pleosporales Luttr. ex M.E. Barr, Prodr. Cl. Loculoasc. (Amherst): 67 (1987)

Amorosiaceae Thambugala \& K.D. Hyde, in Thambugala et al., Fungal Diversity: 10.1007/s13225015-0348-3, [54] (2015)

Amorosiaceae was introduced by Thambugala et al. (2015). This family is characterized by hyphomycetous asexual morphs and appears to grow within ascomata of other ascomycetes (Thambugala et al. 2015). Currently this family comprises two genera. An updated family tree is 
provided in Hyde et al. (2017), while in this paper a tree to show the placement of our isolates is given (Fig. 20).

Angustimassarina Thambug., Kaz. Tanaka \& K.D. Hyde, in Thambugala et al., Fungal Diversity: 10.1007/s13225-015-0348-3, [55] (2015)

Species of this genus are considered to be mainly fungicolous and appear to grow within ascomata of other ascomycetes. Currently there are eight species in the genus (Index Fungorum, 2018).

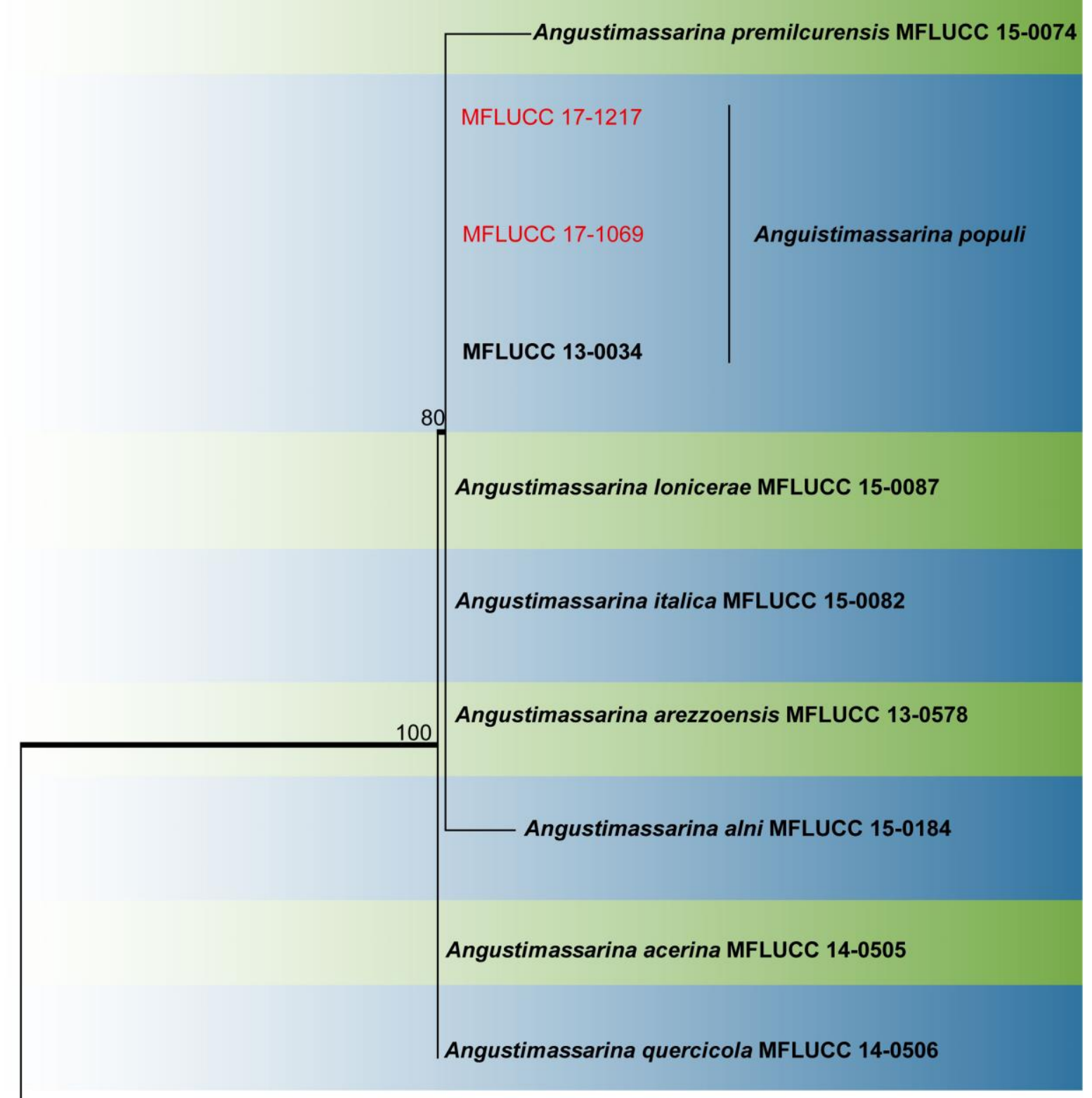

Amorosia littoralis NN6654

Fig. 20 - One of the eight most parsimonious trees obtained from a heuristic search of combined ITS, LSU, SSU and TEF1 sequence data of taxa from the Angustimassarina. Parsimony bootstrap support values $\geq 50 \%$ are indicated at the nodes and branches with Bayesian posterior probabilities $\geq 0.90$ are given in bold. Ex-type strains are in bold. Strains obtained in this study are in red. The tree is rooted with Amorosia littoralis NN 6654n. 
Angustimassarina populi Thambug. \& K.D. Hyde, in Thambugala et al., Fungal Diversity: 10.1007/s13225-015-0348-3, [56] (2015)

Facesoffungi number: FoF01086

Saprotrophic on dead and aerial branches of Vitis vinifera. Sexual morph: Ascomata 150$170 \mu \mathrm{m}$ high, $110-120 \mu \mathrm{m}(\bar{x}=160 \times 138 \mu \mathrm{m}, \mathrm{n}=10)$ diam., solitary, immersed, becoming erumpent, coriaceous, black, globose to subglobose, uniloculate, ostiolate. Ostiole crest-like, rounded, papillate, with a pore-like opening. Peridium $13-30 \mu \mathrm{m}(\bar{x}=21 \mu \mathrm{m}, \mathrm{n}=10)$ wide, composed of dark brown to hyaline cells of textura angularis. Hamathecium comprising 1-2 $\mu \mathrm{m}$ wide, septate, unbranched, cellular pseudoparaphyses, embedded in a gelatinous matrix. Asci $82-95 \times 9-14 \mu \mathrm{m}$ $(\bar{x}=88 \times 12 \mu \mathrm{m}, \mathrm{n}=20), 8$-spored, bitunicate, fissitunicate, cylindrical, pedicellate, rounded at the apex, with an ocular chamber. Ascospores 18-24×3-6 $\mu \mathrm{m}(\bar{x}=21 \times 4 \mu \mathrm{m}, \mathrm{n}=20)$, uni- to bi-seriate, partially overlapping, hyaline, fusiform, 1-septate, constricted at the septum, filled with a different sized guttule in each cell, surrounded by a mucilaginous sheath. Asexual morph: Not observed.

Culture characteristics - Colonies on PDA attaining $45 \mathrm{~mm}$ diam. Mycelium well developed, superficial. Chlamydospores not observed. At $25^{\circ} \mathrm{C}$, after 5 weeks, flat, greyish brown, with reverse dark greyish, with crenate edge.

Material examined - ITALY, Province of Forlì-Cesena, Teodorano - Meldola, on dead and aerial branch of Vitis vinifera, 15 February 2015, Erio Camporesi IT 2378 (MFLU 15-1083); culture, MFLUCC 17-1217; ITALY, Province of Forlì-Cesena, Teodorano - Meldola, on dead and aerial branch of Vitis vinifera, 21 February 2015, Erio Camporesi IT 2383 (MFLU 15-3508); culture, MFLUCC 17-1069.

Notes - This species is morphologically similar to A. populi and in the phylogenetic analysis of combined ITS, LSU, SSU and TEF1 sequence data, the isolates cluster with A. populi (Fig. 20). This study provides the first report of A. populi from Vitis species.

Didymellaceae Gruyter, Aveskamp \& Verkley, Mycol. Res. 113(4): 516 (2009)

This family was introduced to accommodate Didymella and phoma-like genera (Tibpromma et al. 2017). Didymellaceae consists of pathogens, endophytes and saprotrophs of many hosts (Chen et al. 2015). Chen et al. (2015) revised the family based on multi-gene (ITS, LSU, RPB2 and tub2) phylogenetic analysis and morphological observations.

Didymella Sacc., Michelia 2(no. 6): 57 (1880)

Didymella is a poorly understood genus and appears to be polyphyletic. Chen et al. (2015) amended this genus to accommodate Peyronellaea and several other associated phoma-like species. Most species in this genus produced chlamydospores in culture. A phylogenetic tree showing the placement of our strains is given (Fig. 22).

Didymella negeriana (Thüm.) Q. Chen \& L. Cai, in Chen, Jiang, Zhang, Cai \& Crous, Stud. Mycol. 82: 178 (2015)

Facesoffungi number: FoF 03830

Opportunistic pathogen on stems of Vitis vinifera. Sexual morph: Not observed. Asexual morph: Conidiomata on PDA 75-200 $\mu \mathrm{m}(\bar{x}=120 \mu \mathrm{m}, \mathrm{n}=10)$ diam., pycnidial, solitary or confluent, scattered, globose or irregular, glabrous, initially citrine-honey to sienna-olivaceous, but later turn black. Pycnidial wall thin-layered, pigmented. Conidial exudate saffron to pale vinaceous. Conidiogenous cells 6-10 $\times 3-7 \mu \mathrm{m}(\bar{x}=8 \times 5 \mu \mathrm{m}, \mathrm{n}=20)$, hyaline, smooth-walled, globose to bottleshaped. Conidia $5-7 \times 3-5 \mu \mathrm{m}(\bar{x}=6 \times 3 \mu \mathrm{m}, \mathrm{n}=30)$, ellipsoid to oblong, straight or slightly curved, initially hyaline, smooth-walled, acutely rounded at both ends, with several guttules.

Culture characteristics - Colonies on PDA, regular, floccose to woolly, circular, smoke grey aerial mycelium on the surface, reverse olivaceous grey, slow growing, reach $5 \mathrm{~cm}$ diam. after 7 days at $20{ }^{\circ} \mathrm{C}$. 

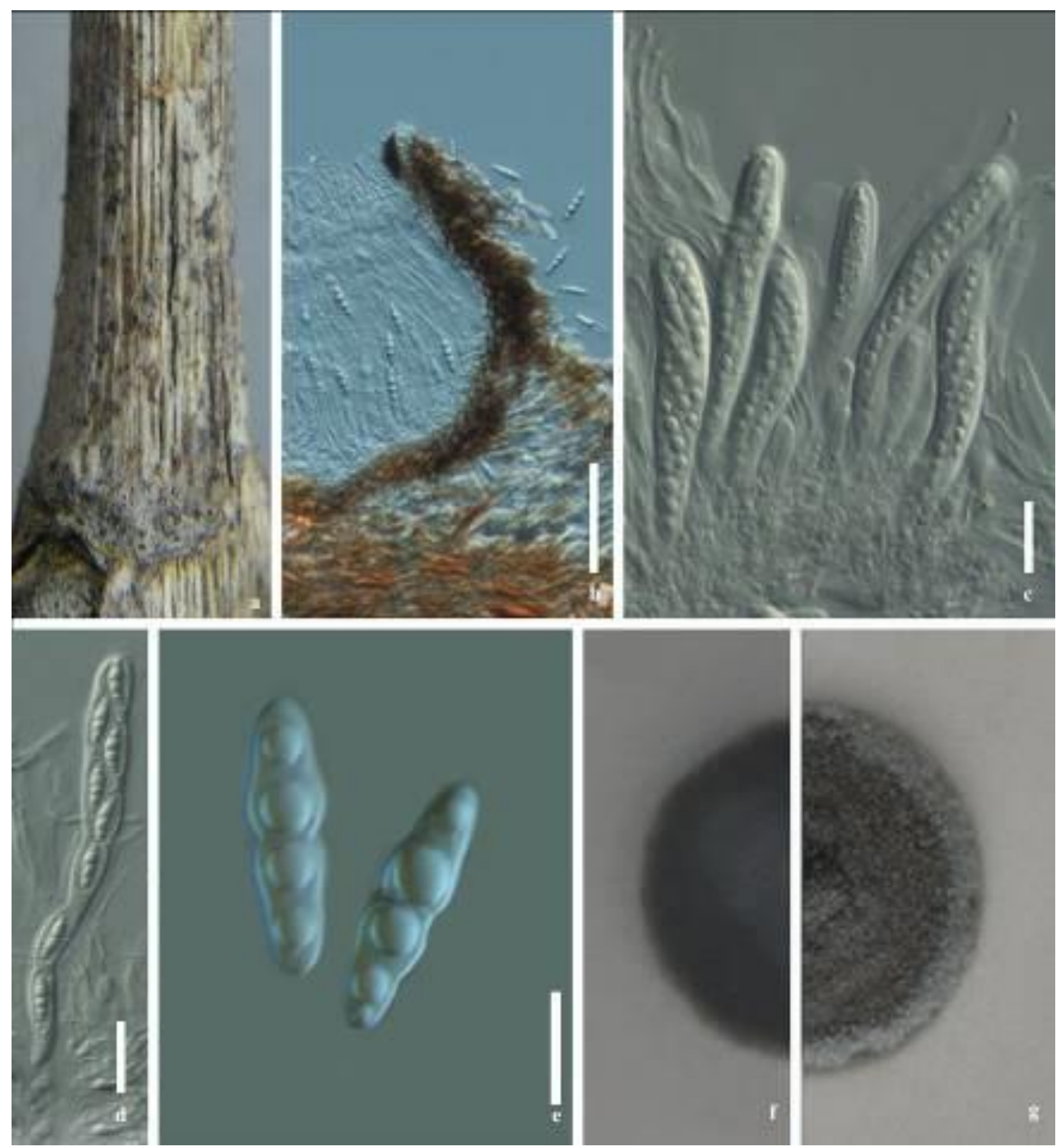

Fig. 21 - Angustimassarina populi. a. Appearance of immersed ascomata on host surface. b. Section through ascoma. c. Immature asci. d. Mature bitunicate ascus. e. Ascospores. f, g. Culture on PDA. Scale bars: $b=100 \mu \mathrm{m}, \mathrm{c}-\mathrm{d}=20 \mu \mathrm{m}, \mathrm{e}=10 \mu \mathrm{m}$.

Material examined - ITALY, Province of Forlì-Cesena, Teodorano - Meldola, on dead and aerial branch of Vitis vinifera, 16 February 2016, Erio Camporesi (MFLU 15-1086), ex-type living culture, MFLUCC 16-1394.

Notes - According to our phylogenetic analyses of combined LSU, ITS, RPB2 and $\beta$ tubulin sequence data of Didymella species (Fig. 22), our isolates cluster together in a well-defined clade with Didymella negriana (CBS 358.71) with relatively high bootstrap and Bayesian probabilities (100\% MP/1.00 PP). This species has been reported as a common opportunistic pathogen associated with disease symptoms on leaves, fruits, and stems of Vitis vinifera in southern Europe. The pathogen is often misidentified as Phoma viticola (currently known as Diaporthe ampelina), another pathogen of grapevine (de Gruyter et al. 1998). 


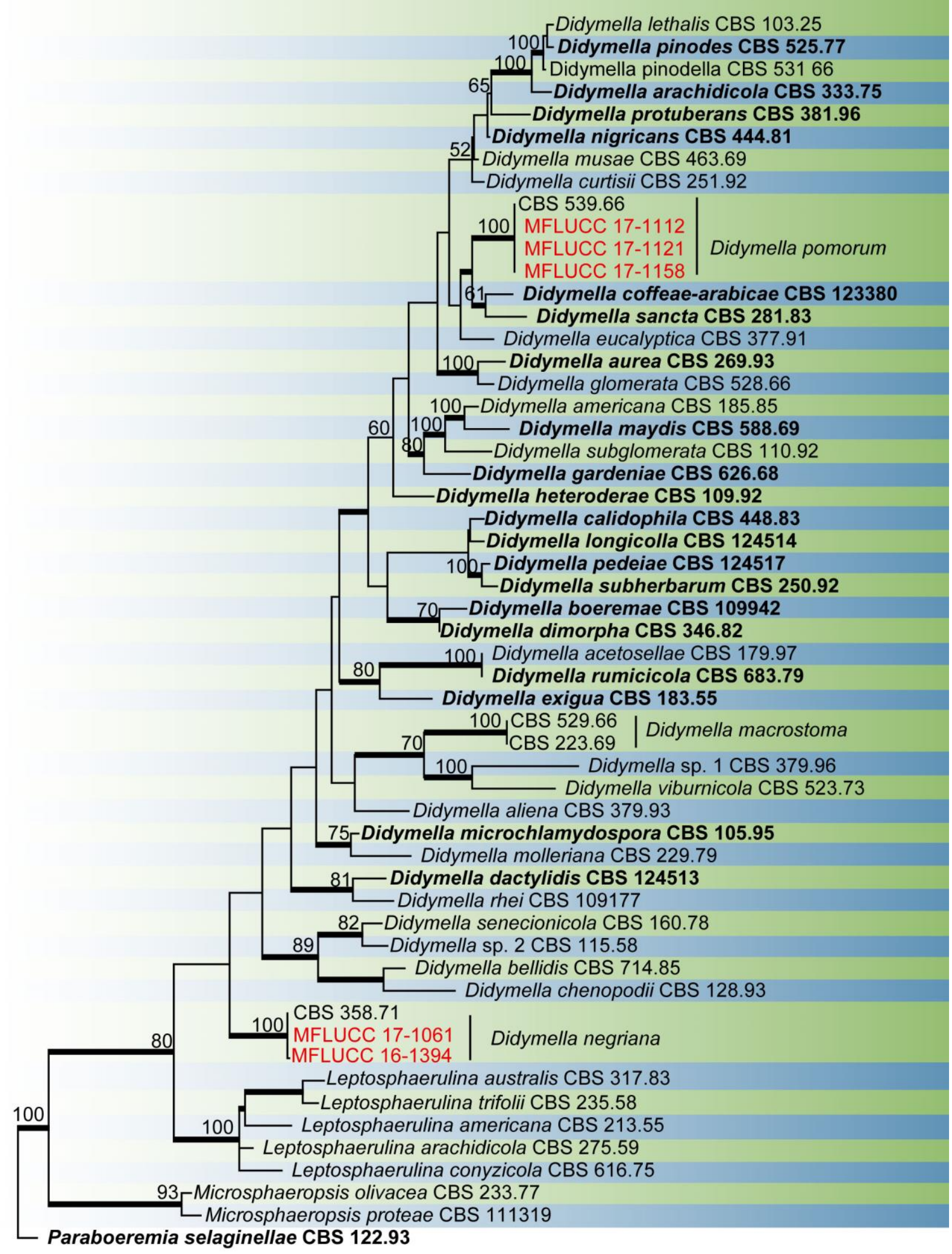

10

Fig. $\overline{22}$ - One of the equally most parsimonious trees obtained from combined analyses set of LSU, ITS, RPB2 and $\beta$-tubulin sequence data for Didymella species. MP values (>70\%) resulting from 1000 bootstrap replicates and Bayesian posterior probabilities above 0.95 are given at the nodes. The tree is rooted to Paraboeremia selaginellae (CBS 122.93). Ex-type strains are in bold and species from the current study are in red. 


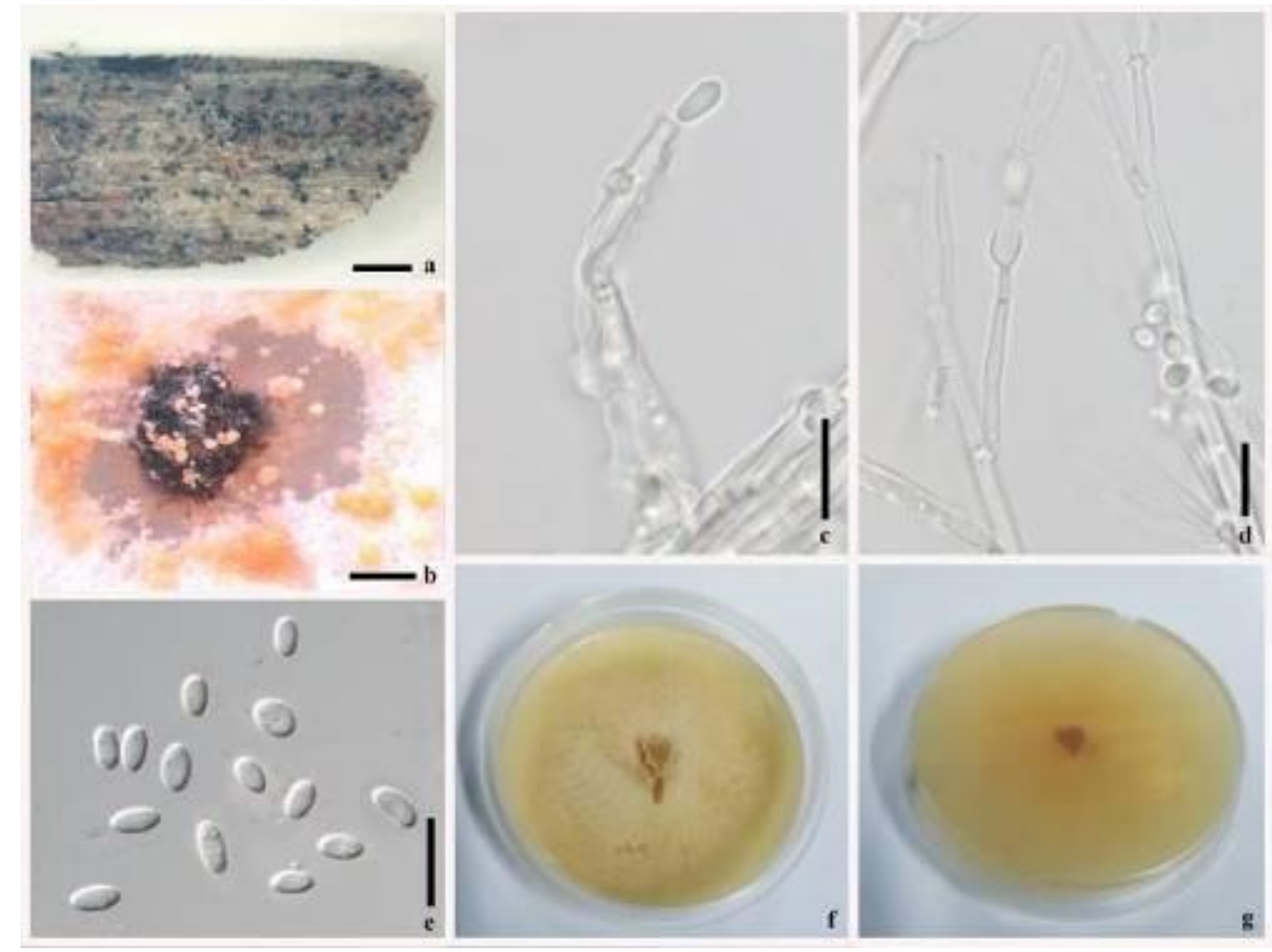

Fig. 23 - Didymella negeriana. a. Host tissue from which the species was isolated $b$. Saffron to pale vinaceous conidial mass on PDA c. Conidiogenesis d. Hyphae e. Conidia f-g. Upper view (f). and reverse view $(\mathrm{g})$. of colony on PDA. Scale bars: $\mathrm{a}=1 \mathrm{~mm}, \mathrm{~b}=2 \mathrm{~mm}, \mathrm{c}-\mathrm{e}=10 \mu \mathrm{m}$.

Didymella pomorum (Thüm.) Q. Chen \& L. Cai, Stud. Mycol. 82: 179 (2015)

Facesoffungi number: FoF 03829

Saprotrophic on dead root, shoot and leaves of Vitis vinifera. Sexual morph: Not observed. Asexual morph: Pycnidia mostly 100-200 $\mu \mathrm{m}$ diam., usually subglobose-ampulliform with a distinct ostiole, and often furrowed surface, solitary, but frequently confluent in groups up to 1000 $\mu \mathrm{m}$ diam. Conidial exudate usually whitish to cream, often later darkening to olivaceous brown. Fertile micropycnidia frequently occur. Conidia $4-8 \times 2-3 \mu \mathrm{m}(\bar{x}=6 \times 2 \mu \mathrm{m}, \mathrm{n}=40)$, variable in shape and dimensions, mostly ovoid-ellipsoidal, frequently with one large guttule and several smaller ones, hyaline, but with age becoming light brown. Chlamydospores solitary or in long chains or as dictyochlamydospores.

Culture characteristics - Colonies on PDA, regular, floccose to woolly, circular, smoke grey aerial mycelium on the surface, pale to olivaceous at centre, white at edge, with reverse brownish to blackish beneath dense mycelium, reaching $5 \mathrm{~cm}$ diam. after 7 days at $25^{\circ} \mathrm{C}$.

Material examined - CHINA, Beijing, on dead root of Vitis vinifera cv. Red Globe, 3 June 2015, Ruvishika Jayawardena, culture MFLUCC 17-1112; CHINA, Beijing, on dead shoot of $V$. vinifera cv. Red Globe, 3 June 2015, Ruvishika Jayawardena, culture MFLUCC 17-1121; CHINA, Beijing, on dead leaves of $V$. vinifera cv. Red Globe, 3 June 2015, Ruvishika Jayawardena, culture MFLUCC 17-1158. 
Notes - Didymella pomorum has been recorded as a saprotroph from Dendrobium fimbriata, Gentiana stramineae, Heracleum dissectum, Polygomun tataricum and Triticum sp. (Chen et al. 2017). This study provides the first report of this species associated with Vitis species.
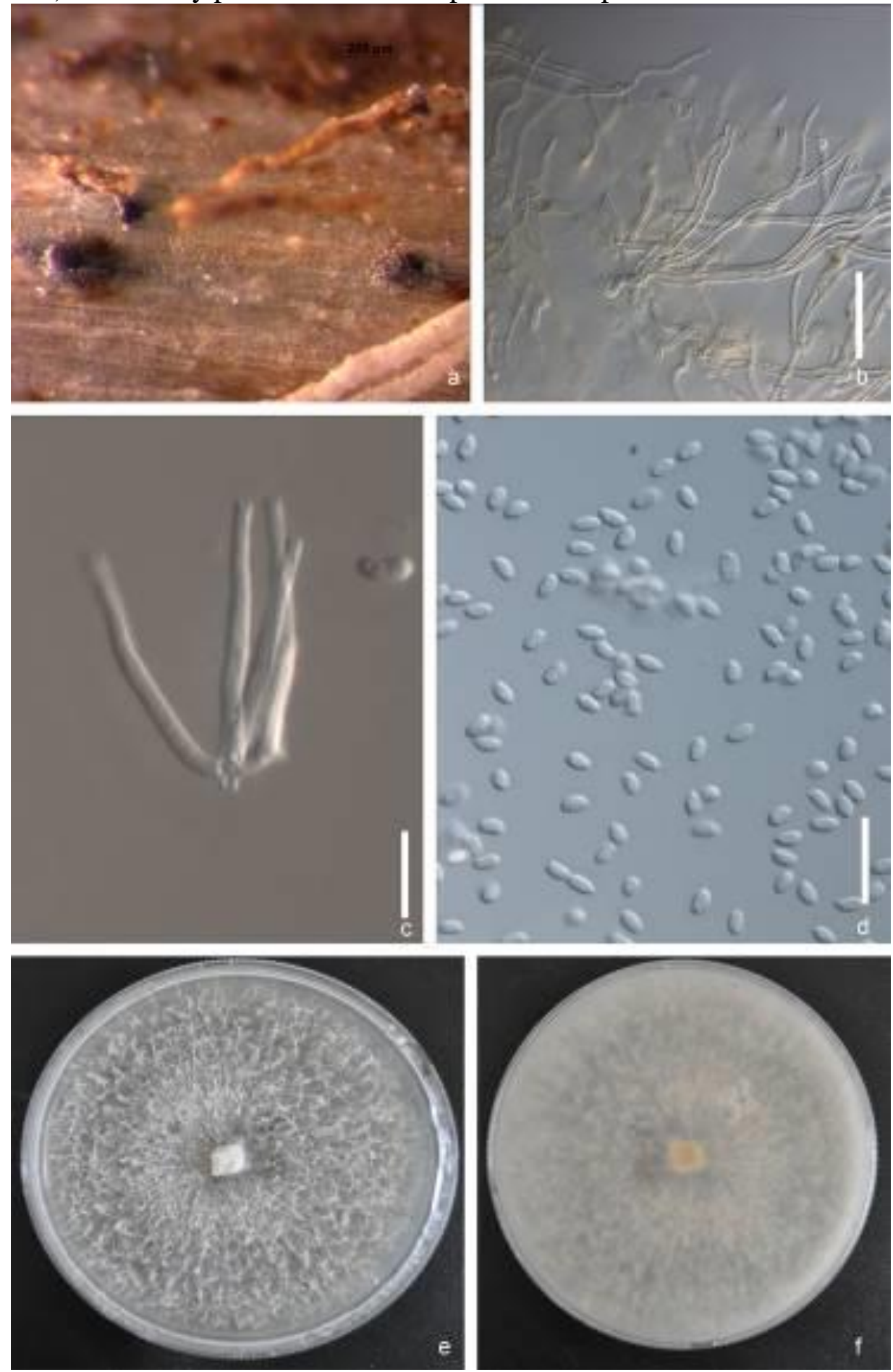

Fig. 24 - Didymella pomorum. a. Host tissue from which the species was isolated b. Hyphae c. Conidiophores d. Conidia e. Upper view of colony on PDA after 7 days f. Reverse view of colony on PDA after 7 days. Scale bars: $b-d=10 \mu \mathrm{m}$.

Epicoccum Link, Mag. Gesell. naturf. Freunde, Berlin 7: 32 (1816) [1815]

This genus belongs in the Didymellaceae (Aveskamp et al. 2010) and is characterized by epicoccoid and sub-cylindrical conidia (Chen et al. 2015). According to the combined gene phylogenetic analysis of LSU, ITS, RPB2 and $\beta$-tubulin sequence data, our strains clustered with $E$. nigrum, a common saprotroph associated with Vitis species (Fig. 25). 


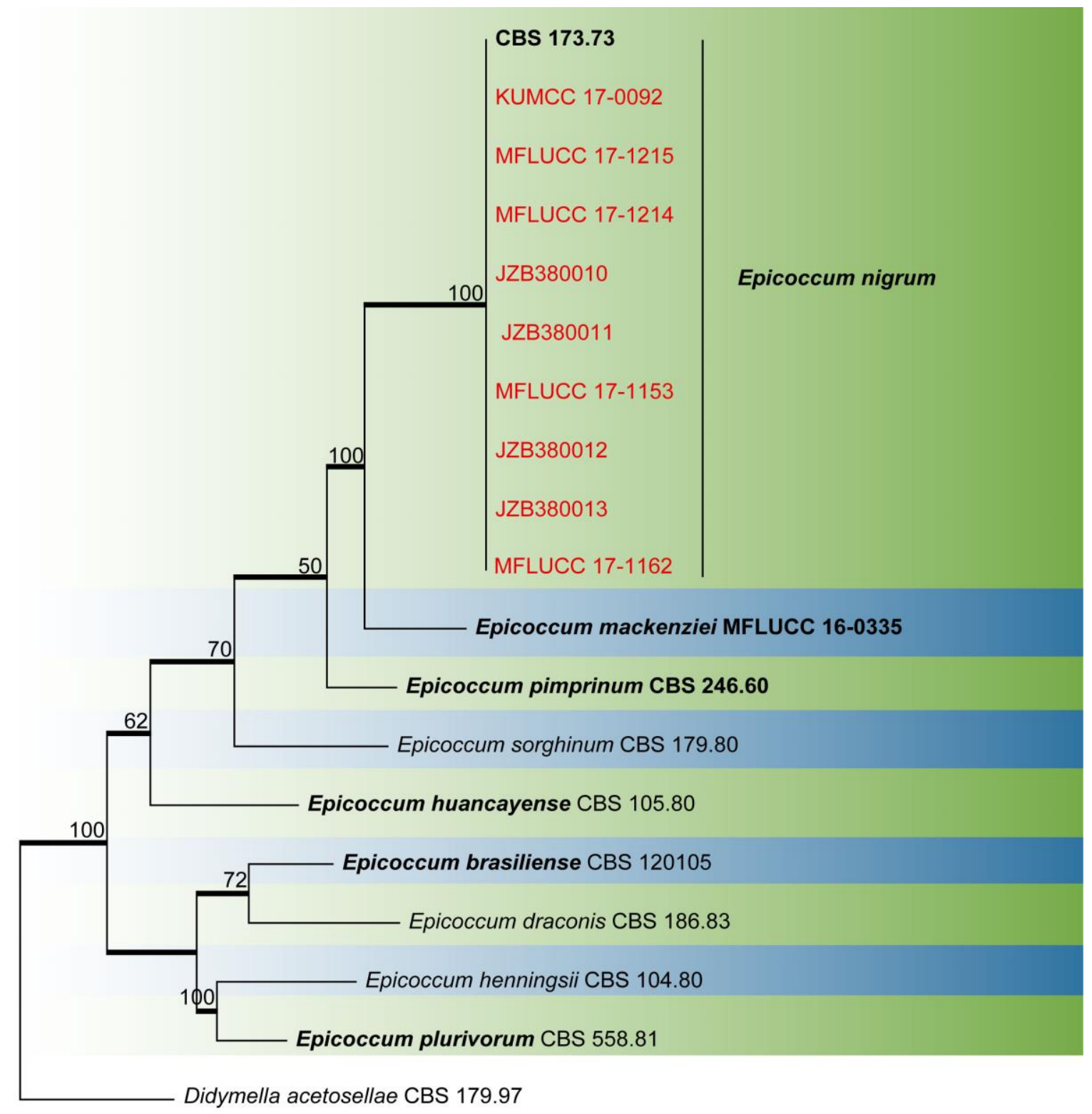

Fig. 25 - $\frac{10}{-}$ One of the eight most parsimonious trees obtained from a heuristic search of combined LSU, ITS, RPB2 and $\beta$-tubulin sequence data of taxa of Epicoccum. Parsimony bootstrap support values $\geq 50 \%$ are indicated at the nodes and branches with Bayesian posterior probabilities $\geq 0.90$ given in bold. Ex-type strains are in bold. Strains obtained in this study are in red. The tree is rooted with Didymella acetosellae CBS 179.97.

Epicoccum nigrum Link, Mag. Gesell. naturf. Freunde, Berlin 7: 32 (1816) [1815]

Facesoffungi number: FoF02685

Saprotrophic on dead and aerial branches of Vitis vinifera. Sexual morph: Not observed. Asexual morph: Conidiomata $250-700 \mu \mathrm{m}(\bar{x}=500 \mu \mathrm{m}, \mathrm{n}=10)$, pycnidial, mainly solitary, globose to irregularly shaped. Pycnidial wall pseudoparenchymatous, composed of 5-9 layers, outer wall olivaceous brown. Conidiogenous cells $4-5 \times 3-4 \mu \mathrm{m}(\bar{x}=2 \times 3 \mu \mathrm{m}, \mathrm{n}=20)$, phialidic, hyaline, smooth, globose to flask-shaped. Conidia 3-6×1-3 $\mu \mathrm{m}(\bar{x}=4 \times 2 \mu \mathrm{m}, \mathrm{n}=84)$, hyaline, unicellular, ovoid, ellipsoidal to oblong, or sub-cylindrical. Chlamydospores $7-21 \times 6-16 \mu \mathrm{m}(\bar{x}=12 \times 10 \mu \mathrm{m}$, $\mathrm{n}=20$ ), multicellular, globose or irregularly shaped, dictyosporous, solitary or in chains, smooth, verrucose, pale brown to dark brown. 
Culture characteristics - Colonies on PDA reaching $65-75 \mathrm{~mm}$ in 7 days at $25{ }^{\circ} \mathrm{C}$ entire margin, immersed mycelium completely covered by a mycelial mat which is densely floccose, bright yellow, reverse with orange center, becoming yellow towards the margin.

Material examined - ITALY, Province of Forlì-Cesena, near Pieve di Rivoschio, on dead and aerial branch of Vitis vinifera, 2 February 2015, Erio Camporesi IT 2363-3a, IT 2363-3b, (MFLU 15-1082); culture, MFLUCC 17-1214 and 17-1215; ITALY, Province of Forlì-Cesena, Fiumana - Predappio, on dead and aerial branch of $V$. vinifera, 13 February 2016, Erio Camporesi IT 2831-L, (MFLU 16-0879); culture, KUMCC 17-0092; CHINA, Beijing, on dead leaves of $V$. vinifera cv. Red Globe, 3 June 2015, Ruvishika S. Jayawardena, culture JZB380010; CHINA, Beijing, on dead leaves of $V$. vinifera cv. Red Globe, 3 June 2015, Ruvishika S. Jayawardena, culture JZB380011; CHINA, Beijing, on dead shoots of V. vinifera cv. Red Globe, 3 June 2015, Ruvishika S. Jayawardena, culture JZB380012; CHINA, Beijing, on dead shoots of $V$. vinifera cv. Red Globe, 3 June 2015, Ruvishika S. Jayawardena, culture JZB380013.

Notes - Epicoccum nigrum is a common saprotroph that can be found on many hosts (Aveskamp et al. 2010). This species has been recorded to be associated with Vitis sp. as an endophyte as well as a saprotroph in Spain and Switzerland (Gonzales \& Tello 2011, Garcia Benavides et al. 2013, Casieri et al. 2009). There are no records of E. nigrum associated with Vitis sp. in China or Italy in the SMML database.

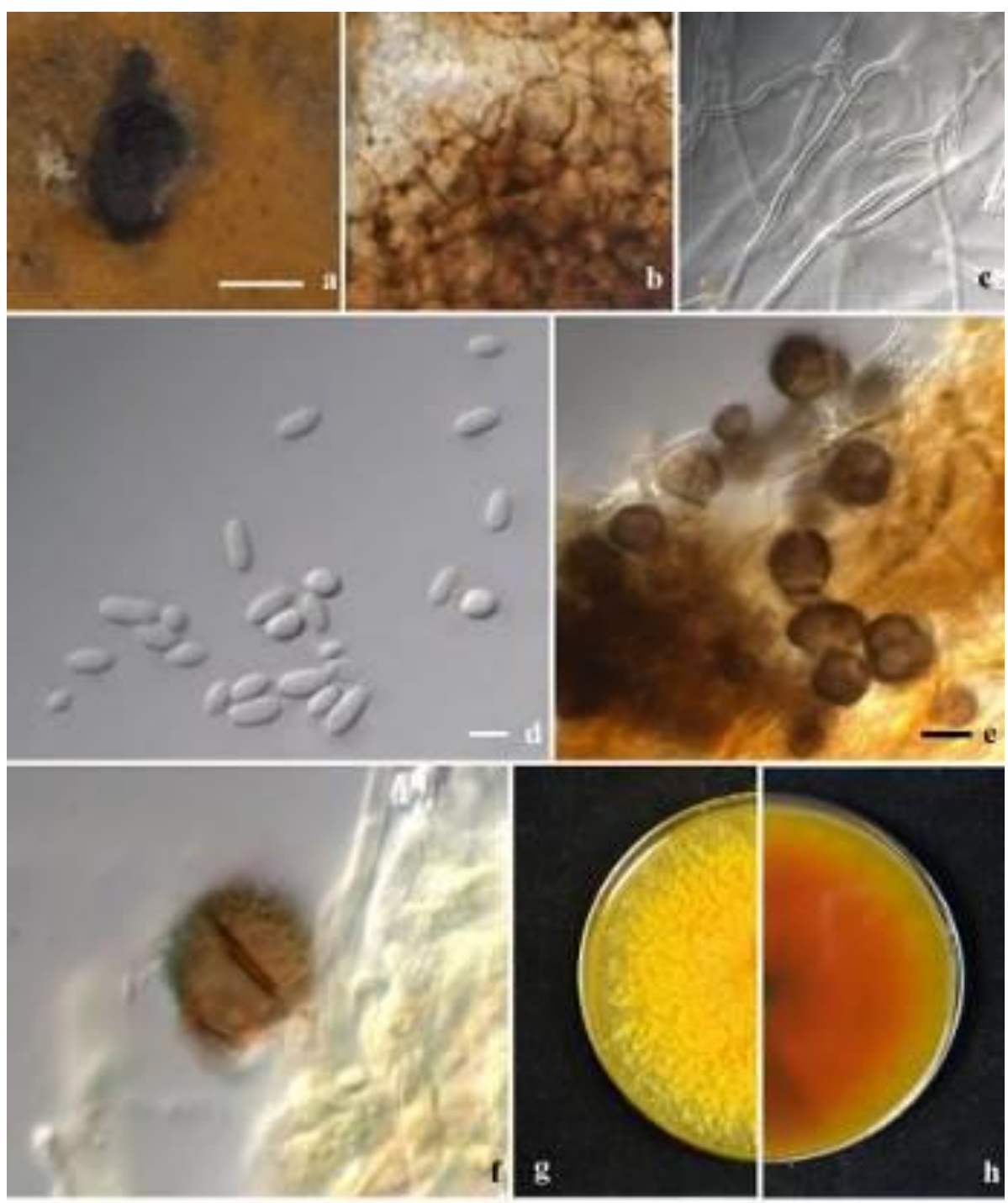

Fig. 26 - Epicoccum nigrum. a. Pycnidium. b. Section of pycnidial wall. c. Septate, branching hyaline to olivaceous-grey hyphae. d. Conidia. e-f. Chlamydospores. g. Upper view of 7 day old culture. h. Reverse view of 7 day old culture. Scale bars: $a=50 \mu \mathrm{m}, \mathrm{e}=20 \mu \mathrm{m}, \mathrm{d}=10 \mu \mathrm{m}$ scale bar of $\mathrm{d}$ applies to $\mathrm{f}$, and scale bar of e applies to $\mathrm{b}-\mathrm{c}$. 
Didymosphaeriaceae Munk, Dansk bot. Ark. 15(no. 2): 128 (1953)

Didymosphaeriaceae was introduced to accommodate species with 1-septate ascospores and trabeculate pseudoparaphyses (Liew et al. 2001, Ariyawansa et al. 2014, Tibpromma et al. 2017). Ariyawansa et al. (2014) synonymized Montagnulaceae under Didymosphaeriaceae. This family consists of saprotrophs, endophytes and pathogens.

Pseudocamarosporium Wijayaw. \& K.D. Hyde, in Wijayawardene, Hyde, Bhat, Camporesi, Schumacher, Chethana, Wikee, Bahkali \& Wang, Cryptog. Mycol. 35(2): 185 (2014)

Pseudocamarosporium was established by Wijayawardene et al. (2014b) for some camarosporium-like species grouping in Didymosphaeriaceae. This genus shows similar conidial morphology with Camarosporium sensu stricto, but differs in having paraphyses and microconidia (Wijayawardene et al. 2014b). We collected $P$. propinquum associated with dead branches of Vitis vinifera in Italy and it matched the epitype description (Wijayawardene et al. 2014b) and clustered together with the ex-type strain (Fig. 27).

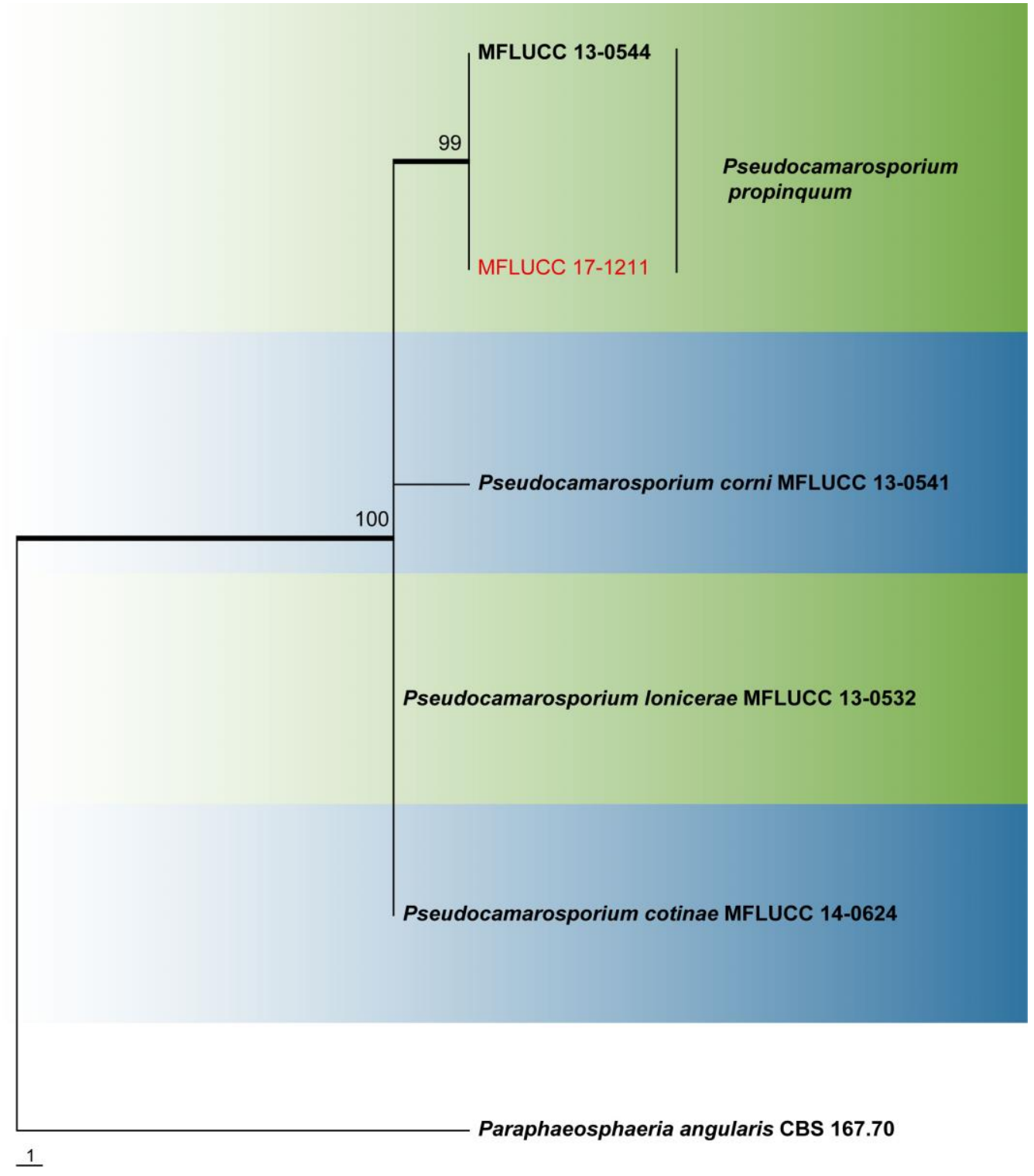

Fig. 27 - One of the ten most parsimonious trees obtained from a heuristic search of combined LSU, SSU and ITS sequence data of taxa of Pseudocamarosporium. Parsimony bootstrap support values $\geq 50 \%$ are indicated at the nodes and branches with Bayesian posterior probabilities $\geq 0.90$ are given in bold. Ex-type strains are in bold. Strains obtained in this study are in red. The tree is rooted with Paraphaeosphaeria angularis CBS 167.70. 
Pseudocamarosporium propinquum (Sacc.) Wijayaw., Camporesi \& K.D. Hyde, in Wijayawardene, Hyde, Bhat, Camporesi, Schumacher, Chethana, Wikee, Bahkali \& Wang, Cryptog. Mycol. 35(2): 191 (2014)

Facesoffungi number: FoF02162

Saprotrophic on dead and aerial branch of Vitis vinifera. Sexual morph: Not observed. Asexual morph: Conidiomata pycnidial $350-580 \mu \mathrm{m}$ diam, $100-180 \mu \mathrm{m}$ high $(\bar{x}=465 \times 168 \mu \mathrm{m}$, $\mathrm{n}=10$ ), solitary, scattered, black, immersed to sub-immersed, sub-globose or irregular in shape, ostiolate. Pycnidial wall 15-30 $\mu \mathrm{m}$, multi-layered, with inner most thin, hyaline layer, with 3-5 outer layers of brown-walled cells of textura angularis. Conidiophores reduced to conidiogenous cells. Conidiogenous cells 5-16×6-7 ( $\bar{x}=13 \times 6 \mu \mathrm{m}, \mathrm{n}=20)$, with percurrent phialidic development, smooth, short, hyaline, formed from the inner layer of the pycnidial wall. Conidia $10-14 \times 6-8 \mu m$ $(\bar{x}=12 \times 4 \mu \mathrm{m}, \mathrm{n}=40$ ), oblong to ellipsoidal, initially hyaline, aseptate, becoming muriform, with 3 transverse septa and 1-2 longitudinal septa, pale brown to dark brown, smooth-walled.
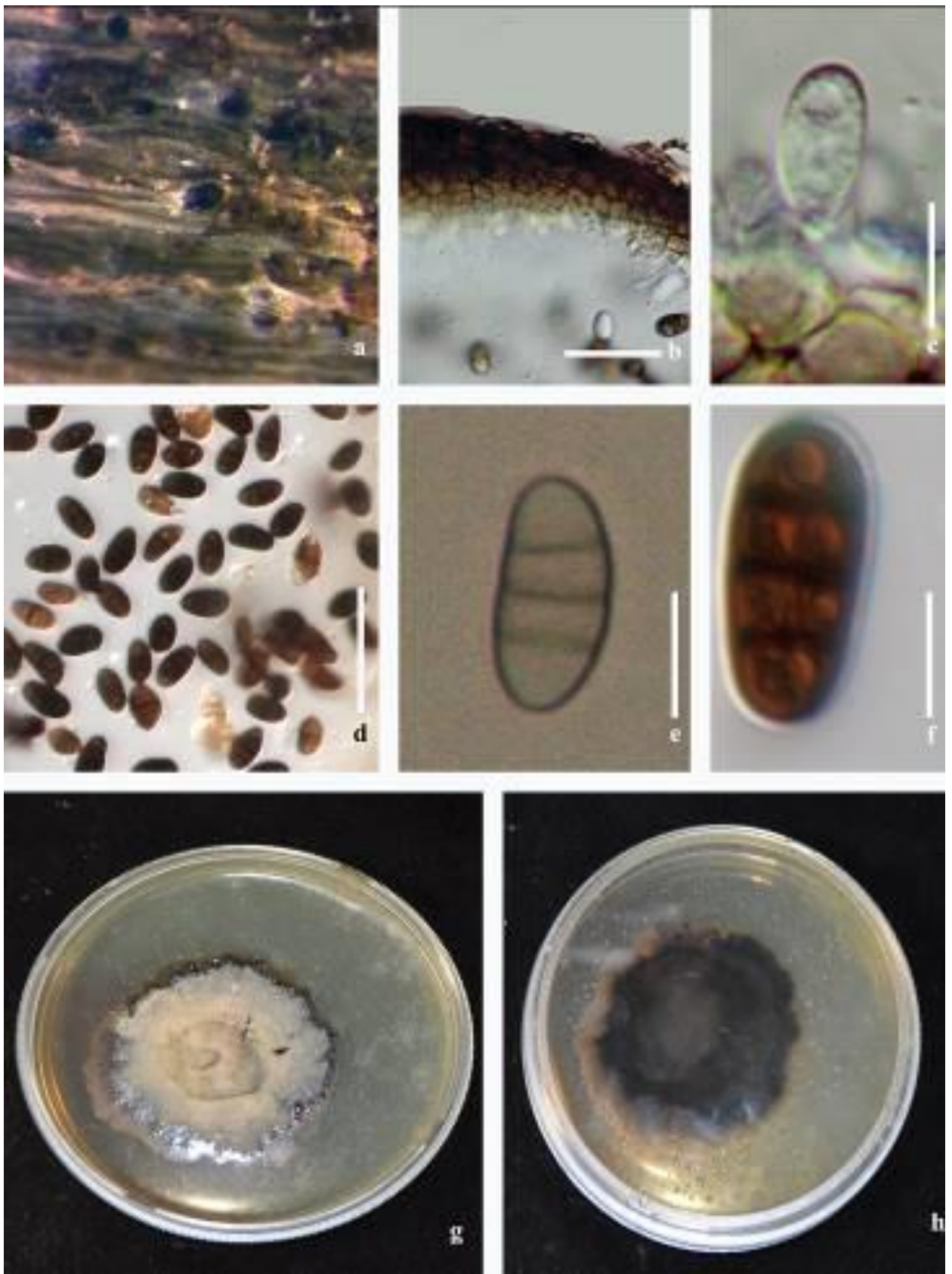

Fig. 28 - Pseudocamarosporium propinquum a Conidiomata on host tissue. b Cell wall of conidioma. c Conidiogenous cell. d-f Conidia. g Upper view of 14 day old culture. h Reverse view of 14 day old culture. Scale bars $\mathrm{b}=50 \mu \mathrm{m}, \mathrm{c}-\mathrm{f}=10 \mu \mathrm{m}$. 
Culture characteristics - Colonies on PDA at $25{ }^{\circ} \mathrm{C}$ reaching $50 \mathrm{~mm}$ after 14 days, circular, flat, moderately dense, surface greenish olivaceous, white at the margin, becoming dark olive, reverse black, entire to slightly undulate edge.

Material examined - ITALY, Forlì-Cesena Province, Tontola - Predappio, on dead and aerial branch of Vitis vinifera, 11 April 2016, E. Camporesi, IT 2931 (MFLU 16-1167); culture, KUMCC 17-0041, MFLUCC 17-1282. ITALY, Province of Forlì-Cesena, near Pieve di Rivoschio, on dead and aerial branch of $V$. vinifera, 2 February 2015, Erio Camporesi IT 2363 (MFLU 151082); living culture, MFLUCC 17-1211.

Notes - There are no previous records of the genus Pseudocamarosporium on Vitis sp. Therefore, we provide the first report of this species associated with Vitis vinifera in Italy as well as in the world.

Lophiostomataceae Sacc. [as 'Lophiostomaceae'], Syll. fung. (Abellini) 2: 672 (1883)

Based on the formation of a slit-like ostiolar opening on a laterally compressed papilla, Nitschke (1869) introduced Lophiostomataceae. This family was designated as a separate family in the Pleosporales by Saccardo (1883). The family has been treated by Thambugala et al. (2014) and several new species have been described in recent publications (e.g. Thambugala et al. 2014, Hyde et al. 2017, Tibpromma et al. 2017).

Lophiostoma Ces. \& De Not., Comm. Soc. crittog. Ital. 1(fasc. 4): 219 (1863)

Lophiostoma was established by Cesati \& De Notaris (1863) to accommodate $L$. macrostomum. There are 446 epithets under this genus in Index Fungorum (2018). Strains obtained in this study clustered with the other representative strains of $L$. macrostomum with high bootstrap support (Fig. 38).

Lophiostoma macrostomum (Tode) Ces. \& De Not., Symbolae Mycologicae: 7 (1870)

Facesoffungi number: FoF03831

Saprotrophic on dead and aerial branch of Vitis vinifera. Sexual morph: Ascomata 450-500 $\mu \mathrm{m}$ high, $510-550 \mu \mathrm{m}$ diam. $(\bar{x}=500 \times 540 \mu \mathrm{m}, \mathrm{n}=10)$, scattered to gregarious, semi-immersed to densely erumpent, carbonaceous, dark brown to black, globose to subglobose. Ostiole slit-like with a small to large flat crest-like apex composed of pseudoparenchymatous cells. Peridium 30-50 $\mu \mathrm{m}$ wide $(\bar{x}=37 \mu \mathrm{m}, \mathrm{n}=12)$, thick at the sides, broad at the apex and thinner at the base, inner layer composed of hyaline textura angular cells, outer layer dark brown to black. Hamathecium of septate, long, hyaline, anastomosing and branched, cellular pseudoparaphyses, embedded in gelatinous matrix between and above the asci. Asci $90-120 \times 10-13 \mu \mathrm{m}(\bar{x}=110 \times 12 \mu \mathrm{m}, \mathrm{n}=10), 8$ spored, bitunicate, fissitunicate, cylindrical to clavate, with furcate pedicel, rounded at the apex with a minute ocular chamber. Ascospores 28-35×4-6 $\mu \mathrm{m}(\bar{x}=32 \times 5 \mu \mathrm{m}, \mathrm{n}=20)$, uniseriate or partially biseriate, narrowly fusiform with acute ends, 1-3-septate and slightly constricted at septa, with a distinct oil drop in each cell, smooth-walled, hyaline. Asexual morph: Not observed.

Material examined - ITALY, Province of Forlì-Cesena, Trivella di Predappio, dead and aerial branch of Vitis vinifera, 30 December 2014, Erio Camporesi, IT 2323 (MFLU 15-1076); ITALY, Province of Forlì-Cesena, near Pieve di Rivoschio, dead and aerial branch of $V$. vinifera, 2 February 2015, Erio Camporesi, IT 2363 (MFLU 15-1082).

Notes - Species of this genus have been reported on Vitis species in different countries, but Lophiostoma macrostomum has been previously recorded only as an endophyte from Vitis sp. in Pakistan (Ahmad et al. 1997) and as a saprobe (Zhang et al. 2009). A culture is unavailable for the strain in this study and sequencing from fruiting bodies was conducted. This study provides the first report of L. macrostomum as a saprotroph as well as a new record from Italy associated with $V$. vinifera.

Massariaceae Nitschke, Verh. naturh. Ver. preuss. Rheinl. 26: 73 (1869)

Massariaceae was introduced by Nitschke (1869) to accommodate Massaria. 

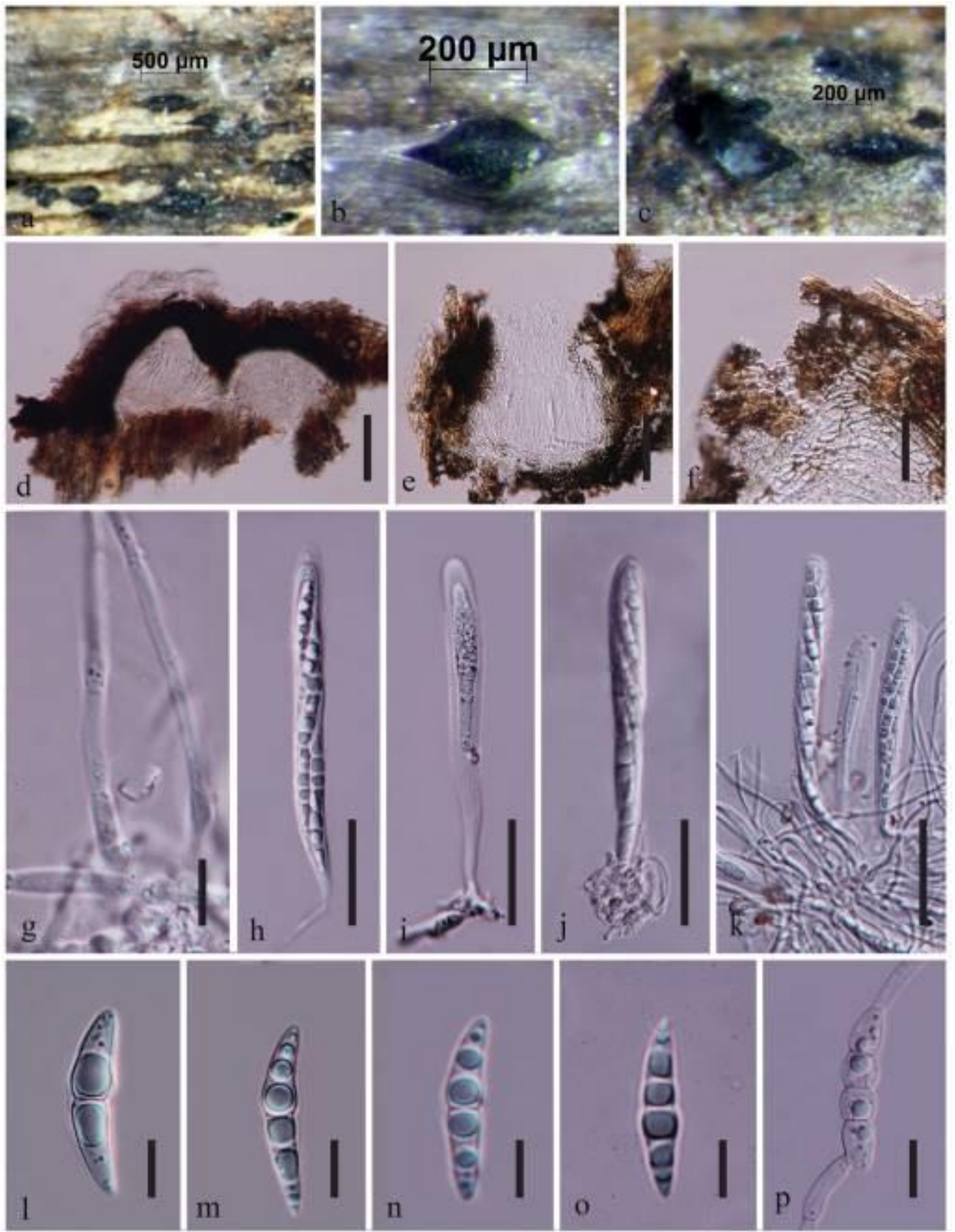

Fig. 29 - Lophiostoma macrostomum a, b Ascomata on host surface. c Section of ascoma. d, e Section through ascoma. f Peridium. g Pseudoparaphyses. h-k Asci. l-o Ascospores. p Germinated spore. Scale bars d, e=100 $\mu \mathrm{m}, \mathrm{f}, \mathrm{h}-\mathrm{k}=30 \mu \mathrm{m}, \mathrm{g}=5 \mu \mathrm{m}, 1-\mathrm{p}=10 \mu \mathrm{m}$.

Neomassaria Mapook, Camporesi \& K.D. Hyde, in Hyde et al., Fungal Diversity: 10.1007/s13225016-0373-x, [74] (2016)

This genus was introduced to accommodate $N$. fabacearum (Hyde et al. 2016) and has only one species epithet in Index Fungorum (2018). Our strain clustered with the type strain with high bootstrap support (Fig. 30). 


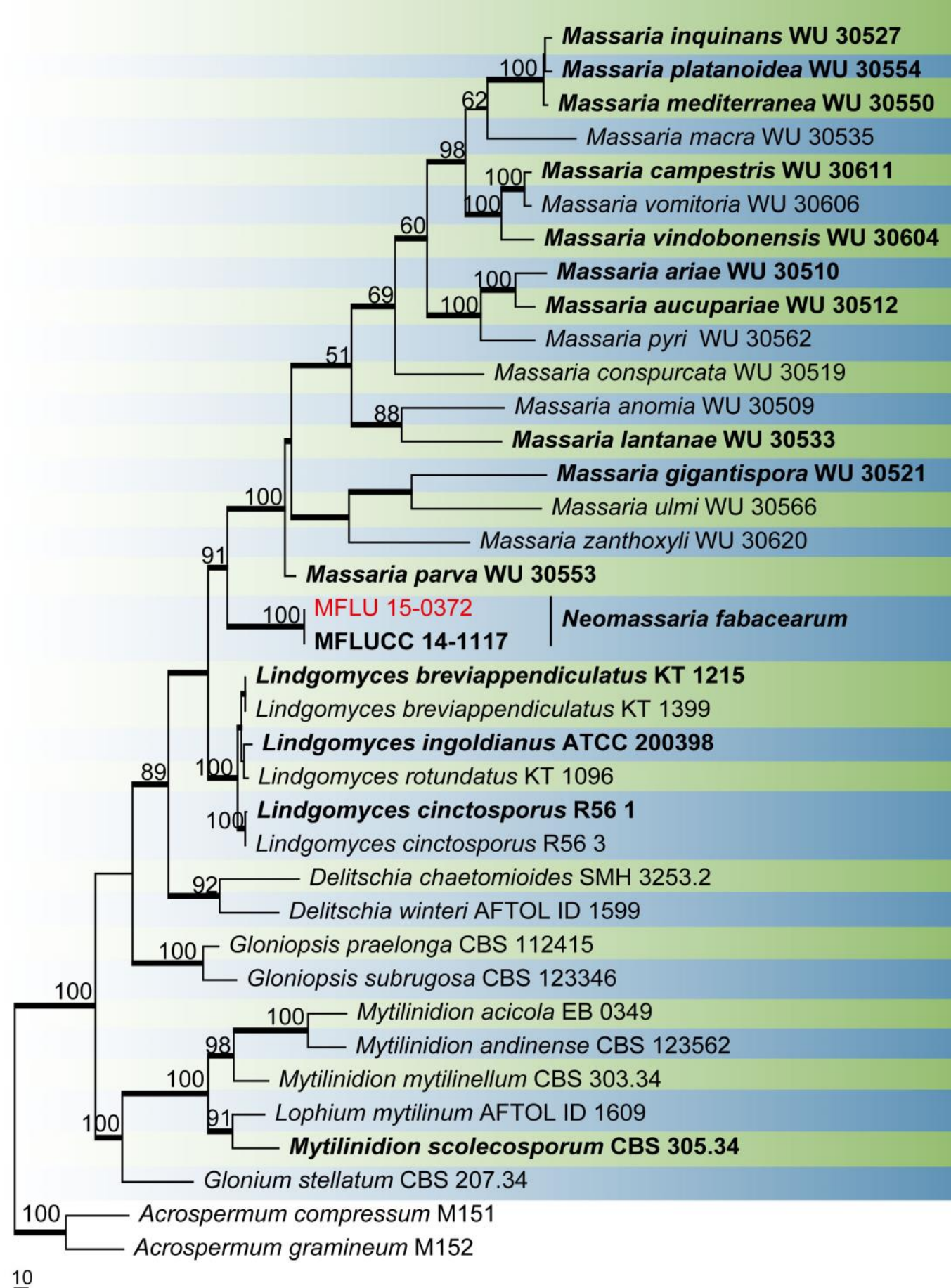

Fig. 30 - One of ten most parsimonious trees obtained from a heuristic search of combined LSU, SSU and TEF1 sequence data of Massariaceae. Parsimony bootstrap support values $\geq 75 \%$ are indicated at the nodes and branches with Bayesian posterior probabilities $\geq 0.90$ are given in bold. Ex-type strains are in bold. Strains isolated in this study are shown in red. The tree is rooted with Acrospermum compressum (M151) and A. gramineum (M152).

Neomassaria fabacearum Mapook, Camporesi \& K.D. Hyde, in Hyde et al., Fungal Diversity: 10.1007/s13225-016-0373-x, [77] (2016)

Facesoffungi number: FoF02438

Saprotrophic on dead and aerial branch of Vitis vinifera. Sexual morph: Ascomata 210 $250 \mu \mathrm{m}$ high, 215-245 $\mu \mathrm{m}$ diam. $(\bar{x}=227 \times 235 \mu \mathrm{m}, \mathrm{n}=5)$, immersed, solitary or scattered, coriaceous, globose to subglobose, brown to dark brown, Ostiole central. Peridium 10-25 $\mu \mathrm{m}$ wide, comprising light brown cells of textura angularis. Hamathecium comprising 1-1.5 $\mu \mathrm{m}$ wide, cylindrical to filiform, septate, branched pseudoparaphyses. Asci $65-105 \times 10-15 \mu \mathrm{m}(\bar{x}=86 \times 12 \mu \mathrm{m}$, 
$\mathrm{n}=10$ ), 8-spored, bitunicate, oblong to cylindrical, short pedicellate, with a wide ocular chamber. Ascospores 19-21 $\times 5-6 \mu \mathrm{m}(\bar{x}=20 \times 5 \mu \mathrm{m}, \mathrm{n}=10)$, overlapping 1-2-seriate, hyaline, ellipsoid to broadly fusiform, 1-septate, constricted at the septum, surrounded by hyaline gelatinous sheath observed clearly when mounted in Indian ink. Asexual morph: Not observed.

Material examined - ITALY, Province of Forlì-Cesena, Dovadola, on dead aerial branch of Vitis vinifera, 17 January 2014, Erio Camporesi, IT 1653 (MFLU 15-0372).

Notes - A culture is not available for this strain, and sequencing from the fruiting bodies were conducted. Neomassaria fabacearum is a saprotroph on Hippocrepis emerus (Hyde et al. 2016), and this study provides the first record of this species as a saprotroph on Vitis vinifera as well as a new record from Italy.

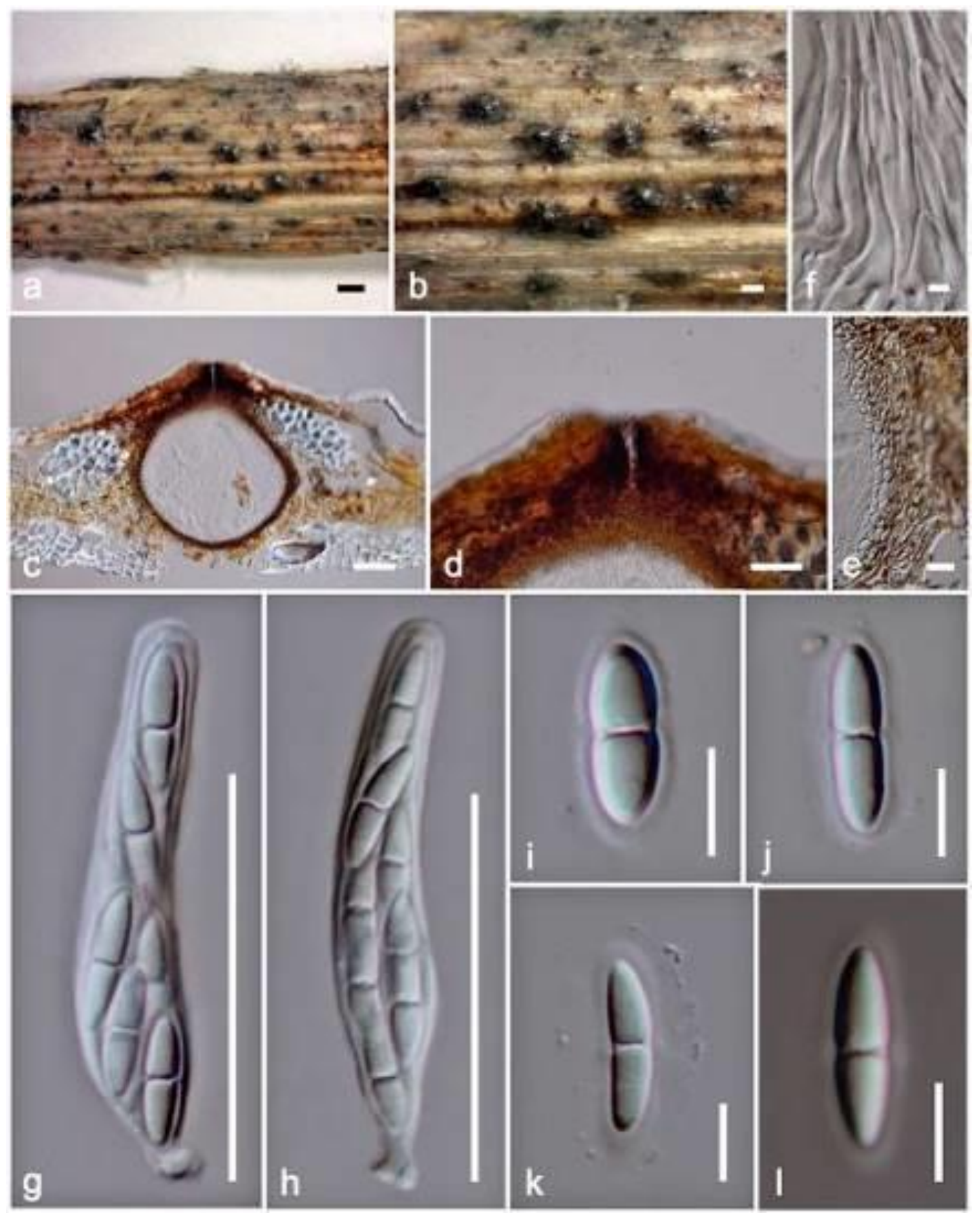

Fig. 31 - Neomassaria fabacearum. a, b. Appearance of ascomata on substrate. c. Section through ascoma. d. Ostiole. e. Peridium. f. Pseudoparaphyses. g, h. Asci. i-k. Ascospores. 1. Ascospore surrounded by hyaline gelatinous sheath in Indian ink. Scale bars: $a=500 \mu \mathrm{m}, b=200 \mu \mathrm{m}, \mathrm{c}=100$ $\mu \mathrm{m}, \mathrm{d}, \mathrm{g}-\mathrm{h}=50 \mu \mathrm{m}, \mathrm{e}=20 \mu \mathrm{m}, \mathrm{i}-\mathrm{l}=10 \mu \mathrm{m}, \mathrm{f}=5 \mu \mathrm{m}$. 
Pleosporaceae Nitschke, Verh. naturh. Ver. preuss. Rheinl. 26: 74 (1869)

Pleosporaceae is the largest family in Pleosporales and members of this family are pathogens or saprotrophs. Ariyawansa et al. (2015) revised the family and accepted 18 genera.

Alternaria Nees, Syst. Pilze (Würzburg): 72 (1816) [1816-17]

Alternaria was introduced by Nees (1816) and is a ubiquitous genus that includes saprobic, endophytic and pathogenic species associated with a wide variety of substrates (Woudenberg et al. 2013). Several species of this genus are known to be associated with grapevine. We provide accounts of A. alternata and A. vitis from Vitis sp. and a new species is introduced based on morphological traits and phylogeny (Fig. 32).

Alternaria alternata (Fr.) Keissl., Beih. bot. Zbl., Abt. 2 29: 434 (1912)

Facesoffungi number: FOF03825

Saprotrophic on dead stems and inflorescence of Vitis vinifera. Sexual morph: Not observed. Asexual morph: Conidiophores 40-50 $\times 3-6 \mu \mathrm{m}(\bar{x}=26 \times 5 \mu \mathrm{m}, \mathrm{n}=20)$ solitary to clustered, simple or branched, straight or flexuous, sometimes geniculate, pale, olivaceous or golden brown, smooth. Conidia $20-63 \times 9-18 \mu \mathrm{m}(\bar{x}=43 \times 12 \mu \mathrm{m}, \mathrm{n}=40)$, produced in single or branched chains on short conidiophores, obclavate, obpyriform, ovoid or ellipsoidal, pale to mid golden brown, 3-8 transverse and longitudinal septa, verruculose, tapering in the lower half into a narrow tail extension, upper part with a very short rounded beak ending abruptly. On PDA, conidia 22-38 $\times 6-11 \mu \mathrm{m}(\bar{x}=31 \times 7 \mu \mathrm{m}, \mathrm{n}=40)$, in long and sometimes branched chains of $8-12$ spores, obclavate, dark olive brown, 4-8 transverse and 0-2 longitudinal or oblique septa.

Culture characteristics - Colonies growing on PDA reaching $60 \mathrm{~mm}$ in 7 days at $25^{\circ} \mathrm{C}$, initially greyish with a very thin white margin and cottony texture, later becoming dark olive green to dark brown, mycelium superficial, effuse, radially striate, with irregular edge, brown to dark brown coloured hyphae.

Material examined - ITALY, Province of Forlì-Cesena, near Teodorano - Meldola, on dead aerial branch of Vitis vinifera, 15 February 2015, Erio Camporesi, IT 2380 (MFLU 15-0372), culture MFLUCC 17-1219 (KUMCC 17-0118); CHINA, Yunnan, on dead shoot of V. vinifera cv. Carbanate Gernischet, 11 June 2015, X. H. Li, culture MFLUCC 17-1187; CHINA, Beijing, on dead shoot of $V$. vinifera cv. Red Globe, 3 June 2015, Ruvishika Jayawardena, culture MFLUCC 17-1118, MFLUCC 17-1129, MFLUCC 17-1150, MFLUCC 17-1151; CHINA, Beijing, on dead inflorescence of $V$. vinifera cv. Red Globe, 3 June 2015, Ruvishika Jayawardena, culture MFLUCC 17-1122, MFLUCC 17-1130

Notes - Alternaria alternata is a well-known pathogen throughout the world causing various diseases on economically important crops. This species is known to cause a fruit rot of grapevine. Alternaria alternata has been also recorded as an endophyte and a saprotroph from grapevine worldwide (Jayawardena et al. 2018).

Alternaria italica J.F. LI, Camporesi \& K.D. Hyde sp. Nov.

Index Fungorum numbers: IF553987 Facesoffungi number: FoF 03880

Holotype: HKAS 100717

Saprotrophic on dead and aerial branch of Vitis vinifera. Sexual morph: Not observed. Asexual morph: Mycelium superficial on substrate, composed of septate, branched, smooth, thin-walled, brown to dark brown hyphae. Conidiophores 250-300 $\times 17-21 \mu \mathrm{m}(\bar{x}=278 \times 18 \mu \mathrm{m}, \mathrm{n}=100)$, macronematous, mononematous, light brown to brown, thick-walled, smooth, septate, branched at the base, straight or flexuous, cylindrical. Conidiogenous cells $8-13 \times 9-15 \mu \mathrm{m}(\bar{x}=10 \times 11 \mu \mathrm{m}$, $\mathrm{n}=100$ ), cicatrized, monoblastic, integrated, terminal, determinate or percurrent, cylindrical, doliiform, subhyaline, smooth, thin-walled. Conidia 76-98 $\times 23-39 \mu \mathrm{m}(\bar{x}=86 \times 32 \mu \mathrm{m}, \mathrm{n}=100)$, acrogenous, holoblastic, solitary, light grey to brownish grey, 8-11-septate or more, dry, simple, straight, curved, fusiform, obpyriform, obturbinate or subglobose, catenate, sometimes rostrate, smooth, thin-walled. 


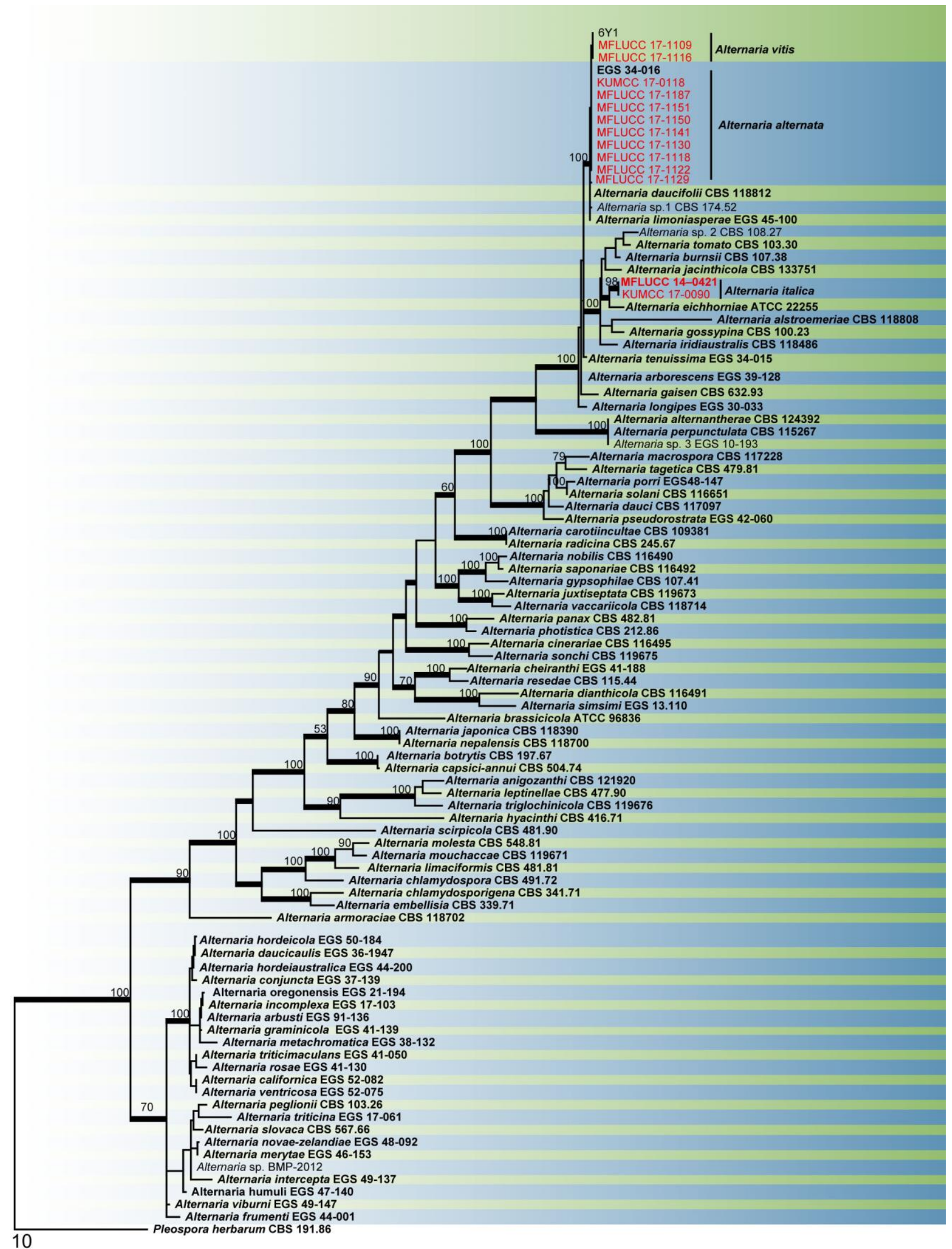

Fig. 32 - One of ten most parsimonious trees obtained from a heuristic search of combined ITS, LSU, GAPDH, RPB2 and TEF1 sequence data of taxa from Alternaria. Parsimony bootstrap support values $\geq 75 \%$ are indicated at the nodes and branches with Bayesian posterior probabilities $\geq 0.95$ given in bold. Ex-type strains are in bold. Strains of this study are in red. The tree is rooted with Pleospora herbarum CBS 191.86. 

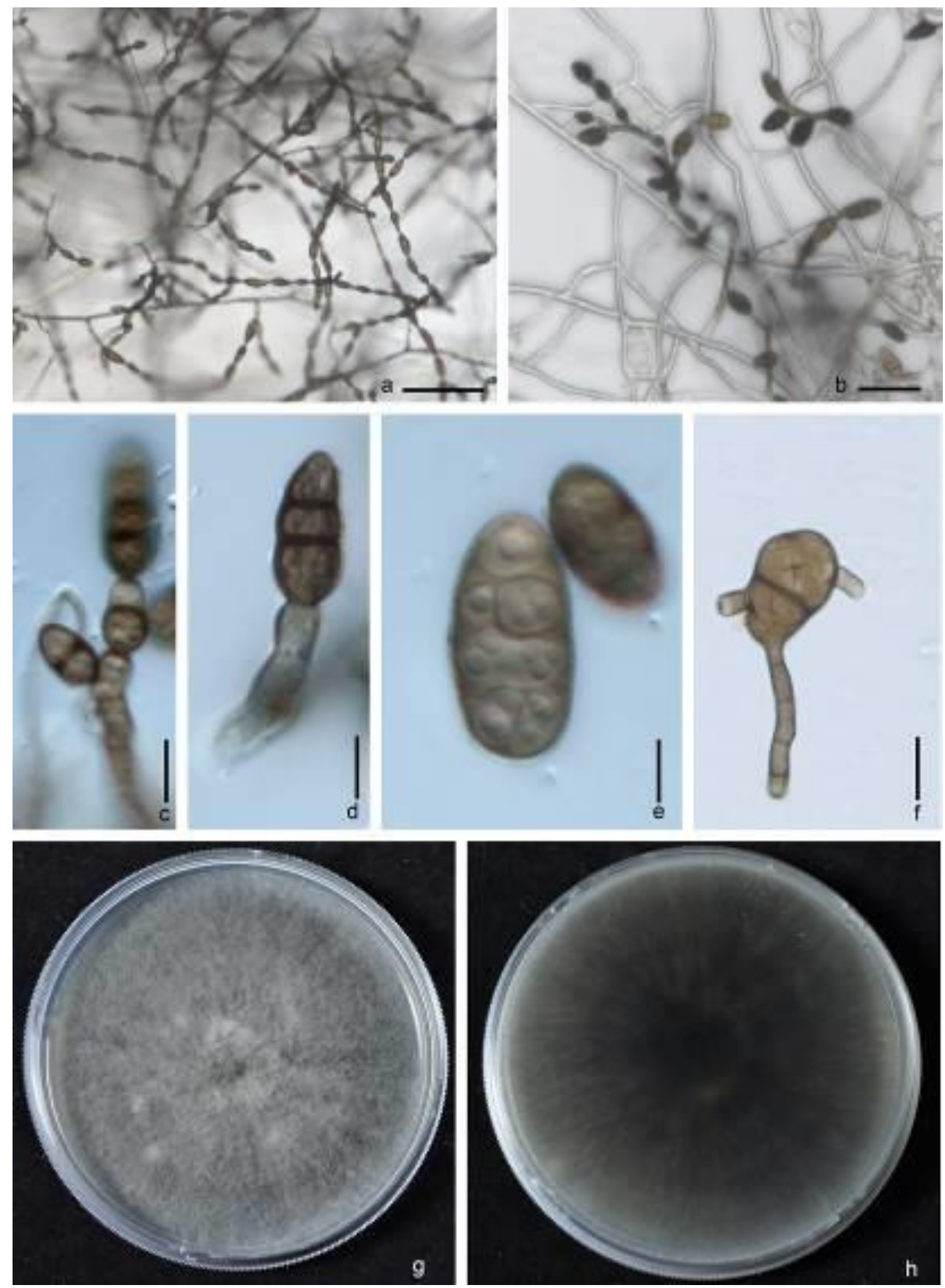

Fig. 33 - Alternaria alternata. a-b. Conidial chains. c-d. Conidiophores. e. Conidia. f. Germinated conidium g. Upper view of the culture on PDA. h. Reverse view of the culture on PDA. Scale bars: $\mathrm{a}-\mathrm{b}=100 \mu \mathrm{m}, \mathrm{c}-\mathrm{f}=20 \mu \mathrm{m}$.

Cultural characteristics - Conidia germinating on PDA within 14 hours and germ tubes produced from all cells. Colonies growing on PDA, hairy or cottony, brown to dark brown, reaching $5 \mathrm{~mm}$ in 20 days at $25^{\circ} \mathrm{C}$, mycelium superficial, effuse, radially striate, with irregular edge, brown to dark brown hyphae; asexual spores and sexual spores not formed within 60 days.

Material examined - ITALY, Province of Forlì-Cesena, Via Pietro Nenni - Forlì, on dead and aerial branch of Vitis vinifera, 12 November 2013, Erio Camporesi, IT 1513 (HKAS 100717 holotype), culture MFLUCC 14-0421= KUMCC 17-0123.

Notes - Based on morphology and multigene phylogentic support we introduce A. italica to accommodate the new taxon. 


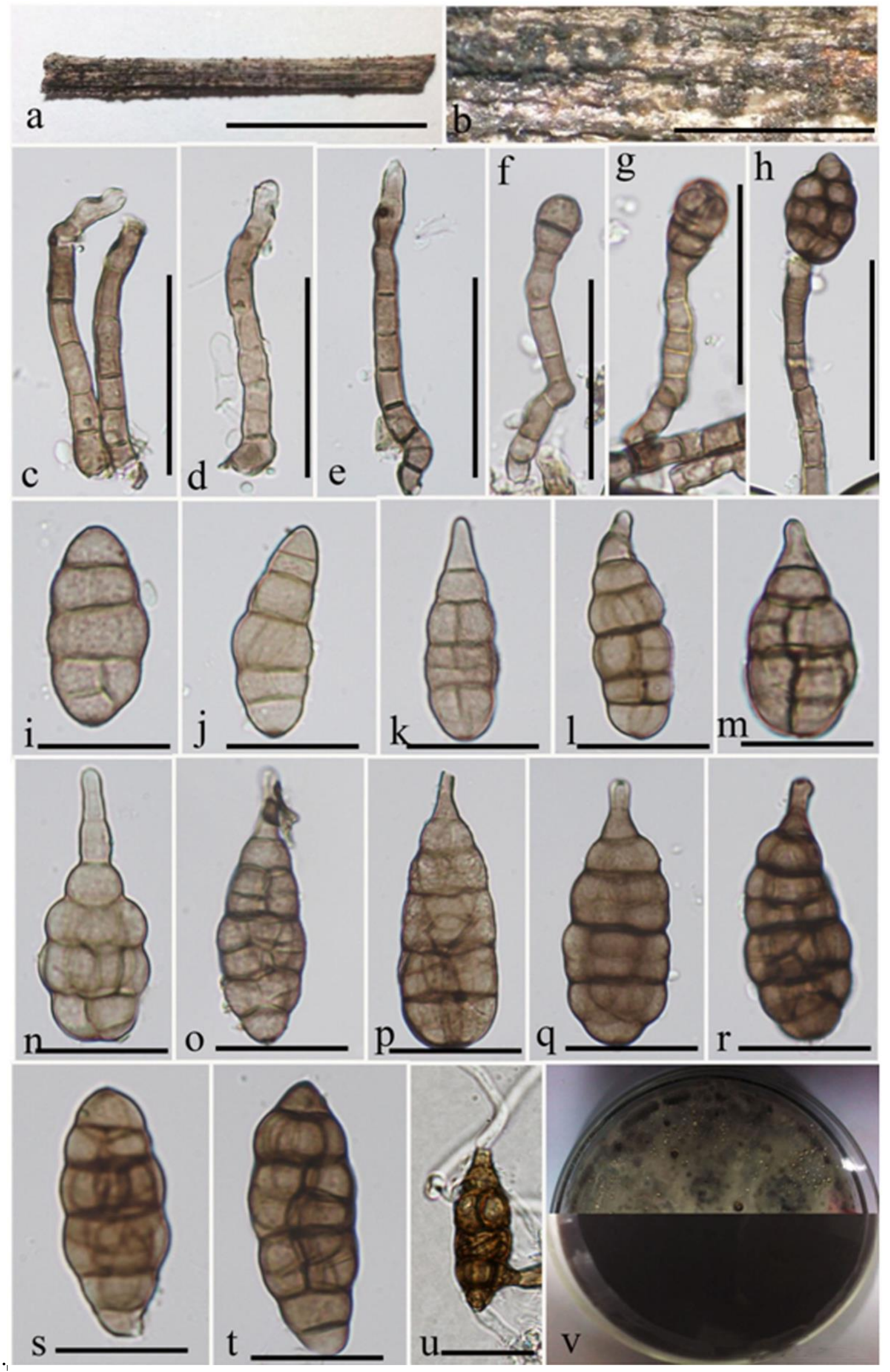

Fig. 34 - Alternaria italica. a. Host tissue. b. Colonies on dead branch. c-e. Conidiophores. f-h. Conidiophores with conidiogenous cells. i-t. Conidia. u. Germinated conidium. v. Culture on PDA. Scale bars: $\mathrm{a}=1 \mathrm{~cm}, \mathrm{~b}=1000 \mu \mathrm{m}, \mathrm{c}-\mathrm{h}=100 \mu \mathrm{m}, \mathrm{i}-\mathrm{u}=20 \mu \mathrm{m}$. 
Alternaria vitis Cavara, Atti Ist. bot. R. Univ. Pavia, 2 Sér. 1: 319 (1888)

Facesoffungi number: FOF03826

Saprotrophic on dead stems and roots of Vitis vinifera. Sexual morph: Not observed. Asexual morph: Conidiophores simple or branched, dark brown. Conidia 25-66 $\times 10-18 \mu \mathrm{m}$ $(\bar{x}=39 \times 15 \mu \mathrm{m}, \mathrm{n}=40)$, brown, usually producing single conidia, chains rarely observed, slightly verrucose, swollen at the base and gradually tapering towards end, apex filiform, lighter than the rest of the spores and ending in a straight false beak.

Culture characteristics - Colonies growing on PDA reaching $60 \mathrm{~mm}$ in 7 days at $25^{\circ} \mathrm{C}$, initially white colonies with cottony texture appear, later becoming greyish to dark olive brown, mycelium superficial, effuse, and radially striate, with irregular edge, sometimes sectoring can be observed.

Material examined - CHINA, Beijing, on dead root of Vitis vinifera cv. Red Globe, 3 June 2015, Ruvishika Jayawardena, culture MFLUCC 17-1109; CHINA, Beijing, on dead shoot of $V$. vinifera cv. Red Globe, 3 June 2015, Ruvishika Jayawardena, culture MFLUCC 17-1116.

Notes - Alternaria vitis is a well-known pathogen in grape growing regions due it causing fruit rots and leaf blights. Based on morphology, Zhang (2003) and Zhuang (2005) reported this species from China. In this study we identified this species as a saprotroph of $V$. vinifera based on morphology as well as sequence data.

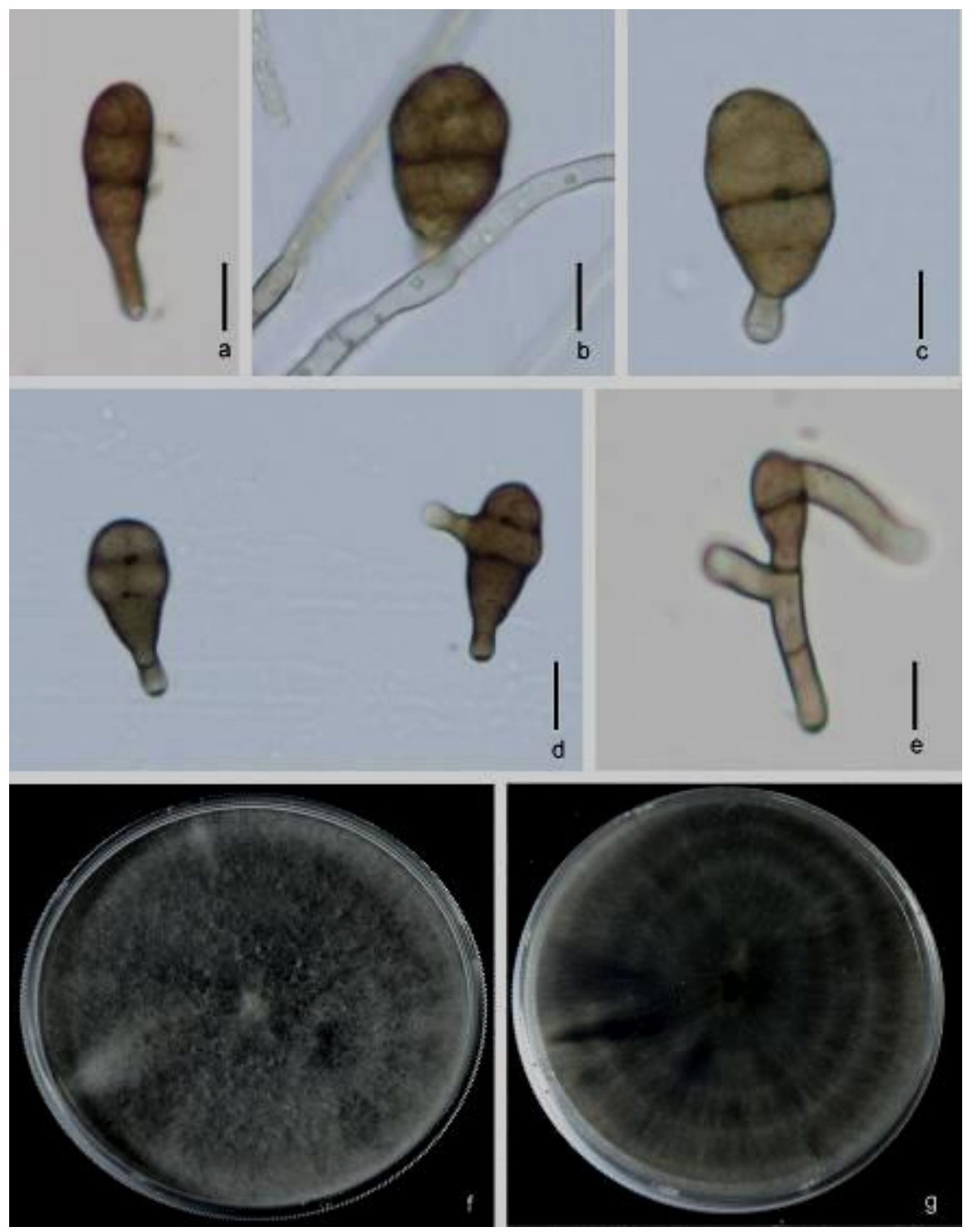

Fig. 35 - Alternaria vitis. a-d. Conidia. e. Conidiophore. f. Upper view of the culture on PDA. g. Reverse view of the culture on PDA. Scale bars: $\mathrm{a}-\mathrm{e}=20 \mu \mathrm{m}$. 
Bipolaris Shoemaker, Can. J. Bot. 37(5): 882 (1959)

Bipolaris was introduced by Shoemaker (1959) and it is considered an important plant pathogen associated with over 60 host genera (Manamgoda et al. 2011, Hyde et al. 2014). Our saprotrophic strains clustered with the type strain of $B$. maydis with a high bootstrap support in the phylogenetic analysis (Fig. 36).

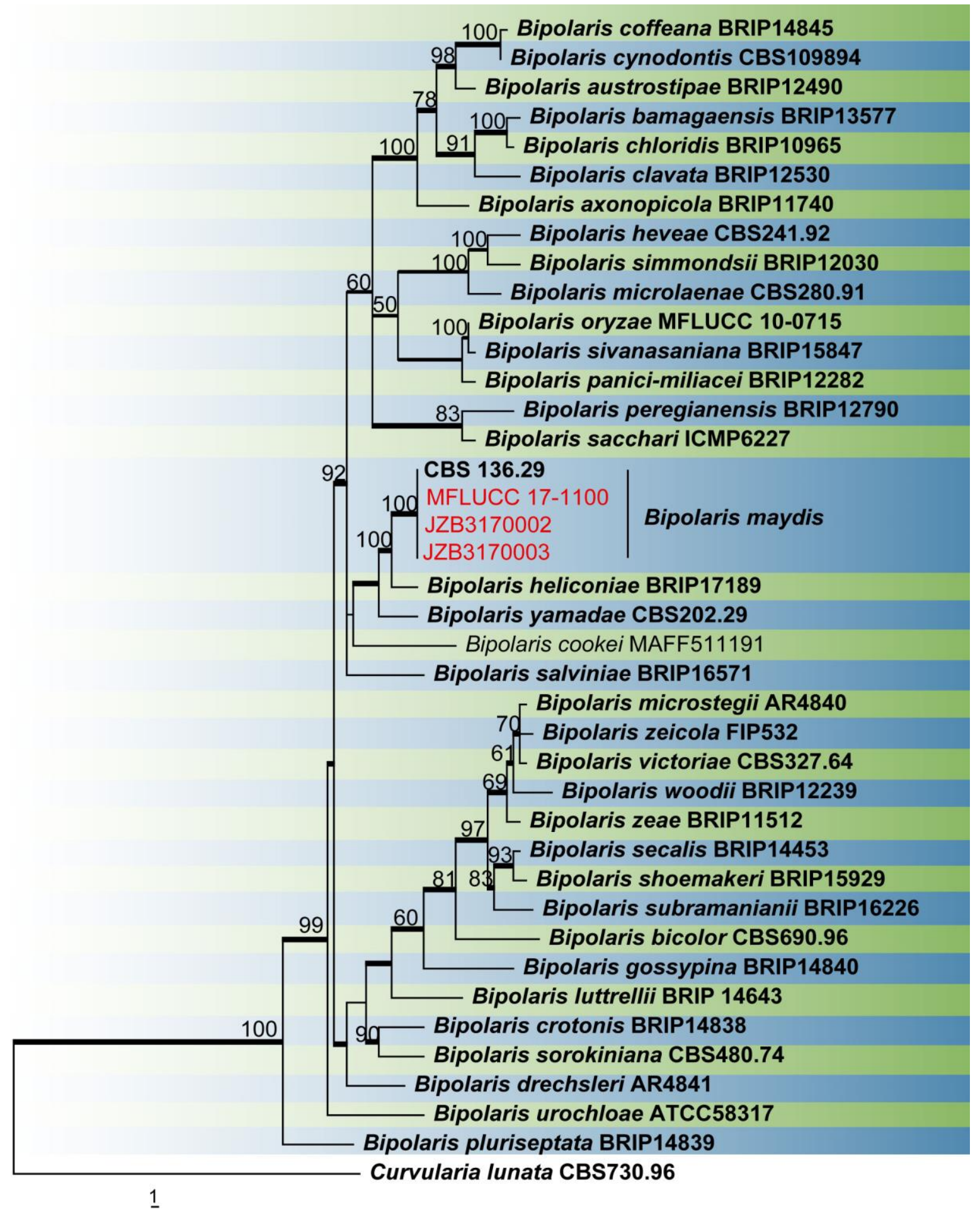

Fig. 36 - One of ten most parsimonious trees obtained from a heuristic search of combined ITS, and GAPDH sequence data of taxa of Bipolaris. Parsimony bootstrap support values $\geq 75 \%$ are indicated at the nodes and branches with Bayesian posterior probabilities $\geq 0.95$ given in bold. Extype strains are in bold. The tree is rooted with Curvularia lunata CBS 730.96. 
Bipolaris maydis (Y. Nisik. \& C. Miyake) Shoemaker, Can. J. Bot. 33: 882 (1959)

Facesoffungi No: FoF00504

Saprotrophic on dead shoots of Vitis vinifera. Sexual morph: Not observed. Asexual morph: Conidiophores $90-690 \times 5-7 \mu \mathrm{m}(\bar{x}=272 \times 5 \mu \mathrm{m}, \mathrm{n}=50)$, usually arising singly or in small groups, simple or rarely branched, septate, straight or flexuous, geniculate at upper part, olivaceous brown. Conidiogenous nodes dark brown, distinct. Conidia $60-150 \times 12-18 \mu \mathrm{m}(\bar{x}=94 \times 13 \mu \mathrm{m}$, $\mathrm{n}=40$ ), pale to mid dark brown, smooth, slightly curved, fusiform, distoseptate. Hilum distinct, 3-5 $\mu \mathrm{m}$ wide, germination tubes arising from both ends of conidia.

Cultural characteristics - Colonies on PDA reaching $70 \mathrm{~mm}$ in 7 days at $25^{\circ} \mathrm{C}$, greyish white when young, becoming blackish when mature.

Material examined - CHINA, Beijing, on dead shoots of Vitis vinifera cv. Red Globe, 3 June 2015, Ruvishika Jayawardena, culture MFLUCC 17-1100, JZB317002, JZB317003.

Notes - Bipolaris maydis is a well-known pathogen that causes Southern leaf blight in maize (Manamgoda et al. 2014). This study provides the first record of B. maydis on Vitis vinifera as well as a new record from China.
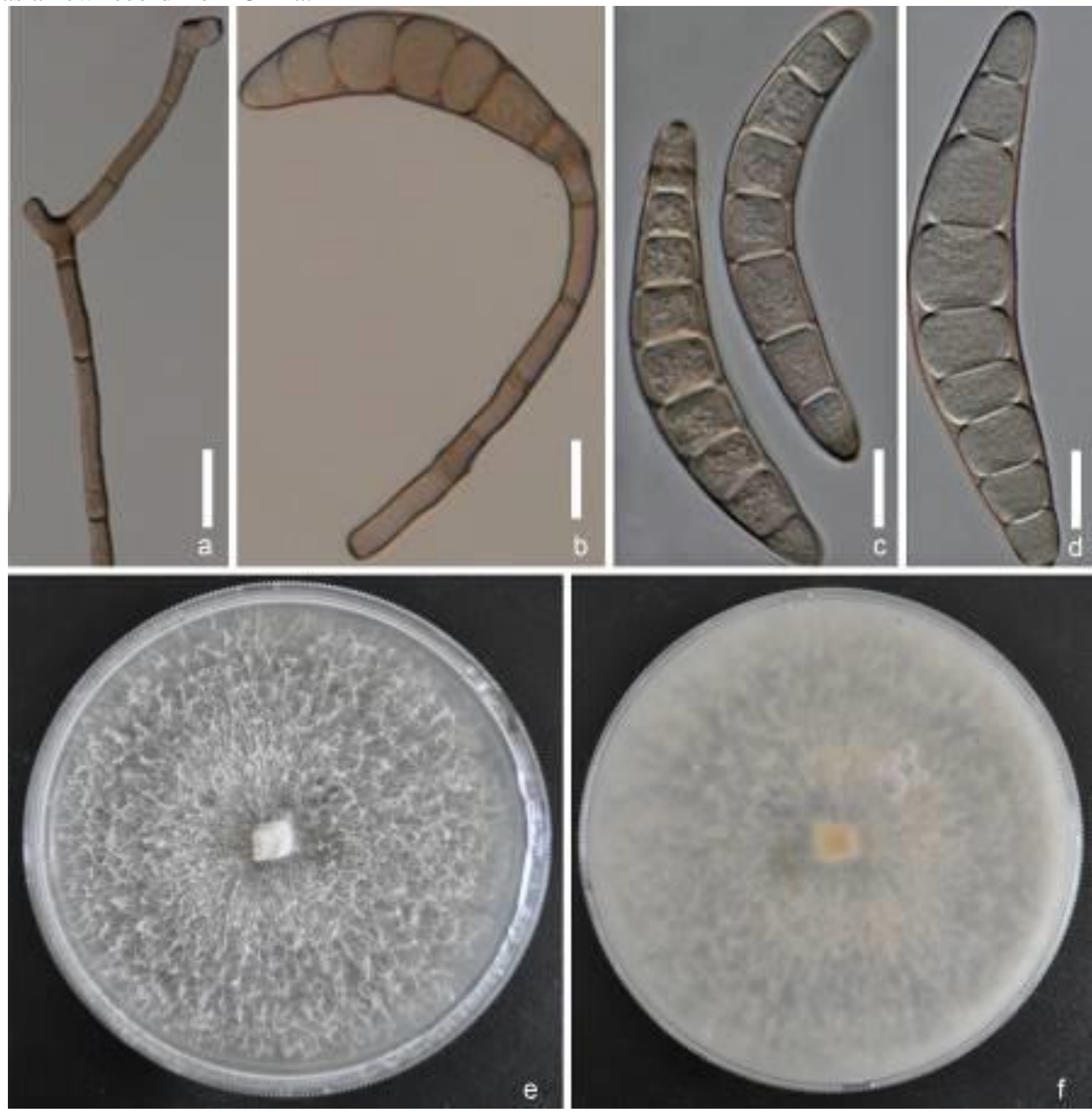

Fig. 37 - Bipolaris maydis. a-b. Conidiophores. c-d. Conidia. e. Surface view of colony on PDA. f. Reverse view of colony on PDA. Scale bars: $\mathrm{a}-\mathrm{d}=10 \mu \mathrm{m}$. 
Teichosporaceae M.E. Barr, Mycotaxon 82: 374 (2002)

This family was introduced by Barr (2002) to accommodate Teichospora Fuckel. Jaklitsch et al. (2016) provided the basis for the classification of this family and synonymized Floricolaceae Thambugala, Kaz. Tanaka \& K.D. Hyde.

Floricola Kohlm. \& Volkm.-Kohlm., Bot. Mar.43(4): 385 (2000)

Floricola was introduced as a monotypic genus by Kohlmeyer \& Volkmann-Kohlmeyer (2000) with $F$. striata JK5603K as the type species. Species of Floricola are saprotrophs with a cosmopolitan distribution (Thambugala et al. 2015). Jaklitsch et al. (2016) synonymized this genus under Teichospora. However, Wijayawardene et al. (2017) maintained Floricola as a distinct genus. There are only two epithets under this genus. Our strain clustered with the type strain of $F$. viticola in the multigene phylogenetic analysis (Fig. 38).

Floricola viticola Phukhams., Camporesi \& K.D. Hyde, in Ariyawansa et al., Fungal Diversity: 10.1007/s13225-015-0346-5, [45] (2015)

Facesoffungi number: FoF03822

Saprotrophic on dead and aerial branch of Vitis vinifera. Sexual morph: Not observed. Asexual morph: Conidiomata 220-239 $\times 154-202 \mu \mathrm{m}(\bar{x}=237 \times 177 \mu \mathrm{m}, \mathrm{n}=10)$ diam., solitary, pycnidial, unilocular, scattered, immersed to erumpent, subglobose, dark brown to black. Pycnidial wall 13-35 $\mu \mathrm{m}(-40 \mu \mathrm{m}$ at apex $)$, merging with host tissues externally, composed of brown cells of textura angularis with hyaline inner lining bearing conidiogenous cells. Conidiophores reduced to conidiogenous cells. Conidiogenous cells 2-10×2-9 $\mu \mathrm{m}(\bar{x}=4 \times 5 \mu \mathrm{m}, \mathrm{n}=20)$, enteroblastic, phialidic, determinate, solitary, doliiform, smooth-walled, hyaline. Conidia $7-12 \times 2-6 \mu \mathrm{m}(\bar{x}=9 \times 4$ $\mu \mathrm{m}, \mathrm{n}=50$ ), initially hyaline, dark brown at maturity, oblong, sub-fusiform, occasionally curved at the apex, with slight abscission scar at base, with 1-3-longitudinal septa, constricted at some septa, narrowly rounded at both ends, smooth-walled.

Cultural characters - Colonies on PDA $20 \mathrm{~mm}$ diam. after 4 weeks at $16{ }^{\circ} \mathrm{C}$, cream to orangish white at the margins; reverse white to cream and orangish white at the center, medium dense, circular, umbonate, fimbriate, fluffy, slightly radiating, without diffusible pigments.

Material examined - ITALY, Province of Forlì-Cesena, near Galeata, on dead and aerial branch of Vitis vinifera, 16 October 2014, E. Camporesi IT2178 (MFLU 15-1404), culture, MFLUCC 15-0039.

Notes - Floricola viticola has been recorded only from Italy as a saprotroph on Vitis vinifera.

\section{Sordariomycetes}

The class Sordariomycetes has been treated by Maharachchikumbura et al. $(2015,2016)$ and the taxonomic arrangements used by these authors and Wijayawardene et al. (2017) are followed here.

Amphisphaeriales D. Hawksw. \& O.E. Erikss., Syst. Ascom. 5(1): 177 (1986)

Sporocadaceae Corda, Icon. Fungorum (Prague) 5: 34.1842

Members of this family are endophytes and saprobes, as well as foliar pathogens (Nag Raj 1993). Maharachchikumbura et al. (2016) synonymized Discosiaceae under this family.

Neopestalotiopsis Maharachch., K.D. Hyde \& Crous, in Maharachchikumbura, Hyde, Groenewald, Xu \& Crous, Stud. Mycol. 79: 135 (2014)

Species of this genus can be easily distinguished by their versicolourous median cells (Maharachchikumbura et al. 2014). Strains in this study clustered together with the type strains of N. clavispora and N. vitis, respectively (Fig. 42). 


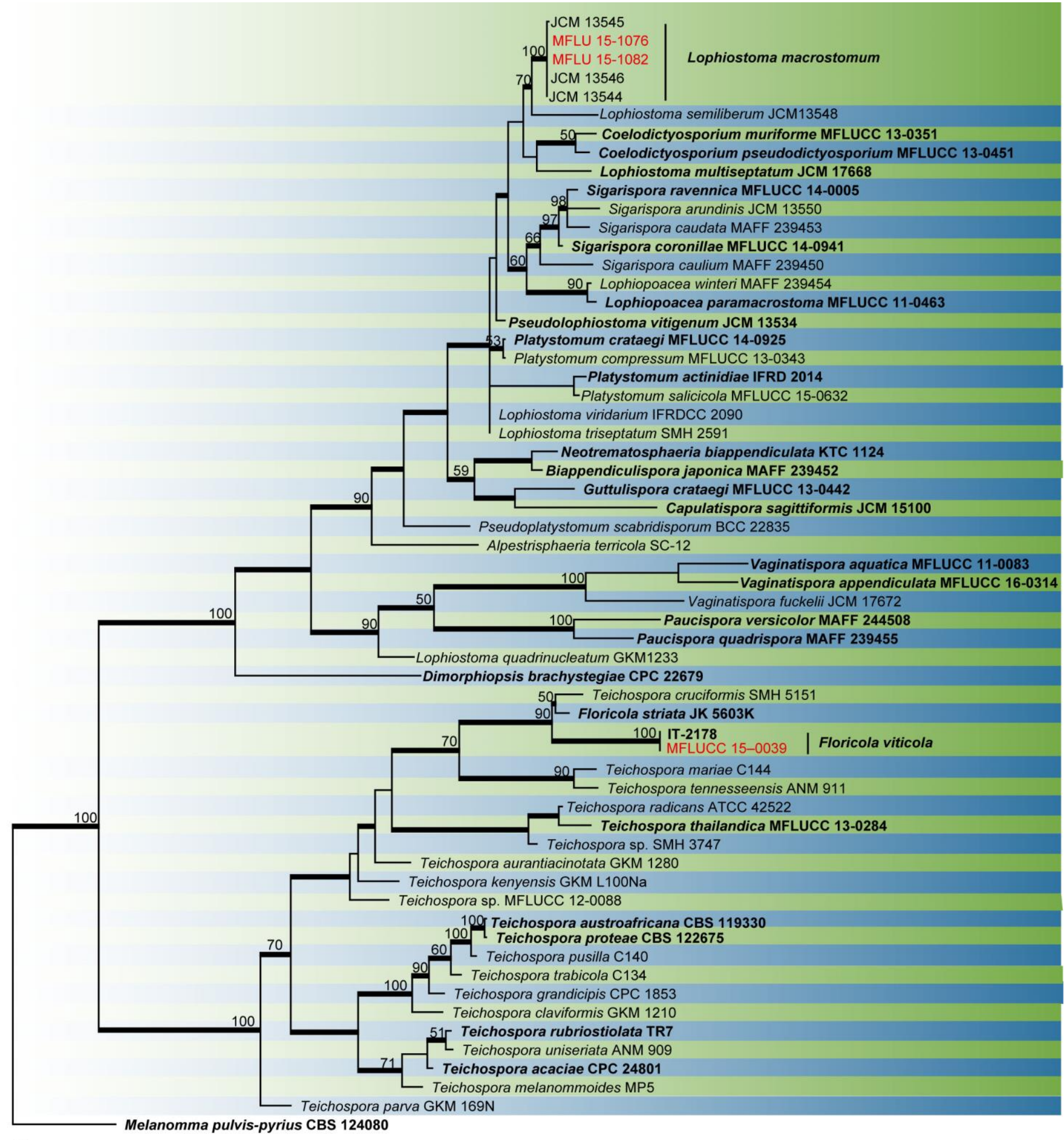

$\underline{10}$

Fig. 38 - RAxML phylogram obtained from the combined LSU, SSU ITS and TEF1 sequence data of species of Teichosporaceae and Lophiostomataceae. The species isolated in this study are shown in red. RAxML bootstrap support (BS) values $\geq 50 \%$ are shown at the nodes and branches with Bayesian posterior probability scores $\geq 0.90$ are given in bold. The tree is rooted with Melanomma pulvis-pyrius (CBS 124080). 

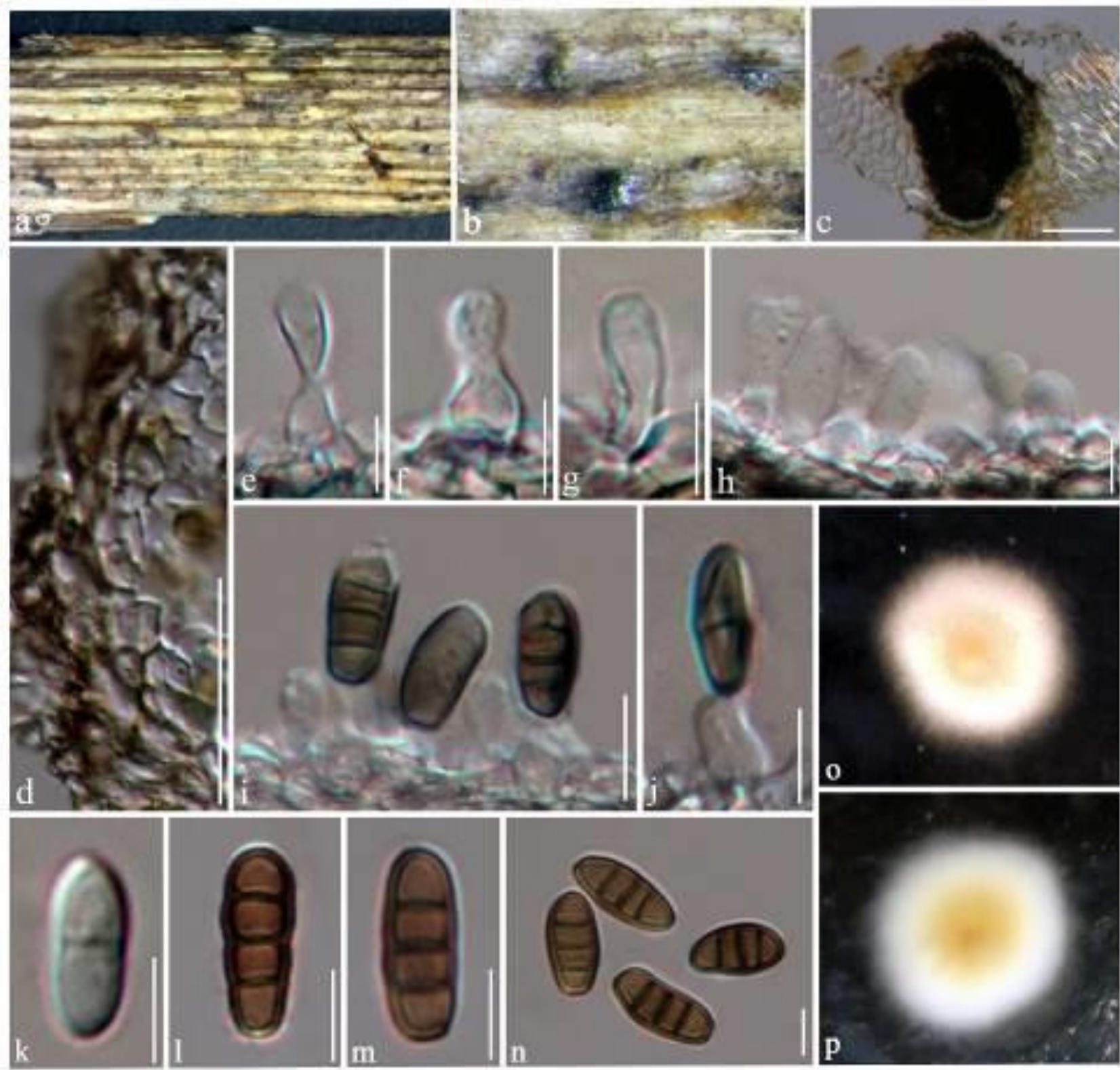

Fig. 39 - Floricola viticola. a. Fruiting bodies on host tissue. b. Close up of conidiomata below surface of host. c. Vertical section through conidioma. d. Part of peridium. e-j. conidiogenous cells with developing conidia. k-n. Conidia. o. Upper view of the culture on PDA. p. Reverse view of the culture on PDA Scale bars: $b=200 \mu \mathrm{m}, \mathrm{c}=100 \mu \mathrm{m}, \mathrm{d}=50 \mu \mathrm{m}, \mathrm{e}-\mathrm{n}=5 \mu \mathrm{m}$.

Neopestalotiopsis clavispora (G.F. Atk.) Maharachch., K.D. Hyde \& Crous, in Maharachchikumbura, Hyde, Groenewald, Xu \& Crous, Stud. Mycol. 79: 138 (2014)

Facesoffungi number: FoF 03819

Saprotrophic on root and shoots of Vitis vinifera. Sexual morph: Not observed. Asexual morph: Conidiomata pycnidial in culture on PDA, 150-250 $\mu \mathrm{m}$ in diam., black, numerous, scattered. Conidia 18-26×6-8 $\mu \mathrm{m}(\bar{x}=21 \times 8 \mu \mathrm{m}, \mathrm{n}=40)$, fusiform, 4-septate, straight or slightly curved; basal cell long and conic, hyaline, thin and verruculose, with three median cells $13-15 \mu \mathrm{m}$ long, dark brown to olivaceous, septa and periclinal walls darker than the rest of the cell, versicoloured, second cell from base pale brown, 4-5 $\mu \mathrm{m}$ long; third cell darker brown, 5-7 $\mu \mathrm{m}$ long; fourth cell darker, 5-6 $\mu \mathrm{m}$ ?long; apical cell 3-4 $\mu \mathrm{m}$ long, short, broad conic, hyaline, subcylindric; with 2-3 (rarely 2) apical appendages, 19-30 $\mu \mathrm{m}$ long, tubular, ; with basal, filiform appendage. 
Culture characteristics - Colonies on PDA reaching $70 \mathrm{~mm}$ after 7 days at $25^{\circ} \mathrm{C}$, edge undulate, whitish, aerial mycelium on surface, fruiting bodies black, concentric; reverse pale luteous.

Material examined - CHINA, Beijing, on dead shoot of Vitis vinifera cv. Red Globe, 3 June 2015, Ruvishika Jayawardena, culture, MFLUCC 17-1117, MFLUCC 17-1120, MFLUCC 35, JZB340031, JZB340033 and JZB340034; CHINA, Beijing, on dead root of $V$. vinifera cv. Red Globe, 3 June 2015, Ruvishika Jayawardena, culture, JZB340032.

Notes - Neopestalotiopsis clavispora is known as a saprotroph on Magnolia sp. and Quercus rubra (Maharachchikumbura et al. 2014). This study provides the first record of $N$. clavispora on Vitis vinifera.

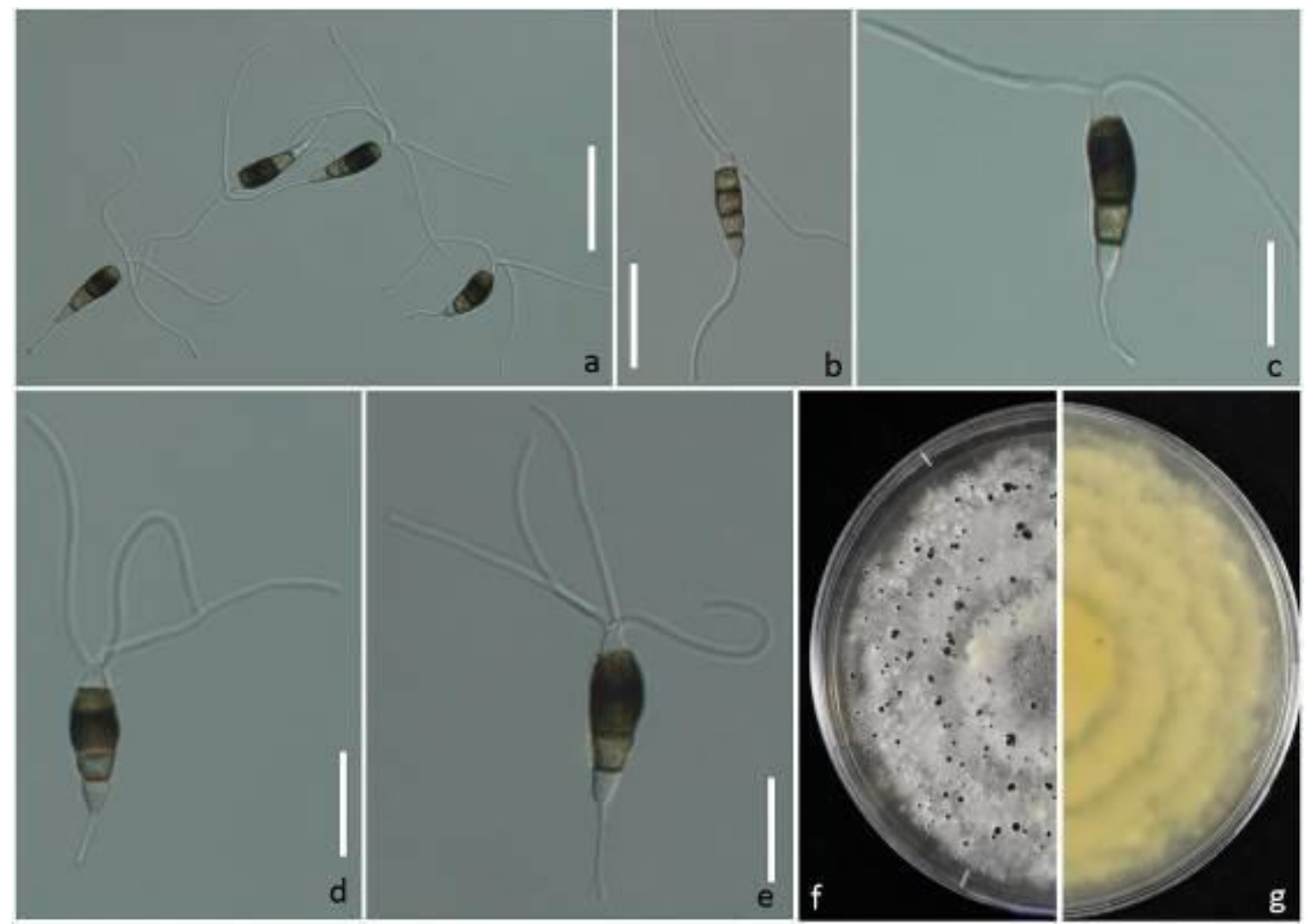

Fig. 40 - Neopestalotiopsis clavispora. a-e. Conidia. f. Upper view of the colony g. Reverse view of the colony. Scale bars a-e $=10 \mu \mathrm{m}$.

Neopestalotiopsis vitis Jayawardena, Maharachch., Yan, Li \& Hyde, in Jayawardena, Liu, Maharachchikumbura, Zhang, Xing, Hyde, Nilthong, Li \& Yan, Phytotaxa 258(1): 69 (2016)

Facesoffungi number: FoF01110

Saprotrophic on dead bark, root and shoots of Vitis vinifera. Sexual morph: Not observed. Asexual morph: Conidiomata pycnidial in culture on PDA, globose to oval, solitary or aggregated in clusters, semi-immersed, black, $120-550 \mu \mathrm{m}$ diam.; exuding globose, black, glistening, conidial masses. Conidiophores indistinct, often reduced to conidiogenous cells. Conidiogenous cells discrete, fusiform, hyaline, cylindrical to subcylindrical or ampulliform to lageniform, rugosewalled, simple, 2-11 $\times 1-5 \mu \mathrm{m}$. Conidia fusoid, ellipsoid, straight to slightly curved, 4-septate, 20$28 \times 5-10 \mu \mathrm{m}(\bar{x}=22 \times 7 \mu \mathrm{m}, \mathrm{n}=40)$; basal cell conic to acute with a truncate base, hyaline, rugose, thin-walled, 3-7 $\mu \mathrm{m}$ long, three median cells, doliiform, 13-18 $\mu \mathrm{m}$ long, wall rugose, versicoloured, septa darker than the rest of the cell, somewhat constricted at the septa; second cell from base pale brown to olivaceous, 4-6 $\mu \mathrm{m}$ long; third cell olivaceous to darker brown, 4-7 $\mu \mathrm{m}$ long; fourth cell brown, 4-6 $\mu \mathrm{m}$ long; apical cell 3-5 $\mu \mathrm{m}$ long, hyaline, cylindrical to subcylindrical, thin and smooth walled, with 2-4 tubular apical appendages (mostly 3), arising from 
the apical crest, flexuous, unbranched, 12-45 $\mu \mathrm{m}$ long, basal appendage 1-2, tubular, unbranched, centric, $2-7 \mu \mathrm{m}$ long.

Culture characteristics - Colonies on PDA reaching 50-60 $\mathrm{mm}$ in diam. after 7 days at 25 ${ }^{\circ} \mathrm{C}$, with lobate edge, whitish to pale honey coloured, with dense aerial mycelium on the surface with black, concentric conidiomata, reverse pale yellow.

Material examined - CHINA, Beijing, on dead bark of Vitis vinifera cv. Red Globe, 3 June 2015, Ruvishika Jayawardena, culture, MFLUCC 17-1108, JZB340029; CHINA, Beijing, on dead shoots of $V$. vinifera cv. Red Globe, 3 June 2015, Ruvishika Jayawardena, culture, MFLUCC 171108 , JZB340027, JZB340028;. CHINA, Beijing, on dead roots of V. vinifera cv. Red Globe, 3 June 2015, Ruvishika Jayawardena, culture, JZB340030. CHINA, Yunnan, on dead shoots of Vitis vinifera cv. CarbanateGernischet, 11 June 2015, XH. Li, culture, MFLUCC 17-1167.

Notes - Jayawardena et al. (2016a) introduced $N$. vitis to accommodate a pathogen that causes leaf spot, fruit rots and cankers of grapevine in China. This study provides the first record of this species as a saprotroph on V. vinifera.
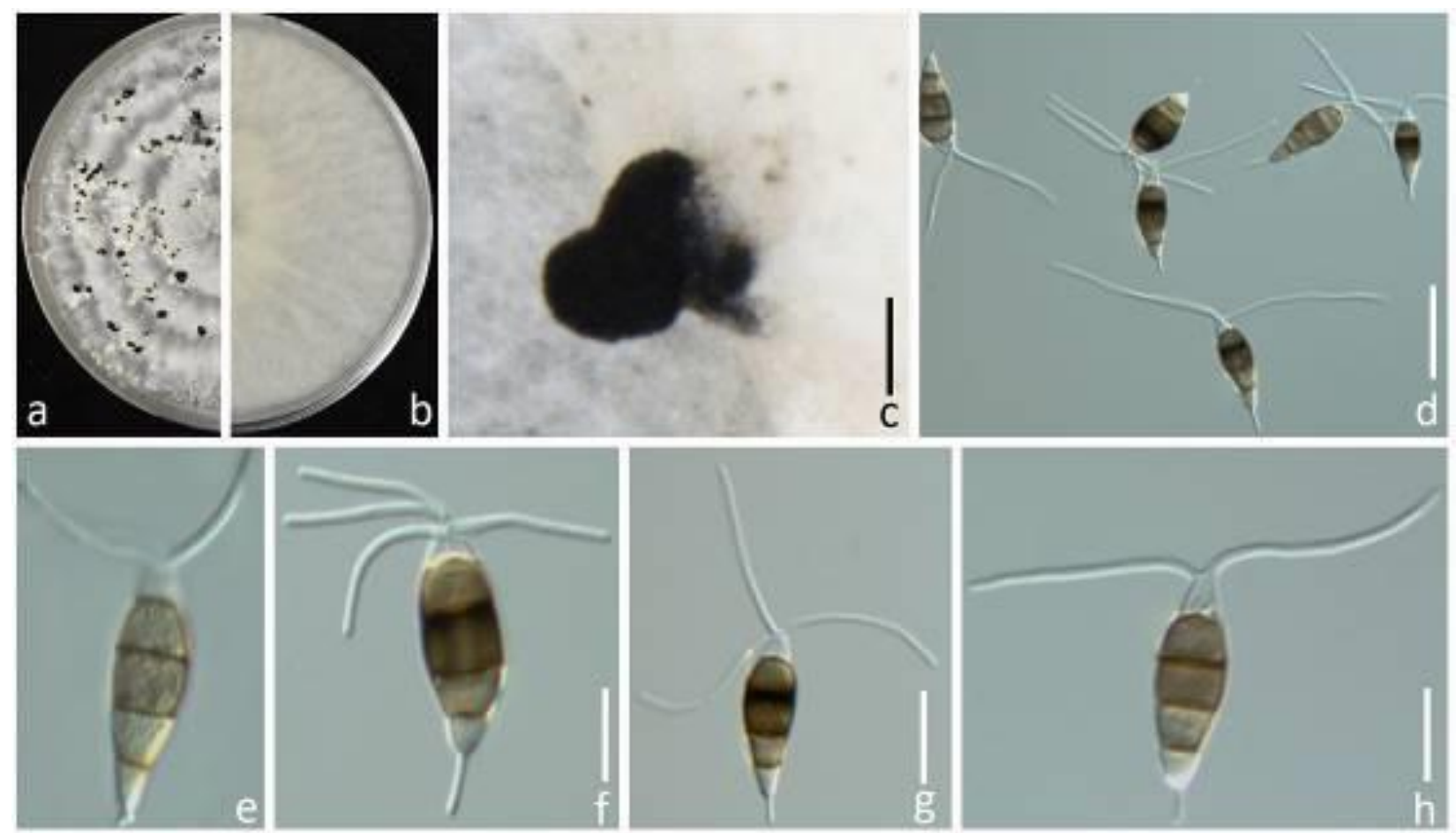

Fig. 41 - Neopestalotiopsis vitis. a. Upper view of the colony b. Reverse view of the colony. c. Black exude on PDA. d-h. Conidia. Scale bars: $d-h=10 \mu \mathrm{m} c=100 \mu \mathrm{m}$.

Pestalotiopsis Steyaert, Bull. Jard. bot. État Brux. 19: 300 (1949)

Pestalotiopsis was introduced to accommodate species with 5-celled conidia and has been relatively well-studied (Maharachchikumbura et al. 2012, 2014). Species of this genus have been often isolated as endophytes (Maharachchikumbura et al. 2011, 2012). In this study we provide accounts for P. chamaeropis and a Pestalotiopsis sp., based on morphology and phylogenetic analysis (Fig. 45).

Pestalotiopsis chamaeropis Maharachch., K.D. Hyde \& Crous, in Maharachchikumbura, Hyde, Groenewald, Xu \& Crous, Stud. Mycol. 79: 158 (2014)

Facesoffungi number: FoF03818

Saprotrophic on dead branch of Vitis vinifera. Sexual morph: Not observed. Asexual morph: Coelomycetous. Conidiomata 140-210 $\mu \mathrm{m}$ diam., 85-100 $\mu \mathrm{m}$ high, slightly raised, black, solitary to aggregated, semi-immersed, becoming erumpent at maturity, pycnidioid, globose to 


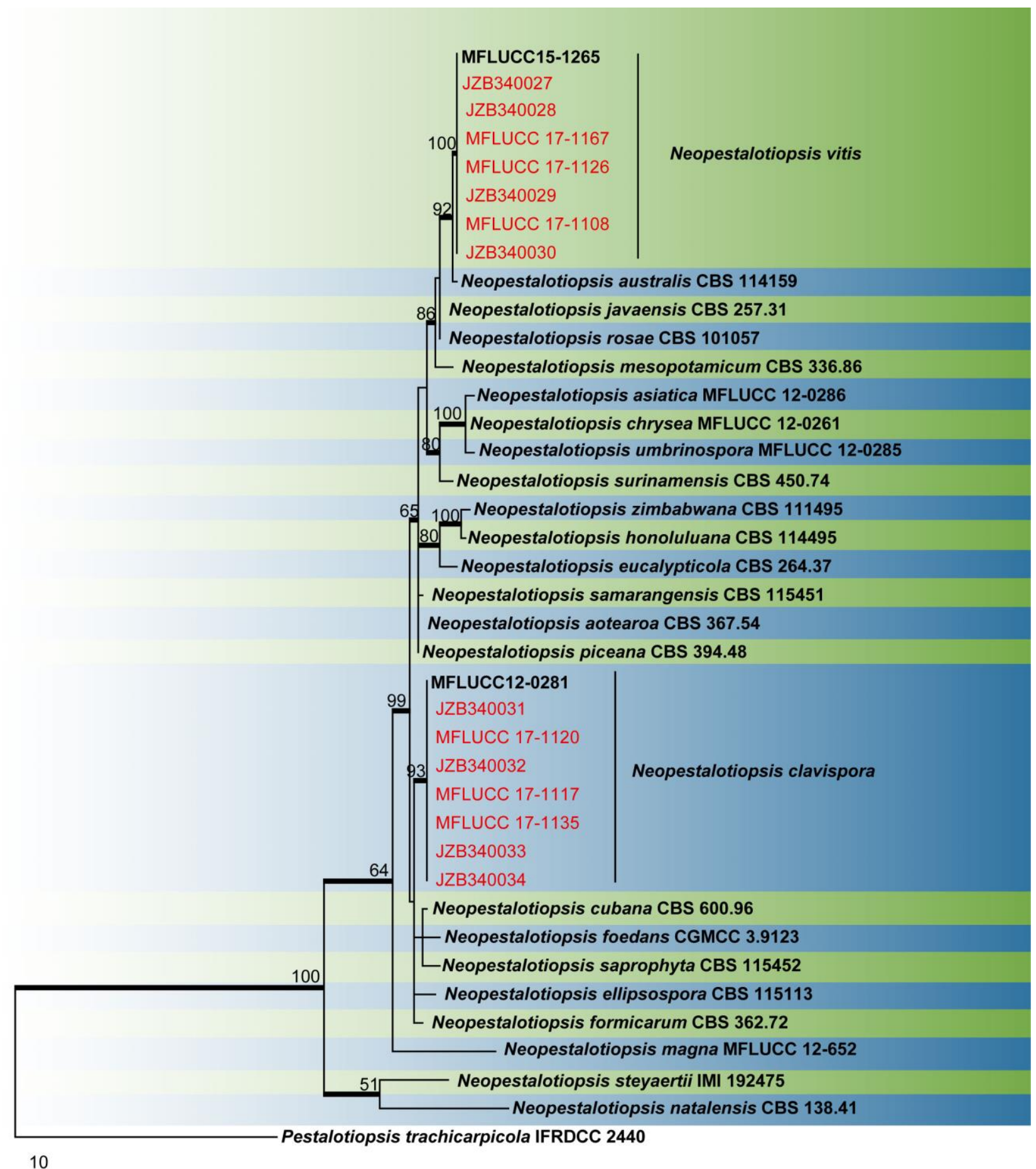

Fig. 42 - One of eight most parsimonious trees obtained from a heuristic search of combined ITS, TUB2 and TEF1 sequence data of taxa of Neopestalotiopsis. Parsimony bootstrap support values $\geq$ $50 \%$ are indicated at the nodes and branches with Bayesian posterior probabilities $\geq 0.90$ given in bold. Ex-type strains are in bold. Strains obtained in this study are in red. The tree is rooted with Pestalotiopsis trachicarpicola IFRDCC 2440.

subglobose, unilocular, glabrous. Conidiomata wall 8-15 $\mu \mathrm{m}$ wide, composed of thin-walled, outer, light brown cells of textura prismatica and inner, hyaline cells of textura angularis to textura globulosa. Conidiophores reduced to conidiogenous cells. Conidiogenous cells 6-13 $\mu \mathrm{m}$ long, 1-4 $\mu \mathrm{m}$ wide, hyaline, enteroblastic, subcylindrical, arising from the cells lining the inner wall of the pycnidium. Conidia $20-30 \times 8-10 \mu \mathrm{m}(\bar{x}=25 \times 8 \mu \mathrm{m}, \mathrm{n}=50)$, fusiform, 4-septate, straight or slightly curved, bearing tubular, unbranched, flexuous appendages at both ends, basal cell $3-5 \mu \mathrm{m}(\bar{x}=4$ 
$\mu \mathrm{m})$ long, hyaline, cuneiform, 3 median cells, together 15-20 $\mu \mathrm{m}$ long (second cell from base 4-7 $\mu \mathrm{m}(\bar{x}=5 \mu \mathrm{m})$, third cell 4-7 $\mu \mathrm{m}(\bar{x}=6 \mu \mathrm{m})$, fourth cell 4-7 $\mu \mathrm{m}(\bar{x}=5 \mu \mathrm{m}))$, cylindrical to doliiform, medium brown to dark brown and mostly concolourous, third cell from base darker in mature conidia at times, septa and periclinal walls thicker, apical cell 3-5 $\mu \mathrm{m}(\bar{x}=4 \mu \mathrm{m})$ long, hyaline, conical, with 4(-5) apical appendages, 5-20 $\mu \mathrm{m}(\bar{x}=11 \mu \mathrm{m})$ long, with independent loci of origin at apical end of the cell, basal appendage $2-5 \mu \mathrm{m}(\bar{x}=4 \mu \mathrm{m})$ long, single, eccentric, unbranched.

Material examined - ITALY, Province of Forlì-Cesena, San Lorenzo in Noceto - Forlì on dead aerial branch of Vitis vinifera, 29 April 2014, Erio Camporesi, IT 1838 (MFLU 15-0794).

Notes - A culture is not available for this species. Therefore, sequencing was carried out using fruiting bodies. This species is only known from leaves of Chamaerops humilis from Italy. This study provides the first record of $P$. chamaeropis as a saprotroph on $V$. vinifera.
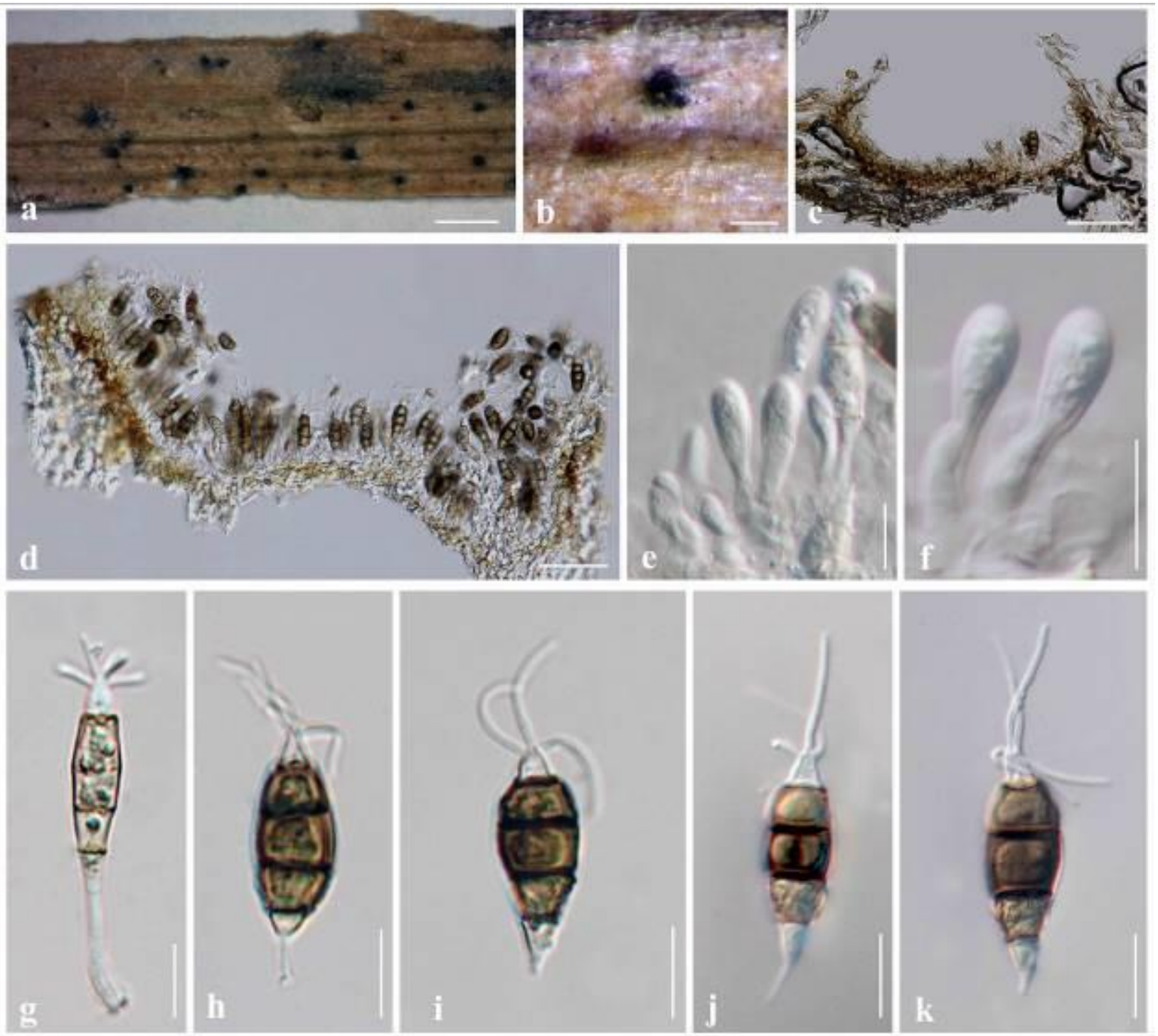

Fig. 43 - Pestalotiopsis chamaeropis. a. Appearance of conidiomata on host surface. b. Close up of a conidioma. $\mathrm{c}$, d. Vertical sections through conidiomata. e, f. Conidia arising from conidiogenous cells. g-k. Conidia. Scale bars: $\mathrm{a}=1000 \mu \mathrm{m}, \mathrm{b}=200 \mu \mathrm{m}, \mathrm{c}, \mathrm{d}=50 \mu \mathrm{m}, \mathrm{e}-\mathrm{k}=10 \mu \mathrm{m}$.

\section{Pestalotiopsis sp.}

Facesoffungi number: FoF 03879

Saprotrophic on dead and aerial branches of Vitis vinifera. Sexual morph: Not observed. Asexual morph: Conidiomata 88-118 $\mu \mathrm{m}$ high, 99-163 $\mu \mathrm{m}$ diam. $(\bar{x}=100 \times 129 \mu \mathrm{m}, \mathrm{n}=5)$, gregarious to scattered, semi-immersed to erumpent through the host surface, sub-globose to 
ampulliform, dark brown to black, unilocular, pycnidial, ostiole central with distinct papilla. Pycnidial wall 15-21 $\mu \mathrm{m}$, thick-walled with equal thickness, composed of 6-7 layers of pseudoparenchymatous cells, outer layer with thick-walled dark brown to black, textura angularis to textura globose, inner layer with thin-walled light brown to hyaline textura angularis to textura prismatica. Conidiophores reduced to conidiogenous cells. Conidiogenous cells $4-7 \times 2-3 \mu \mathrm{m}$ $(\bar{x}=5 \times 2 \mu \mathrm{m}, \mathrm{n}=10)$, discrete, cylindrical, swollen at the base, hyaline, smooth, thin-walled, producing a single conidium at the apex. Conidia $24-28 \times 8-10 \mu \mathrm{m}(\bar{x}=26 \times 9 \mu \mathrm{m}, \mathrm{n}=20)$, fusoid, ellipsoid, straight to slightly curved, 4-septate; basal cell conic with a truncate base, hyaline, rugose and thin-walled, 3-6 $\mu \mathrm{m}$ long; three median cells doliiform, 16-20 $\mu \mathrm{m}$ long $(\bar{x}=17 \mu \mathrm{m})$, wall verruculose, concolourous, olivaceous, (second cell from the base 4-7 $\mu \mathrm{m}(\bar{x}=5 \mu \mathrm{m})$; third 5-7 $\mu \mathrm{m}$ $(\bar{x}=6 \mu \mathrm{m})$; fourth cell 4-7 $\mu \mathrm{m}(\bar{x}=5 \mu \mathrm{m})$; apical cell 3-5 $\mu \mathrm{m}(\bar{x}=4 \mu \mathrm{m})$ long, hyaline, sub-cylindrical, rugose and thin-walled; with 4-5 tubular apical appendages, arising from the apical crest, unbranched, filiform, flexuous, 9-23 $\mu \mathrm{m}$ long $(\bar{x}=17 \mu \mathrm{m})$; basal appendage single, tubular, unbranched, centric, $4-9 \mu \mathrm{m}(\bar{x}=6 \mu \mathrm{m})$ long.
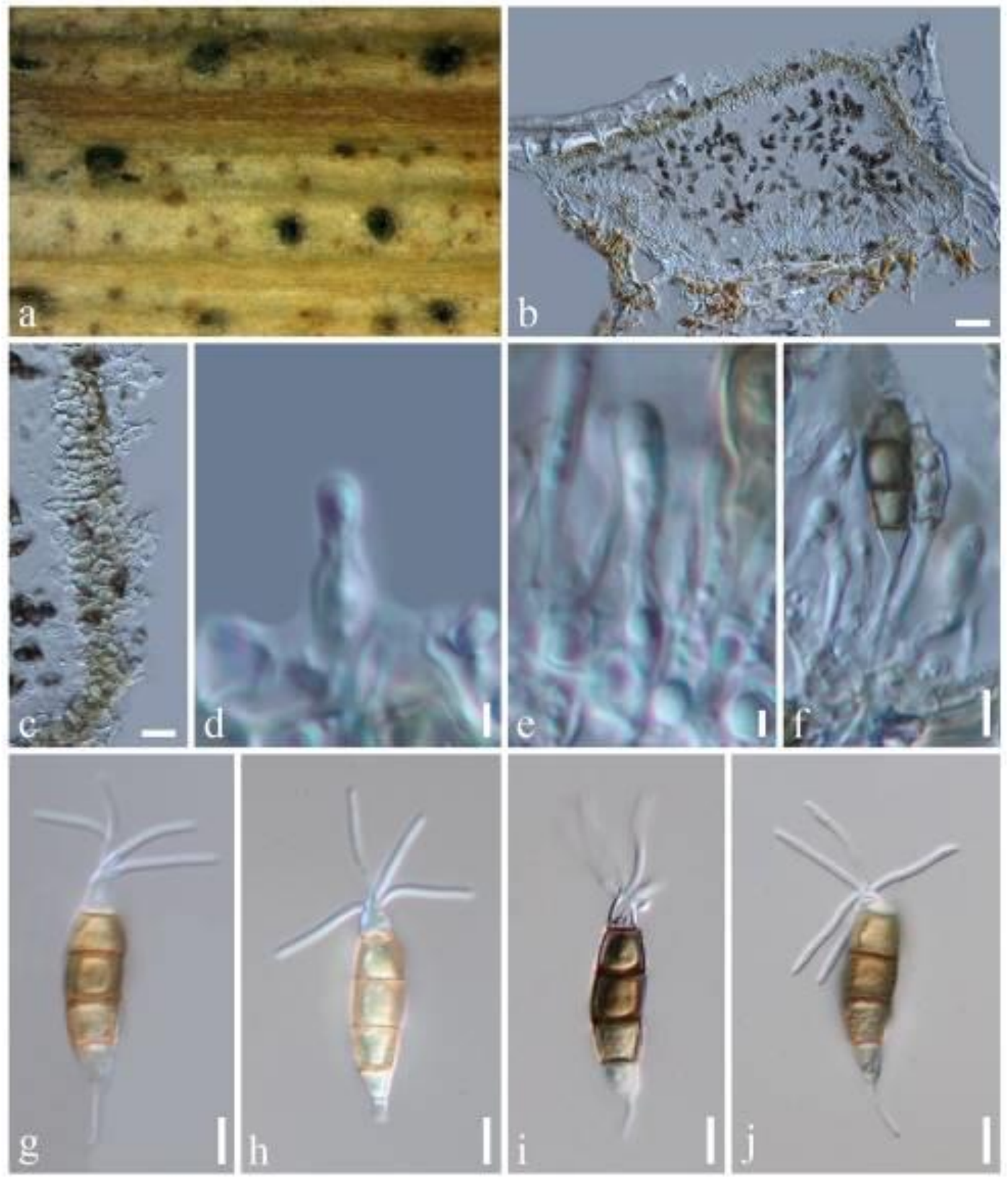

Fig. 44 - Pestalotiopsis sp. a. Appearance of conidioma on host surface. b. Longitudinal section of conidioma. c. Peridium. d-f. Conidiogenous cells. g-j Conidia. Scale bars: $b=50 \mu \mathrm{m}, \mathrm{c}-\mathrm{e}=20 \mu \mathrm{m}, \mathrm{f}-$ $\mathrm{j}=10 \mu \mathrm{m}$. 


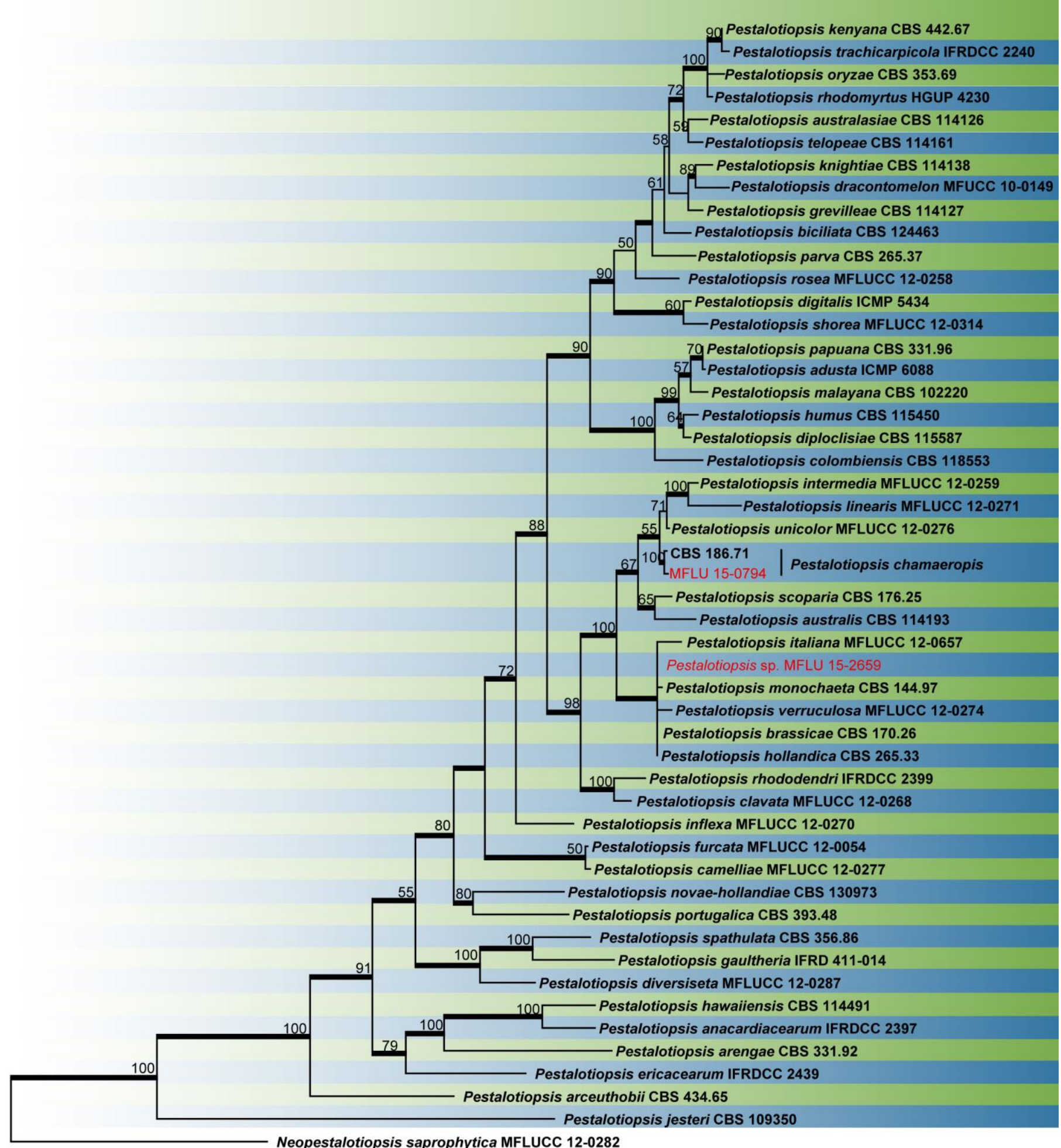

$\underline{10}$

Fig. 45 - One of the ten most parsimonious trees obtained from a heuristic search of combined ITS, TUB2 and TEF1 sequence data of taxa of Pestalotiopsis. Parsimony bootstrap support values $\geq 50$ $\%$ are indicated at the nodes and branches with Bayesian posterior probabilities $\geq 0.90$ given in bold. Ex-type strains are in bold. Strains obtained in this study are in red. The tree is rooted with Neopestalotiopsis saprophytica MFLUCC 12-0282. 
Material examined - ITALY, Province of Forlì-Cesena, San Lorenzo in Noceto- Forlì, on dead and aerial branch of Vitis vinifera, 29 April 2014, Camporesi Erio (MFLU 15-2659).

Notes - Several species of Pestalotiopsis have been recorded to be associated with $V$. vinifera in grape growing regions (Nag Raj 1993, Jayawardena et al. 2015, Maharachchikumbura et al. 2016b). Only ITS sequence data is available for this species, and in our phylogenetic tree it is placed in the clade with $P$. italiana, $P$. monochaeta, $P$. verruculosa, $P$. brassicae and $P$. hollandica. Due to the lack of protein coding regions that are useful for better resolution in Pestalotiopsis, we decided to keep it as an un-named Pestalotiopsis sp.

Pseudopestalotiopsis Maharachch., K.D. Hyde \& Crous, in Maharachchikumbura, Hyde, Groenewald, Xu \& Crous, Stud. Mycol. 79: 180 (2014)

This genus was introduced to accommodate species with dark concolorous median cells and knobbed apical appendages (Maharachchikumbura et al. 2014). Combined gene phylogenetic analysis showed that our strain belongs with P. camelliae-sinensis (Fig. 47).

Pseudopestalotiopsis camelliae-sinensis F. Liu \& L. Cai, Scientific Reports 7: 866: 12 (2017) Facesoffungi number: FoF 01629

Saprotrophic on dead and aerial branch of Vitis vinifera. Sexual morph: Not observed. Asexual morph: Conidiomata pycnidial in culture on PDA, globose or clavate, aggregated, dark brown to black, up to $500 \mu \mathrm{m}$ diam; exuding globose, dark brown to black conidial masses. Conidiophores reduced to conidiogenous cells. Conidiogenous cells discrete or integrated, ampulliform, subcylindrical or nearly globose, hyaline, smooth or minutely verruculose, $9-18 \times 3-6$ $\mu \mathrm{m}$. Conidia fusoid, ellipsoid, straight to slightly curved, 4-septate, $25-34 \times 6-9 \mu \mathrm{m}(\bar{x}=28 \times 8 \mu \mathrm{m}$, $\mathrm{n}=40$ ); basal cell conic or obconic with a truncate base, hyaline, rugose and thin-walled, 3-6 $\mu \mathrm{m}$ long; three median cells doliiform or subcylindrical, 16-19 $\mu \mathrm{m}$ long, verruculose, concoloured, septa darker than the rest of cell and conidium constricted at septa; second cell from base, 5-8 $\mu \mathrm{m}$

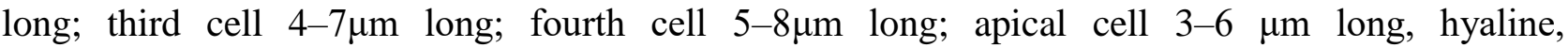
subcylindrical or obconic with a truncate base, thin-walled, slightly rugose; with 2-3 tubular apical appendages ( rarely 4), arising from the apical crest, unbranched, filiform, 24-53 $\mu \mathrm{m}$ long; basal appendage single, tubular, centric or uncentred, 6-9 $\mu \mathrm{m}$ long.

Culture characteristics - Colonies on PDA attaining 70-80 mm diam after 7 days at $25^{\circ} \mathrm{C}$, with lobate edge, whitish to pale honey-coloured, reverse whitish to pale honey.

Material examined - ITALY, Province of Forlì-Cesena, near Teodorano - Meldola, on dead aerial branch of Vitis vinifera, 15 February 2015, Erio Camporesi, IT 2380 (MFLU 15-0372), culture MFLUCC 17-1220 (KUMCC 17-0064).

Notes - Maharachchikumbura et al. (2016) proposed Ps. camelliae nomenclaturally as $P S$. ignota, but in other parts of the same paper cited it as Ps. camelliae. Therefore, the name Ps. camelliae is considered as invalid. Liu et al. (2017) described a new species named Ps. camelliaesinensis and our isolate clusters together with the type species of this new species. This study provides the first record of Ps. camelliae-sinensis as a saprotroph on $V$. vinifera.

Seimatosporium Corda, in Sturm, Deutschl. Fl., 3 Abt. (Pilze Deutschl.) 3(13): 79 (1833)

Seimatosporium was introduced by Corda (1833) based on $S$. rosae. Species of this genus are known to be saprotrophs. Strains in this study clustered together with the type strain of $S$. vitis (Fig. 48).

Seimatosporium vitis Y.P. Xiao, Camporesi \& K.D. Hyde, in Senanayake et al., Fungal Diversity 73: $102(2015)$

Facesoffungi number: FoF02938

Saprobic on dead and aerial branch of Vitis vinifera. Sexual morph: Not observed. Asexual morph: Conidiomata $290-542 \mu \mathrm{m}$ diam. $(\bar{x}=466 \mu \mathrm{m}, \mathrm{n}=10)$, solitary or gregarious, semi-immersed, elongate to rounded, dark brown to black. Pycnidial wall light brown, thin-walled cells of textura 
angularis. Conidiophores reduced to conidiogenous cells. Conidiogenous cells $15-32 \times 1-3 \mu \mathrm{m}$ $(\bar{x}=20 \times 2 \mu \mathrm{m}, \mathrm{n}=20)$, holoblastic, cylindrical, hyaline to pale brown, smooth-walled. Conidia 12 $18 \times 2-7 \mu \mathrm{m}(\bar{x}=15 \times 5 \mu \mathrm{m}, \mathrm{n}=40)$, ellipsoid or fusiform, straight or slightly curved, pale to dark brown, smooth-walled, 3-septate, constricted at septa, guttulate, apical cells conical with acutely rounded apex, base cells obconical, rounded at the base, bearing appendage at both ends. Appendages 7-14 $\mu \mathrm{m}(\bar{x}=11 \mu \mathrm{m}, \mathrm{n}=40)$, central or eccentric, single, unbranched, cylindrical, occur at both ends.

Culture characteristics - Colonies on PDA, circular, flat, entire-edged, dark brown centre on the surface, with white to smoke grey margin, dark brown centre on reverse, with grey olivaceous to white near the margin, reaching $8 \mathrm{~cm}$ diam. after 2 weeks at $20^{\circ} \mathrm{C}$.

Material examined - ITALY, Province of Forlì-Cesena, Via Nenni - Forlì, on dead and aerial branch of Vitis vinifera, 9 March 2016, Erio Camporesi (MFLU 16-0998), culture MFLUCC 17-1060; ITALY, Province of Forlì-Cesena, Meldola, Teodorano, on dead and aerial branch of $V$. vinifera, 14 February 2015, Erio Camporesi, IT2377 (MFLU 15-0204).

Notes - The first Seimatosporium species identified from Vitis was Seimatosporium vitis (Senanayake et al. 2015). According to our phylogenetic analyses of combined LSU and ITS sequence data (Fig. 47), our isolates clade together with the type species of S. vitis (MFLUCC 140052) with relatively high bootstrap and Bayesian probabilities (99\% MP/ $1.00 \mathrm{PP}$ ). However, our isolate deviates from the type species by having larger conidiomata, smaller conidia, and by having appendages at both ends (Senanayake et al. 2015). Since phylogenetic evidence does not support our isolate to be a new species, we determine our isolate as Seimatosporium vitis.
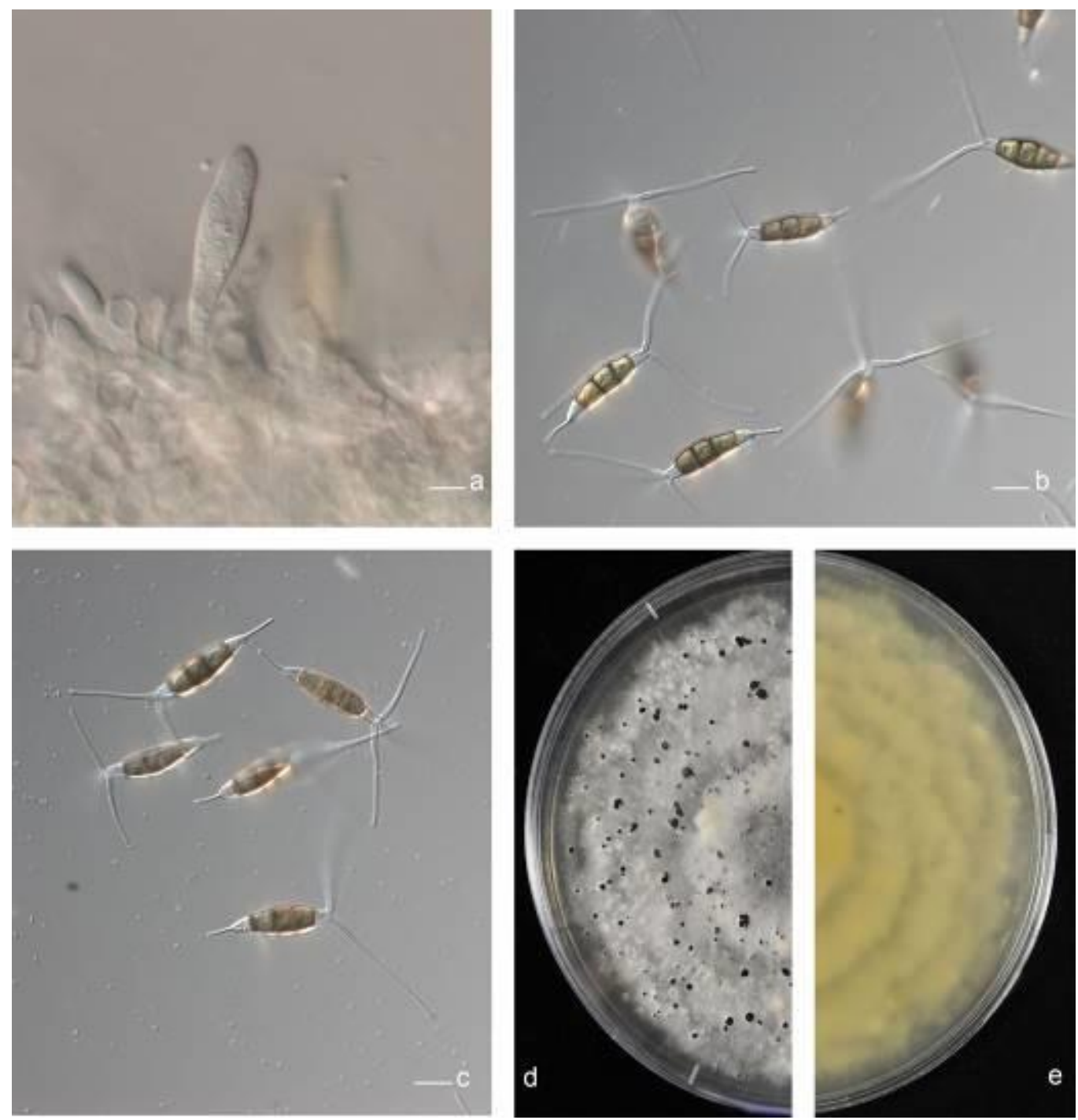

Fig. 46 -Pseudopestalotiopsis camelliae-sinensis. a. Conidiogenous cells. b-c. Conidia. d. Upper view of the colony. e. Reverse view of the colony. Scale bars: $a-c=20 \mu \mathrm{m}$. 


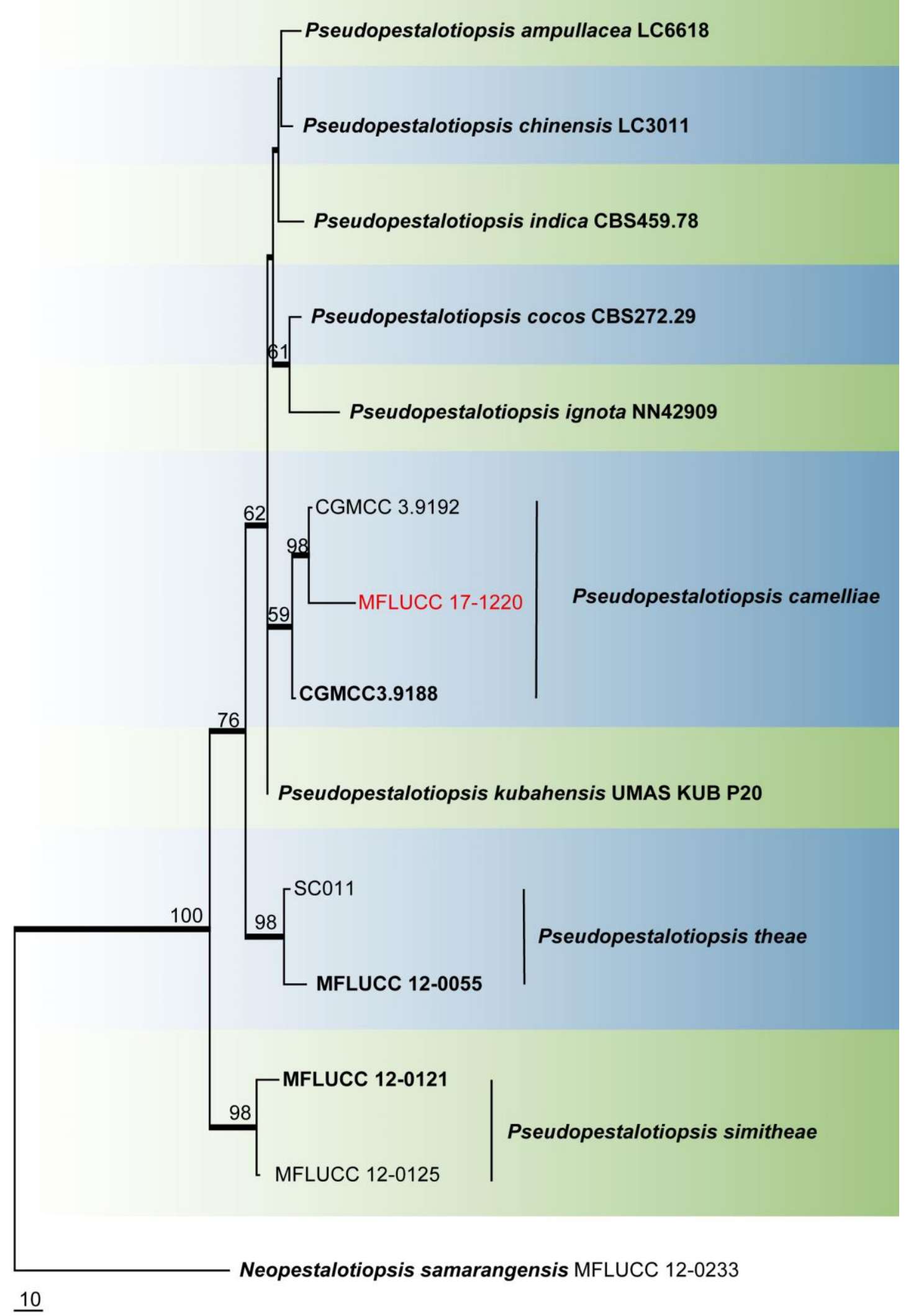

Fig. 47 - One of seven most parsimonious trees obtained from a heuristic search of combined ITS, TUB2 and TEF1 sequence data of taxa of Pseudopestalotiopsis. Parsimony bootstrap support values $\geq 50 \%$ are indicated at the nodes and branches with Bayesian posterior probabilities $\geq 0.90$ given in bold. Ex-type strains are in bold. Strains obtained in this study are in red. The tree is rooted with Neopestalotiopsis samarangensis MFLUCC 12-0233. 


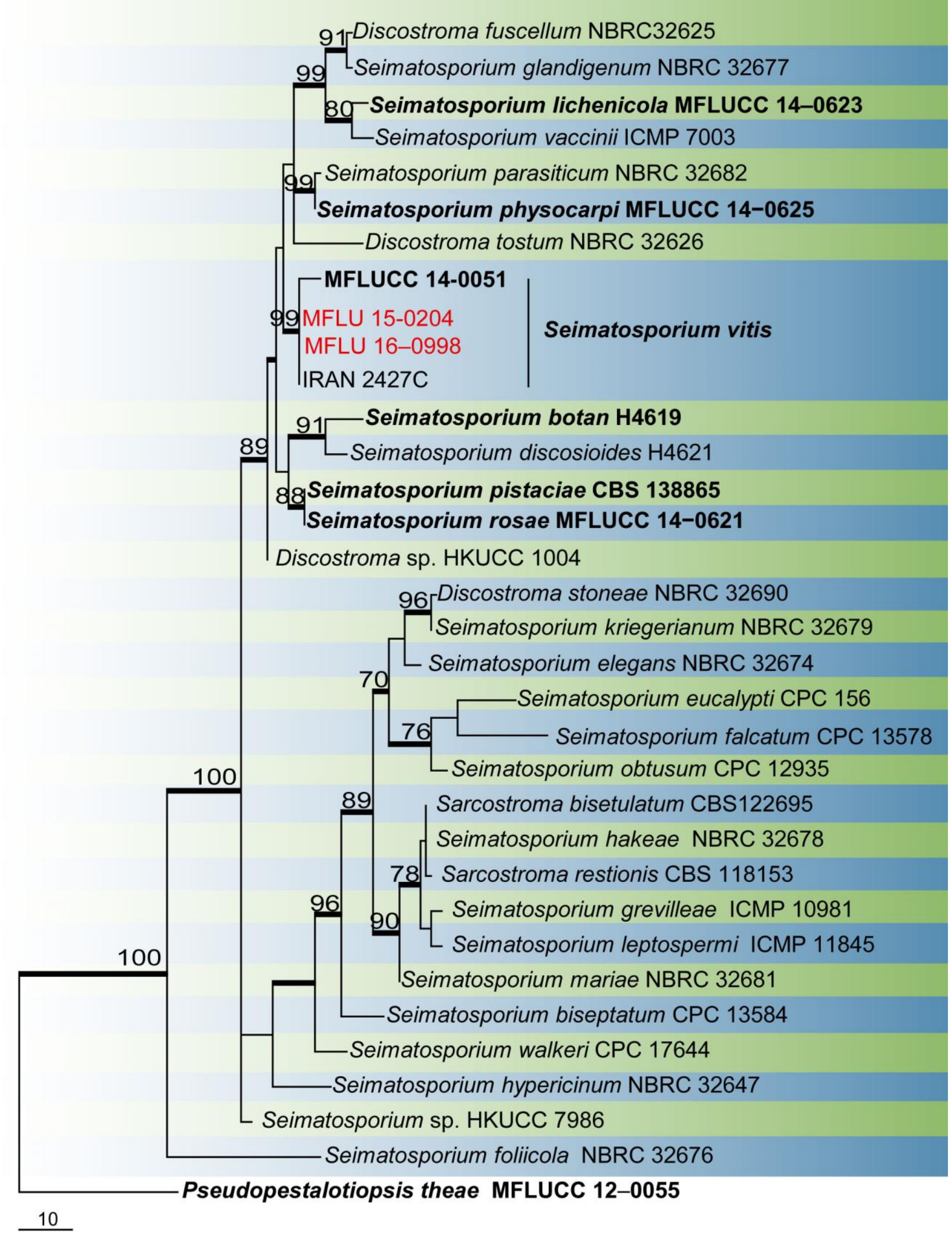

Fig. 48 - One of ten most parsimonious trees obtained from a heuristic search of combined ITS and LSU sequence data of taxa from the Seimatosporium. Parsimony bootstrap support values $\geq 50 \%$ are indicated at the nodes and branches with Bayesian posterior probabilities $\geq 0.75$ given in bold. Ex-type strains are in bold. Strains obtained in this study are in red. The tree is rooted with Pseudopestalotiopsis theae MFLUCC 12-0055. 


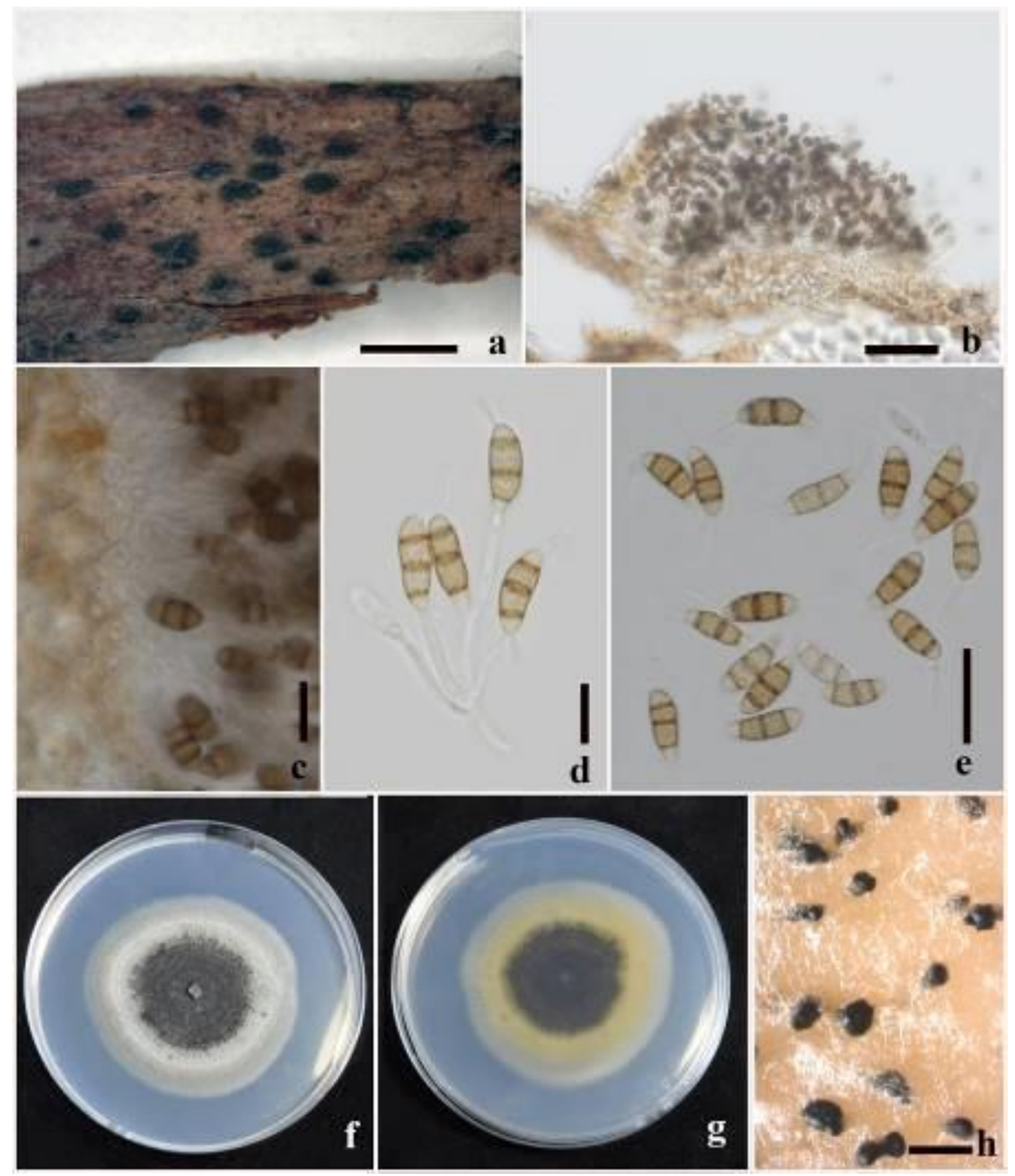

Fig. 49 - Seimatosporium vitis. a. Conidiomata on dead branch of Vitis vinifera b. Longitudinal section of a conidioma c. Longitudinal section of a conidioma wall d. Different stages of conidiogenesis e. Conidia $\mathrm{f}-\mathrm{g}$. Upper view (f). and the reverse view (g). of the colony on PDA $\mathrm{h}$. Conidiomata on PDA. Scale bars: $\mathrm{a}=1000 \mu \mathrm{m}, \mathrm{b}=50 \mu \mathrm{m}, \mathrm{c}, \mathrm{d}=10 \mu \mathrm{m}, \mathrm{e}=20 \mu \mathrm{m}, \mathrm{h}=2000 \mu \mathrm{m}$.

Sordariales Chadef. ex D. Hawksw. \& O.E. Erikss., Syst. Ascom. 5(1): 182 (1986)

Chaetomiaceae G. Winter, Rabenh. Krypt.-Fl., Edn 2 (Leipzig) 1.2: 153 (1885)

Chaetomiaceae was introduced by Winter (1885) and is typified by Chaetomium (Grunow et al. 1887). Twenty genera are presently placed in the family (Maharachchikumbura et al. 2015).

Chaetomium Kunze, in Kunze \& Schmidt, Mykologische Hefte (Leipzig) 1: 15 (1817)

Chaetomium is a cosmopolitan genus with more than 150 species. Special characteristics of Chaetomium are ascomata covered with hairs or setae, clavate or fusiform or sometimes cylindrical thin-walled asci, lack of paraphyses before ascomata mature and 1-celled, brown or grey-brown ascospores with germ pores (Hawksworth \& Wells 1973, von Arx et al. 1986). Strains in this study clustered together with the type strain of C. globosum (Fig. 50). 


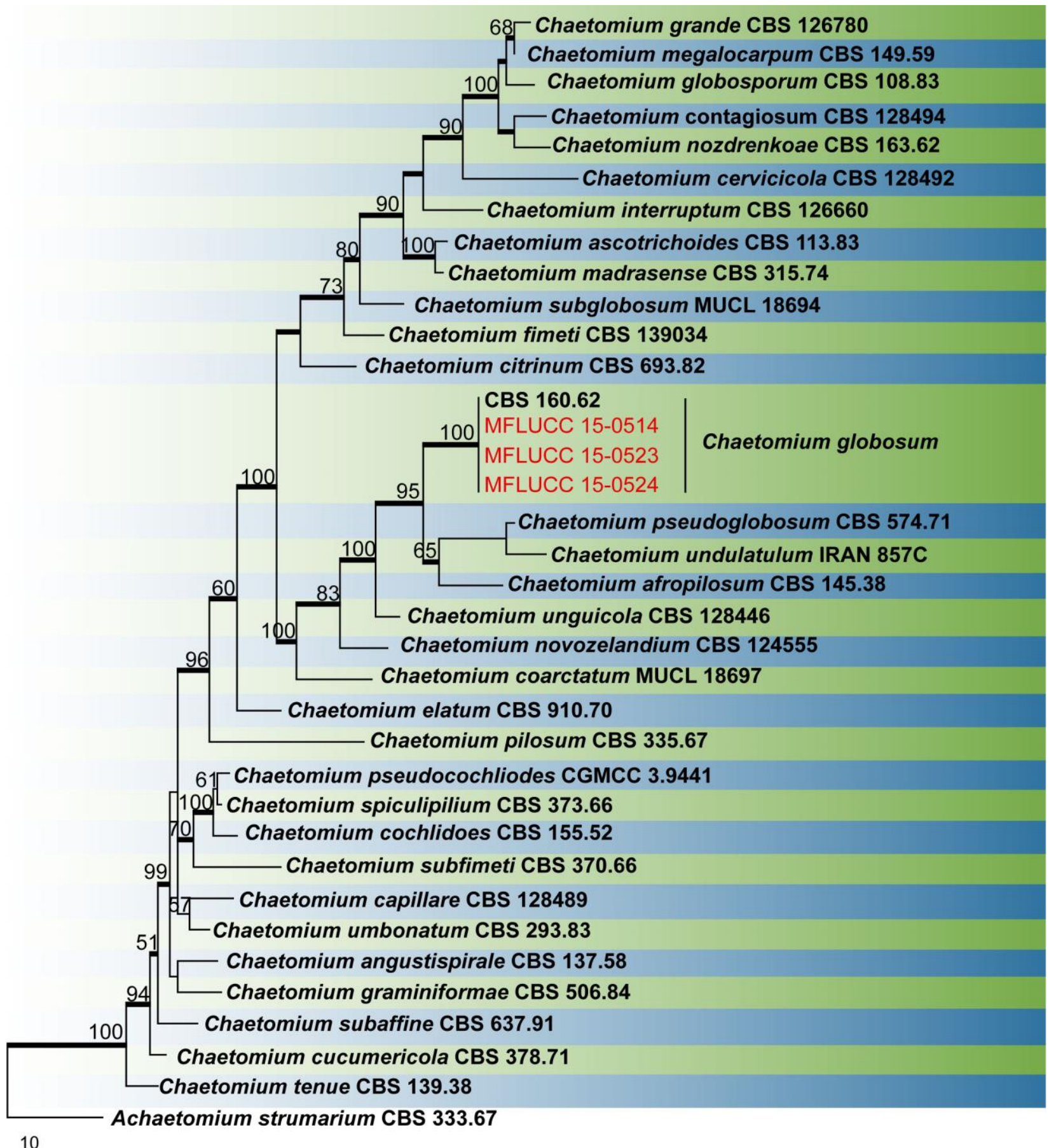

Fig. 50 - One of ten most parsimonious trees obtained from a heuristic search of combined ITS, LSU and TEF1 sequence data of taxa from the Chaetomium. Parsimony bootstrap support values above $50 \%$ are indicated at the nodes and branches with Bayesian posterior probabilities above 0.75 given in bold. Ex-type strains are in bold. Strains obtained in this study are in blue. The tree is rooted with Achaetomium strumarium CBS 333.67.

Chaetomium globosum Kunze, in Kunze \& Schmidt, Mykologische Hefte (Leipzig) 1: 16 (1817)

Facesoffungi number: FoF03614

Saprotrophic on dead and aerial branch of Vitis sp. Sexual morph: Ascomata superficial, ostiolate, greenish olivaceous or slightly dark olivaceous buff to grey in reflected light owing to ascomatal hairs, globose, ellipsoid, ovate or obovate, 160-300 $\times 130-220 \mu \mathrm{m}$. Ascomatal wall brown, composed of hypha-like or amorphous cells, textura intricata in surface view. Terminal hairs abundant, finely verrucose, brown, tapering and fading towards the tips, 3-5 $\mu \mathrm{m}$ diam. near the base, flexuous, undulate to loosely coiled with erect or flexuous lower part, usually unbranched. 
Lateral hairs brown, flexuous, fading and tapering towards the apices. Asci fasciculate, fusiform or clavate, spore-bearing part 28-40×10-15 $\mu \mathrm{m}$, stalks $18-25 \mu \mathrm{m}$ long, with eight biseriate ascospores, evanescent. Ascospores olivaceous brown when mature, limoniform, usually biapiculate, bilaterally flattened, $8-11 \times 6-7 \mu \mathrm{m}$, with an apical germ pore. Asexual morph: Not observed (see Maharachchikumbura et al. 2016 for description).

Culture characteristics - Colonies on PDA reaching $50 \mathrm{~mm}$ in 7 days at $25{ }^{\circ} \mathrm{C}$, brown or orange or white, woolly, border even, reverse buff-coloured to brown, aerial mycelium cottony or felty, with funiculose setae and hyphae. Mycelium abundant, intramatrical and aerial, composed of hyaline or dark brown, septate, hyphae.

Material examined - ITALY, Province of Forlì-Cesena, Marsignano - Predappio, on dead and aerial branch of Vitis sp., 29 December 2014, Erio Camporesi IT2321 (MFLU 15-0687); living culture, MFLUCC 15-0514, 16-0523, 16-0524.

Notes - Chaetomium globosum is known as a pathogen causing soft rot of beechwood (Levi et al. 1965). This species is also known for its biological control properties (Wang et al. 2012). This species has been reported from V. vinifera as an endophyte in Spain and Switzerland (Casieri et al. 2009; Gonzalez \& Tello 2011). This study provides the first report of C. globosum as a saprotroph associated with Vitis sp. in Italy.

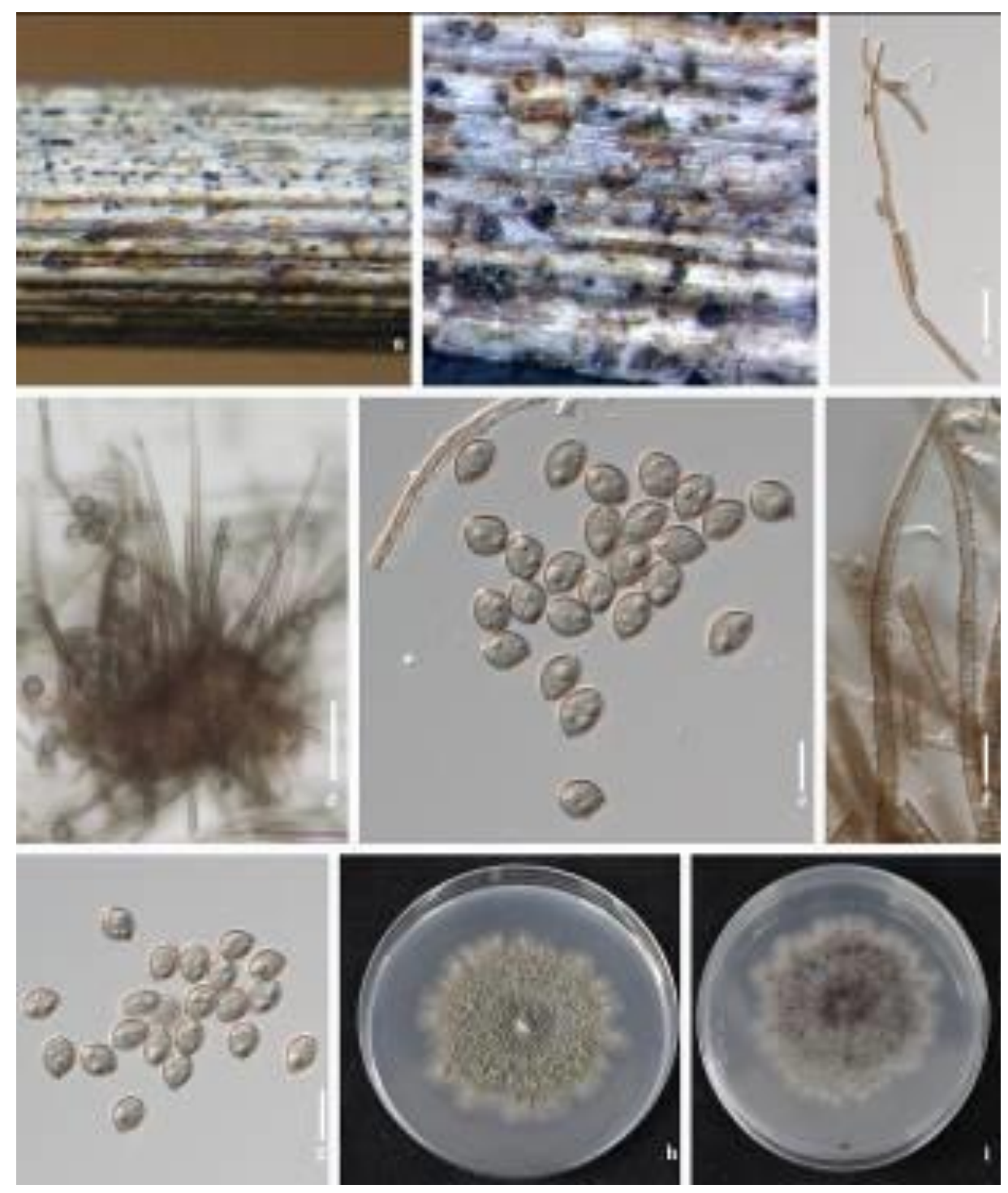

Fig. 51 - Chaetomium globosum. a, b. Conidiomata on host surface. c, f. Terminal ascomatal hairs. d. Ascoma. e, g. Conidia. h. Upper view of 7 day old culture. g. Reverse view of 7 day old culture. Scale bars: $\mathrm{d}=100 \mu \mathrm{m}, \mathrm{c}, \mathrm{e}-\mathrm{g}=10 \mu \mathrm{m}$. 
Chaetosphaeriales Huhndorf, A.N. Mill. \& F.A. Fernández, Mycologia 96(2): 378 (2004)

Chaetosphaeriaceae Réblová, M.E. Barr \& Samuels, Sydowia 51(1): 56 (1999)

The family is composed of morphologically diverse genera. Chaetosphaeriaceae is a family that needs molecular data to support the accepted genera (Maharachchikumbura et al. 2016).

Pseudolachnea Ranoj., Annls mycol. 8(3): 393 (1910)

Pseudolachnea is a genus with conidial appendages. There are only 21 epithets of this genus in Index Fungorum and a revision of this genus is needed (Index Fungorum 2018). Our strain from Vitis sp. clustered together with the type strain of $P$. hispidula (Fig. 52).

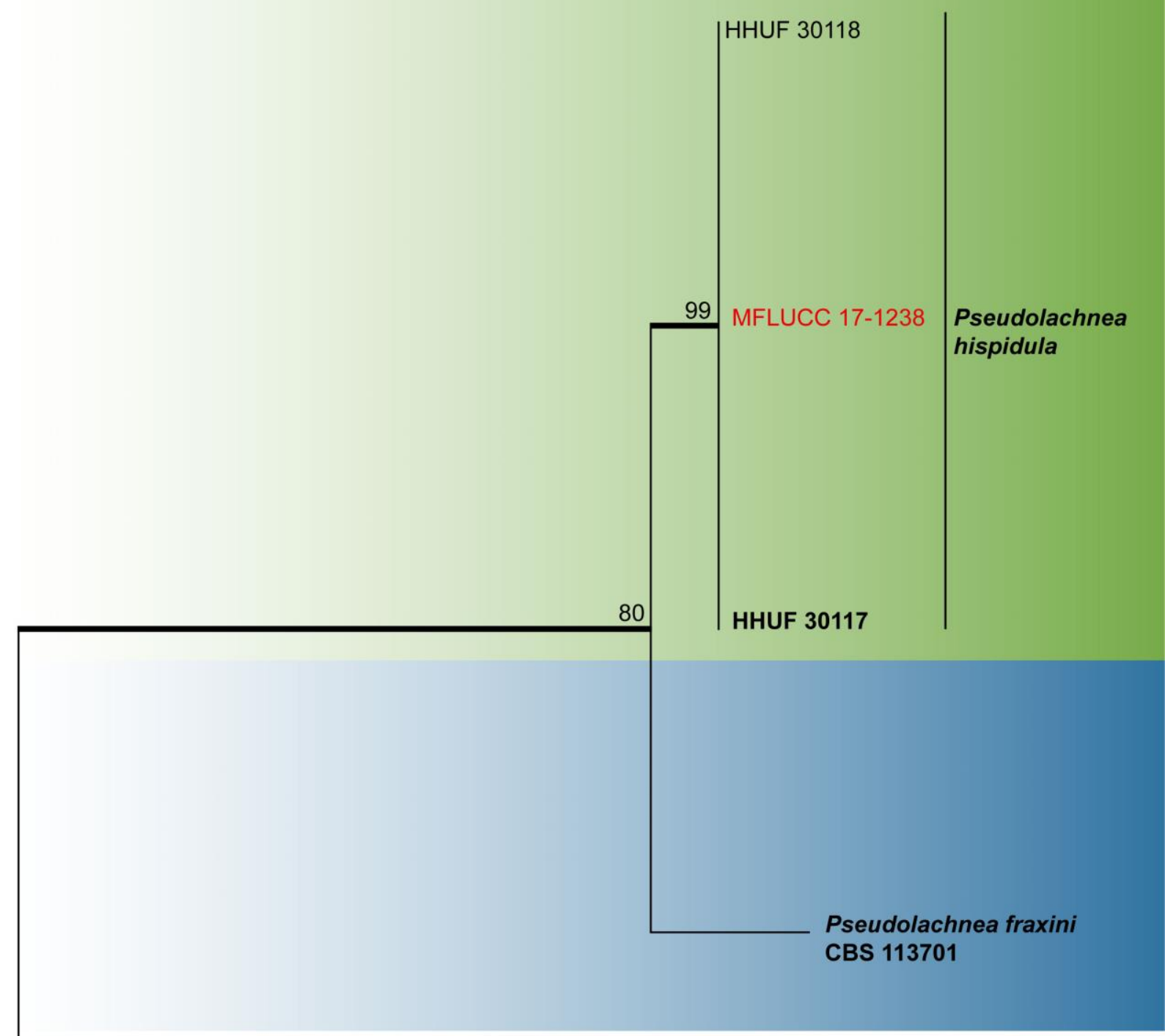

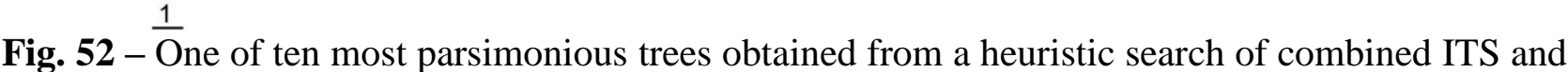
LSU sequence data of taxa from the Pseudolachnea. Parsimony bootstrap support values $\geq 50 \%$ are indicated at the nodes and branches with Bayesian posterior probabilities $\geq 0.90$ given in bold. Ex-type strains are in bold. Strains obtained in this study are in blue. The tree is rooted with Pseudolachnella yakushimensis HHUF 29996. 
Pseudolachnea hispidula (Schrad.) B. Sutton, Mycol. Pap. 141: 167 (1977)

Facesoffungi number: FoF03615

Saprotrophic on dead and aerial branches of Vitis vinifera. Sexual morph: Not observed. Asexual morph: Conidiomata stromatic, acervular, cupulate, setose, ellipsoid, 180-700 $\mu \mathrm{m}$ diam. Setae 100-200 $\mu \mathrm{m}$ long, acute and 2-3 $\mu \mathrm{m}$ wide at the apex, 4-8 $\mu \mathrm{m}$ wide at the base. Conidiophores up to $16 \mu \mathrm{m}$ long. Conidiogenous cells $8-10 \times 1-2 \mu \mathrm{m}(\bar{x}=9 \times 1 \mu \mathrm{m}, \mathrm{n}=20)$. Conidia 11-17×2-3 $\mu \mathrm{m}((\bar{x}=15 \times 2 \mu \mathrm{m}, \mathrm{n}=40), 1$-septate, fusiform, slightly curved, hyaline, bearing an unbranched appendage, $1-3 \mu \mathrm{m}$ long $(\bar{x}=2 \mu \mathrm{m}, \mathrm{n}=40)$, at each end.

Culture characteristics - Colonies on PDA attaining $40 \mathrm{~mm}$ diam. in 7 day at $25^{\circ} \mathrm{C}$ in the dark, floccose, straw coloured mycelium.

Material examined - ITALY, Province of Forlì-Cesena, Montegelli - Sogliano al Rubicone, on dead and aerial branch of Vitis vinifera, 31 March 2015, Erio Camporesi IT 2429 (MFLU 17-1250); living culture, MFLUCC 17-1238.

Notes - Our strain is morphologically similar to the type strain P. hispidula and the combined phylogenetic analysis of ITS and LSU sequence data established this. There are no records of species of this genus associated with Vitis $\mathrm{sp}$. This study provides the first record of a Pseudolachnea species associated with Vitis vinifera.

Diaporthales Nannf., Nova Acta R. Soc. Scient. upsal., Ser. 4 8(no. 2): 53 (1932)

Diaporthaceae Höhn. ex Wehm., Am. J. Bot. 13: 638 (1926)

This family contains pathogens, endophytes and saprotrophs and has a worldwide distribution (Maharachchimbura et al. 2016). In this study we provide accounts of D. ampelina, D. eres and D. rudis from Vitis sp. and a new species is introduced based on morphological traits and phylogeny (Fig. 54).

Diaporthe Nitschke, Pyrenomyc. Germ. 2: 240 (1870)

Species of this genus are plant pathogens, endophytes or saprotrophs, commonly isolated from a wide range of hosts (Udayanga et al. 2012, 2014, Hyde et al. 2014). The phylogeny and taxonomy of the genus has been addressed in recent studies (Udayanga et al. 2012, 2014, 2015).

Diaporthe ampelina (Berk. \& M.A. Curtis) R.R. Gomes, Glienke \& Crous, Persoonia 31: 14 (2013)

Facesoffungi number: FoF03516

Saprotrophic on dead and aerial branch of Vitis vinifera. Sexual morph: Not observed. Asexual morph: Conidiomata up to 350 $\mu \mathrm{m}$ diam, 200-300 $\mu \mathrm{m}$ high, pycnidial, globose, unilocular, black, erumpent, walls consisting of two regions of textura angularis; the outer region brown, 2-3 cells thick, inner region brown 3-4 cells thick, with the outside cells compressed. Alpha conidiophores $8-30 \times 1-3 \mu \mathrm{m}(\bar{x}=24 \times 2 \mu \mathrm{m}, \mathrm{n}=10)$, hyaline, smooth, densely aggregated, cylindrical, straight to sinuous. Alpha conidiogenous cells $4-15 \times 1-2 \mu \mathrm{m}(\bar{x}=11 \times 2 \mu \mathrm{m}, \mathrm{n}=20)$, phialidic, subcylindrical, terminal and lateral, slightly tapering towards apex. Paraphyses not observed. Alpha conidia $7-12 \times 1-4 \mu \mathrm{m}(\bar{x}=8 \times 3 \mu \mathrm{m}, \mathrm{n}=40)$, commonly found, aseptate, hyaline, smooth, guttulate, fusoid to ellipsoid, apex acutely rounded, base obtuse to subtruncate. Beta conidia $18-25 \times 1-2 \mu \mathrm{m}(\bar{x}=21 \times 1 \mu \mathrm{m}, \mathrm{n}=20)$, straight, curved. Gamma conidia $13-16 \times 1-2 \mu \mathrm{m}$ $(\bar{x}=15 \times 1 \mu \mathrm{m}, \mathrm{n}=20)$.

Culture characteristics - Colonies on PDA attain $40 \mathrm{~mm}$ in 7 day, with fluffy white aerial mycelium with patches of saffron, reverse luteous to olivaceous-grey.

Material examined - ITALY, Province of Forlì-Cesena, Fiumana - Predappio, on dead and aerial branch of Vitis vinifera, 13 February 2016, Erio Camporesi IT 2831 (MFLU 16-0879); living culture, MFLUCC 17-1270, 17-1271; ITALY, Province of Forlì-Cesena [FC], Teodorano Meldola, on dead branch of Vitis vinifera, 21 February 2015, Erio Camporesi IT 2384 (MFLU 153508); living culture MFLUCC 16-0960. 
Notes - Diaporthe ampelina is known to causes cane and leaf spot and infection of pruning wounds of Vitis sp. (Dissanayake et al. 2017). Our strains show similar morphology to the type species of $D$. ampelina and clustered together with the type.
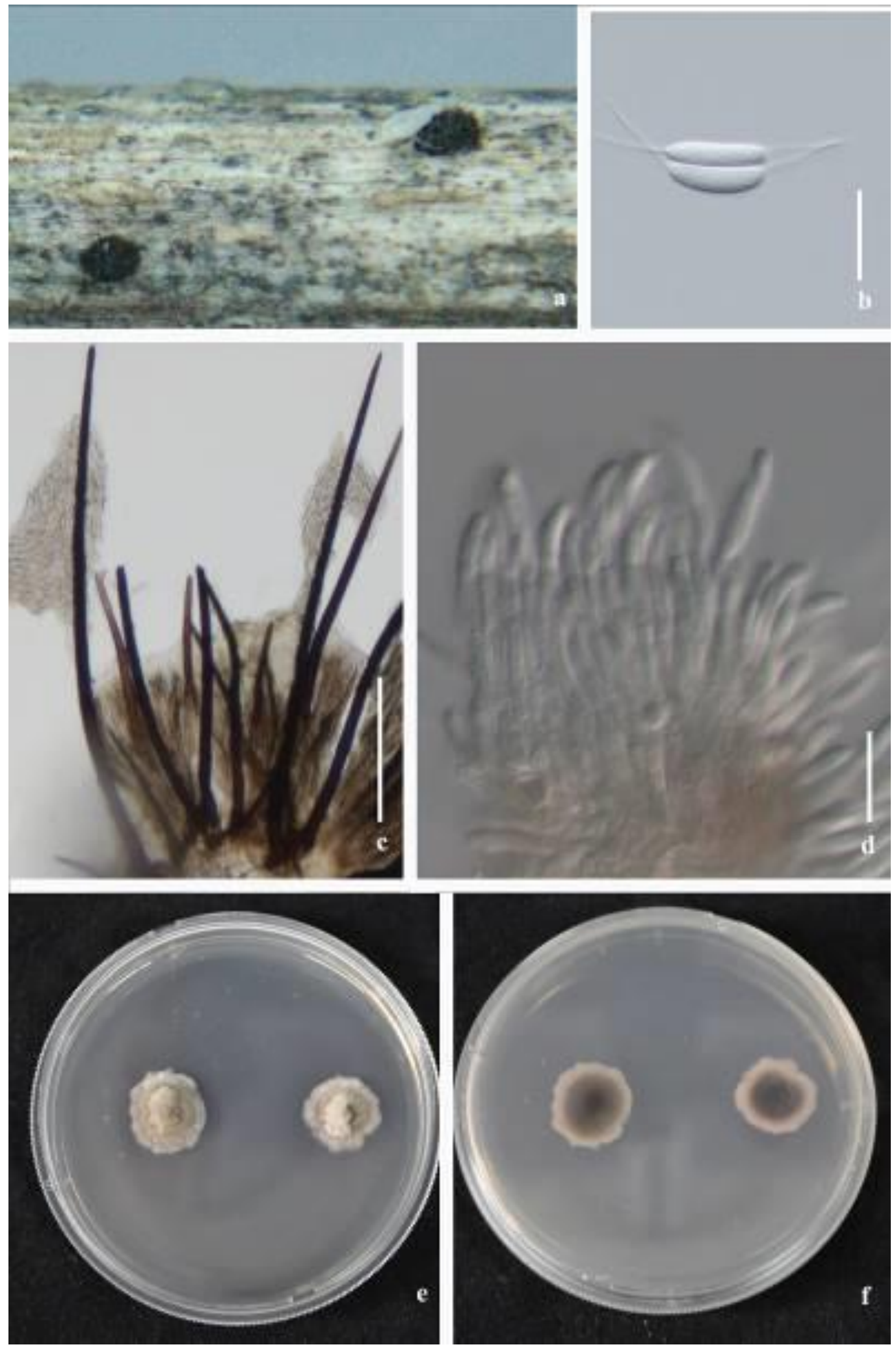

Fig. 53 - Pseudolachnea hispidula. a. Conidiomata on host. b. Conidia. c. Setae. d. Conidiophores and conidiogenous cells. e. Upper view of 7 day old culture. f. Reverse view of 7 day old culture. Scale bars: $\mathrm{c}=50 \mu \mathrm{m}, \mathrm{b}, \mathrm{d}=10 \mu \mathrm{m}$. 


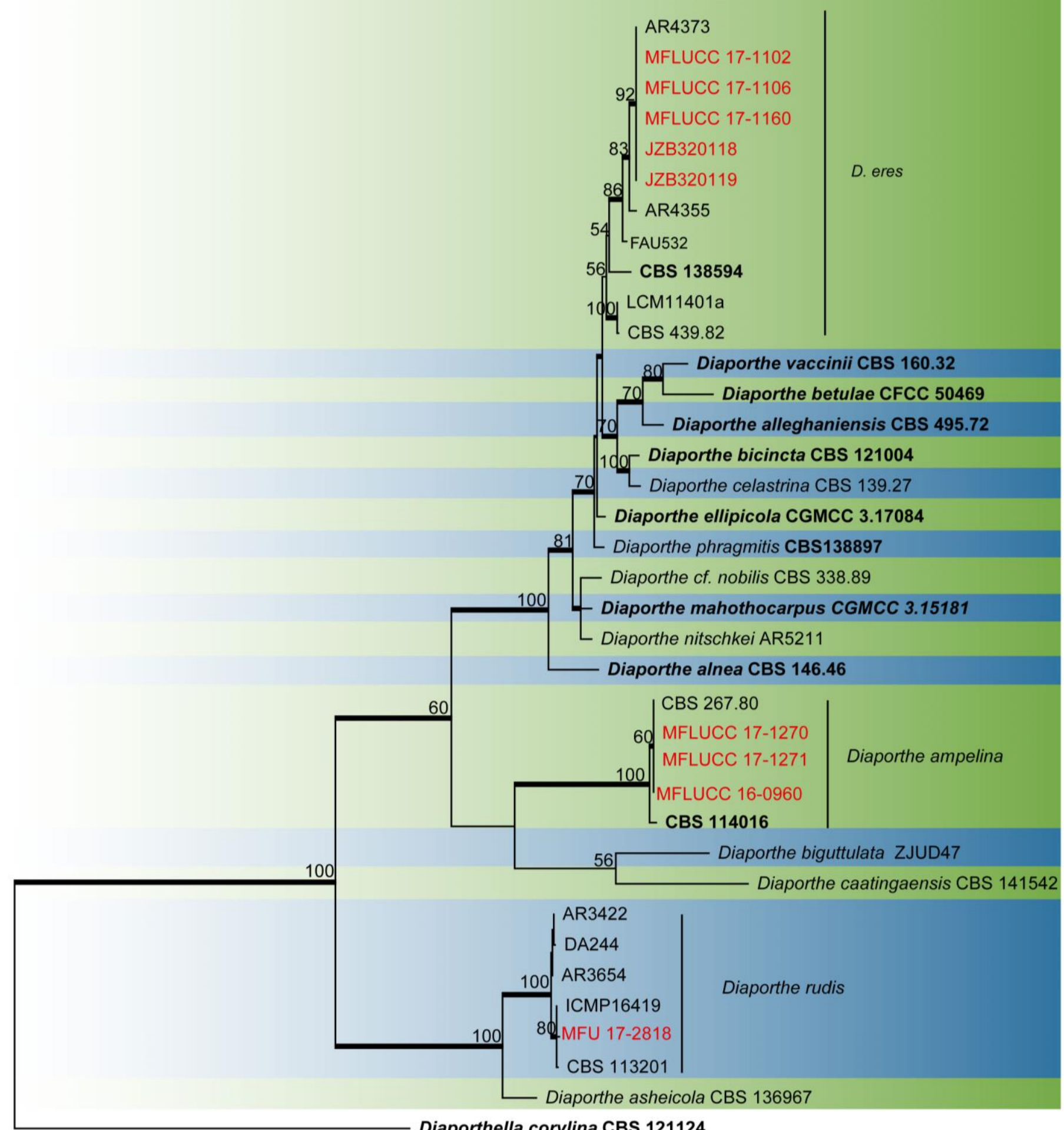

$\underline{10}$

Fig. 54 - One of ten most parsimonious trees obtained from a heuristic search of combined ITS, TUB2, TEF1 and CAL sequence data of taxa from Diaporthe. Parsimony bootstrap support values above $50 \%$ are indicated at the nodes and branches with Bayesian posterior probabilities above 0.75 are given in bold. Ex-type strains are in bold. Strains obtained in this study are in red. The tree is rooted with Diaporthe foeniculiana CBS 111553. 

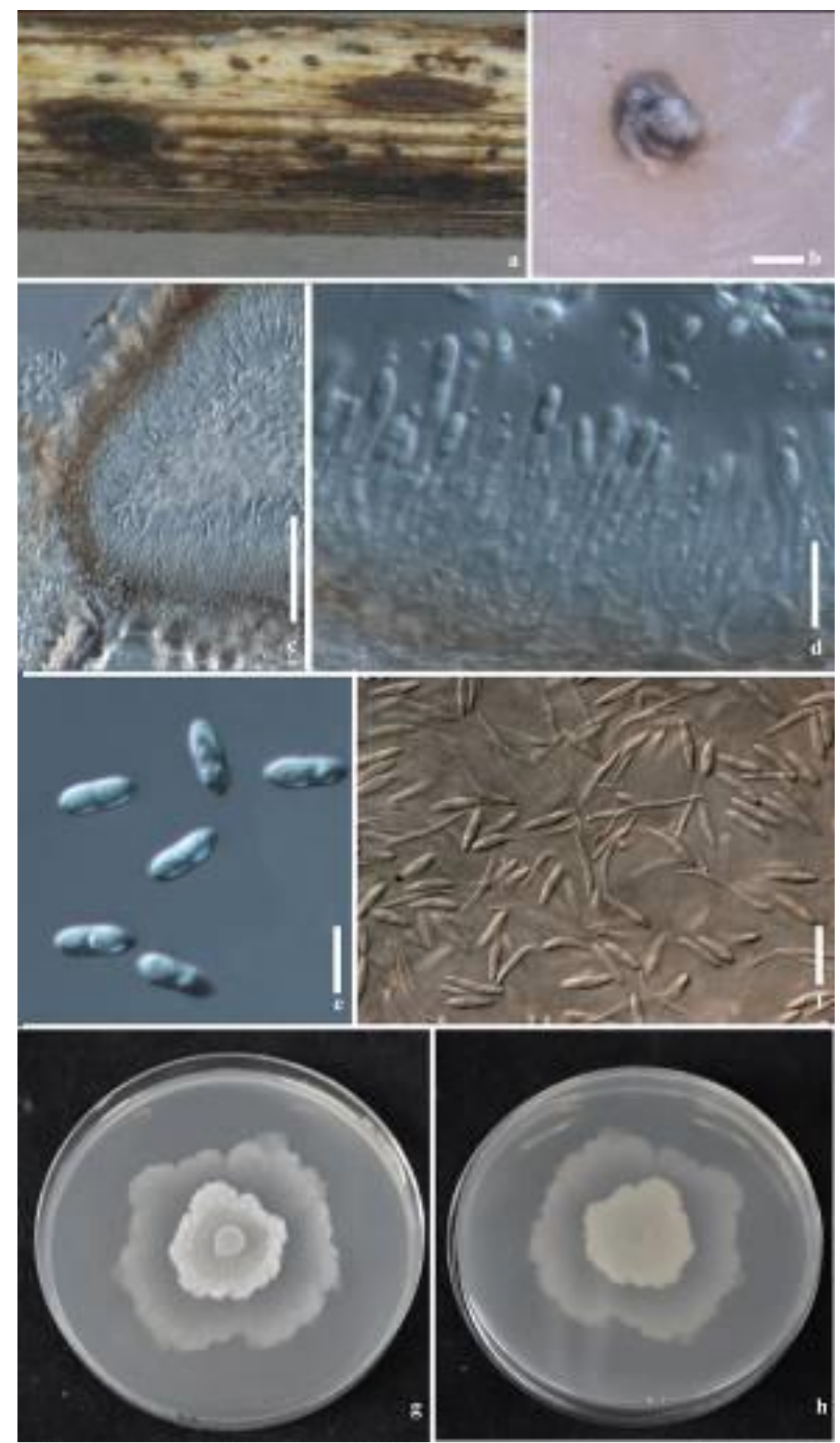

Fig. 55 - Diaporthe ampelina. a. Conidiomata on host tissue. b. Conidioma on PDA. c. Section of conidioma. d. Conidiophores. e. Alpha conidia. f. Beta and gamma conidia. g. Upper view of 7 day old culture. $h$. Reverse view of 7 day old culture. Scale Bars: $c=50 \mu \mathrm{m}, \mathrm{d}=20 \mu \mathrm{m}$ b, e, $\mathrm{f}=10 \mu \mathrm{m}$.

Diaporthe eres Nitschke, Pyrenomyc. Germ. 2: 245 (1870)

Facesoffungi number: FoF02182

Saprotrophic on dead shoots of Vitis vinifera. Sexual morph: Not observed. Asexual morph: Pycnidia 200-250 $\mu \mathrm{m}$ diam, globose, black, elongated neck, often with yellowish conidial cirrus extruding from ostiole, walls parenchymatous, consisting of 3-4 layers of medium brown cells of textura angularis. Conidiophores $10-15 \times 2-3 \mu \mathrm{m}(\bar{x}=12 \times 2, \mathrm{n}=10)$, hyaline, smooth, unbranched, ampulliform. Conidiogenous cells $0.5-1 \mu \mathrm{m}$ diam, phialidic, cylindrical, terminal, slightly tapering towards the apex. Paraphyses absent. Alpha conidia $7-9 \times 3-4 \mu \mathrm{m}$ $(\bar{x}=8 \times 3, n=40)$, abundant, aseptate, hyaline, smooth, ovate to ellipsoidal, often biguttulate, base 
sub-truncate. Beta conidia 22-29×1-2 $\mu \mathrm{m}(\bar{x}=25 \times 1, \mathrm{n}=30)$, aseptate, hyaline, smooth, fusiform to hooked, base sub-truncate.

Cultural characteristics - Colonies on PDA reaching $70 \mathrm{~mm}$ in 14 days, white, aerial, fluffy mycelium, reverse iron-grey to black.

Material examined - CHINA, Beijing, on dead shoots of Vitis vinifera, 3 June 2015, Ruvishika Jayawardena, culture MFLUCC 17-1102, 17-1106 and 17-1160.

Notes - Diaporthe eres is a common pathogen of grapevine causing cankers (Fischer et al. 2016). This species is also a saprotroph (Udayanga et al. 2015). Our isolates clustered with the type of $D$. eres with high bootstrap support.
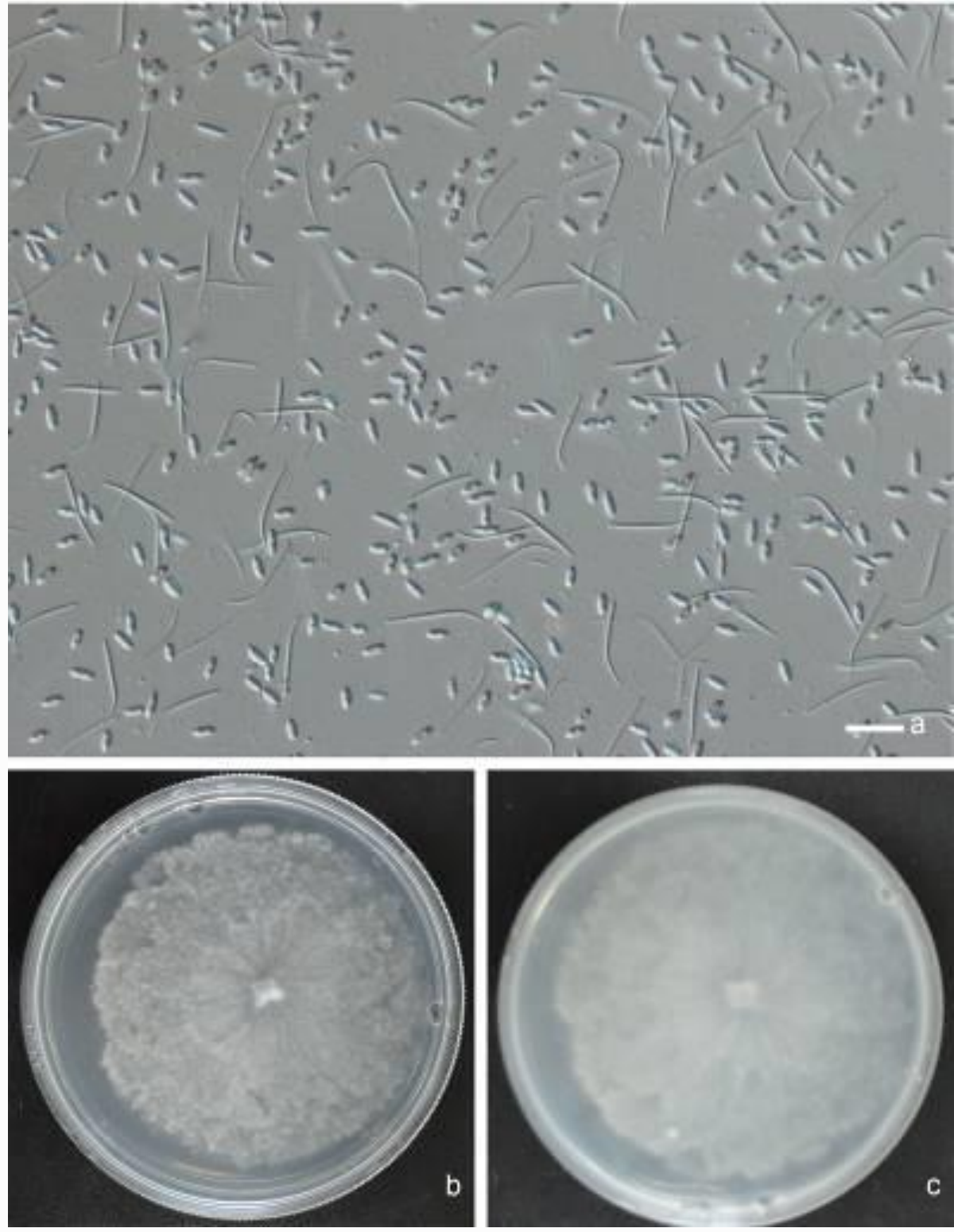

Fig. 56 - Diaporthe eres. a. Alpha and beta conidia. b. Upper view of 7 day old culture. c. Reverse view of 7 day old culture. Scale Bars: $a=10 \mu \mathrm{m}$.

Diaporthe rudis (Fr.) Nitschke, Pyrenomyc. Germ. 2: 282 (1870)

Facesoffungi number: FoF03821

Saprotrophic on dead branch of Vitis vinifera. Sexual morph: Ascomata 300-340 $\mu \mathrm{m}$ high, 125-270 $\mu \mathrm{m}$ diam., $(\bar{x}=330 \times 250 \mu \mathrm{m}, \mathrm{n}=10)$, solitary or rarely aggregated, scattered, immersed to erumpent, globose to subglobose, black, coriaceous, ostiolate, papillate. Papilla 150-170 $\mu \mathrm{m}$ high, 65-70 $\mu \mathrm{m}$ wide $(\bar{x}=160 \times 75 \mu \mathrm{m}, \mathrm{n}=10)$, asymmetrical, short, internally covered by periphyses. Peridium inner, hyaline, thick-walled, compressed cells of textura angularis and outer, brown, 
thick-walled, compressed cells of textura angularis. Hamathecium aparaphysate. Asci $55-60 \times 10-$ $13 \mu \mathrm{m}(\bar{x}=57 \times 13 \mu \mathrm{m}, \mathrm{n}=20), 8$-spored, unitunicate, ellipsoid to fusiform, sessile, apex with characteristic J-, apical ring. Ascospores $9-13 \times 3-4 \mu \mathrm{m}(\bar{x}=13 \times 3 \mu \mathrm{m}, \mathrm{n}=20)$, biseriate, ellipsoid to fusiform, 1-septate, slightly constricted at the septa, ends pointed, sometimes upper cell narrowed towards the ends. Asexual morph: Not observed.

Material examined - ITALY, Province of Forlì-Cesena, Marsignano, Predappio, on dead and aerial branch of Vitis vinifera, 7 February 2014, Erio Camporesi, IT 1709, (MFLU 14-0xxxx).

Notes - A culture is not available for this species, direct sequencing of fruiting bodies was conducted. Diaporthe rudis is known as a pathogen on Vitis vinifera from several countries. This study provides the sexual morph of this species and reports this species as a saprotroph on $V$. vinifera in Italy.

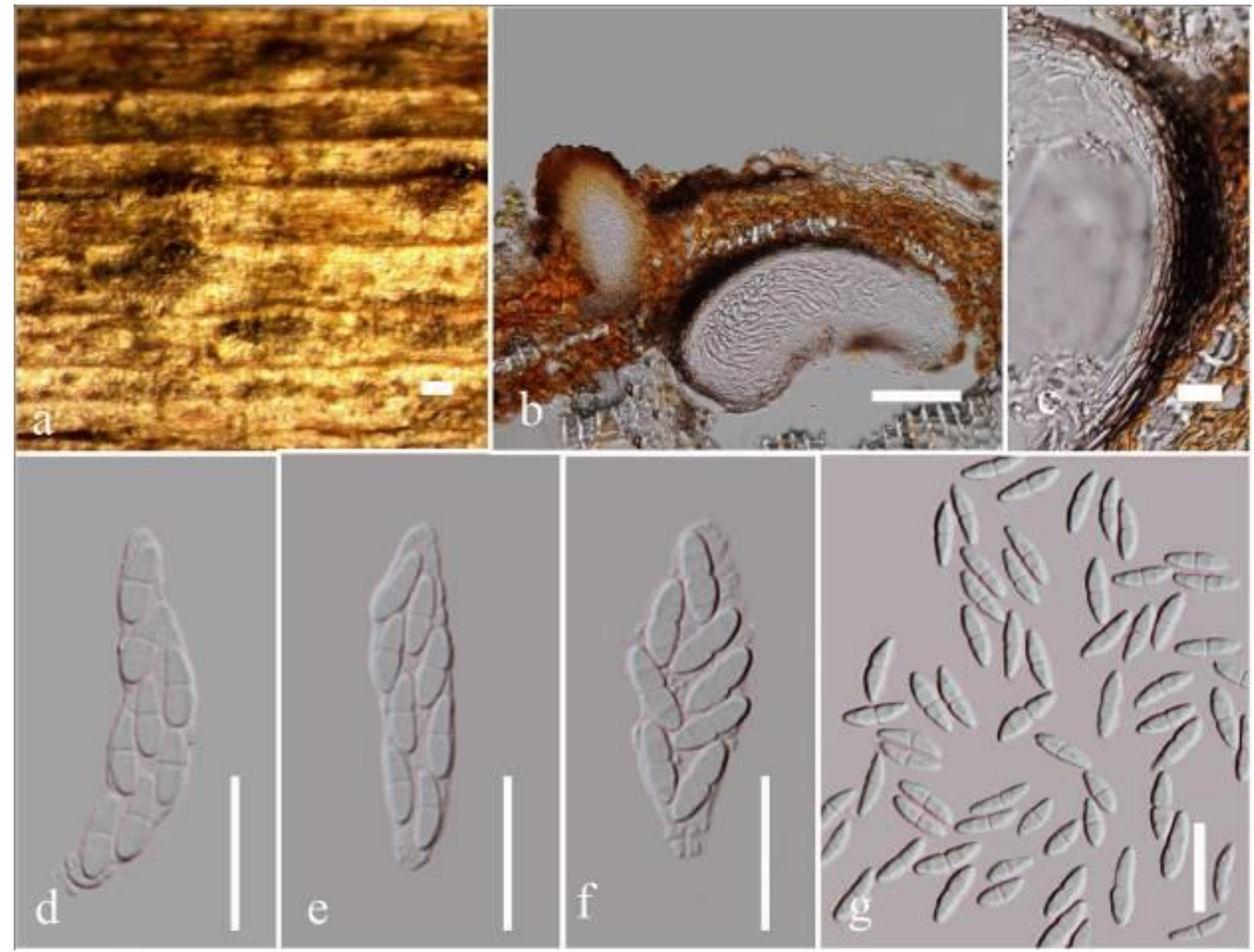

Fig. 57-Diaporthe rudis. a. Ascomata on substrate. b. Cross section of ascoma. c. Peridium. d-f. Asci. g. Ascospores. Scale bars: $\mathrm{a}=200 \mu \mathrm{m}, \mathrm{b}=100 \mu \mathrm{m}, \mathrm{c}=20 \mu \mathrm{m}, \mathrm{d}-\mathrm{g}=10 \mu \mathrm{m}$.

Schizoparmaceae Rossman, D.F. Farr \& Castl. [as 'Schizoparmeaceae'], Mycoscience 48(3): 137 (2007)

This family was introduced to accommodate Schizoparme and the asexual morph genus Coniella (Maharachchikumbura et al. 2016). Species of this family are pathogens or saprotrophs.

Coniella Höhn., Ber. dt. bot. Ges. 36(7): 316 (1918)

Coniella was introduced to accommodate C. pulchella Höhn. Species of Coniella are commonly associated with a wide variety of woody and herbaceous hosts (van Niekerk et al. 2004). Our strains clustered together with the type species of C. vitis (Fig. 59). 
Coniella vitis Chethana, Yan, Li \& K.D. Hyde, Chethana et al. Plant Diversity 101(12):2129(2017) Facesoffungi number: FoF02722

See Chethana et al. (2017) for description.
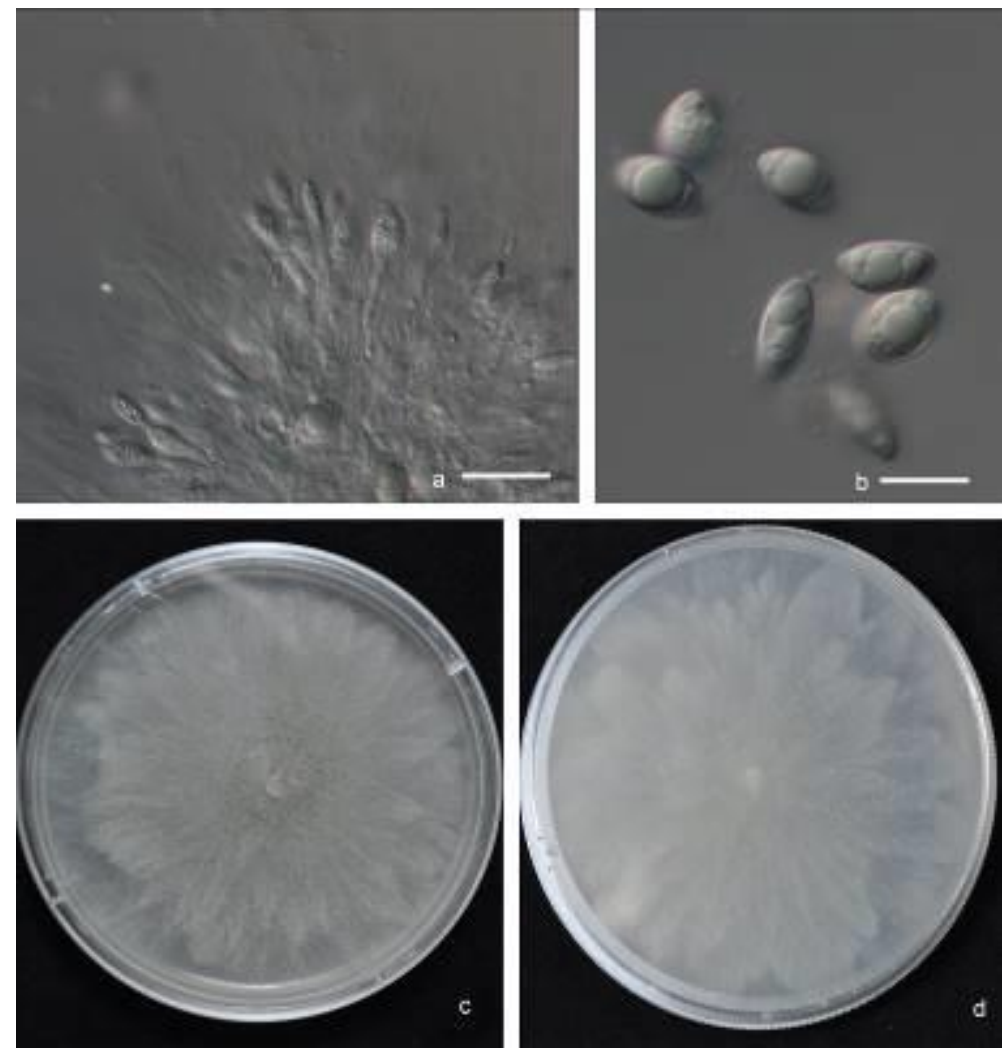

Fig. 58 - Coniella vitis. a. Conidiogenous cells. b. Conidia c. Upper view of 7 day old culture. d. Reverse view of 7 day old culture. Scale Bars: $a-b=10 \mu \mathrm{m}$.

Material examined - CHINA, Beijing, on dead leaves of Vitis vinifera cv. Red Globe, 3 June 2015, Ruvishika Jayawardena, culture, MFLUCC 17-1113, JZB370026; CHINA, Beijing, on dead bark of $V$. vinifera cv. Red Globe, 3 June 2015, Ruvishika Jayawardena, culture, MFLUCC 17-1123, MFLUCC 17-1138;. CHINA, Beijing, on dead shoot of V. vinifera cv. Red Globe, 3 June 2015, Ruvishika Jayawardena, culture, MFLUCC 17-1125, JZB370014, JZB370009.

Notes - Coniella vitis was introduced by Chethana et al. (2017) to accommodate the white rot pathogen in Chinese vineyards. Our strains clustered with the type strain of this species. This study provides the first record of $C$. vitis as a saprotroph on $V$. vinifera in China.

Glomerellales Chadef. ex Réblová, W. Gams \& Seifert, Stud. Mycol. 68: 170 (2011)

Glomerellaceae Locq. ex Seifert \& W. Gams, in Zhang, Castlebury, Miller, Huhndorf, Schoch, Seifert, Rossman, Rogers, Kohlmeyer, Volkmann-Kohlmeyer \& Sung, Mycologia 98(6): 1083 (2007) [2006]

Glomerellaceae is a monotypic family, mainly comprised of pathogens. The family was invalidly published by Locquin (1984) and was validated in Zhang et al. (2006). This family was accepted as one of the three families of Glomerellales in Réblová et al. (2011). This family is characterized by the Colletotrichum asexual morph and the Glomerella sexual morph, the latter was synonymized under Colletotrichum (Hyde et al. 2014, Maharachchikumbura et al. 2016a).

Colletotrichum Corda, in Sturm, Deutschl. Fl., 3 Abt. (Pilze Deutschl.) 3(12): 41 (1831)

This genus was introduced by Corda (1831) for $C$. lineola Corda and until recent studies used a polyphasic approach including multigene phylogenetic analysis, the genus was highly confused (Cai et al. 2009, Hyde et al. 2009a,b). Colletotrichum is comprised mainly of pathogens, 
but some species are endophytes or saprotrophs (Hyde et al. 2014, Jayawardena et al. 2016b). Kirk et al. (2001, 2008), Réblová et al. (2011) placed Colletotrichum in Glomerellaceae and this placement was confirmed by Maharachchikumbura et al. (2016a). We provide accounts for $C$. dematium, $C$. godetiae, $C$. hebeiense, $C$. siamense, $C$. truncatum and $C$. viniferum based on morphology and multigene phylogenetic analysis.

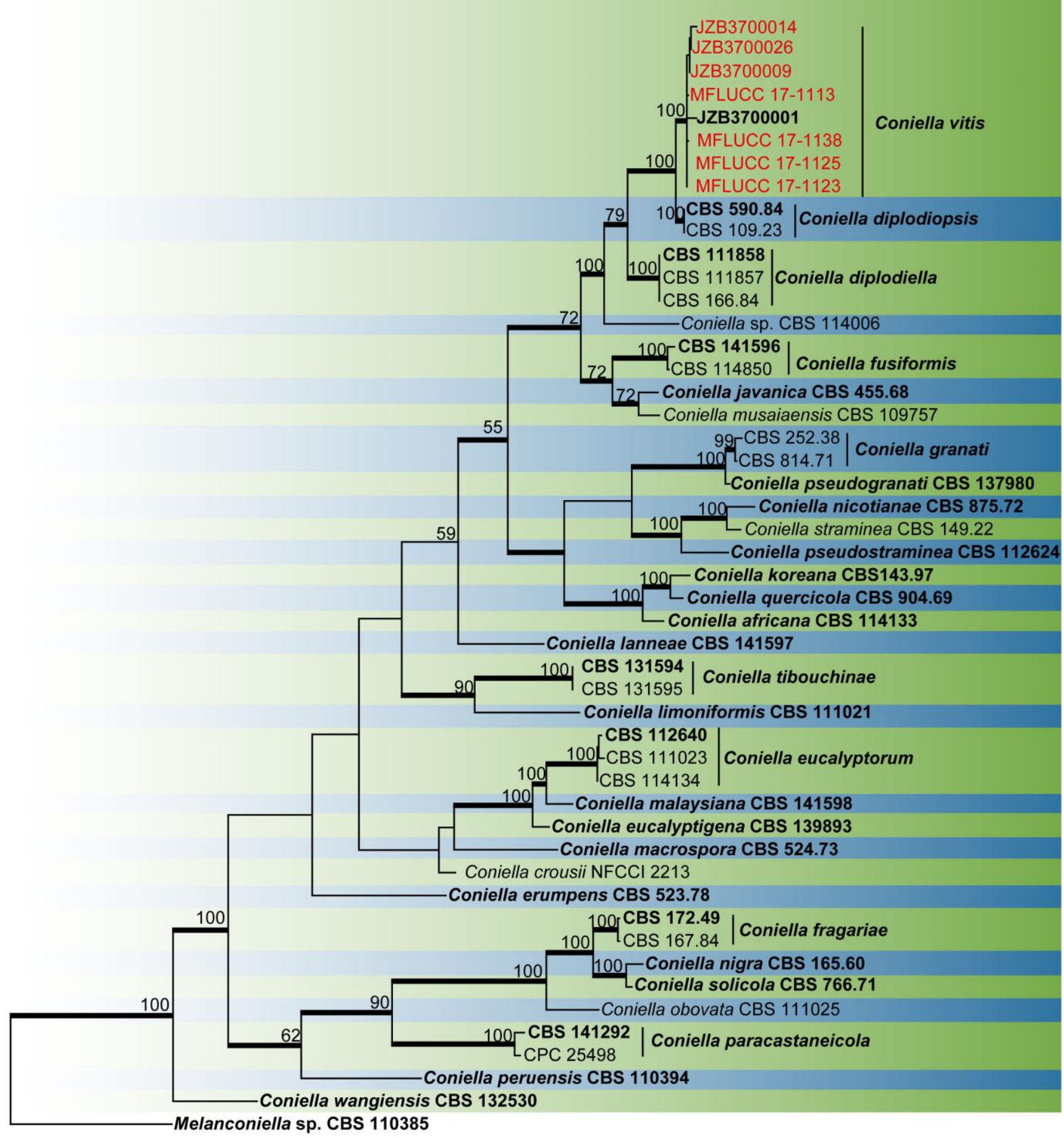

Fig. 59 - One of seven most parsimonious trees obtained from a heuristic search of combined ITS, LSU, histone and TEF1 sequence data of taxa of Coniella. Parsimony bootstrap support values $\geq 50$ $\%$ are indicated at the nodes and branches with Bayesian posterior probabilities $\geq 0.90$ are given in bold. Ex-type strains are in bold. Strains obtained in this study are in red. The tree is rooted with Melanconiella sp. CBS 110385. 


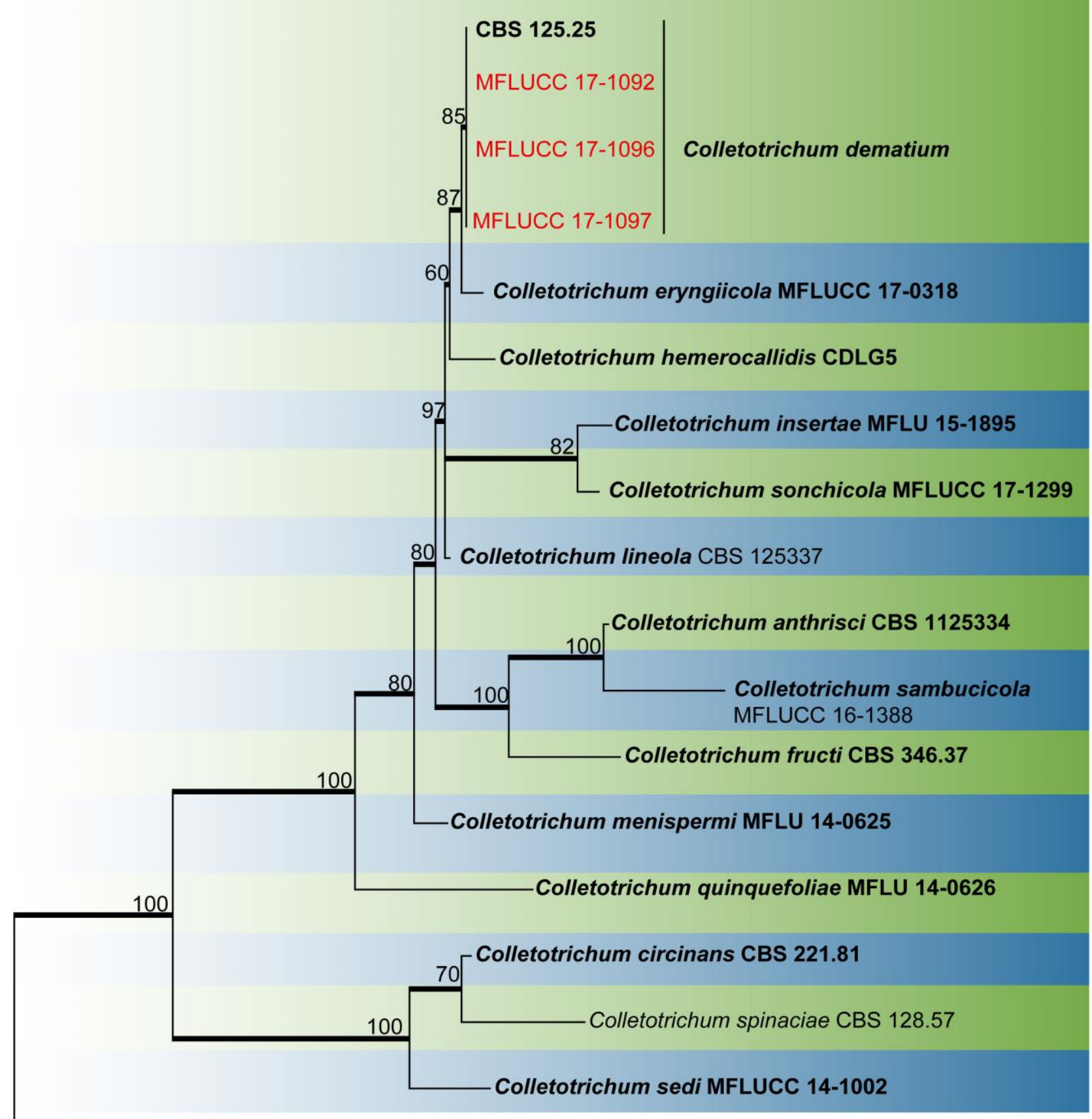

Colletotrichum nigrum CBS 169.49

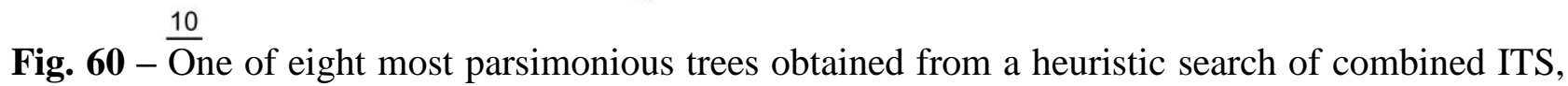
GAPDH, CHS, ACT and TUB2 sequence data of taxa for the dematium species complex. Parsimony bootstrap support values $\geq 50 \%$ are indicated at the nodes and branches with Bayesian posterior probabilities $\geq 0.90$ given in bold. Ex-type strains are in bold. Strains obtained in this study are in blue. The tree is rooted with Colletotrichum nigrum CBS 169.49.

Colletotrichum dematium (Pers.) Grove, J. Bot., Lond. 56: 341 (1918)

Facesoffungi number: FoF03598

Saprotrophic on dead and dying twigs of Vitis vinifera. Sexual morph: Not observed. Asexual morph: Conidiomata $130-400 \mu \mathrm{m}(\bar{x}=270 \mu \mathrm{m}, \mathrm{n}=10)$ diam., black, acervulus, oval, solitary, gregarious. Setae straight or \pm bent, rarely observed, dark brown, becoming paler towards the apex, opaque, smooth-walled, 1-6-septate, 30-145 $\mu \mathrm{m}$ long, base cylindrical, slightly inflated, 
7-11 $\mu \mathrm{m}$ diam., tip acute to rounded, smooth. Conidiophores simple, to $20 \mu \mathrm{m}$ long, hyaline to pale brown, septate. Conidiogenous cells enteroblastic, 5-16 $\times 2-4 \mu \mathrm{m}(\bar{x}=12 \times 3 \mu \mathrm{m}, \mathrm{n}=20)$, hyaline, smooth-walled, cyllindrical to slighty inflated, opening $0.5-1 \mu \mathrm{m}$ wide, collarette or periclinal thickening observed. Conidia $17-25 \times 3-5 \mu \mathrm{m}(\bar{x}=18 \times 4 \mu \mathrm{m}, \mathrm{n}=15)$, L/W ratio=5, hyaline, smooth or verruculose, aseptate, curved, both sides gradually tapering towards the round to slightly acute apex and truncate base, guttulate. Appressoria not observed.

Cultural characteristics - Colonies on PDA, reaching 40-55 mm in 7 days at $25{ }^{\circ} \mathrm{C}$, flat with entire margin, aerial mycelium sparse, short, pale olivaceous-grey, colony surface buff, some sectors dark grey-olivaceous to dark olivaceous-grey, iron-grey acervuli can be observed mainly on the edge of the colony. Reverse olivaceous-green, concentric rings clearly observed.

Material examined - RUSSIA, Rostov region, Shakhty city, urban green area, on dead and dying twigs of Vitis vinifera, 1 March 2016, Timur S. Bulgakov T-1209 (MFLU 16-1308), culture, MFLUCC 16-1388=KUMCC 16-0127, MFLUCC 17-1092, MFLUCC 17-1096, MFLUCC 171097.

Notes - Colletotrichum dematium species complex is mainly characterized by having curved conidia (Jayawardena et al. 2016b). The strains used in this study cluster together with the type species of $C$. dematium (Fig. 58). Colletotrichum dematium has been reported as an endophyte in Vitis sp. (Jayawardena et al. 2016b). This study provides the first report of C. dematium as a saprotroph on Vitis sp.
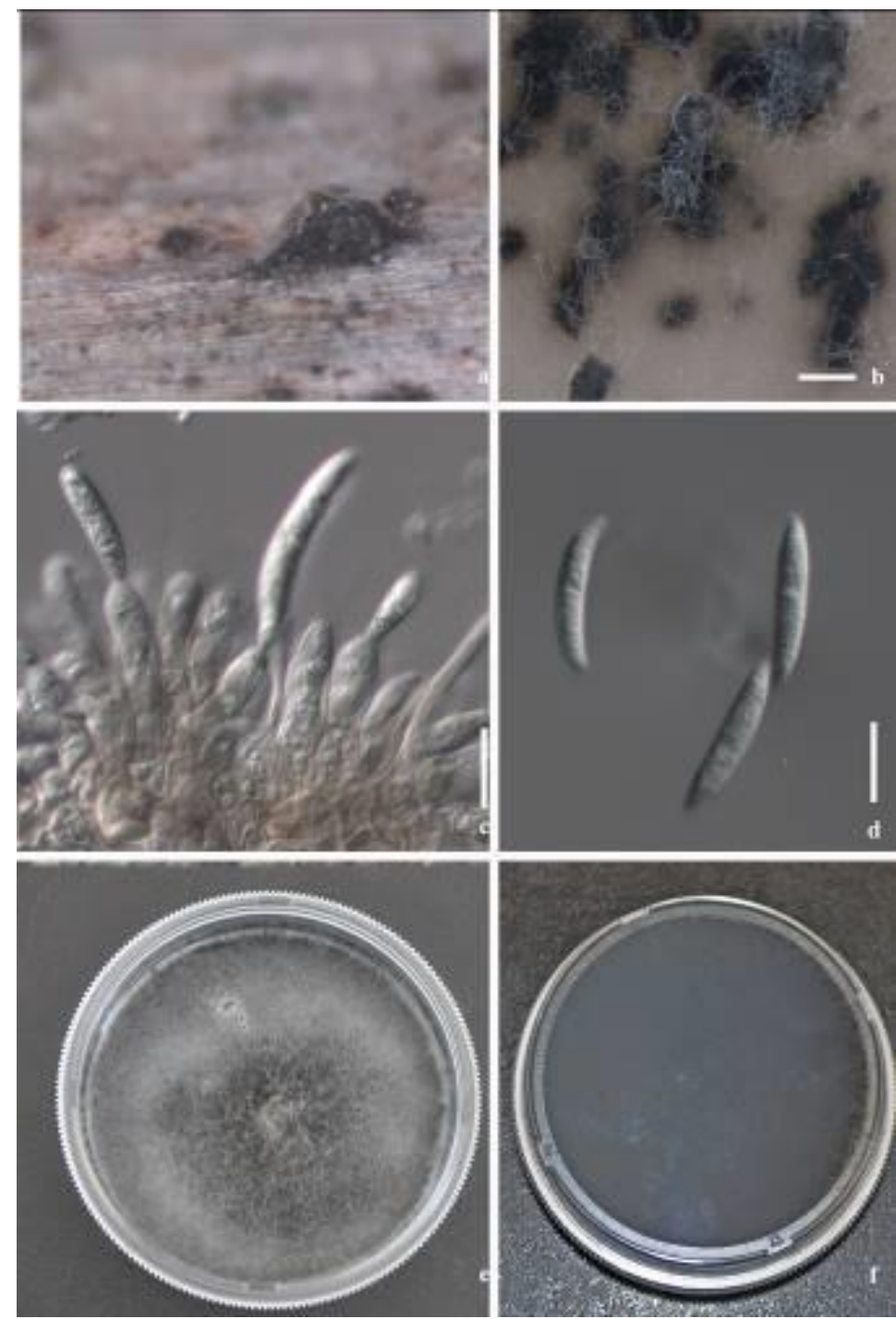

Fig. 61 - Colletotrichum dematium. a. Conidiomata on host. b. Conidiomata on PDA. c. Conidiophores and conidiogenous cells. d. Conidia. e. Upper view of 7 day old culture. f. Reverse view of 7 day old culture. Scale bars: $b-d=10 \mu \mathrm{m}$. 
Colletotrichum godetiae Neerg., Friesia 4(1-2): 72.1950.

Facesoffungi number: FoF 03881

Saprotrophic on dead and aerial branch of Vitis vinifera. Sexual morph: Not observed. Asexual morph: On PDA, Conidiomata absent, conidiophores form directly on hyphae. Vegetative hyphae 1-7 $\mu \mathrm{m}$, hyaline to pale brown, septate, branched, smooth-walled. Setae not observed. Conidiophores hyaline, smooth-walled, simple. Conidiogenous cells 5-11×3-7 $\mu \mathrm{m}(\bar{x}=7 \times 4 \mu \mathrm{m}$, $\mathrm{n}=20)$, hyaline, smooth-walled, cylindrical, often with short neck. Conidia $11-17 \times 4-6 \mu \mathrm{m}(\bar{x}=14 \times 5$ $\mu \mathrm{m}, \mathrm{n}=30$ ), $\mathrm{L} / \mathrm{W}$ ratio $=2.8$, cylindrical to fusiform, straight, hyaline, smooth-walled, acute at both ends or rarely one end rounded and one end slightly acute, aseptate. Conidial exudate salmon to orange.

Culture characteristics - Colonies on PDA, circular, flat, entire margin, initially white aerial mycelium, at maturity turns dark olivaceous-grey in the margin and white towards the centre, reverse greyish brown towards the margin and dark vinaceous buff to grey towards centre, reaching $3 \mathrm{~cm}$ diam. after 7 days at $20^{\circ} \mathrm{C}$.

Material examined - ITALY, Province of Forlì-Cesena, Fiumana - Predappio, on dead and aerial branch of Vitis vinifera, 13 February 2016, Erio Camporesi IT 2831 (MFLU 16-0879), culture, MFLUCC 16-1395, MFLUCC 17-1062.

Notes - Colletotrichum godetiae clustered in the Colletotrichum acutatum species complex (Jayawardena et al. 2016b). This species was invalidly described by Neergaard, from seeds of Clarkia hybrida cv. Kelvedon Glory,. and later validated with a Latin description (Neergaard 1950). In our phylogenetic analyses of combined ITS, GDPH, CHS, ACT and $\beta$-tubulin sequence data (Fig. 61), our isolates are in a well-defined clade with the type species of $C$. godetiae (CBS 133.44) with relatively high bootstrap and Bayesian probabilities (100\% MP/ $1.00 \mathrm{PP}$ ). Similar morphology was observed between our isolate and the type species of $C$. godetiae (CBS 133.44). The species has been mainly recorded from Europe, but it is also found in a few other countries, causing fruit, leaf and stem diseases (Jayawardena et al. 2016b). It was reported to cause anthracnose disease on Vitis vinifera (Baroncelli et al. 2014). This study provides the first record of $C$. godetiae as a saprotroph on $V$. vinifera in Italy.

Colletotrichum hebeiense X.H. Li, Y. Wang, K.D. Hyde, M.M.R.S. Jayawardena \& J.Y. Yan, in Yan, Jayawardena, Goonasekara, Wang, Zhang, Liu, Huang, Wang, Shang, Peng, Bahkali, Hyde \& Li, Fungal Diversity 71: 241 (2015)

Facesoffungi number: FoF 03828

Saprotrophic on dead shoots of Vitis vinifera. Sexual morph: Not observed. Asexual morph: Vegetative hyphae $2 \mu \mathrm{m}$ in diam, hyaline, smooth-walled, septate, branched. Conidiomata and setae not observed. Conidiogenous cells $6-25 \times 1-3 \mu \mathrm{m}(\bar{x}=15 \times 3 \mu \mathrm{m}, \mathrm{n}=10)$, hyaline, smoothwalled, cylindrical, opening $0.5-2 \mu \mathrm{m}$ diam, collarette $<0.4 \mu \mathrm{m}$ long, periclinal thickening visible to conspicuous. Conidia 12-15 $\times 4-7 \mu \mathrm{m}(\bar{x}=14 \times 5 \mu \mathrm{m}, \mathrm{n}=40)$, hyaline, smooth-walled, aseptate, straight, cylindrical to clavate, apex rounded, base rounded, L/W ratio=2.6. Appressoria not observed.

Culture characteristics - Colonies grown from single conidia on PDA white becoming grey, reverse yellow and becoming black, reaching a maximum of $80 \mathrm{~mm}$ diam. in 7 days at $28{ }^{\circ} \mathrm{C}$.

Material examined - CHINA, Beijing, on dead shoot of Vitis vinifera cv. Red Globe, 3 June 2015, Ruvishika Jayawardena, culture, JZB330117.

Notes - Colletotrichum hebeiense is described as a ripe rot pathogen of grapes in China (Yan et al. 2015). Our strain clustered with the type strain of $C$. hebeiense with a high bootstrap support (Fig. 67). This study provides the first record of $C$. hebeiense as a saprotroph on $V$. vinifera in China.

Colletotrichum siamense Prihast., L. Cai \& K.D. Hyde, in Prihastuti, Cai, Chen, McKenzie \& Hyde, Fungal Diversity 39: 98 (2009)

Facesoffungi number: FoF03599 
Saprotrophic on dead and aerial branches of Vitis vinifera. Sexual morph: Not observed. Asexual morph: Conidiomata 70-143 $\mu \mathrm{m}$ diam., brown to dark brown, acervulus, oval, solitary to aggregated. Setae absent. Conidiophores hyaline, cylindrical or clavate, smooth-walled, simple, to $80 \mu \mathrm{m}$ long. Conidiogenous cells 10-14 $\mu \mathrm{m}$ long, enteroblastic, hyaline, smooth-walled, cyllindrical to slighty inflated, Collarette $0.5-1 \mu \mathrm{m}$ long, periclinal thickening visible. Conidia $7-$ 19×3-4 $\mathrm{m}(\bar{x}=11 \times 4 \mu \mathrm{m}, \mathrm{n}=40)$ hyaline, smooth or verruculose, aseptate, guttulate, fusiform, ovoid to cylindrical or clavate with rounded apices. Appressoria not observed.

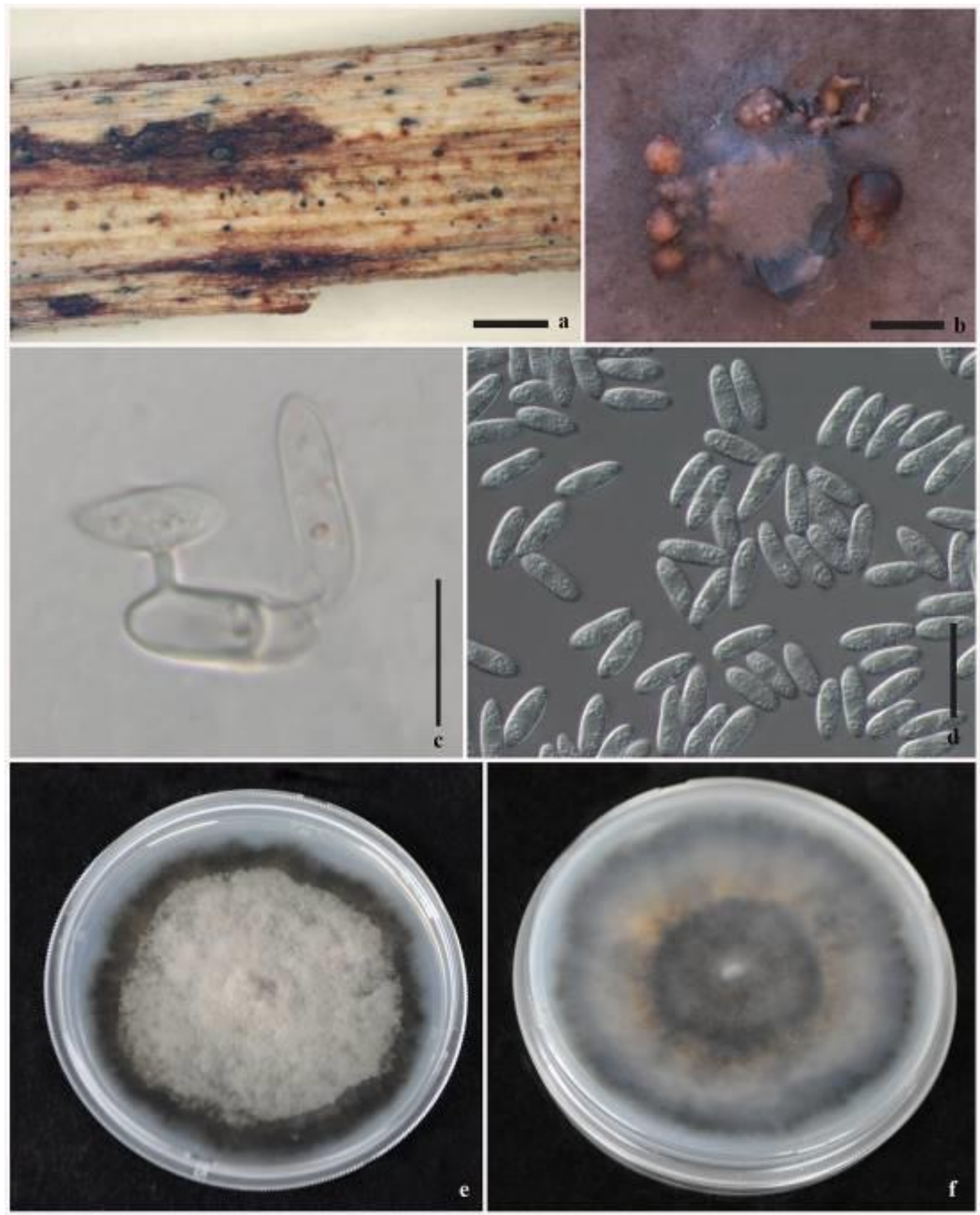

Fig. 62 -Colletotrichum godetiae. a. Host tissue from which the species was isolated. b. Orange coloured conidial exudate. c. Conidiogenesis. d. Conidia. e. Upper view. f. Reverse view of colony on PDA. Scale bars: $a=1 \mathrm{~mm}, \mathrm{~b}=2 \mathrm{~mm}, \mathrm{c}=10 \mu \mathrm{m}, \mathrm{d}=20 \mu \mathrm{m}$. 


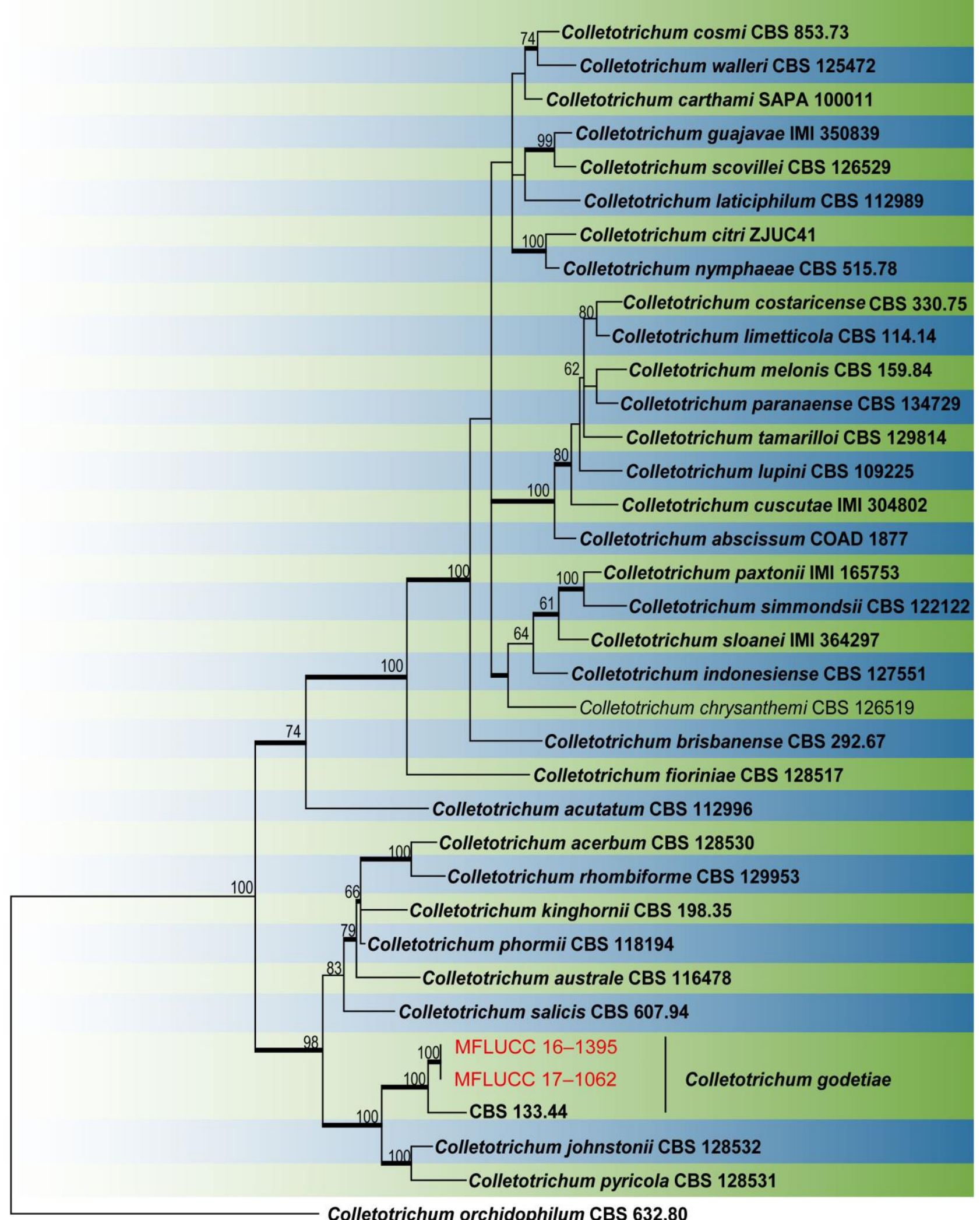

10

Fig. 63 - One of ten most parsimonious trees obtained from a heuristic search of combined ITS, GAPDH, CHS, ACT and TUB2 sequence data of taxa for the acutatum species complex. Parsimony bootstrap support values $\geq 50 \%$ are indicated at the nodes and branches with Bayesian posterior probabilities $\geq 0.90$ given in bold. Ex-type strains are in bold. Strains obtained in this study are in blue. The tree is rooted with Colletotrichum orchidophilum CBS 632.80. 

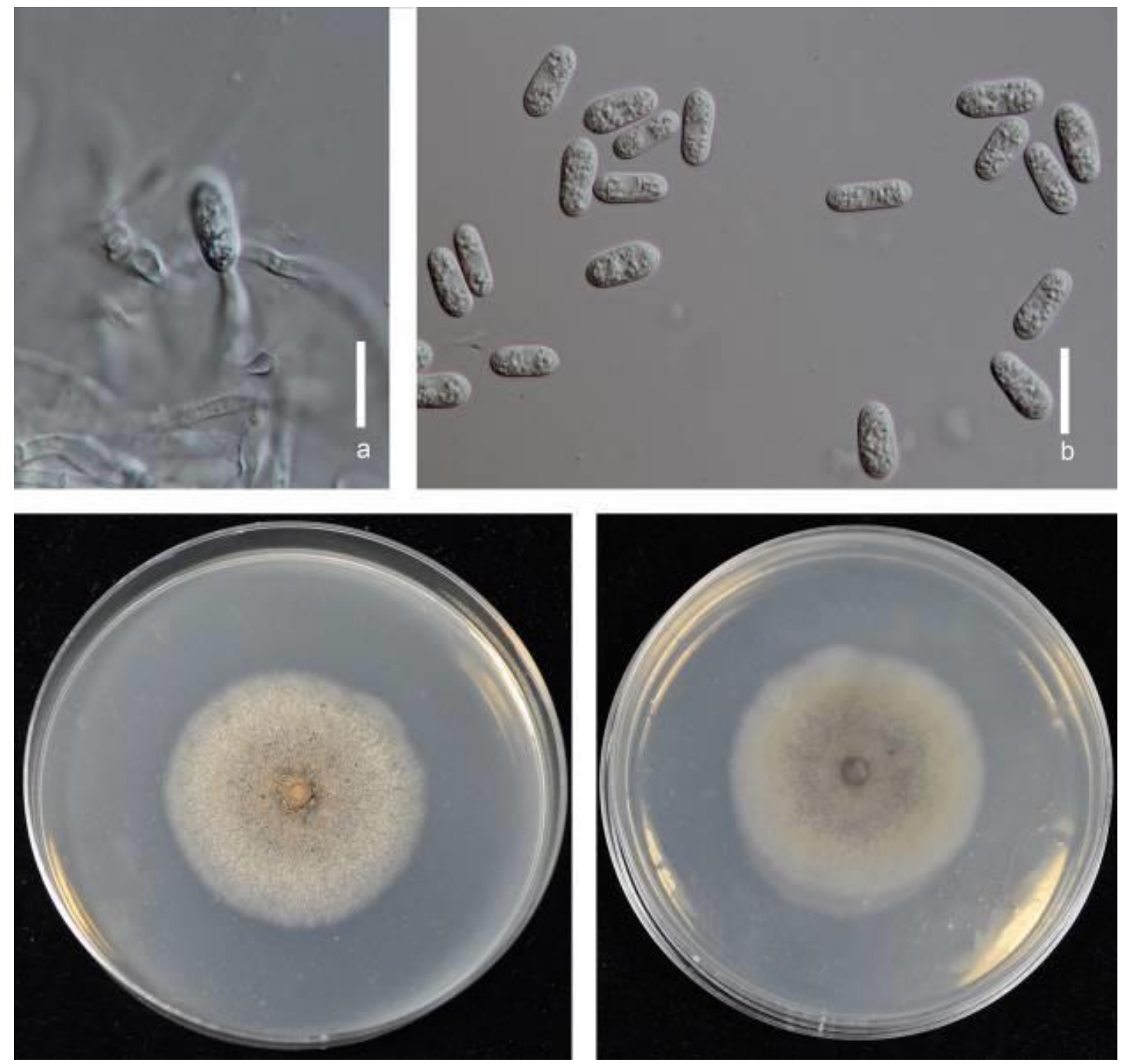

Fig. 64 - Colletotrichum hebeiense. a. Conidiophore. b. Conidia. c. Upper view of the colony. d. Reverse view of the colony. Scale bars: $\mathrm{a}-\mathrm{b}=10 \mu \mathrm{m}$.

Culture characteristics - Colonies on PDA reaching a maximum of $80 \mathrm{~mm}$ diam. in 7 days at $25^{\circ} \mathrm{C}$, at first white and becoming pale brownish to pinkish, reverse pale yellowish to pinkish, aerial mycelium greyish white, dense, cottony. Vegetative hyphae $2.1 \mu \mathrm{m}$ hyaline, smooth-walled, septate, branched.

Material examined - ITALY, Province of Forlì-Cesena, Teodorano - Meldola, on dead and aerial branch of Vitis vinifera, 15 February 2015, Erio Camporesi IT 2379 (MFLU 15-1085), culture, MFLUCC 17-1219.

Notes - Colletotrichum siamense has been recorded from USA associated with grape ripe rot (Weir et al. 2012). A strain in this study clustered with the type species of $C$. siamense (Fig. 67). This is the first record of $C$. siamense as a saprotroph of Vitis vinifera.

Colletotrichum viniferum L.J. Peng, L. Cai, K.D. Hyde \& Zi Y. Ying, Mycoscience 54(1): 36 (2013)

Facesoffungi number: FoF03600

Pathogen on cluster stems and fruits. Sexual morph: Not observed. Asexual morph: Conidiomata 48-143 $\mu \mathrm{m}$ diam., black, acervulus, oval, solitary to aggregated. Setae absent. Conidiophores hyaline to light brown, cylindrical or clavate, smooth-walled, simple, wide at the 
base, to $46 \mu \mathrm{m}$ long, occuring in densly arranged clusters. Conidiogenous cells enteroblastic, hyaline, smooth-walled, cyllindrical to slighty inflated, collarette $0.5-1 \mu \mathrm{m}$ long, periclinal thickening visible, Conidia $7-12 \times 2-6 \mu \mathrm{m}(\bar{x}=7 \times 4 \mu \mathrm{m}, \mathrm{n}=40)$, hyaline, smooth or verruculose, aseptate, ovoid to cylindrical or clavate with rounded apices. Appressoria formed in culture 9$16 \times 5-6 \mu \mathrm{m}(\bar{x}=13 \times 5 \mu \mathrm{m}, \mathrm{n}=10)$, solitary to aggregated, in small groups or short chains, medium to dark brown, smooth-walled, round, oval or irregular.
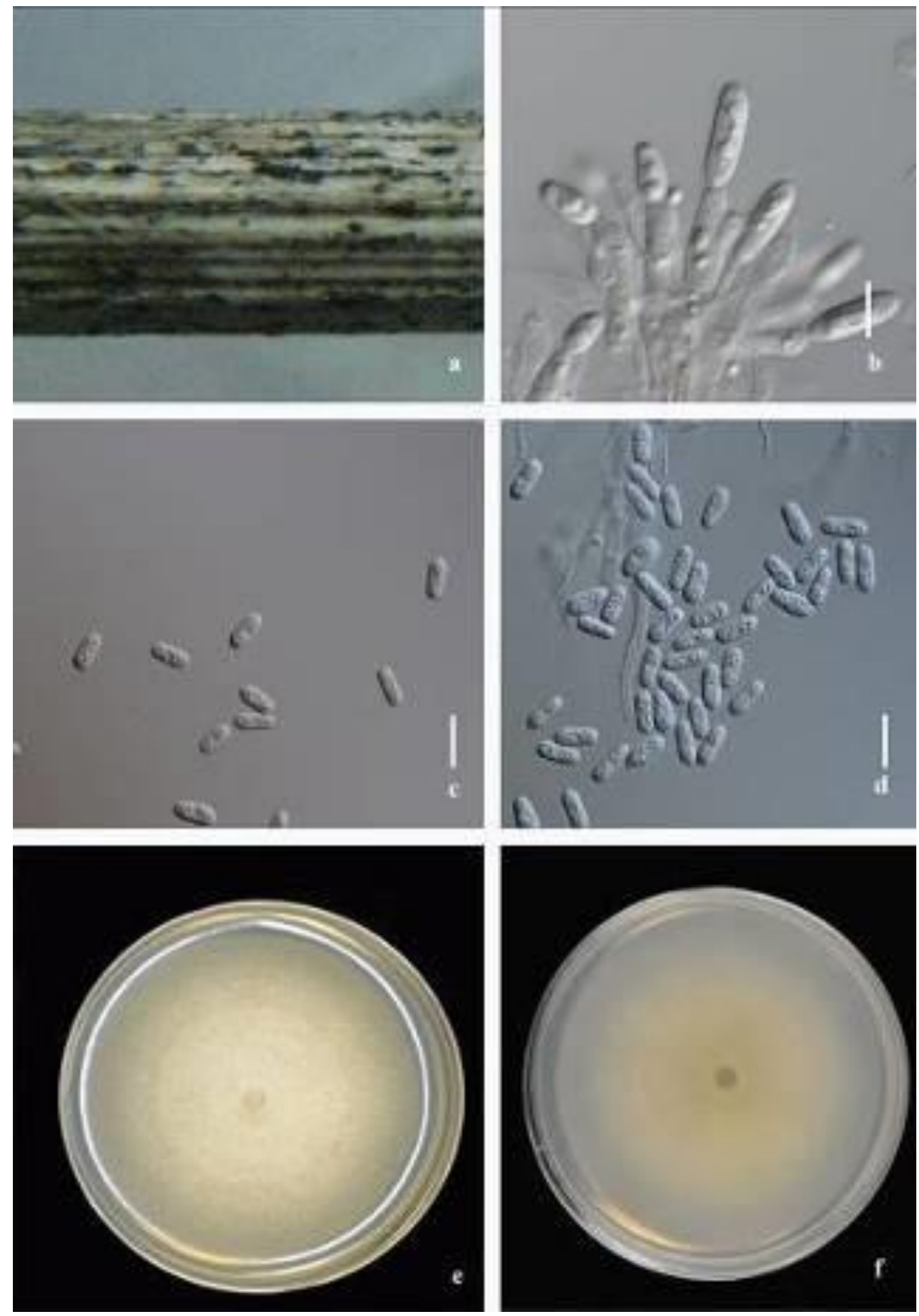

Fig. 65 - Colletotrichum siamense. a. Conidiomata on host. b. Conidiophores and conidiogenous cells. c-d. Conidia. e. Upper view of 7 day old culture on PDA. f. Reverse view of 7 day old culture on PDA. Scale bars: $b-d=10 \mu m$. 
Culture characteristics - Colonies on PDA reaching $75 \mathrm{~mm}$ diam. in 7 day at $25^{\circ} \mathrm{C}$, at first white becoming dark grey, reverse pale yellowish, aerial mycelium greyish white, dense, cottony, vegetative hyphae $2.1 \mu \mathrm{m}$ hyaline, smooth-walled, septate, branched.

Material examined - CHINA, Sichuan Province, Chengdou City, on cluster stem of Vitis labruscana, 12 August 2014, Liu Xiao SCCD7 (MFLU 15-0794), culture, MFLUCC 141213=CGMCC 3.17465; CHINA, Sichuan Province, Chengdou City, on cluster stem of $V$. labruscana, 12 August 2014, Liu Xiao SCCD2, SCCD3 and SCCD4 living cultures MFLUCC 141214, MFLUCC 14-1215 and MFLUCC 14-1216 respectively.

Notes - Colletotrichum viniferum was introduced by Peng et al. (2013). This species is a known pathogen causing grape ripe rot in China (Yan et al. 2015). Our strains clustered with the type species of $C$. viniferum with high bootstrap support (Fig. 67). This study provides the first report of $C$. viniferum as a pathogen on cluster stems.
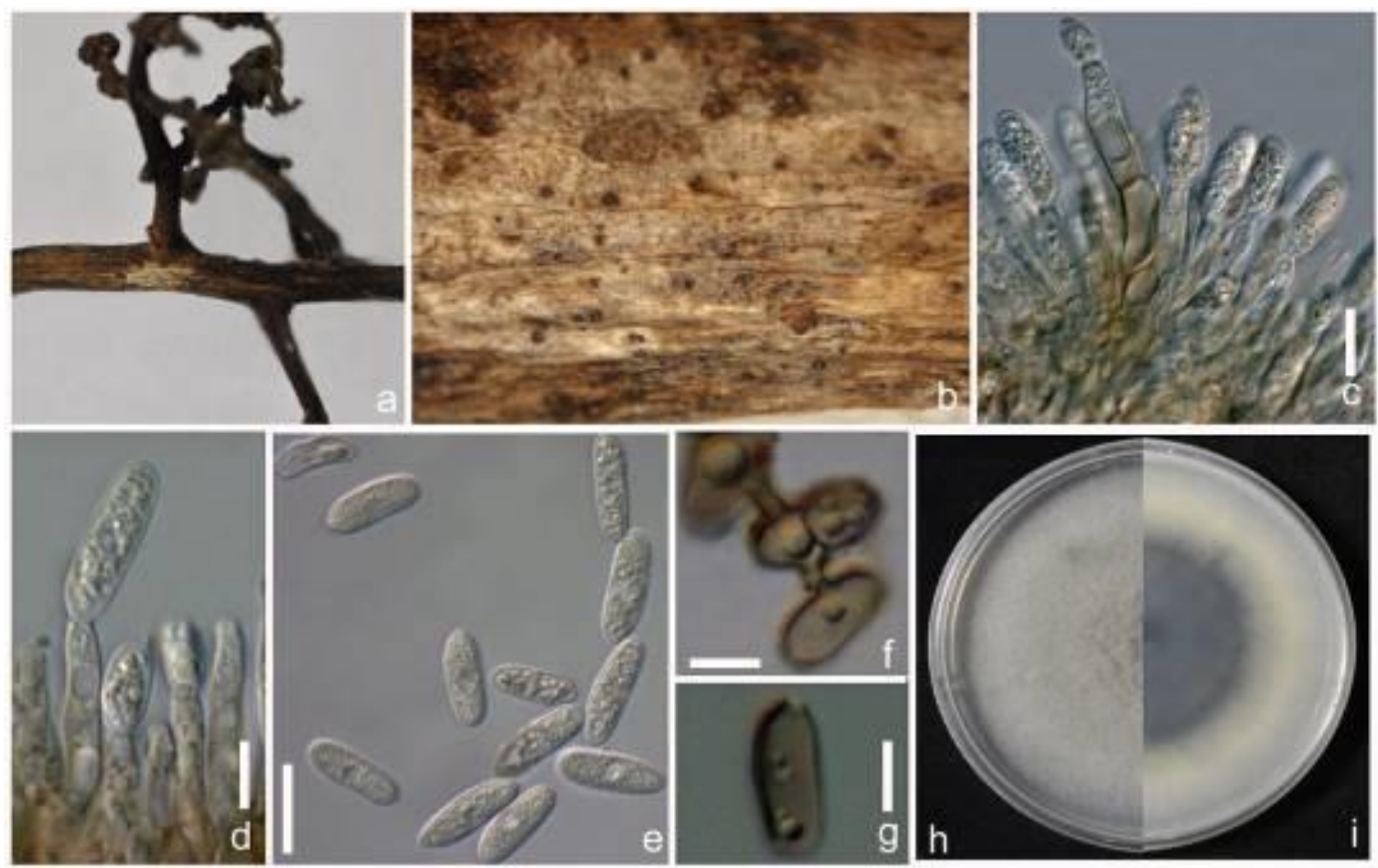

Fig. 66 - Colletotrichum viniferum. a. Bleached necrotic lesion on a cluster stem. b. Conidiomata. c-d. Conidiophores and conidiogenous cells. e. Mature conidia. f-g. Appressoria. h. Upper view of 7 day old culture. i. Reverse view of 7 day old culture. Scale bars: $c-g=5 \mu \mathrm{m}$.

Colletotrichum truncatum (Schwein.) Andrus \& W.D. Moore, Phytopathology 25: 121 (1935) Facesoffungi number: FoF03827

Saprotrophic on dead shoot of Vitis vinifera. Sexual morph: Not observed. Asexual morph: Conidiomata acervular, conidiophores and setae formed directly on hyphae. Setae hyaline to pale brown, smooth to verruculose, 80-130 $\mu \mathrm{m}$ long, 2-5-septate, tapering slightly towards the slightly acute to round tip, base cylindrical to conical, 4-5 $\mu \mathrm{m}$ diam. Conidiophores hyaline to pale brown, septate, strongly branched, densely clustered, up to $90 \mu \mathrm{m}$ long. Conidiogenous cells

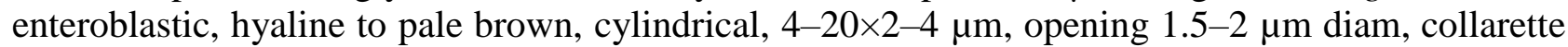


rarely visible, periclinal thickening not observed. Conidia hyaline, smooth-walled to verruculose, aseptate, long central part of conidia usually slightly curved with parallel walls, ending abruptly at the round and truncate base, tapering towards the acute and more strongly curved apex, 17-30 $\times 3-4$ $\mu \mathrm{m},(\bar{x}=22 \times 4) \mathrm{L} / \mathrm{W}$ ratio $=5.7$.

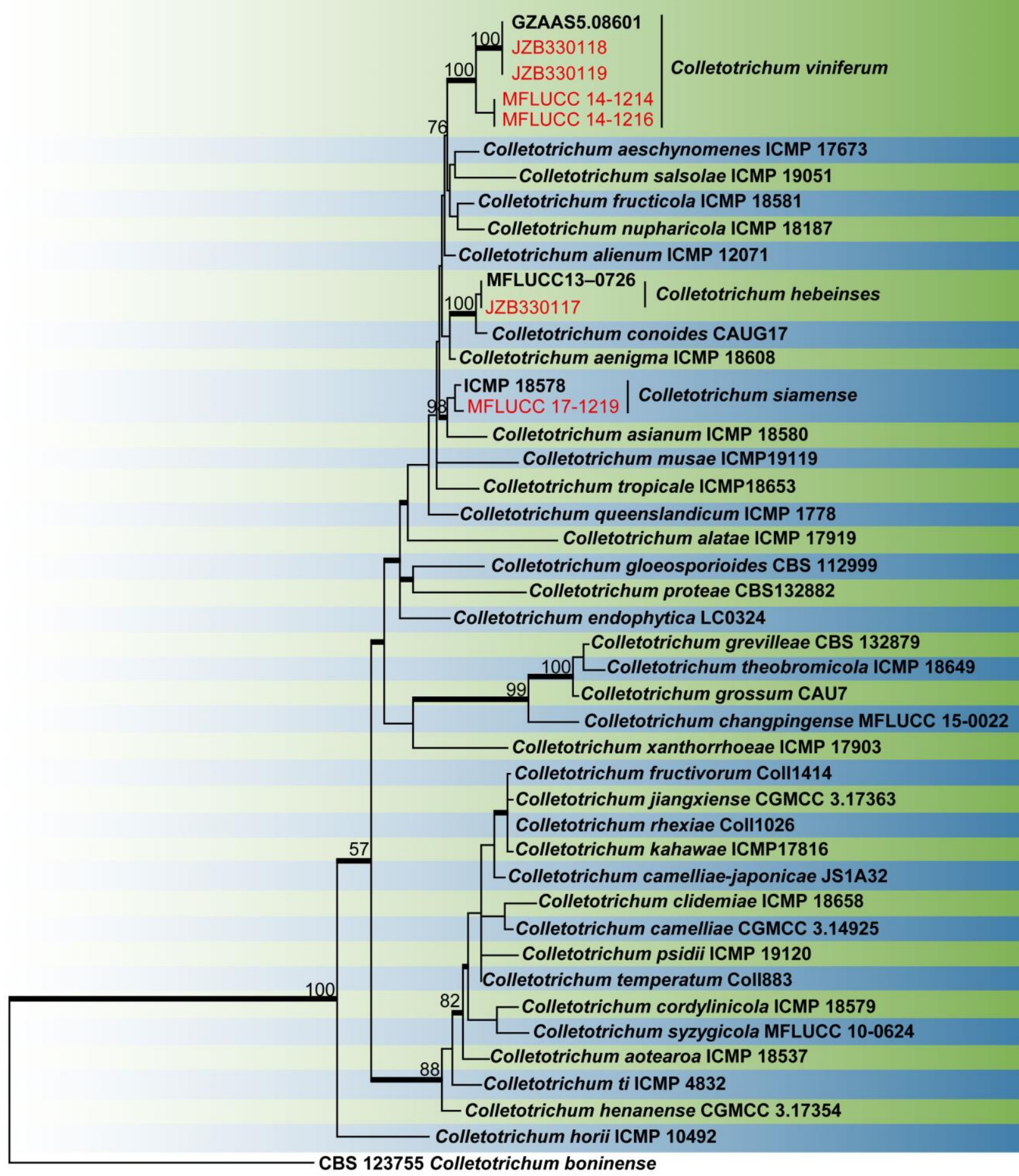

10

Fig. 67 - One of ten most parsimonious trees obtained from a heuristic search of combined ITS, GAPDH, CHS, ACT and TUB2 sequence data of taxa for the gloeosporioides species complex. Parsimony bootstrap support values $\geq 50 \%$ are indicated at the nodes and branches with Bayesian posterior probabilities $\geq 0.90$ are given in bold. Ex-type strains are in bold. Strains obtained in this study are in blue. The tree is rooted with Colletotrichum boninense CBS 123755. 
Culture characteristics - Colonies on PDA reaching a maximum of $50 \mathrm{~mm}$ diam. in 7 days at 25 ${ }^{\circ} \mathrm{C}$, flat with an entire margin.

Material examined - CHINA, Beijing, on dead shoot of Vitis vinifera cv. Red Globe, 3 June 2015, Ruvishika Jayawardena, culture, MFLUCC 17-2380.

Notes - Colletotrichum truncatum is a pathogen of Capsicum sp. as well as on other economically important crops (Jayawardena et al. 2016b). This species has been recorded from Italy and Switzerland as a pathogen causing grape ripe rot (Pan et al. 2016), and as an endophyte from India (Farr 1973). Our strain clustered with the type strain of $C$. truncatum (Fig. 69). This is the first record of $C$. truncatum as a saprotroph on Vitis vinifera in China.
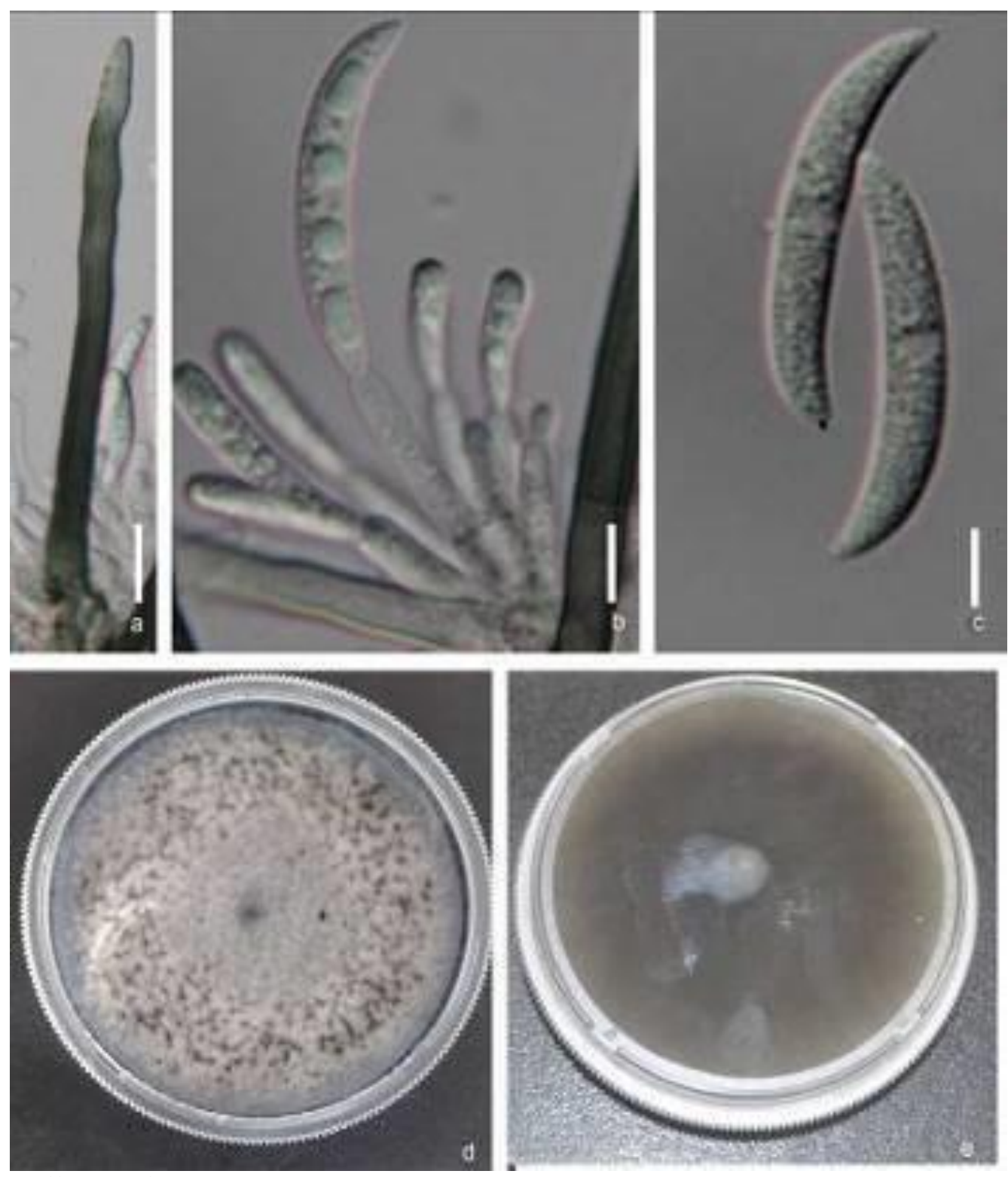

Fig. 68 - Colletotrichum truncatum. a. Seta. b. Conidiophore and conidiogenous cells. c. Conidia. d. Upper view of colony on PDA. e. Reverse view of colony on PDA. Scale bars: $a=10 \mu \mathrm{m}$.

Xylariales Nannf., Nova Acta R. Soc. Scient. upsal., Ser. 4 8(no. 2): 66 (1932)

Diatrypaceae Nitschke [as 'Diatrypeae'], Verh. naturh. Ver. preuss. Rheinl. 26: 73 (1869)

Diatrypaceae was introduced to accommodate Diatrype. Fungal taxa belonging to this family can produce extracellular ligninolytic enzymes, showing a physiological capacity in decaying wood (Trouillas et al. 2011). Currently this family comprises 15 genera (Maharachchikumbura et al. 2016a, Wijayawardene et al. 2018). Several genera in the 
Diatrypaceae (Cryptovalsa, Diatrype, Diatrypella, Eutypa and Eutypella) are known to occur on grapevines worldwide (Luque et al. 2005).

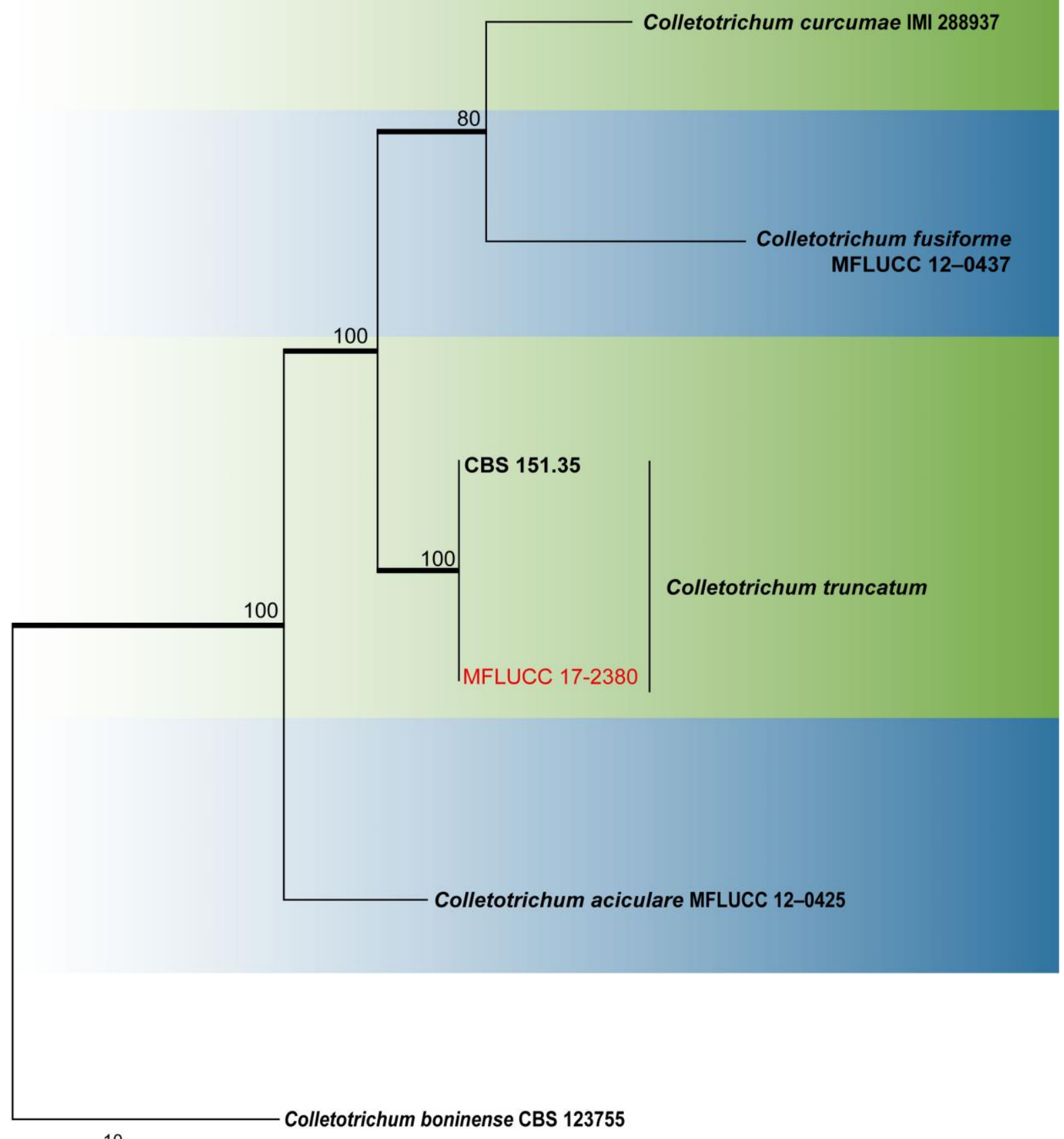

Fig. 69 - One of ten most parsimonious trees obtained from a heuristic search of combined ITS, GAPDH, CHS, ACT and TUB2 sequence data of taxa for the gloeosporioides species complex. Parsimony bootstrap support values $\geq 50 \%$ are indicated at the nodes and branches with Bayesian posterior probabilities $\geq 0.90$ given in bold. Ex-type strains are in bold. Strains obtained in this study are in red. The tree is rooted with Colletotrichum boninense CBS 123755.

Cryptovalsa Ces. \& De Not. ex Fuckel, Jb. nassau. Ver. Naturk. 23-24: 212 (1870) [1869-70]

Species of Cryptovalsa are saprotrophs or pathogens worldwide (Wijayawardene et al. 2017). This is a common genus occurring on grapevine. Cryptovalsa is characterized by eutypoid ascostromata, polysporous asci and allantoid ascospores (Spooner 1981). Our strains clustered with the reference sequence of $C$. ampelina (Fig. 70). We provide a description of both the sexual and asexual morph of this species. 


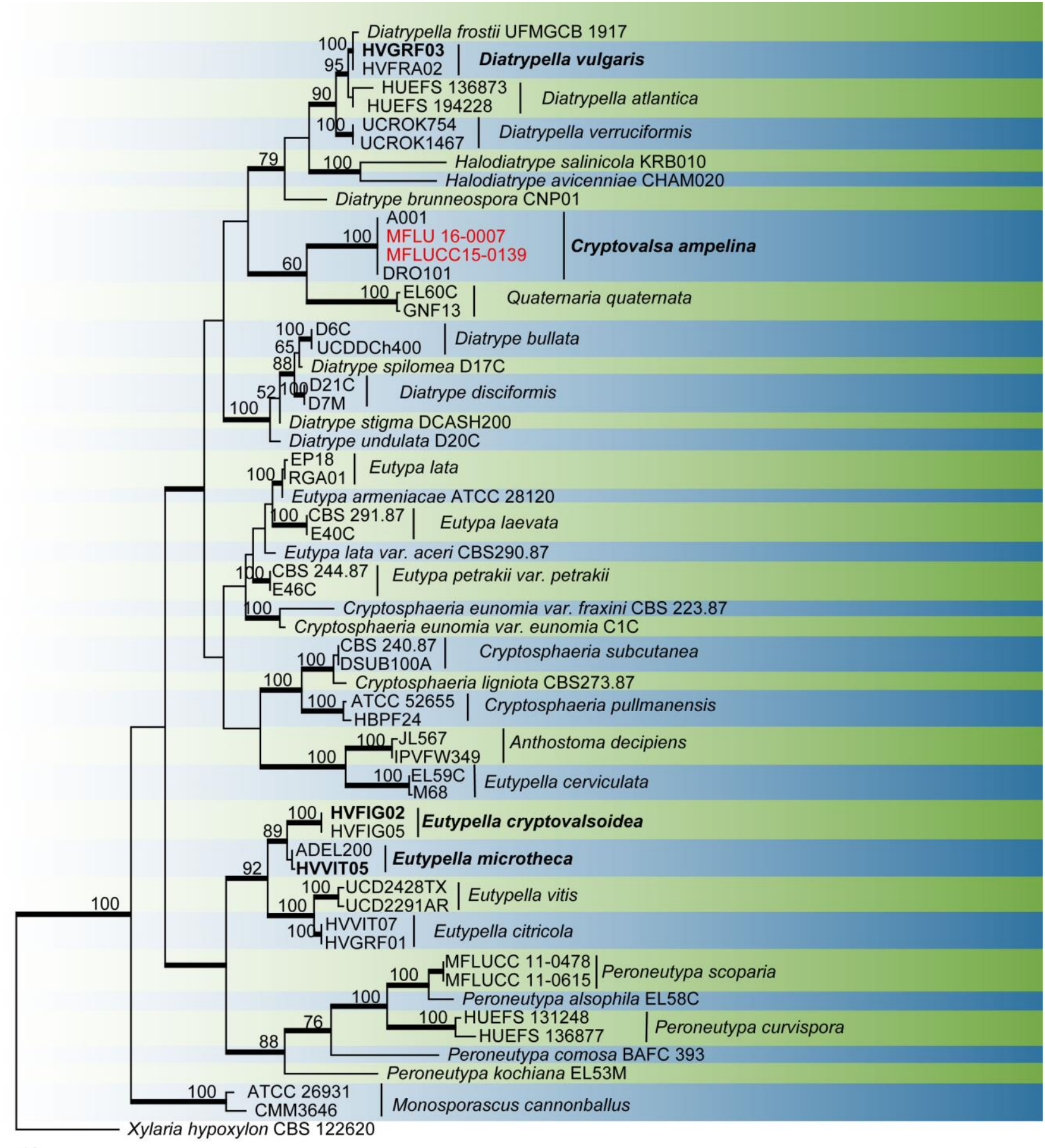

\section{0}

Fig.70 - One of ten most parsimonious trees obtained from a heuristic search of combined ITS and TUB2 sequence data of taxa from the Diatrypaceae. Parsimony bootstrap support values above 50 $\%$ are indicated at the nodes and branches with Bayesian posterior probabilities above 0.75 are given in bold. Ex-type strains are in bold. Strains obtained in this study are in red. The tree is rooted with Diaporthe foeniculiana CBS 111553.

Cryptovalsa ampelina (Nitschke) Fuckel, Jb. nassau. Ver. Naturk. 23-24: 212 (1870) [1869-70]

Facesoffungi number: FoF 01800

Saprotrophic on dead stem of Vitis vinifera. Sexual morph: Stromata poorly developed, immersed in bark, occasionally with protruding perithecial necks, single or in groups, irregularly scattered. Ascomata 350-380 $\mu \mathrm{m}$ high $\times 130-170 \mu \mathrm{m}$ diam. $(\bar{x}=360 \times 260 \mu \mathrm{m}, \mathrm{n}=10)$, solitary to gregarious, immersed, dark brown to black, globose to pyriform, raising above the epidermis and forming black, blister-like areas, often compressed, ostiolate. Papilla 125-140 $\mu \mathrm{m}$ high, 90-100 
$\mu \mathrm{m}$ wide $(\bar{x}=138 \times 96 \mu \mathrm{m}, \mathrm{n}=10)$, central, long, internally covered by periphyses. Peridium 20-26 $\mu \mathrm{m}$ wide $(\bar{x}=25 \mu \mathrm{m}, \mathrm{n}=10)$. Peridium $35-45 \mu \mathrm{m}$ wide, composed of two types of layers; 9-11 outer layers, thick, with dark brown to black cells of textura angularis and 3-5 inner layers of hyaline cells. Hamathecium composed of dense, $2-4 \mu \mathrm{m}$ wide, hyaline, aseptate, anastomosing paraphyses. Asci $120-135 \times 10-13 \mu \mathrm{m}(\bar{x}=130 \times 13 \mu \mathrm{m}, \mathrm{n}=20)$, unitunicate, 32 ascospores per ascus, elongateclavate, with long pedicel, with $\mathrm{J}+$ apical ring. Ascospores $10-15 \times 2-4 \mu \mathrm{m}(\bar{x}=12 \times 3 \mu \mathrm{m}, \mathrm{n}=20)$, overlapping to irregular, yellowish to light brown at maturity, allantoid, 1-celled, smooth-walled, with small guttules. Asexual morph: Coelomycetous, occurring in culture as pycnidia. Conidiomata superficial, solitary or aggregated, dark brown to black, globose to subglobose, with yellow to light brown interwoven, thick-walled hyphae. Conidiophores septate, bicellately to verticillately branch, arranged in dense palisades, cylindrical, hyaline, smooth, arising from the base. Conidiogenous cells 5-16 $\times 1-2 \mu \mathrm{m}(\bar{x}=12 \times 1 \mu \mathrm{m}, \mathrm{n}=20)$, holoblastic, straight or curved, apically distorted on conidial secession. Conidia $17-30 \times 1-1.5(\bar{x}=22 \times 1 \mu \mathrm{m}, \mathrm{n}=30)$, filiform, curved, or rarely straight with flattened base and blunt apex, hyaline.

Cultural characteristics - Ascospores germinating on MEA within 24 hours. Germ tubes produced at germ pore. Colonies on MEA reaching $4.0 \mathrm{~mm}$ diam after 7 days at $25^{\circ} \mathrm{C}$, edge entire, flat or effuse or umbonate.

Material examined - ITALY, Province of Forlì-Cesena, Fiumana di Predappio, on dead stem of Vitis vinifera, 4 February 2014, Erio Camporesi, IT 1698 (MFLU 16-0007), living culture, MFLUCC15-0139.

Notes - Cryptovalsa ampelina is associated with Eutypa dieback in major grape growing countries (Trouillas et al. 2010). This is the most studied species in the genus and the only species to have molecular data available.

Hypocreales Lindau, in Engler \& Prantl, Nat. Pflanzenfam., Teil. I (Leipzig) 1(1): 343 (1897)

Hypocreaceae De Not., G. bot. ital. 2(1): 48 (1844)

Seaver $(1909,1911)$ divided Hypocreales into two families, Nectriaceae and Hypocreaceae Maharachchikumbura et al. (2016a) listed 18 genera under Hypocreaceae.

Trichoderma Pers., Neues Mag. Bot. 1: 92 (1794)

Members of this genus are saprotrophs or hypersaprotrophs on various plants and on other fungi (Maharachchikumbura et al. 2016a). Hypocrea has been synonymized under this genus.

Trichoderma atroviride P. Karst., Bidr. Känn. Finl. Nat. Folk 51: 363 (1892)

This study provides the first record of $T$. atroviride on $V$. vinifera as a saprotroph.

Trichoderma lixii (Pat.) P. Chaverri, in Chaverri, Branco Rocha, Jaklitsch, Gazis, Degenkolb \& Samuels, Mycologia 107(3): 578 (2015)

This is the first record of $T$. lixii on $V$. vinifera as a saprotroph.

Trichoderma harzianum Rifai, Mycol. Pap. 116: 38 (1969)

Trichoderma harzianum has been recorded from $V$. vinifera as an endophyte from Spain (Gonzalez \& Tello 2011). This is the first record of $T$. harzianum from $V$. vinifera as a saprotroph in China.

Nectriaceae Tul. \& C. Tul. [as 'Nectriei'], Select. fung. carpol. (Paris) 3: 3 (1865)

Petch (1938) accepted Nectriaceae as a separate family in Hypocreales. Nectriaceae is characterized by uniloculate, pigmented ascomata and phialidic amerosporous to phragmosporous conidia (Maharachchikumbura et al. 2016a). 


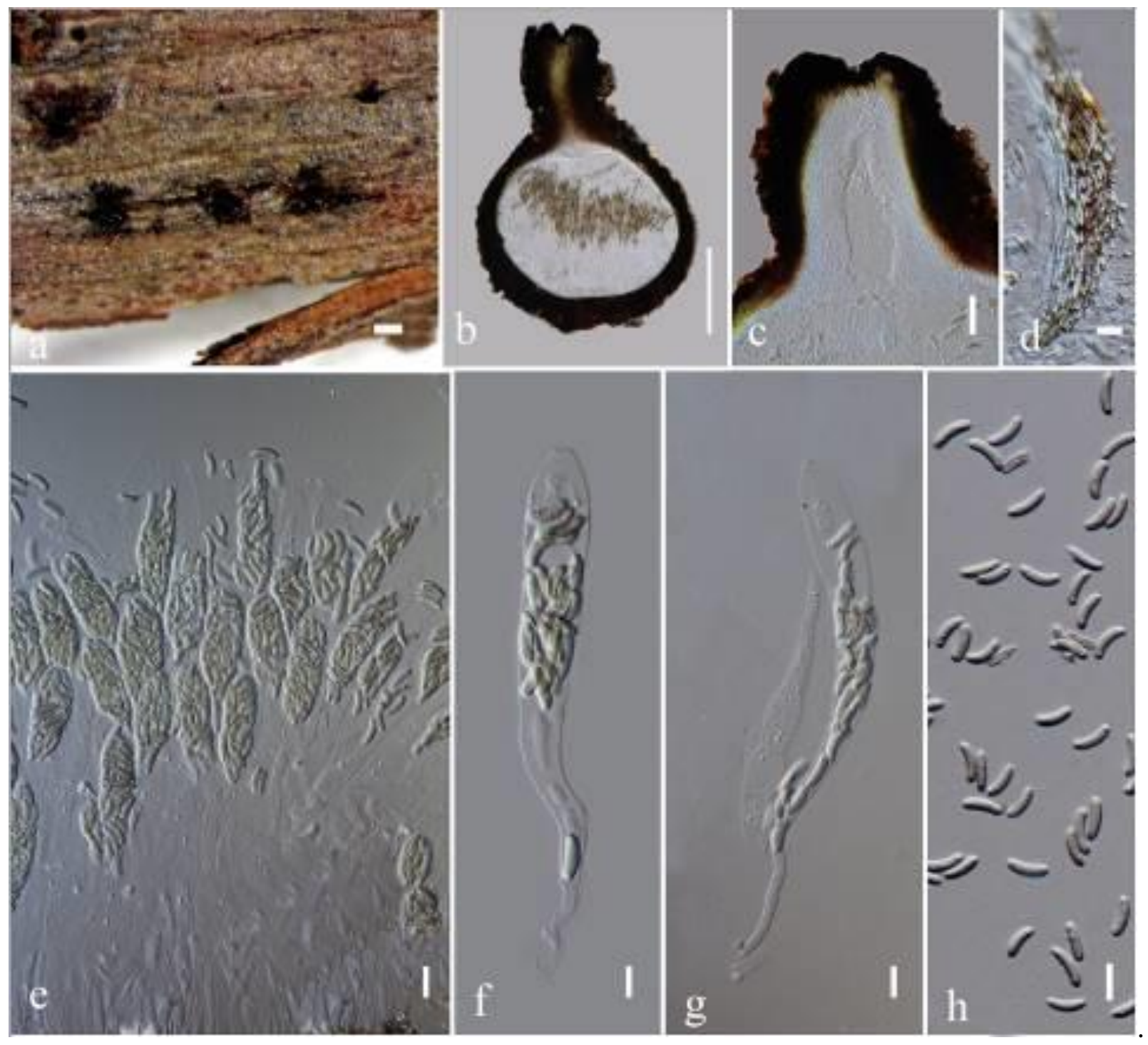

Fig. 71 - Cryptovalsa ampelina. a. Ascomata on substrate. b. Cross section of ascoma. c. Papilla d. Peridium e-g. Asci. h. Ascospores. Scale bars: $a=200 \mu \mathrm{m}, \mathrm{b}=100 \mu \mathrm{m}, \mathrm{c}=50 \mu \mathrm{m}, \mathrm{d}-\mathrm{h}=10 \mu \mathrm{m}$.

\section{Fusarium Link}

Fusarium was described by Link (1809). Species belonging to this genus develop five distinct type of propagules. Strains from our study, based on ITS sequence data, appear to be $F$. oxysporum and F. sambucinum (Fig. 75)

Fusarium oxysporum Schltdl., Fl. berol. (Berlin) 2: 139 (1824)

Notes - Fusarium oxysporum is a well-known pathogen on grapevine (Gonzalez \& Tello 2011, Jayawardena et al. 2018).

Fusarium sambucinum Fuckel, Jb. nassau. Ver. Naturk. 23-24: 167 (1870) [1869-70]

Facesoffungi number: FoF03129

Saprotrophic on dead branch of woody host. Sexual morph Not observed. Asexual morph Hyphae hyaline, septate. Conidiomata not observed in culture. Conidiophores reduced to conidiogenous cells. Conidiogenous cells integrated, terminal, cylindrical, variable in size. Macroconidia uncommon. Microconidia numerous, small terminal conidia, subglobose, 4-6 ( $\bar{x}=5$, $\mathrm{n}=40) \times 2-4(\bar{x}=3, \mathrm{n}=40) \mu \mathrm{m}$, aseptate. Chlamydospores globose, $3.3 \mu \mathrm{m}$ in diam, solitary.

Culture characteristics - Colonies on PDA reaching 3-5 cm diam., after 5 days at $25{ }^{\circ} \mathrm{C}$ undulate, whitish puffy colonies on top view, reverse yellowish with white halo margin. 
Material examined - Italy, Ontola - Predappio, Forlì-Cesena, on dead, aerial branch of Vitis vinifera, 11 April 2016, Erio Camporesi, IT 2931 (MFLU 16-1167), living culture MFLUCC 171057.

Notes - Fusarium includes species that are very important as plant pathogens. Several species or species complexes are involved in diseases of humans (Leslie \& Summerell 2006). In phylogenetic analysis, the present isolates cluster together with Fusarium sambucinum, with 100\% bootstrap support and 1.0 Bayesian posterior probability. Our isolate produced microconidia on PDA, which is a rare character for $F$. sambucinum. Another discrete character from type species is solitary chlamydospores. This study provides the first report of $F$. sambucinum associated with $V$. vinifera in Italy.
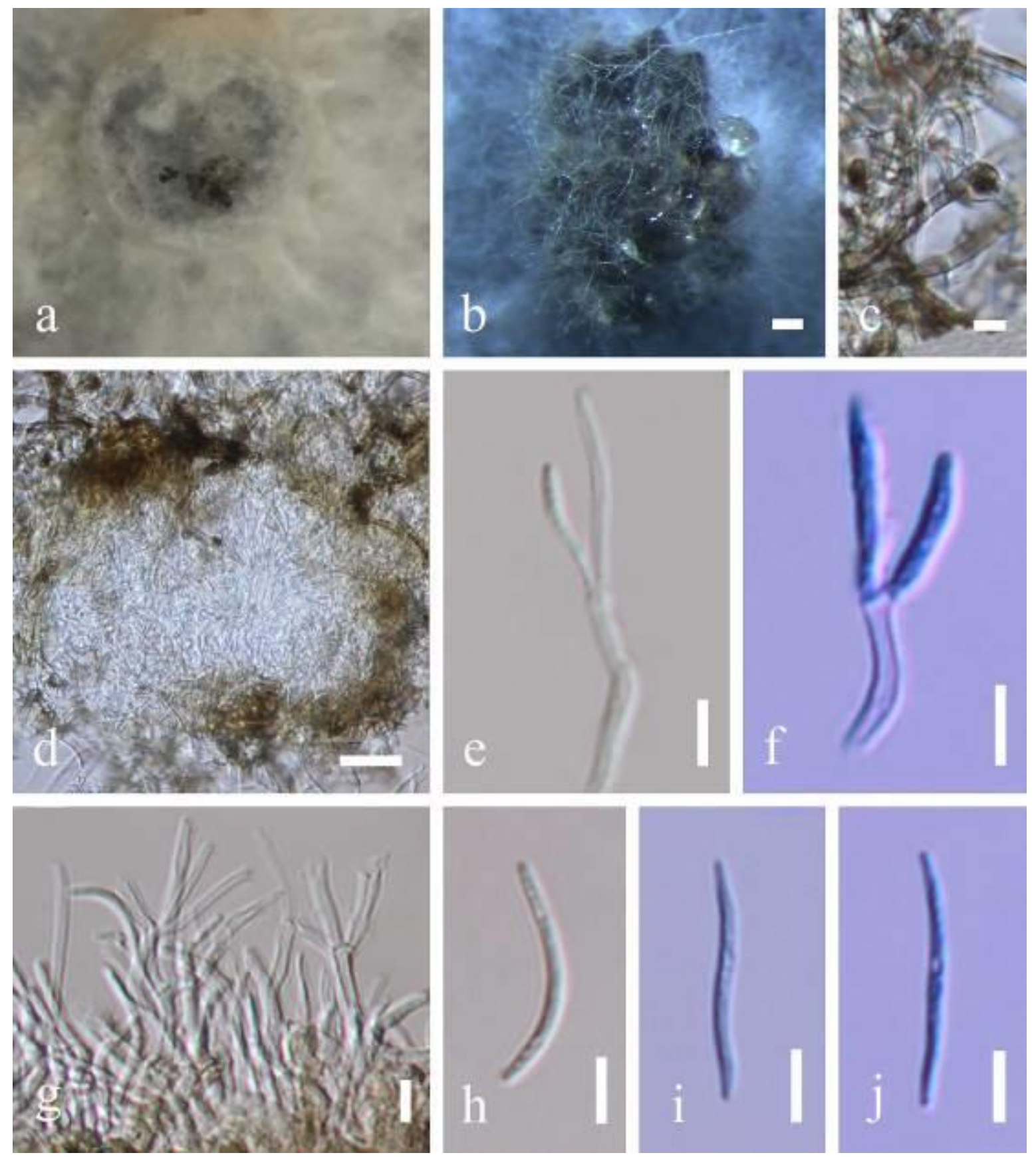

Fig. 72 - Culture on PDA Cryptovalsa ampelina. a, b. Conidiomata on the culture c. Hyphae on conidioma surface d. Section of conidioma e. Conidiophore with young conidium $\mathrm{f}$. Conidiogenous cell with conidia g. Conidiophores $h-j$. Conidia. (note: $f, i, j$ in cotton blue) Scale bars: $b=200 \mu m$, $\mathrm{d}=20 \mu \mathrm{m}, \mathrm{c}, \mathrm{e}-\mathrm{j}=5 \mu \mathrm{m}$. 

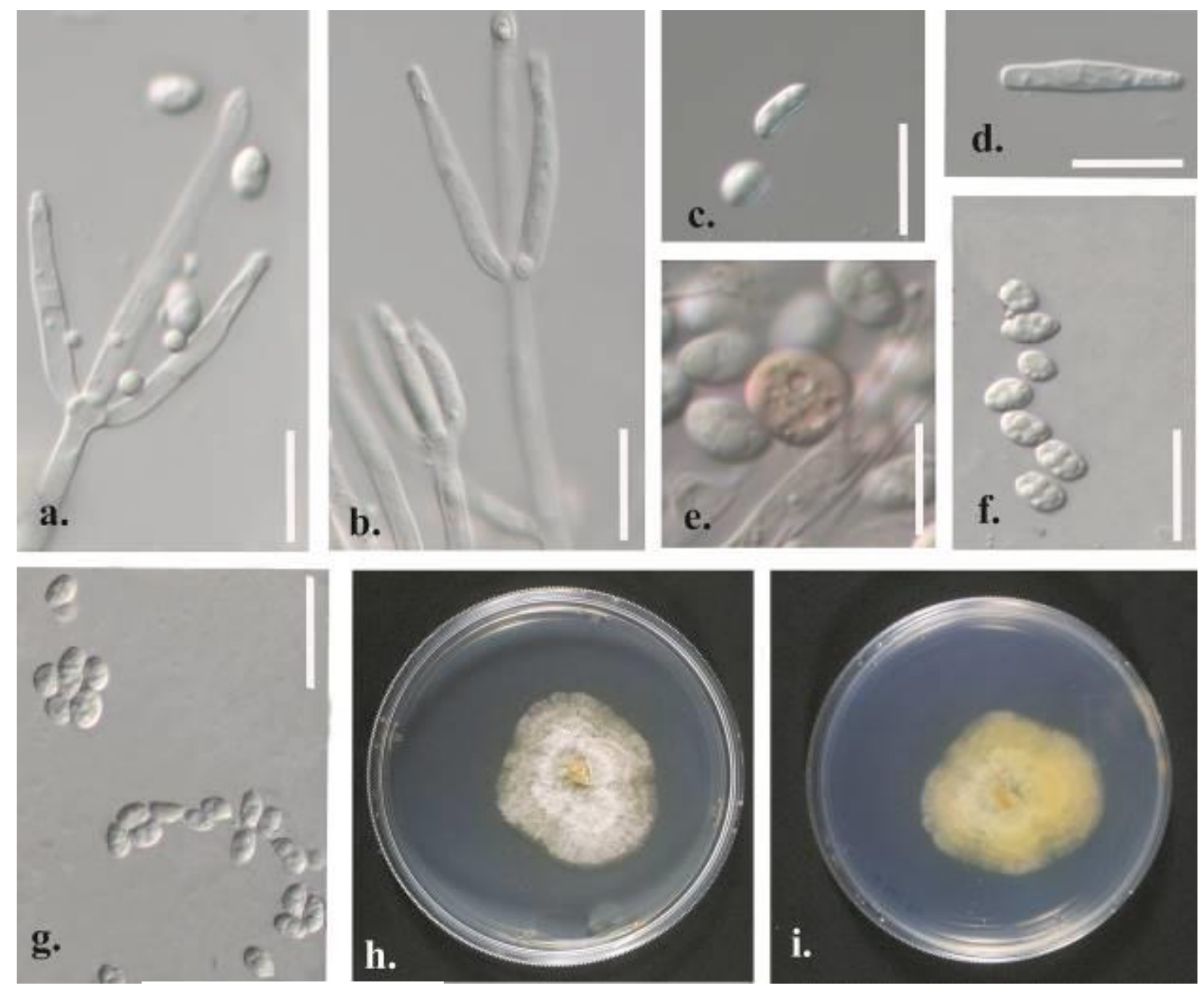

Fig. 76 - Fusarium sambucinum. a-b. Penicillate conidiogenous cells. c-d. Macroconidia. e. Chlamydospore. f-g. Conidia. h-i. Upper and reverse view on PDA. Scale bars: $\mathrm{a}-\mathrm{g}=10 \mu \mathrm{m}$.

Stachybotryaceae L. Lombard \& Crous, in Crous et al., Persoonia, Mol. Phyl. Evol. Fungi 32: 283 (2014)

Stachybotryaceae was introduced by Crous et al. (2014), in the order Hypocreales, to accommodate the genera Myrothecium, Peethambara and Stachybotrys.

Albifimbria L. Lombard \& Crous, in Lombard, Houbraken, Decock, Samson, Meijer, Réblová, Groenewald \& Crous, Persoonia 36: 177 (2016)

Members of Albifimbria are characterised by the formation of verrucose setae surrounding the sporodochia and conidia sometimes bearing a funnel-shaped mucoid appendage (Lombard et al. 2016). Our strains clustered with the type strains of A. verrucaria and A. viridis (Fig. 81).

Albifimbria verrucaria (Alb. \& Schwein.) L. Lombard \& Crous, in Lombard, Houbraken, Decock, Samson, Meijer, Réblová, Groenewald \& Crous, Persoonia 36: 177 (2016)

Facesoffungi number: FoF03833

For description see Tulloch (1972).

Notes: This study is the first record of $A$. verrucaria as a saprotroph, on $V$. vinifera from China.

Albifimbria viridis L. Lombard \& Crous, in Lombard, Houbraken, Decock, Samson, Meijer, Réblová, Groenewald \& Crous, Persoonia 36: 178 (2016) 
Facesoffungi number: FoF03834

For description see Lombard et al. (2016).

Notes: This study is the first record of $A$. viridis as a saprotroph, on $V$. vinifera from China.

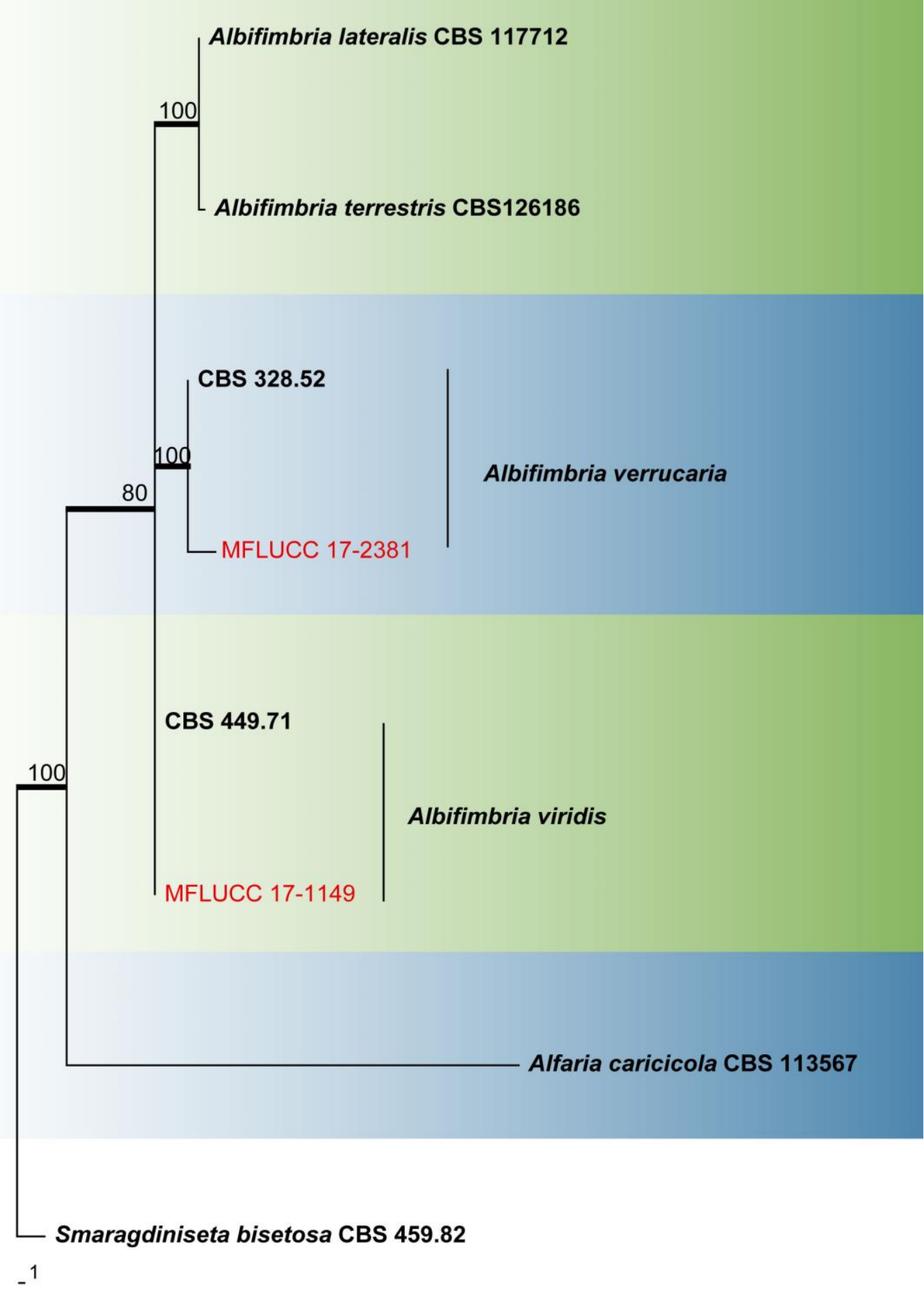

Fig. 77 - One of seven most parsimonious trees obtained from a heuristic search of combined ITS, and LSU sequence data of taxa of Albifimbria. Parsimony bootstrap support values $\geq 50 \%$ are indicated at the nodes and branches with Bayesian posterior probabilities $\geq 0.90$ are given in bold. Ex-type strains are in bold. Strains obtained in this study are in red. The tree is rooted with Smaragdiniseta bisetosa CBS 459.82.

\section{Hypocreales genera incertae sedis}

Alfaria Crous, N.J. Montaño-Mata \& García-Jim., in Crous et al., Persoonia 32: 239 (2014) 
This genus was introduced by Crous et al. (2014) associated with leaf apical necrosis of Cyperus esculentus. In this study we describe the asexual morph of A. cyperi-esculenti and introduce a new species, A. vitis (Fig. 80).

Alfaria cyperi-esculenti Crous, Montaño-Mata \& García-Jim., in Crous et al., Persoonia 32: 239 (2014)

Facesoffungi number: FoF03602

Saprotrophic on dead branches of Vitis vinifera. Sexual morph: Not observed. Asexual morph: Conidiomata sporodochial, stromatic, superficial, cupulate to discoid, scattered to gregarious, oval to elongate or irregular in outline, 150-450 $\mu \mathrm{m}$ diam, 35-80 $\mu \mathrm{m}$ deep. Stroma well-developed, hyaline, composed of cells of textura globulosa or textura angularis. Setae arising from the basal stroma of two kinds: Type I scattered among the conidiogenous cells, hypha-like, thin-walled, hyaline, septate, unbranched, smooth, flexuous, with obtuse or rounded apices, 50-70 $\mu \mathrm{m}$ long, 2-5 $\mu \mathrm{m}$ wide; and Type II originating from the fringe, thick-walled, pigmented towards the bottom third, smooth, 1-3-septate, unbranched, straight, narrowing to sharp apices, 60-100 $\mu \mathrm{m}$ long, 3-5 $\mu \mathrm{m}$ wide at the broadest part. Conidiophores arising from the basal stroma, unbranched or branched, hyaline, smooth, up to $40 \mu \mathrm{m}$ long. Conidiogenous cells phialidic, cylindrical to elongate doliiform, hyaline, smooth, 6-18×1-3 $\mu \mathrm{m}(\bar{x}=11 \times 2 \mu \mathrm{m}, \mathrm{n}=20)$, with conspicuous collarettes and periclinal thickenings, covered by an olivaceous green mucoid layer. Conidia aseptate, smooth, hyaline, ellipsoidal, 5-8×3-4 $\mathrm{m}(\bar{x}=7 \times 3 \mu \mathrm{m}, \mathrm{n}=40)$.

Culture characteristics - Colonies on PDA attaining $30 \mathrm{~mm}$ diam. at $25^{\circ} \mathrm{C}$ after 7 days. White aerial mycelium and luteous to pale luteous mycelium; reverse yellow.

Material examined - ITALY, Province of Forlì-Cesena, San Lorenzo in Noceto - Forlì, on dead aerial branch of Vitis vinifera, 29 April 2014, Erio Camporesi IT 1838 (MFLU 15-0794, no culture is available), ITALY, Province of Forlì-Cesena, Trivella di Predappio, on dead aerial branch of $V$. vinifera, 8 March 2015, Erio Camporesi IT 2407 (MFLU 15-1084); living culture, MFLUCC 17-1233.

Notes - This genus was introduced to accommodate the leaf tip dieback and tuber rot pathogen of Cyperus esculentus. The two strains of this study clustered together with the type species A. cyperi-esculenti with high phylogenetic support. Crous et al. (2014) did not mention an asexual morph. Lin et al. (2017) introduced a new species of Alfaria based on phylogeny and asexual morphological characteristics and provided a backbone tree. This study provides the first report of A. cyperi-esculenti as a saprotroph on Vitis sp., as well as the first asexual morph description.

Alfaria vitis Manawasinghe, Camporesi \& K.D. Hyde, sp. nov.

Index Fungorum number: IF553955; Faces of fungi number: FoF03132

Etymology: Name reflects the host genus Vitis, from which the species was isolated

Holotype: MFLU 15-1082

Saprotrophic on dead branch of Vitis vinifera. Sexual morph: Not observed. Asexual morph: Conidiomata not observed, setae not observed, Conidiophores reduced to conidiogenous cells. Conidiogenous cells phialidic, clustered, hyaline or greenish pigmented, smooth-walled. Conidia aseptate, green to mouse grey to black masses, elongated $9-6 \mu \mathrm{m}(\bar{x}=7 \mu \mathrm{m}, \mathrm{n}=40)$ in length.

Culture characteristics - Colonies on PDA reach 3-5 cm diam. after 7 days at $25{ }^{\circ} \mathrm{C}$, upper side on PDA whitish circular, filiform margin, reverse on PDA yellowish, filiform.

Material examined - Italy, Province of Forlì-Cesena, near Pieve di Rivoschio, on dead aerial branch of Vitis vinifera, 2 February 2015, Erio Camporesi IT 2363, (MFLU 15-1082); ex-type living culture, MFLUCC 17-1055= KUMCC 17-0139.

Notes - The combined phylogenetic analysis of ITS, LSU and EF $\alpha$ placed Alfaria vitis within the genus Alfaria in Stachybotryaceae. It forms a sister taxon with A. putrifolia with 66\% bootstrap support and 0.95 Bayesian posterior probability values (Fig. 82). Compare to the sister 
taxon, this species does not produce setae and conidiophores are reduced to conidiogenous cells. On PDA, Alfaria putrifolia culture was sterile, but $A$. vitis produced conidia.
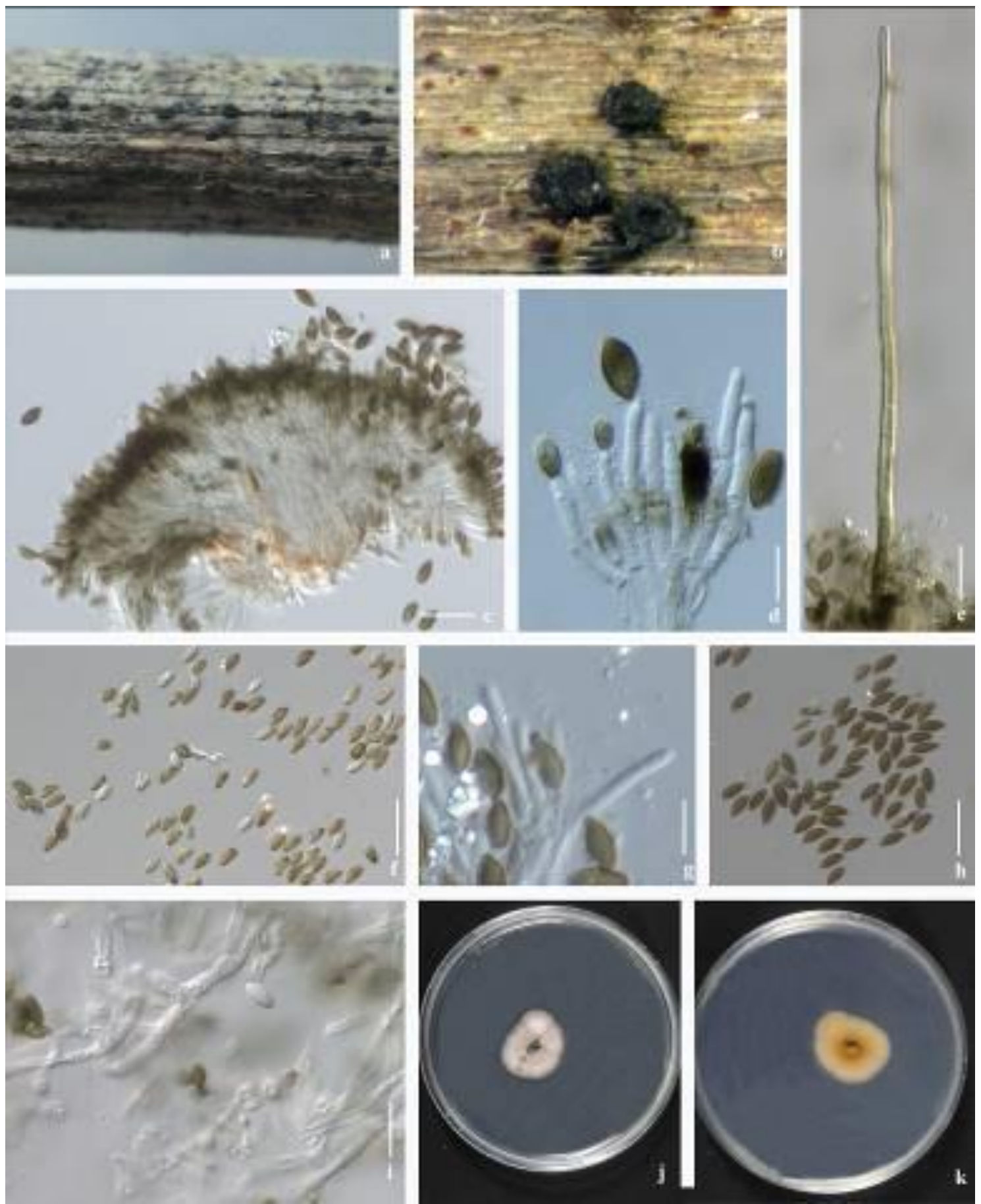

Fig. 78- Alfaria cyperi-esculenti. a, b. Conidiomata on host surface. c. Section of conidioma. d. Conidiophores and conidiogenous cells. e. Type II seta. f. Immature conidia. g. Type I setae. h. Mature conidia. i. Hyphae. j. Upper view of a 7 day old colony. k Reverse view of a 7 day old colony. Scale bars: $\mathrm{c}-\mathrm{i}=20 \mu \mathrm{m}$.

\section{Xylariales genera incertae sedis}

Neoanthostomella D.Q. Dai \& K.D. Hyde, in Dai, Phookamsak, Wijayawardene, Li, Bhat, Xu, Taylor, Hyde \& Chukeatirote, Fungal Diversity: 10.1007/s13225-016-0367-8, [84] (2016) 
Neoanthostomella was introduced by Dai et al. (2016) to accommodate $N$. pseudostromatica. There are only two species in the genus (Index Fungorum 2018). A phylogenetic tree for Xylariaceae is given in Fig. 82.
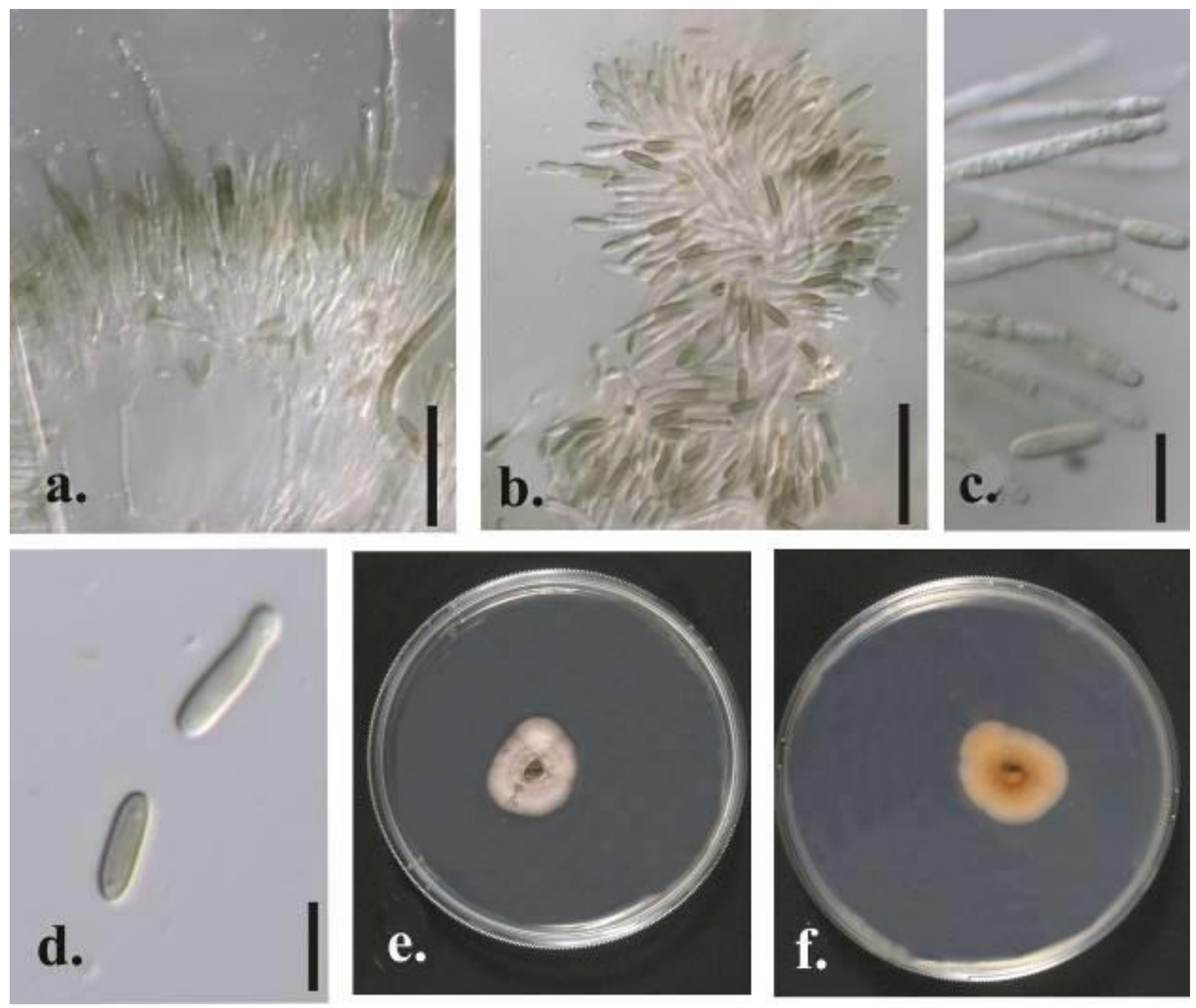

Fig. 79 - Alfaria vitis. a-b. Penicillate conidiophores. c. Conidiogenous cells d. Conidia. Scale bars: $\mathrm{a}-\mathrm{b}=20 \mu \mathrm{m}, \mathrm{c}-\mathrm{d}=10 \mu \mathrm{m}$.

Neoanthostomella viticola Daranagama, Camporesi \& K. D. Hyde, in Daranagama, Camporesi, Jeewon, Liu, Stadler, Lumyong \& Hyde, Cryptog. Mycol. 37(4): 524 (2016)

Facesoffungi number: FoF03817

Saprotrophic on dead branch of Vitis vinifera. Sexual morph: Ascomata 160-203×180-225 $\mu \mathrm{m}(\bar{x}=186 \mu \mathrm{m} \times 205 \mu \mathrm{m}, \mathrm{n}=10)$, immersed, visible as black, raised, conical-irregular shaped areas, coriaceous, clustered, rarely solitary, scattered, in cross section globose, with wide ostiolar neck. Ostiole 82-110 $\mu \mathrm{m}$ diam. at the base, $50-66 \mu \mathrm{m}$ high $(\bar{x}=102 \times 64 \mu \mathrm{m}, \mathrm{n}=10)$, grey, papillate, with a central periphysate ostiolar canal. Peridium $34-53 \mu \mathrm{m}$ wide $(\bar{x}=41 \mu \mathrm{m}, \mathrm{n}=10)$, with two cell layers, outwardly comprising thick-walled, compressed, light brown cells of textura irregularis and inwardly comprising thick-walled, several layers of hyaline cells of textura angularis. Paraphyses 3-3.4 $\mu \mathrm{m}$ wide at base $(\bar{x}=3 \mu \mathrm{m}, \mathrm{n}=30)$, slightly longer than the asci, numerous, filamentous, septate. Asci $85-117 \times 5-7 \mu \mathrm{m}(\bar{x}=92 \times 7 \mu \mathrm{m}, \mathrm{n}=20)$, 8-spored, unitunicate, cylindrical, long pedicellate, with apical apparatus. Ascospores $6-11 \times 3-5 \mu \mathrm{m}(\bar{x}=9 \times 4 \mu \mathrm{m}, \mathrm{n}=20)$, uniseriateoverlapping uniseriate, ellipsoidal, with pointed ends, light brown, smooth-walled, germ slit spiral, $2 / 3$ of the full-length. Asexual morph: Hyphomycetous. Conidiophores $60-80 \times 5-8 \mu \mathrm{m}(\bar{x}=76 \times 6$ $\mu \mathrm{m}, \mathrm{n}=40$ ), macronematous, septate, densely branched in the upper part, hyaline, smooth. Conidiogenous cells $9-12 \times 3-6 \mu \mathrm{m}(\bar{x}=11 \times 5 \mu \mathrm{m}, \mathrm{n}=40)$, phialidic, with an apical collarette, 
cylindrical, slightly wider at base, hyaline, smooth. Conidia 5-8 $\times 4-6 \mu \mathrm{m}(\bar{x}=7 \times 4 \mu \mathrm{m}, \mathrm{n}=20)$, hyaline, globose to ellipsoidal, slightly verruculose.

Culture characteristics - Colonies on Difco OA at $25-27{ }^{\circ} \mathrm{C}$ reaching $9 \mathrm{~cm}$ diam in 6 weeks, at first whitish, felty, azonate, with fluffy margins; reverse turning citrine light yellow after 2-3 weeks.

Material examined - ITALY, Province of Forlì-Cesena, Trivella di Predappio, on dead aerial branch of Vitis vinifera, 31 December 2014, Erio Camporesi, IT 2326 (MFLU 15-0691), cultures MFLUCC 16-0243, KUMCC 17-0102, MFLUCC 15-0517, MFLUCC 15-0518.

Notes - Neoanthostomella viticola was introduced by Daranagama et al. (2016) to accommodate a species isolated from Vitis vinifera in Italy.

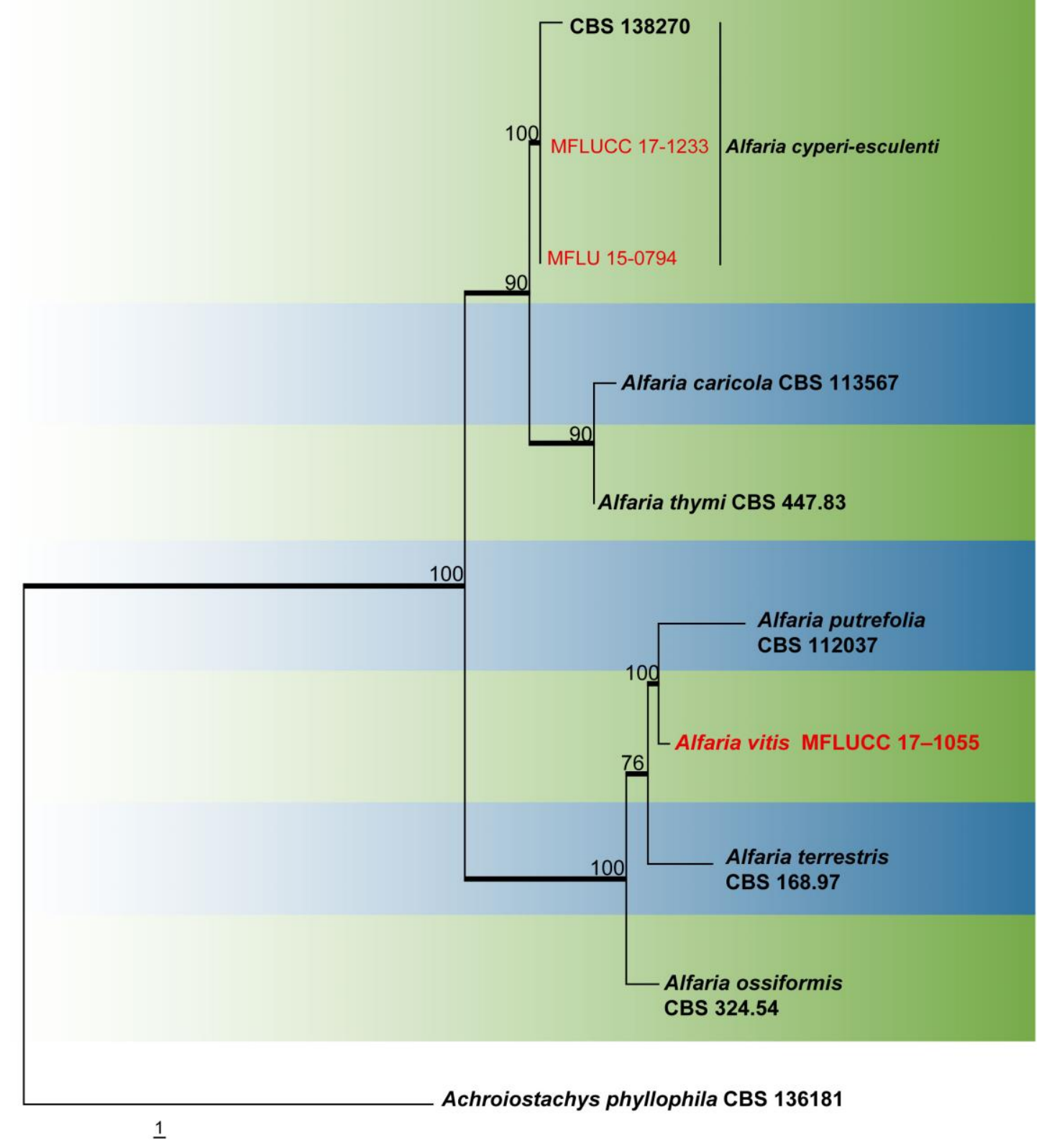

Fig. 80 - One of ten most parsimonious trees obtained from a heuristic search of combined ITS and LSU sequence data of taxa from Alfaria. Parsimony bootstrap support values above $50 \%$ are indicated at the nodes and branches with Bayesian posterior probabilities above 0.75 given in bold. Ex-type strains are in bold. Strains obtained in this study are in red. The tree is rooted with Achroiostachys phyllophila CBS 136181. 

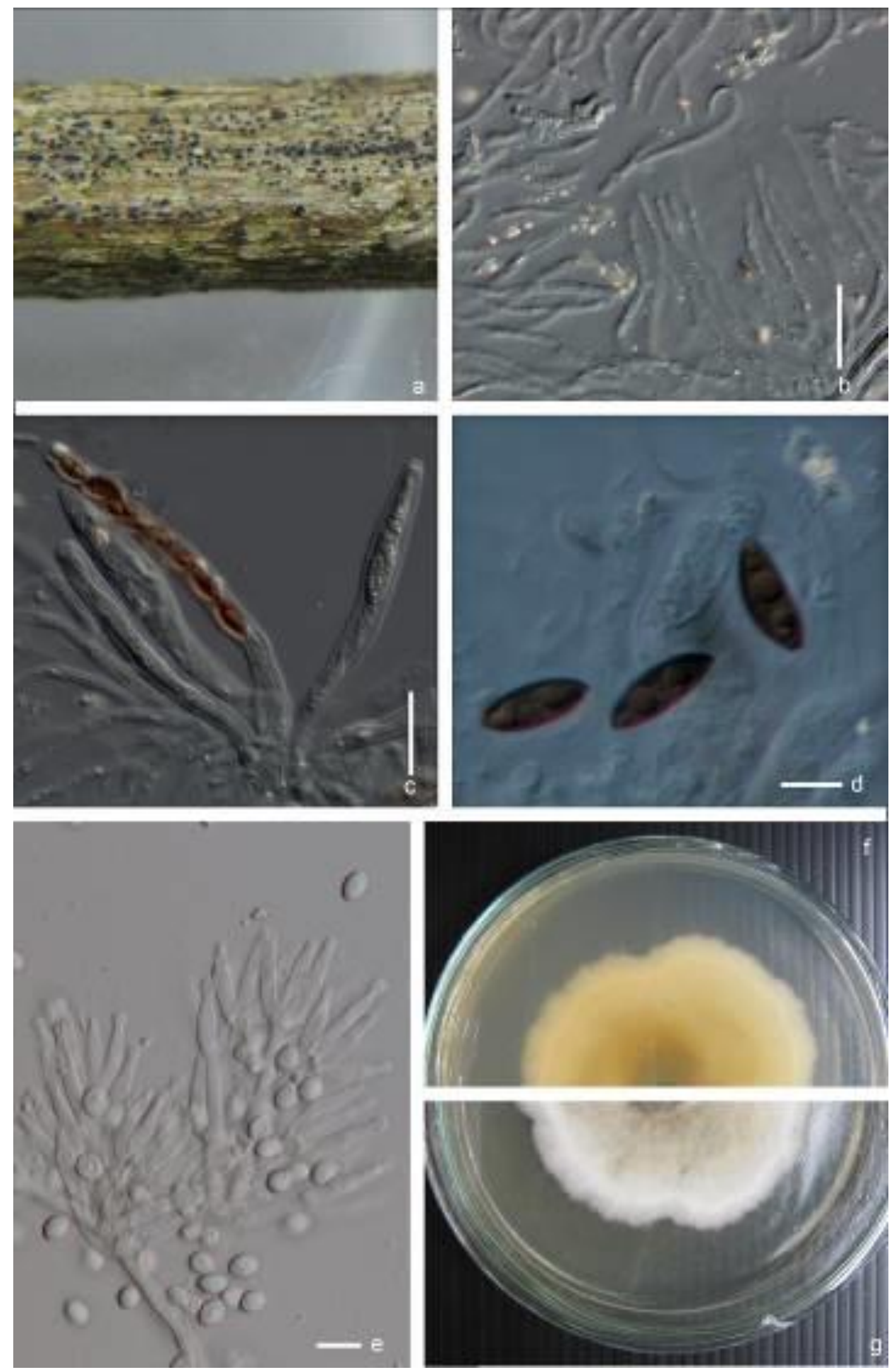

Fig. 81 - Neoanthostomella viticola. a. Fruiting bodies on host tissue. b. Paraphyses. c. Immature and mature asci. d. Ascospores. e. Conidiophores, conidiogenous cells and conidia f. Reverse view of colony on OA g. Upper view of the colony on OA. Scale bars: $b-g=10 \mu \mathrm{m}$. 


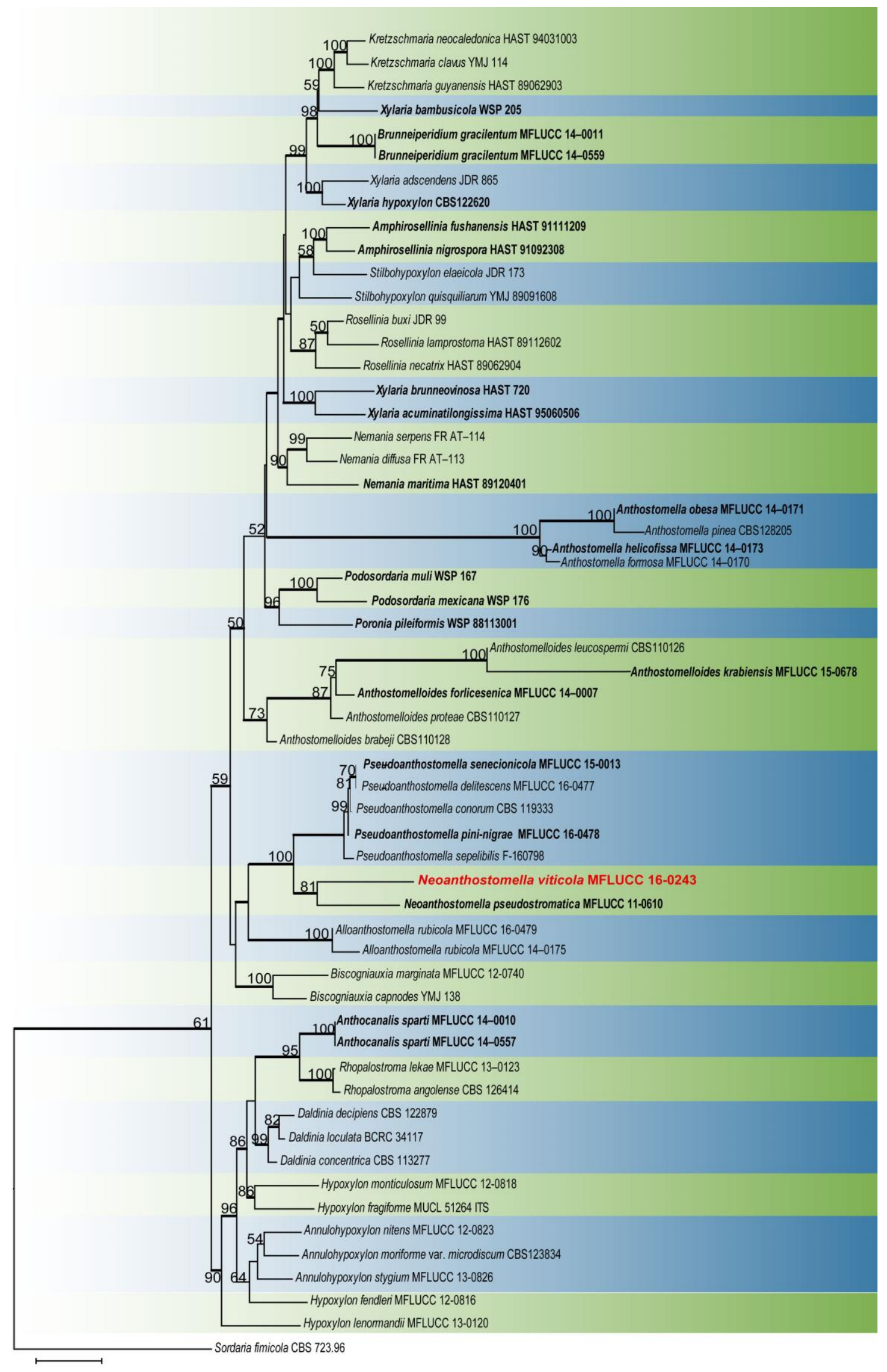

Fig. 82 - RAxML phylogram obtained from combined ITS, LSU, RPB2, TUB2 sequence data of Xylariaceae. Ex-type strains are in bold. Strains isolated in this study are shown in red. RAxML bootstrap support (BS) values $\geq 50 \%$ are shown at the nodes and branches with Bayesian posterior probability scores $\geq 0.90$ are given in bold. The tree is rooted with Sordaria fimicola. 


\section{Leotiomycetes}

Helotiales Nannf. ex Korf \& Lizoň, Mycotaxon 75: 501 (2000)

Sclerotiniaceae Whetzel, Mycologia 37(6): 652 (1945)

Botrytis cinerea Pers., Syn. meth. fung. (Göttingen) 2: 690 (1801)

Facesoffungi number: FoF:03822

Notes - This species is a well-known pathogen, endophyte and a saprotroph on Vitis vinifera. Phylogenetic analysis including the strains isolated in this study is given in Fig. 83.

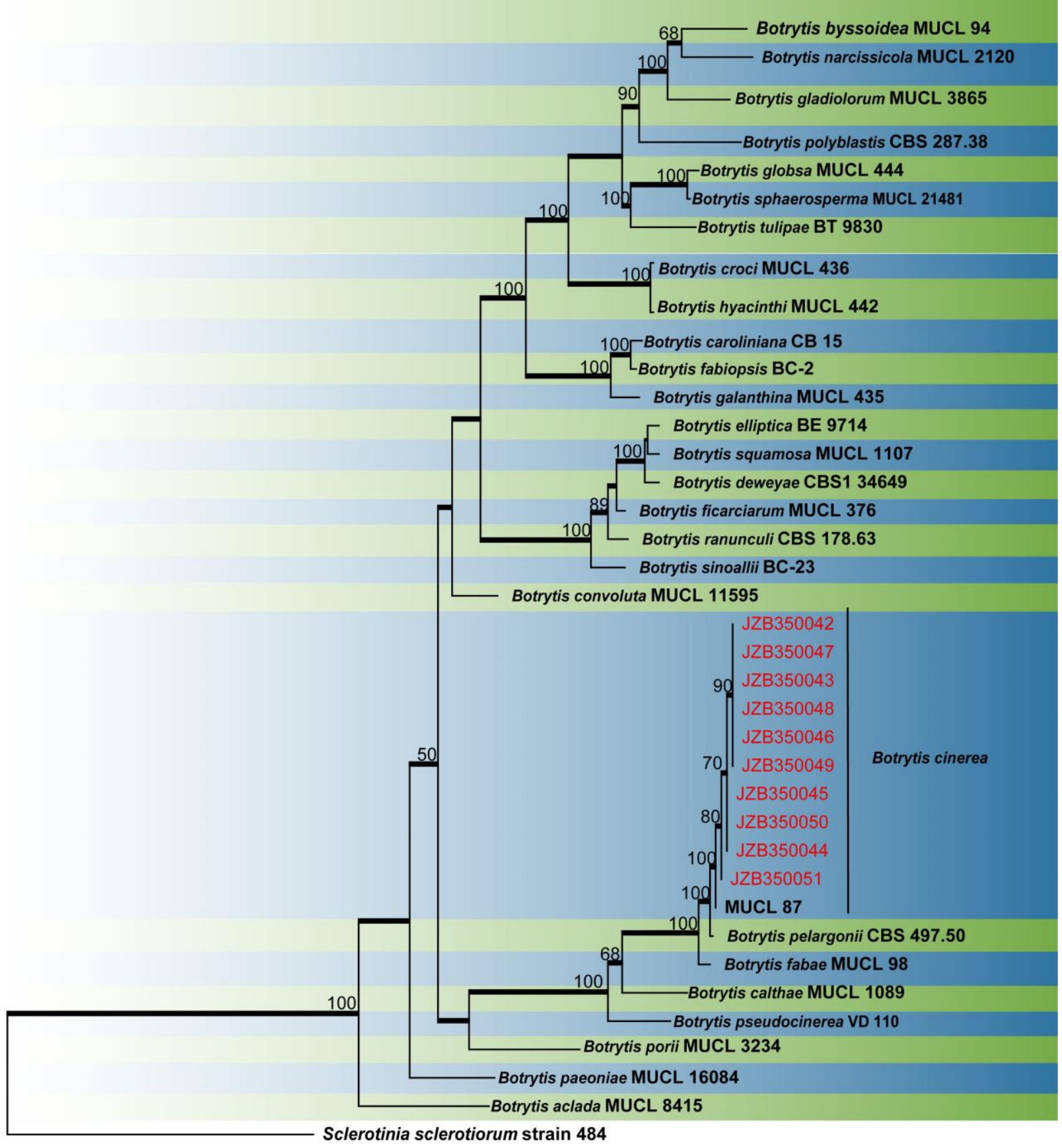

10

Fig. 83 - One of ten most parsimonious trees obtained from a heuristic search of combined G3PDH, HSP60 and RPB2 sequence data of taxa from Botrytis. Parsimony bootstrap support values above $50 \%$ are indicated at the nodes and branches with Bayesian posterior probabilities above 0.75 given in bold. Ex-type strains are in bold. Strains obtained in this study are in red. The tree is rooted with Sclerotinia sclerotiorum strain 484. 


\section{Mucoromycetes}

Mucorales Fr., Syst. mycol. (Lundae) 3(2): 296 (1832)

Mucoraceae Dumort., Comment. bot. (Tournay): 69 (1822)

Species of this family are mainly saprotrophs inhabiting soil, dung and dead plant material, although several are parasites on plants and on other fungi (Walther et al. 2013).

Actinomucor Schostak., Ber. dt. bot. Ges. 16: 155 (1898)

This genus is closely related to Mucor, but differs in having branched stolons which give rise to rhizoids and sporangiophores (Karimi et al. 2015). Strains from our study appeared to be $A$. elegans.

Actinomucor elegans (Eidam) C.R. Benj. \& Hesselt., Mycologia 49: 241 (1957)

See Karimi et al. (2015) for the description.

Notes - Actinomucor elegans is recorded as a saprotroph on Vitis vinifera from China for the first time.

Mucor racemosus Bull., Hist. Champ. Fr. (Paris) 1: 104, tab. 504, fig. VII (1791)

Notes - Mucor racemosus has been recorded as an endophyte from Spain and Switzerland from Vitis vinifera (Casieri et al. 2009; Gonzalez \& Tello 2011). This study provides the first report of this species as a saprotroph on $V$. vinifera from China. This species can be a secondary invader causing bunch rot of grapevine.

Mucor circinelloides Tiegh., Annls Sci. Nat., Bot., sér. 6 1: 94 (1875)

Notes - There is only one record of this species from Vitis vinifera. Mucor circinelloides has been recorded as a saprotroph from Switzerland (Casieri et al. 2009). This study provides the first report of this species as a saprotroph on $V$. vinifera from China.

Rhizopodaceae K. Schum., Lehrb. system. Bot. Phytopaläont. Phytogeogr. (Stuttgart): 70 (1894)

Rhizopus oryzae Went \& Prins. Geerl., Verh. K. Akad. Wet., tweede sect. 4(2): 16 (1895)

Notes - This study provides the first record of $R$. oryzae associated with $V$. vinifera.

\section{Eurotiomycetes}

Eurotiales G.W. Martin ex Benny \& Kimbr., Mycotaxon 12(1): 23 (1980)

Trichocomaceae E. Fisch., in Engler \& Prantl, Nat. Pflanzenfam., Teil. I (Leipzig) 1: 310 (1897)

Aspergillus aculeatus Iizuka, J. agric. Chem. Soc. Japan 27: 806 (1953)

Notes - Aspergillus aculeatus is known to cause bunch rot of grapes in Canada (Jarvis \& Traquair 1984). However, this species is considered as a secondary invader. Aspergillus aculeatus is recorded for the first time in China on $V$. vinifera as a saprotroph. A phylogenetic analysis of the strains isolated in this study is given in Fig. 84.

Aspergillus niger Tiegh., Annls Sci. Nat., Bot., sér. 5 8: 240 (1867)

Notes - This species is known to be associated with cankers as well as bunch rot of grapevine in grape growing regions (Gonzalez \& Tello 2011). Aspergillus niger has been also recorded as a saprotroph and endophyte of $V$. vinifera.

Penicillium brevicompactum Dierckx, Ann. Soc. Sci. Bruxelles 25: 88 (1901)

Notes - This study provides the first record of $P$. brevicompactum associated with $V$. vinifera. 


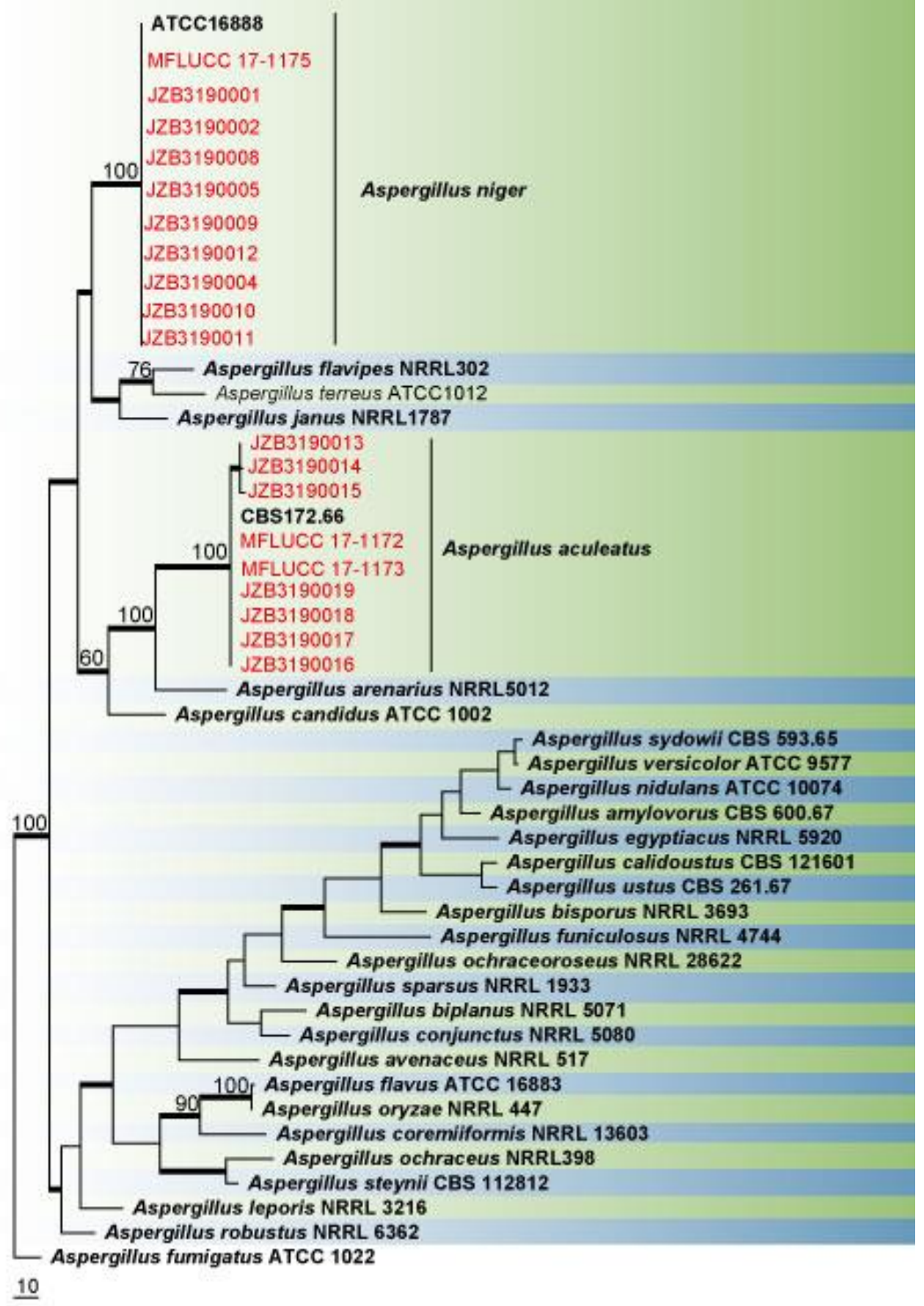

Fig. 84 - One of ten most parsimonious trees obtained from a heuristic search for ITS sequence data of taxa from Aspergillus. Parsimony bootstrap support values above $50 \%$ are indicated at the nodes and branches with Bayesian posterior probabilities above 0.75 given in bold. Ex-type strains are in bold. Strains obtained in this study are in red. The tree is rooted with Aspergillus fumigatus ATCC 1022

Penicillium citrinum Thom, Bull. U.S. Department of Agriculture, Bureau Animal Industry 118: 61 (1910)

Notes - This study provides the first record of $P$. citrinum associated with $V$. vinifera.

Penicillium terrigenum Houbraken, Frisvad \& Samson, Stud. Mycol. 70: 125 (2011) 
Notes - Penicillium terrigenum was first described from soil. This study provides the first record of $P$. terrigenum associated with $V$. vinifera.

Talaromyces amestolkiae N. Yilmaz, Houbraken, Frisvad \& Samson, in Yilmaz, Houbraken, Hoekstra, Frisvad, Visagie \& Samson, Persoonia 29: 48 (2012)

Notes - Talaromyces amestolkiae was described from house dust in South Africa (Yilmaz et al. 2012). This study provides the first record of $T$. amestolkiae associated with $V$. vinifera.

Talaromyces pinophilus (Hedgc.) Samson, N. Yilmaz, Frisvad \& Seifert, in Samson, Yilmaz, Houbraken, Spierenburg, Seifert, Peterson, Varga \& Frisvad, Stud. Mycol. 70: 176 (2011) vinifera.

Notes - Talaromyces pinophilus is recorded for the first time as a saprotroph from Vitis

Talaromyces purpureogenus Samson, N. Yilmaz, Houbraken, Spierenb., Seifert, Peterson, Varga \& Frisvad, in Samson, Yilmaz, Houbraken, Spierenburg, Seifert, Peterson, Varga \& Frisvad, Stud. Mycol. 70: 177 (2011)

Notes - This study provides the first record of T. purpureogenus as a saprotroph on $V$. vinifera from China.

Agaricomycetes Doweld

Cantharellales Incertae sedis

\section{Minimedusa sp.}

Notes - This study provides the first report of Minimedusa sp. as a saprotroph associated with Vitis vinifera in China as well as in the world.

Peniophoraceae Lotsy, Vortr. bot. Stammesgesch. 1: 687 (1907)

\section{Peniophora sp.}

Notes - Peniophora albomarginata and P. viticola have been recorded as saprotrophs on Vitis vinifera in USA (Jayawardena et al. 2018). This study provides the first record of a Peniophora sp. associated with $V$. vinifera in China.

\section{Oomycota Incertae sedis}

Peronosporales E. Fisch., Rabenh. Krypt.-Fl., Edn 2 (Leipzig) 1(4): 383 (1892)

Pythiaceae J. Schröt., Nat. Pflanzenfam. (Leipzig) 1(1): 104 (1893)

Pythium amasculinum Y.N. Yu, Acta microbiol. sin. 13(2): 118 (1973)

Notes - Species of Pythium are known to cause root rot of $V$. vinifera (Jayawardena et al. 2018). This study provides the first report of $P$. amasculinum as a saprotroph associated with $V$. vinifera in China.

\section{Discussion}

Numerous fungal species occur on Vitis species worldwide. In this study, we show the diversity and taxonomy of 67 fungal species associated with Vitis species, with molecular data and descriptions linked to morphological illustrations when possible. We hope that this research will stimulate interest in the collection and description of fungi associated with Vitis species other than pathogens. There are more than 500 fungal species recorded on Vitis spp. in the checklist provided by Jayawardena et al. (2018) and are likely to be thousands of species that are associated with Vitis species worldwide. Many of the saprotrophs are also well-known pathogens and they may be the primary source of inoculant in a vineyard. These taxa need to be collected, and where necessary epitypified and sequenced in order to have a better understanding about the host genus Vitis. 


\begin{tabular}{|c|c|c|c|c|c|c|c|c|c|c|c|c|c|}
\hline Species Name & Isolate No & ITS & LSU & SSU & RPB2 & TUB2 & TEF & CAL & ACT & CHS & GAPDH & Histone & HSP60 \\
\hline Albifimbria verrucaria & $\begin{array}{l}\text { MFLUCC } \\
17-2381\end{array}$ & MG764005 & MG792336 & & & & & & & & & & \\
\hline Albifimbria viridis & $\begin{array}{l}\text { MFLUCC } \\
17-1149\end{array}$ & MG764006 & MG792337 & & & & & & & & & & \\
\hline \multirow[t]{2}{*}{ Alfaria cyperi-esculenti } & $\begin{array}{l}\text { MFLU 15- } \\
0794\end{array}$ & MG763956 & MG812526 & & & & & & & & & & \\
\hline & $\begin{array}{l}\text { MFLUCC } \\
17-1233\end{array}$ & MG763957 & MG812527 & & & & & & & & & & \\
\hline Alfaria vitis & $\begin{array}{l}\text { MFLUCC } \\
17-1055\end{array}$ & KY649631 & & & & & KY926886 & & & & & & \\
\hline \multirow[t]{9}{*}{ Alternaria alternata } & $\begin{array}{l}\text { KUMCC 17- } \\
0118\end{array}$ & MG764010 & & & & & MG818319 & & & & & & \\
\hline & $\begin{array}{l}\text { MFLUCC } \\
17-1218\end{array}$ & MG764015 & MG818322 & & MG859740 & & MG818320 & & & & MG859751 & & \\
\hline & $\begin{array}{l}\text { MFLUCC } \\
17-1222\end{array}$ & MG764022 & MG818326 & & MG859744 & & MG818321 & & & & MG859755 & & \\
\hline & $\begin{array}{l}\text { MFLUCC } \\
17-1229\end{array}$ & MG764019 & MG818323 & & MG859741 & & MG818322 & & & & MG859752 & & \\
\hline & $\begin{array}{l}\text { MFLUCC } \\
17-1230\end{array}$ & MG764014 & MG818327 & & MG859745 & & MG818323 & & & & MG859756 & & \\
\hline & $\begin{array}{l}\text { MFLUCC } \\
17-1241\end{array}$ & MG764013 & & & & & MG818324 & & & & & & \\
\hline & $\begin{array}{l}\text { MFLUCC } \\
17-1250\end{array}$ & MG764012 & MG818324 & & MG859742 & & MG818325 & & & & MG859753 & & \\
\hline & $\begin{array}{l}\text { MFLUCC } \\
17-1251\end{array}$ & MG764011 & MG818325 & & MG859743 & & MG818326 & & & & MG859754 & & \\
\hline & $\begin{array}{l}\text { MFLUCC } \\
17-1187\end{array}$ & MG764009 & MG818320 & & MG859739 & & MG818327 & & & & MG859750 & & \\
\hline \multirow[t]{2}{*}{ Alternaria italica } & $\begin{array}{l}\text { MFLUCC } \\
14-0421\end{array}$ & MG764018 & & & MG859737 & & & & & & & & \\
\hline & $\begin{array}{l}\text { KUMCC 17- } \\
0090\end{array}$ & MG764019 & & & & & & & & & & & \\
\hline \multirow[t]{2}{*}{ Alternaria vitis } & $\begin{array}{l}\text { MFLUCC } \\
17-1109\end{array}$ & MG764007 & MG818319 & & & & & & & & & & \\
\hline & $\begin{array}{l}\text { MFLUCC } \\
17-1116\end{array}$ & MG764008 & & & & & & & & & & & \\
\hline \multirow[t]{2}{*}{ Angustimassarina populi } & $\begin{array}{l}\text { MFLUCC } \\
17-1069\end{array}$ & MF409170 & MF409166 & MF409165 & & & MF409163 & & & & & & \\
\hline & $\begin{array}{l}\text { MFLUCC } \\
17-1217\end{array}$ & MG763958 & MG812609 & MG812610 & & & MG812528 & & & & & & \\
\hline \multirow[t]{8}{*}{ Aspergillus aculeatus } & JZB3190013 & MG764030 & & & & & & & & & & & \\
\hline & JZB3190014 & MG764031 & & & & & & & & & & & \\
\hline & JZB3190015 & MG764032 & & & & & & & & & & & \\
\hline & $\begin{array}{l}\text { MFLUCC } \\
17-1172\end{array}$ & MG764033 & & & & & & & & & & & \\
\hline & $\begin{array}{l}\text { MFLUCC } \\
17-1173\end{array}$ & MG764034 & & & & & & & & & & & \\
\hline & JZB3190016 & MG764038 & & & & & & & & & & & \\
\hline & JZB3190017 & MG764037 & & & & & & & & & & & \\
\hline & JZB3190018 & MG764036 & & & & & & & & & & & \\
\hline
\end{tabular}

Submitted 30 November 2017, Accepted 29 January 2018, Published online 5 February 2018

Corresponding Authors: JY Yan - e-mail - jiyeyan@vip.163.com and RS Jayawardena - e-mail - ruvi.jaya@yahoo.com 


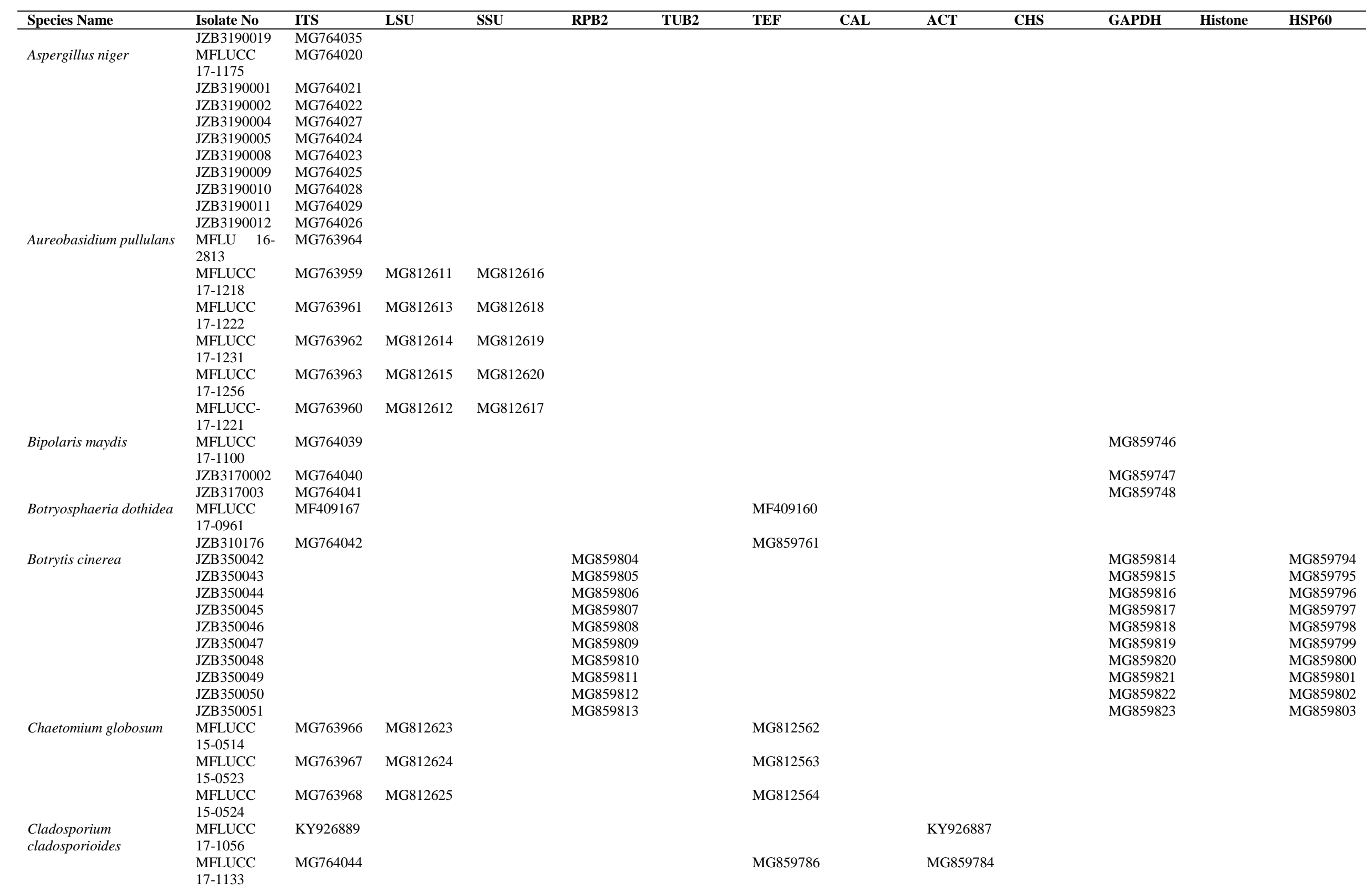




\begin{tabular}{|c|c|c|c|c|c|c|c|c|c|c|c|c|c|}
\hline Species Name & Isolate No & ITS & LSU & SSU & RPB2 & TUB2 & TEF & CAL & ACT & CHS & GAPDH & Histone & HSP60 \\
\hline & MFLUCC & MG764043 & & & & & & & MG859785 & & & & \\
\hline $\begin{array}{l}\text { Cladosporium } \\
\text { cucumerinum }\end{array}$ & $\begin{array}{l}17-1182 \\
\text { MFLU } \\
0206\end{array}$ & MG764045 & & & & & & & & & & & \\
\hline \multirow[t]{3}{*}{$\begin{array}{l}\text { Colletotrichum } \\
\text { dematium }\end{array}$} & $\begin{array}{l}\text { MFLUCC } \\
17-1092\end{array}$ & MG763969 & & & & MG812538 & & & MG812529 & MG812532 & MG812535 & & \\
\hline & $\begin{array}{l}\text { MFLUCC } \\
17-1096\end{array}$ & MG763970 & & & & MG812539 & & & MG812530 & MG812533 & MG812536 & & \\
\hline & $\begin{array}{l}\text { MFLUCC } \\
17-1097\end{array}$ & MG763971 & & & & MG812540 & & & MG812531 & MG812534 & MG812537 & & \\
\hline \multirow[t]{2}{*}{ Colletotrichum godetiae } & $\begin{array}{l}\text { MFLUCC } \\
17-1062\end{array}$ & KY632679 & & & & KY632673 & & & KY632671 & KY632675 & KY632677 & & \\
\hline & $\begin{array}{l}\text { MFLUCC } \\
17-1395\end{array}$ & KY632680 & & & & KY632674 & & & KY632672 & KY632676 & KY632678 & & \\
\hline $\begin{array}{l}\text { Colletotrichum } \\
\text { hebeiense }\end{array}$ & JZB330117 & MG763977 & & & & MG812546 & & & MG812561 & MG812549 & MG812555 & & \\
\hline Colletotrichum siamense & $\begin{array}{l}\text { MFLUCC } \\
17-1219\end{array}$ & MG763974 & & & & MG812543 & & & MG812558 & & MG812552 & & \\
\hline $\begin{array}{l}\text { Colletotrichum } \\
\text { truncatum }\end{array}$ & $\begin{array}{l}\text { MFLUCC } \\
17-2380\end{array}$ & MG764046 & & & & MG859758 & & & MG859760 & MG8597559 & MG859757 & & \\
\hline \multirow[t]{4}{*}{ Colletotrichum viniferum } & $\begin{array}{l}\text { MFLUCC } \\
14-1213\end{array}$ & MG763972 & & & & MG812541 & & & MG812556 & MG812547 & MG812550 & & \\
\hline & $\begin{array}{l}\text { MFLUCC } \\
14-1214\end{array}$ & MG763973 & & & & MG812542 & & & MG812557 & MG812548 & MG812551 & & \\
\hline & JZB330118 & MG763976 & & & & MG812545 & & & MG812560 & & MG812554 & & \\
\hline & JZB330119 & MG763975 & & & & MG812544 & & & MG812559 & & MG812553 & & \\
\hline \multirow{7}{*}{ Coniella vitis } & JZB3700009 & MG764053 & MG837140 & & & & MG859783 & & & & & MG859793 & \\
\hline & JZB3700014 & MG764051 & MG837138 & & & & MG859781 & & & & & MG859791 & \\
\hline & JZB3700026 & MG764052 & MG837139 & & & & MG859782 & & & & & MG859792 & \\
\hline & $\begin{array}{l}\text { MFLUCC } \\
1125\end{array}$ & MG764049 & MG837136 & & & & MG859779 & & & & & MG859789 & \\
\hline & $\begin{array}{l}\text { MFLUCC } \\
17-1113\end{array}$ & MG764047 & MG837134 & & & & MG859777 & & & & & MG859787 & \\
\hline & $\begin{array}{l}\text { MFLUCC } \\
17-1123\end{array}$ & MG764048 & MG837137 & & & & MG859780 & & & & & MG859790 & \\
\hline & $\begin{array}{l}\text { MFLUCC } \\
17-1138\end{array}$ & MG764050 & MG837135 & & & & MG859778 & & & & & MG859788 & \\
\hline Cryptovalsa ampelina & $\begin{array}{l}\text { MFLUCC } \\
15-0139 \\
\text { MFLUC 16- } \\
007\end{array}$ & KU550094 & KU550096 & KU550095 & & & & & & & & & \\
\hline \multirow[t]{3}{*}{ Diaporthe ampelina } & $\begin{array}{l}\text { MFLUCC } \\
16-0960\end{array}$ & MF409171 & & & & MF409159 & MF409164 & MF409172 & & & & & \\
\hline & $\begin{array}{l}\text { MFLUCC } \\
17-1270\end{array}$ & MG763978 & & & & MG812588 & MG812565 & MG812586 & & & & & \\
\hline & $\begin{array}{l}\text { MFLUCC } \\
17-1271\end{array}$ & MG763979 & & & & MG812589 & MG812566 & MG812587 & & & & & \\
\hline \multirow[t]{2}{*}{ Diaporthe eres } & MFLUCC & MG763981 & & & & & MG812568 & & & & & & \\
\hline & $\begin{array}{l}\text { MFLUCC } \\
17-1106\end{array}$ & MG763982 & & & & MG812591 & MG812569 & MG812583 & & & & & \\
\hline
\end{tabular}




\begin{tabular}{|c|c|c|c|c|c|c|c|c|c|c|c|c|c|}
\hline Species Name & Isolate No & ITS & LSU & SSU & RPB2 & TUB2 & TEF & CAL & ACT & CHS & GAPDH & Histone & HSP60 \\
\hline & $\begin{array}{l}\text { MFLUCC } \\
17-1160\end{array}$ & MG763980 & & & & MG812590 & MG812567 & MG812582 & & & & & \\
\hline & JZB320118 & MG763983 & & & & MG812592 & MG812570 & MG812584 & & & & & \\
\hline & JZB320119 & MG763984 & & & & MG812593 & MG812571 & MG812585 & & & & & \\
\hline Diaporthe rudis & $\begin{array}{l}\text { MFLU 17- } \\
2818\end{array}$ & MG763985 & & & & MG812594 & MG812572 & & & & & & \\
\hline \multirow[t]{2}{*}{ Didymella negeriana } & $\begin{array}{l}\text { MFLUCC } \\
16-1394\end{array}$ & KY632665 & KY632667 & & KY632669 & KY632663 & & & & & & & \\
\hline & $\begin{array}{l}\text { MFLUCC } \\
17-1061\end{array}$ & KY632666 & KY632668 & & KY632670 & KY632664 & & & & & & & \\
\hline \multirow[t]{3}{*}{ Didymella pomorum } & $\begin{array}{l}\text { MFLUCC } \\
17-1112\end{array}$ & MG763986 & MG812603 & & MG812606 & MG812595 & & & & & & & \\
\hline & $\begin{array}{l}\text { MFLUCC } \\
17-1121\end{array}$ & MG763987 & MG812604 & & MG812607 & MG812596 & & & & & & & \\
\hline & $\begin{array}{l}\text { MFLUCC } \\
17-1158\end{array}$ & MG763988 & MG812605 & & MG812608 & MG812597 & & & & & & & \\
\hline \multirow[t]{5}{*}{ Diplodia seriata } & $\begin{array}{l}\text { MFLUCC } \\
17-1251\end{array}$ & MG763989 & & & & & MG812577 & & & & & & \\
\hline & $\begin{array}{l}\text { MFLUCC } \\
17-1252\end{array}$ & MG763990 & & & & & MG812578 & & & & & & \\
\hline & $\begin{array}{l}\text { MFLUCC } \\
17-1253\end{array}$ & MG763991 & & & & & MG812579 & & & & & & \\
\hline & $\begin{array}{l}\text { MFLUCC } \\
17-1264\end{array}$ & MG763992 & & & & & MG812580 & & & & & & \\
\hline & $\begin{array}{l}\text { MFLUCC } \\
17-1265\end{array}$ & MG763993 & & & & & MG812581 & & & & & & \\
\hline Dothiorella iberica & $\begin{array}{l}\text { MFLUCC } \\
\text { 17-0964 }\end{array}$ & MF409168 & & & & & MF409161 & & & & & & \\
\hline \multirow[t]{4}{*}{$\begin{array}{l}\text { Dothiorella } \\
\text { sarmentorum }\end{array}$} & $\begin{array}{l}\text { MFLUCC } \\
\text { 17-0962 }\end{array}$ & MF409169 & & & & & MF409162 & & & & & & \\
\hline & $\begin{array}{l}\text { MFLUCC } \\
17-1212\end{array}$ & MG763994 & & & & & MG812573 & & & & & & \\
\hline & $\begin{array}{l}\text { MFLUCC } \\
17-1213\end{array}$ & MG763995 & & & & & MG812574 & & & & & & \\
\hline & JZB3150039 & MG763996 & & & & & MG812576 & & & & & & \\
\hline \multirow[t]{9}{*}{ Epicoccum nigrum } & $\begin{array}{l}\text { KUMCC 17- } \\
0092\end{array}$ & MG807025 & MG818842 & & MG859837 & MG859828 & & & & & & & \\
\hline & $\begin{array}{l}\text { MFLUCC } \\
17-1214\end{array}$ & MG807027 & MG818843 & & MG859839 & MG859830 & & & & & & & \\
\hline & $\begin{array}{l}\text { MFLUCC } \\
17-1215\end{array}$ & MG807026 & MG818844 & & MG859838 & MG859829 & & & & & & & \\
\hline & JZB380010 & MG807022 & MG818845 & & MG859835 & MG859826 & & & & & & & \\
\hline & JZB380011 & MG807024 & MG818846 & & MG859836 & MG859827 & & & & & & & \\
\hline & $\begin{array}{l}\text { MFLUCC } \\
17-1153\end{array}$ & MG807028 & MG818847 & & MG859840 & MG859831 & & & & & & & \\
\hline & JZB380012 & MG807023 & MG818848 & & MG859834 & MG859825 & & & & & & & \\
\hline & JZB380013 & MG807021 & MG818849 & & MG859833 & MG859824 & & & & & & & \\
\hline & $\begin{array}{l}\text { MFLUCC } \\
17-1162\end{array}$ & MG807029 & MG818850 & & MG859841 & MG859832 & & & & & & & \\
\hline Floricola viticola & $\begin{array}{l}\text { MFLUCC } \\
15-0039\end{array}$ & & MG837003 & MG8370034 & & & & & & & & & \\
\hline
\end{tabular}




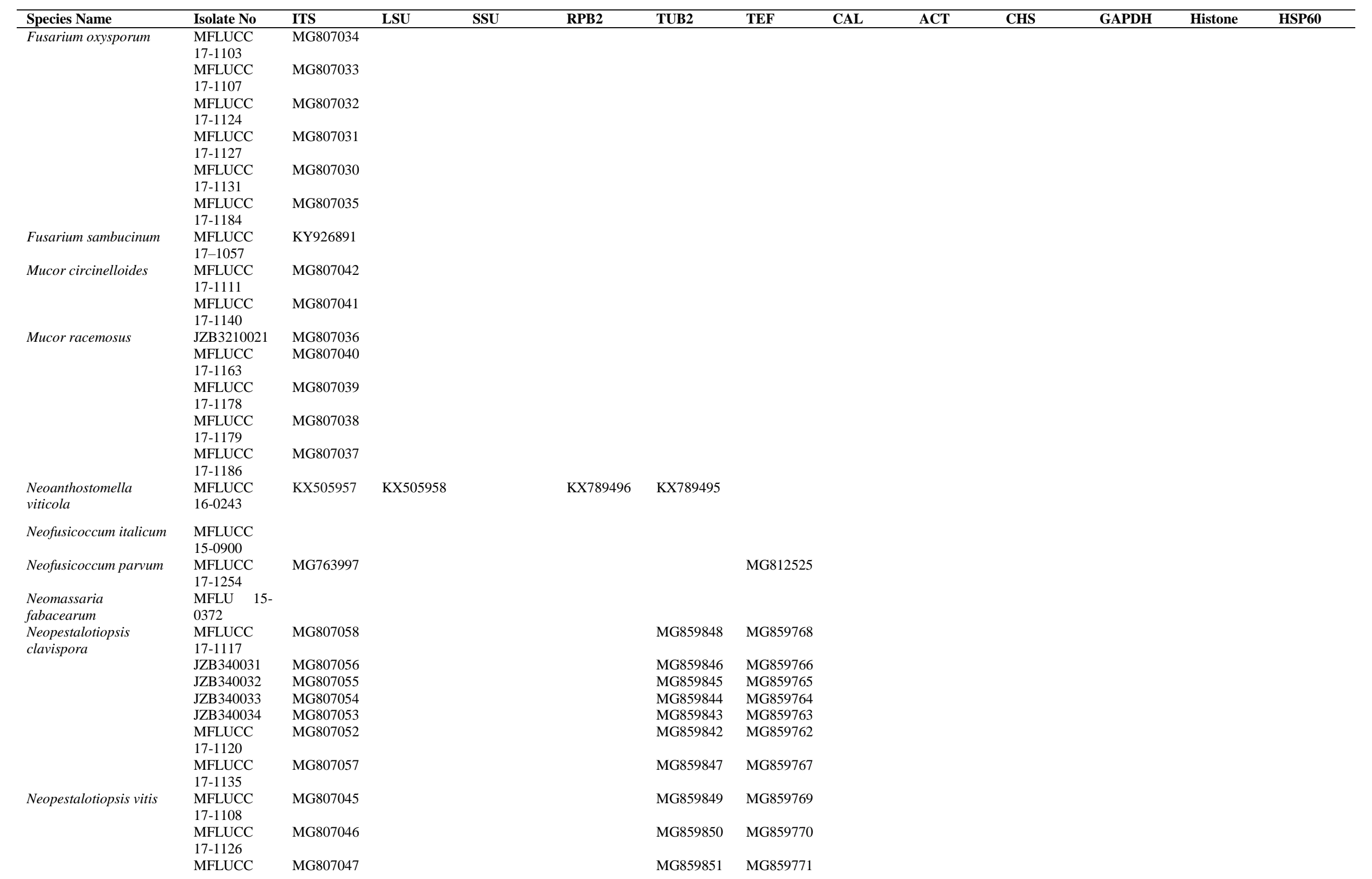




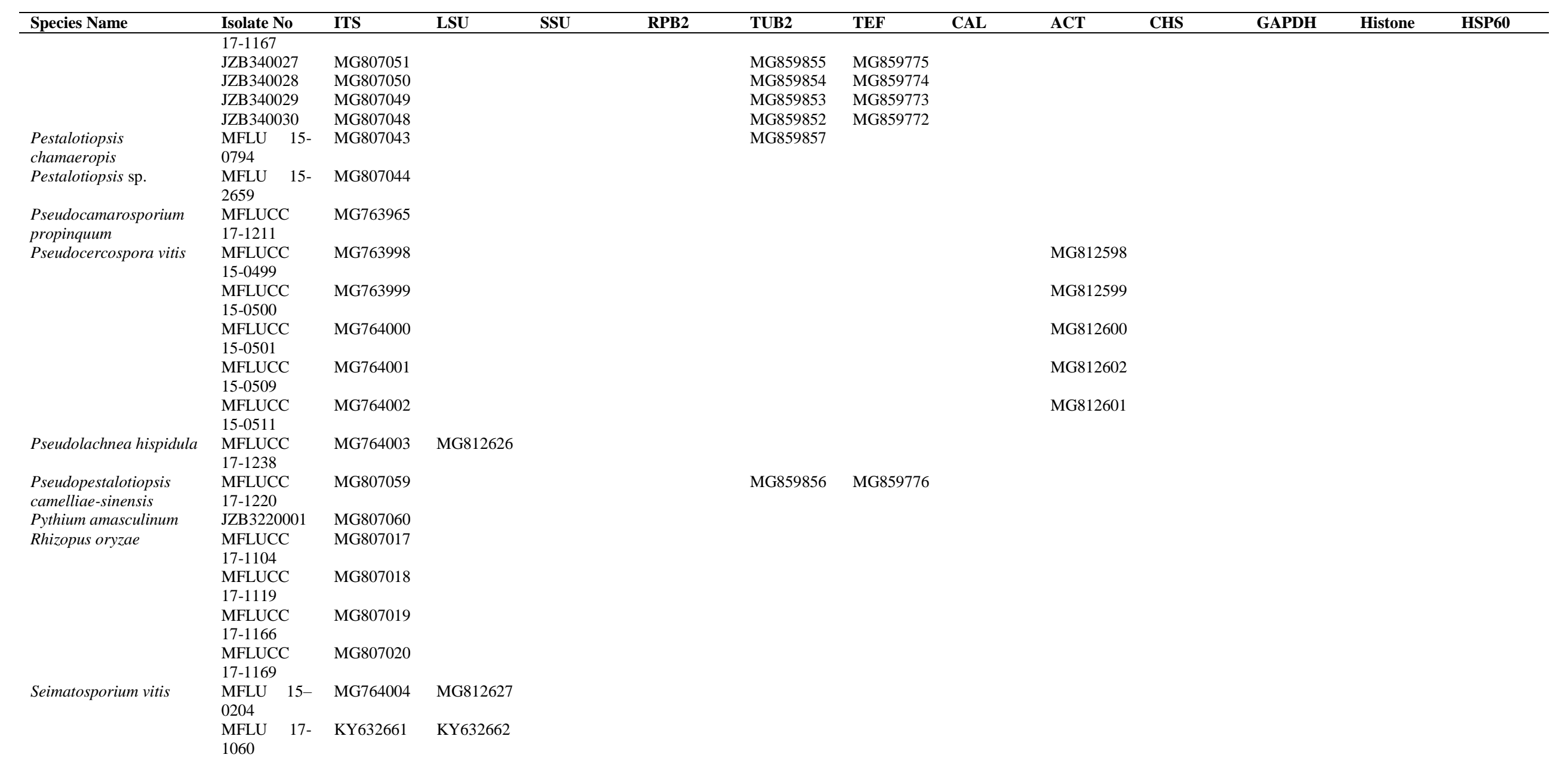




\section{Acknowledgements}

This work was financially supported by Beijing Talent Program for Dr. JiYe Yan, CARS-30 and JNKYT201605. RS Jayawardena would like to thank P. Abewikrama for helping to do the sequencing. Ausana Mapook is grateful to Research and Researchers for Industries (RRI) PHD57I0012 under the Thailand Research Fund for providing financial support.

\section{References}

Ahmad S, Iqbal SH, Khalid AN. 1997 - Fungi of Pakistan. Sultan Ahmad Mycological Society of Pakistan, pp248.

Ariyawansa HA, Tanaka K, Thambugala KM, Phookamsak R et al. 2014 - A molecular phylogenetic reappraisal of the Didymosphaeriaceae (= Montagnulaceae). Fungal Diversity 68, 69-104.

Ariyawansa HA, Hyde KD, Jayasiri SC, Buyck B et al. 2015 - Fungal diversity notes 111-252 taxonomic and phylogenetic contributions to fungal taxa. Fungal Diversity 75, 27-274

Auger J, Esterio M, Ricke G, Perez I. 2004 - Black dead arm and basal canker of Vitis vinifera cv. red globe cause by Botryosphaeria obtuse in Chile. Plant Disease 88, 1286.

Aveskamp MM, de Gruyter H, Woudenberg J, Verkley G et al. 2010 - Highlights of the Didymellaceae: a polyphasic approach to characterize Phoma and related pleosporalean genera. Studies in Mycology 65, 1-60.

Baroncelli R, Sreenivasaprasad S, Lane CR, Thon MR et al. 2014 - First report of Colletotrichum acutatum sensu lato (Colletotrichum godetiae) causing anthracnose on grapevine (Vitis vinifera) in the United Kingdom. New Disease Report 29, 26.

Barr ME. 2002 - Teichosporaceae, another family in the Pleosporales. Mycotaxon 82:373-389.

Bennett MD, Leitch IJ. 2012 - "Royal Botanic Gardens, Kew: Plant DNA C-values database, release 6.0". Royal Botanic Gardens, Kew.

Bensch K, Groenewald JZ, Dijksterhuis J, Starink-Willemse M et al. 2010 - Species and ecological diversity within the Cladosporium cladosporioides complex (Davidiellaceae, Capnodiales). Studies in Mycology 67, 1-96.

Bensch K, Groenewald JZ, Braun U, Dijksterhuis J et al. 2015 - Common but different: The expanding realm of Cladosporium. Studies in Mycology 82, 23-74.

Boonmee S, Phookamsak R, Hongsanan S, Doilom M et al. 2017 - Mycosphere notes 51-101. Revision of genera in Perisporiopsidaceae and Pseudoperisporiaceae and other Ascomycota genera incertae sedis. Mycosphere 8, 1695-1801.

Cai L, Hyde KD, Taylor PWJ, Weir B et al. 2009 - A polyphasic approach for studying Colletotrichum. Fungal Diversity 39, 183-204.

Casieri L, Hofstetter V, Viret O, Gindro K. 2009 - Fungal communities living in the wood of different cultivars of young Vitis vinifera plants. Phytopathologia Mediterrenia 48, 73-83.

Cesati V, De Notaris G. 1863 - Schema di classificazione degle sferiacei italici aschigeri piu' o meno appartenenti al genere Sphaeria nell'antico significato attribuitoglide Persono. Commentario della Societa Crittogamologica Italiana 1, 177-420.

Chen Q, Jiang JR, Zhang GZ, Cai L et al. 2015 - Resolving the Phoma enigma. Studies in Mycology 82, 137-217.

Chen Q, Hou LW, Duan WJ, Crous PW et al. 2017 - Didymellaceae revisited. Studies in Mycology $87,105-159$.

Chethana KWT, Zhou Y, Zhang W, Liu M et al. 2017 - Coniella vitis sp. nov. is the common pathogen of white rot in Chinese vineyards. Plant Disease 101, 2123-2136.

Chomnunti P, Hongsanan S, Aguirre-Hudson B, Tian Q et al. 2014 - The sooty moulds. Fungal Diversity 66, 1-36.

Corda ACI 1831 - Die Pilze Deutschlands. In: Sturm J (ed) Deutschlands Flora in Abbildungen nach der Natur mit Beschreibungen. Sturm, Nürnberg vol. 3, Abt. 12, 33-64, tab, 21-32.

Corda ACJ. 1833 - Deutschlands Flora, Abt. III. Die Pilze Deutschlands 3-13:65-96.

Submitted 30 November 2017, Accepted 29 January 2018, Published online 5 February 2018

Corresponding Authors: JY Yan - e-mail - jiyeyan@vip.163.com and RS Jayawardena - e-mail -

ruvi.jaya@yahoo.com 
Crous PW, Braun U, Hunter GC, Wingfield MJ et al. 2013 - Phylogenetic lineages in Pseudocercospora. Studies in Mycology 75, 37-114.

Crous PW, Wingfield MJ, Schumacher RK, Summerell BA et al. 2014 - Fungal planet description sheets: 281-319. Persoonia 33, 212-289.

Dai DQ, Bahkali AH, Ariyawansa HA, Li WJ et al. 2016 - Neokalmusia didymospora sp. nov. (Didymosphaeriaceae) from bamboo. Sydowia 68, 17-25.

Daranagama DA, Camporesi E, Jeewon R, Liu X et al. 2016 - Taxonomic rearrangement of Anthostomella (Xylariaceae) based on a multigene phylogeny and morphology. Cryptogamie Mycologie 37, 509-538.

de Gruyter J, Noordeloos ME, Boerema GH. 1998 - Contributions towards a monograph of Phoma (Coelomycetes) - I. 3. Section Phoma: taxa with conidia longer than $7 \mu \mathrm{m}$. Persoonia 16. 471-490.

den Breeÿen A, Groenewald JZ, Verkley GJ, Crous PW. 2006 - Morphological and molecular characterisation of Mycosphaerellaceae associated with the invasive weed, Chromolaena odorata. Fungal Diversity 23, 89-110.

Dissanayake AJ, Zhang W, Mei L, Chukeatirote E et al. 2015 - Lasiodiplodia pseudotheobromae causes pedicel and peduncle discolouration of grapes in China. Australasian Plant Pathology 10, article 21.

Dissanayake AJ, Philips AJL, Li XH, Hyde KD. 2016 - Botryosphaeriaceae: Current status of genera and species. Mycosphere 7, 1001-1073.

Dissanayake AJ, Phillips AJL, Hyde KD, Yan JY, Li XH 2017 - The current status of species in Diaporthe. Mycosphere 8, 1106-1156.

Farr ML. 1973 - An annotated list of Spegazzini's fungus taxa, Vol. 1. Bibliotheca Mycology 35, $1-823$.

Fischer M, Schneider P, Kraus C, Molnar M et al. 2016 - Grapevine trunk disease in German viticulture: occurence of lesser known fungi and first report of Phaeoacremonium viticola and $P$. fraxinopennsylvanicum. Vitis 55, 145-156.

Garcia-Benavides P, Martin Zamorano P, Ocete Perez CA, Maistrello L et al. 2013 - Biodiversity of pathogenic wood fungi isolated from Xylotrechus arvicola (Olivier) galleries in vine shoots. Journal International des Sciences de la Vigne et duVin 47, 73-81.

Gonzalez V, Tello ML. 2011 - The endophytic mycota associated with Vitis vinifera in central Spain. Fungal Diversity 47, 29-42.

Grunow A, Hauck F, Limpricht G, Luerssen Ch et al. 1887 - Family Chaetomieae. Rabenh. Krypt. Fl., Edn 2 (Leipzig) 1.2:153

Hall TA. 1999 - BioEdit: a user-friendly biological sequence alignment editor and analysis program for Windows 95/98/NT. Nucleic Acids Research 41, 95-98.

Hawksworth DL, Wells H. 1973 - Ornamentation on the terminal hairs in Chaetomium kunze ex fr. and some allied genera. Mycological Papers 134, 1-24.

Hillis DM, Bull JJ 1993 - An empirical test of bootstrapping as a method for assessing confidence in phylogenetic analysis. Systematic Biology 42, 182-192.

Hyde KD, Cai L, McKenzie EHC, Yang YL et al. 2009 - Colletotrichum: a catalogue of confusion. Fungal Diversity, 39, 1-17.

Hyde KD, Cai L, Cannon PF, Crouch JA et al. 2009b - Colletotrichum-names in current use. Fungal Diversity 39, 147-182.

Hyde KD, Jones EBG, Liu JK, Ariyawansha H et al. 2013 - Families of Dothideomycetes. Fungal Diversity 63, 1-313.

Hyde KD, Nilsson RH, Alias SA, Ariyawansa HA et al. 2014 - One stop shop: backbones trees for important pytopathogenic genera: I. Fungal Diversity 67, 21-125.

Hyde KD, Hongsanan S, Jeewon R, Bhat DJ et al. 2016 - Fungal diversity notes 367491:taxonomic and phylogenetic contributions to fungal taxa. Fungal Diversity 80, 1-270. 
Hyde KD, Norphanphoun C, Bazzicalupo A, Karunarathna A et al. 2017 - Fungal diversity notes 603-715: taxonomic and phylogenetic notes on genera and species. Fungal Diversity 87, $1-235$.

Index Fungorum 2018 - http://www.indexfungorum.org/names/names.asp.

Jaklitsch WM, Olariaga I, Voglmayr H. 2016 - Teichospora and the Teichosporaceae. Mycological Progress 15, 1-20.

Jarvis WR, Traquair JA. 1984 - Bunch rot of grapes caused by Aspergillus aculeatus. Plant Disease $68,718-719$.

Jayasiri SC, Hyde KD, Ariyawansa HA, Bhat J et al. 2015 - The Faces of Fungi database: Fungal names linked with morphology, molecular and human attributes. Fungal Diversity 74, 318.

Jayawardena RS, Zhang W, Liu M, Maharachchikumbura SSN et al. 2015 - Identification and characterization of Pestalotiopsis-like fungi related to grapevine diseases in China. Fungal Biology 119, 348-361.

Jayawardena RS, Liu M, Maharachchikumbura SS, Zhang W et al. 2016a - Neopestalotiopsis vitis sp. nov. causing grapevine leaf spot in China. Phytotaxa 258, 63-74.

Jayawardena RS, Hyde KD, Damm U, Cai L et al. 2016b - Notes on currently accepted species of Colletotrichum. Mycosphere 7, 1192-1260.

Jayawardena RS, Purahong W, Zhang W, Wubet T et al. 2018 - Biodiversity of fungi on Vitis vinifera $\mathrm{L}$. revealed by traditional and high resolution culture-independent approaches. Fungal Diversity (In press).

Katoh K, Toh H. 2008 - Recent developments in the MAFFT multiple sequence alignment program. Briefings in Bioinformatics 9, 276-285.

Kirk PM, Cannon PF, David JC, Stalpers JA. 2001 - Ainsworth and Bisby's dictionary of the fungi. $9^{\text {th }}$ edn. CAB International, Wallingford, UK.

Kirk PM, Cannon PF, David JC, Stalpers JA. 2008 - Ainsworth and Bisby's dictionary of the fungi. $10^{\text {th }}$ edn. CAB International, Wallingford, UK.

Kishino H, Hasegawa M 1989 - Evaluation of the maximum likelihood estimate of the evolutionary tree topologies from DNA sequence data. Journal of Molecular Evolution 29, $170-179$.

Kohlmeyer J, Volkmann- Kohlmeyer B. 2000 - Fungi on Juncus roemerianus 14. Three New Coelomycetes, including Floricola, anam.-gen. nov. Botanica Marina 43, 385-392.

Leslie JF, Summerell BA. 2006 - The Fusarium Laboratory Manual. Blackwell Publishing Ltd, Iowa

Levi MP, Preston RD. 1965 - A chemical and microscopic examination of the action of the soft-rot fungus Chaetomium globosum on beechwood (Fagus sylv.). Holzforschung 19, 183-190.

Liew ECY, Aptroot A, Hyde KD. 2000 - Phylogenetic significance of the pseudoparaphyses in Loculoascomycete taxonomy. Molecular Phylogenetic and Evolution 16, 392-402.

Link HF. 1809 - Observations in ordines plantarum naturals, Dissetatio I. Mag Ges Naturf Freunde Berlin.3, 3-42.

Lin CG, Dai DQ, Bhat DJ, Hyde KD et al. 2017 - Alfaria avenellae sp. nov. from Italy. Phytotaxa 332, 67-74.

Liu JK, Phookamsak R, Doilom M, Wikee S et al. 2013 - Towards a natural classification of Botryosphaeriales. Fungal Diversity 57, 149-210.

Liu JK, Hyde KD, Jones EBG, Ariyawansa HA et al. 2015 - Fungal diversity notes 1-110: taxonomic and phylogenetic contributions to fungal species. Fungal Diversity 72, 1-197.

Liu JK, Hyde KD, Jeewon R, Phillips AJL et al. 2017 - Ranking higher taxa using divergence times: a case study in Dothideomycetes. Fungal Diversity 84, 75-99.

Locquin M. 1984 - Mycologie Générale et Structurale. Masson, Paris.

Lombard L, Houbraken J, Decock C, Samson RA et al. 2016 - Generic hyper-diversity in Stachybotriaceae. Persoonia 36, 156. 
Luque J, Martos S, Phillips AJL. 2005 - Botryosphaeria viticola sp. nov. on grapevines: a new species with a Dothiorella anamorph. Mycologia 97, 1111-1121.

Maharachchikumbura SSN, Guo LD, Chukeatirote E, Bahkali AH et al. 2011 - Pestalotiopsismorpholgy, phylogeny, biochemistry and diversity. Fungal Diversity 50, 167-187.

Maharachchikumbura SSN, Guo LD, Cai L, Chukeatirote E et al. 2012 - A multi-locus backbone tree for Pestalotiopsis, with a polyphasic characterization of 14 new species. Fungal Diversity 56, 95-129.

Maharachchikumbura SSN, Crous PW, Groenewald JZ, Xu J et al. 2014 - Pestalotiopsis revisited. Studies in Mycology 79, 121-186.

Maharachchikumbura SSN, Hyde KD, Jones EBG, McKenzie EHC et al. 2015 - Towards a natural classification and backbone tree for Sordariomycetes. Fungal Diversity 72, 199-301.

Maharachchikumbura SN, Hyde KD, Jones EBG, McKenzie EHC et al. 2016a - Families of Sordariomycetes. Fungal Diversity 79, 1-317.

Maharachchikumbura SSN, Larigon P, Hyde KD, Al-Sadi AM, et al. 2016b - Characteriztion of Neopestalotiopsis, Pestalotiopsis and Truncatella species associated with grapevine trunk disease in France. Phytopathologia Mediterrenia 55, 380-390.

Manamgoda DS, Cai L, Bahkali AH, Chukeatirote E et al. 2011 - Cochliobolus: an overview and current status of species. Fungal Diversity 51, 3-42.

Manamgoda DS, Cai L, McKenzie EH, Crous PW et al. 2012 - A phylogenetic and taxonomic reevaluation of the Bipolaris-Cochliobolus-Curvularia complex. Fungal Diversity 56, 131144.

Manamgoda DS, Rossman AY, Castlebury LA, Crous PW et al. 2014 - The genus Bipolaris. Studies in Mycology 79, 221-288.

Marin-Felix Y, Groenewald JZ, Cai L, Chen Q et al. 2017 - Genera of phytopathogenic fungi: GOPHY 1. Studies in Mycology 86, 99-216.

Mulenko W, Majewski T, Ruszkiewicz-Michalska M. 2008 - A Preliminary Checklist of Micromycetes in Poland. W. Szafer Institute of Botany, Polish Academy of Sciences 9, 752.

Nag Raj TR. 1993 - Coelomycetous anamorphs with appendage-bearing conidia. Mycologue Publications, Waterloo, Ontario, pp1-1101.

Neergaard P. 1950 - Mycological Notes III. 7. Colletotrichum godetiae Neerg. 8. Phoma bellidis Neerg. 9. Zygosporium parasiticum (Grove) Bunting \& Mason. 10. Peronospora dianthicola Barthelet. Friesia 4, 72-80.

Nees von Esenbeck CDG. 1817 - System der Pilze und Schwämme. 2, 1-334.

Nitschke 1869 - Verh. Naturhist. Vereines Preuss. Rheinl. 26, 74.

Nylander JAA. 2004 - MrModeltest 2.0. Program distributed author. Evolutionary Biology Centre, Uppsala University.

Ogórek R, Lejman A, Pusz W, Miłuch A et al. 2012 - Characteristics and taxonomy of Cladosporium fungi. Mikologia lekarska 19, 80-85.

Page RDM. 1996 - TreeView: an application to display phylogenetic trees on personal computers. Computer Applications in the Biosciences 12, 357-358.

Pan FY, Huang Y, Lin L, Zhou YM et al. 2016 - First report of Colletotrichum capsici causing grape ripe rot in Guangxi, China. Plant Disease 100, pp2531.

Peng LJ, Sun T, Yang YL, Cai L et al. 2013 - Colletotrichum species on grape in Guizhou and Yunnan provinces, China. Mycoscience 54, 29-41.

Petch T. 1938 - British Hypocreales. Transactions of the British Mycological Society 21, 243-305.

Phillips AJL, Alves A, Abdollahzadeh J, Slippers B et al. 2013 - The Botrysphaeriaceae: genera and species known from culture. Studies in Mycology 76, 51-167.

Pitt WM, Úrbez-Torres JR, Trouillas FP. 2013 - Dothiorella vidmadera, a novel species from grapevines in Australia and notes on Spencermartinsia. Fungal Diversity 61, 209-219.

Réblová M, Gams W, Seifert KA. 2011 - Monilochaetes and allied genera of the Glomerellales, and a reconsideration of families in the Microascales. Studies in Mycology 68, 163-191. 
Ronquist F, Huelsenbeck JP. 2003 - MrBayes 3: Bayesian phylogenetic inference under mixed models. Bioinformatics 19, 1572-1574.

Saccardo PA. 1880 - Fungi Gallici lecti a cl. viris P. Brunaud, Abb. Letendre, A. Malbranche, J. Therry, vel editi in Mycotheca Gallica C. Roumeguèri. Series II. Michelia 2, 39-135.

Saccardo PA. 1883 - Sylloge Pyrenomycetum, Vol. II. Sylloge Fungorum. 2, 1-813.

Sanoamuang N, Jitjak W, Rodtong S, Whalley AJS. 2013 - Gelatinomyces siamensis gen. sp. nov. (Ascomycota, Leotiomycetes, incertae sedis) on bamboo in Thailand. IMA Fungus 4, 7187.

Seaver FJ. 1909 - The Hypocreales of North America. I. Mycologia 1, 41-76.

Seaver FJ. 1911 - The Hypocreales of North America. IV. Mycologia 3, 207-230.

Seifert K, Morgan-Jones G, Gams W, Kendrick B. 2011 - The Genera of Hyphomycetes. [CBS Biodiversity Series 9]. CBS KNAW Fungal Biodiversity Centre, Utrecht.

Senanayake IC, Maharachchikumbura SS, Hyde KD, Bhat JD et al. 2015 - Towards unraveling relationships in Xylariomycetidae (Sordariomycetes). Fungal Diversity 73, 73-144.

Shoemaker RA. 1959 - Nomenclature of Drechslera and Bipolaris, grass parasites segregated from Helminthosporium. Canadian Journal of Botany 37, 879-887.

Silvestro D, Michalak I. 2010 - raxmlGUI: a graphical front-end for RAxML. Organisms Diversity and Evolution 12, 335-337.

Spooner BM. 1981 - New records and species of British microfungi. Transactions of the British Mycological Society 76, 265-301.

Stace CA. 2010 - New Flora of the British Isles (Third ed.). Cambridge, U.K.: Cambridge University Press. ISBN 9780521707725.

Swofford DL. 2002 - PAUP* 4.0: phylogenetic analysis using parsimony (* and other methods). Sinauer Associates, Sunderland.

Thambugala KM, Ariyawansa HA, Li YM, Boonmee S et al. 2014 - Dothideales. Fungal Diversity $68,105-158$.

Thambugala KM, Hyde KD, Tanaka K, Tian Q et al. 2015 - Towards a natural classification and backbone tree for Lophiostomataceae, Floricolaceae, and Amorosiaceae fam. nov. Fungal Diversity 74, 199-266.

Thambugala KM, Wanasinghe DN, Phillips AJL, Camporesi E et al. 2017 - Mycosphere notes 150: grass (Poaceae) inhabiting Dothideomycetes. Mycosphere 8, 697-796.

Thompson JD, Gibson TJ, Plewniak F, Jeanmougin F et al. 1997 - The Clustal X windows interface: flexible strategies for multiple sequence alignment aided by quality analysis tools. Nucleic Acids Research 24, 4876-4882.

Tibpromma S, Hyde KD, Jeewon R, Maharachchikumbura SS et al. 2017 - Fungal diversity notes 491-602: taxonomic and phylogenetic contributions to fungal taxa. Fungal diversity 83, $1-$ 261.

Trouillas FP, Úrbez-Torres JR, Gubler WD. 2010 - Diversity of diatrypaceous fungi associated with grapevine canker diseases in California. Mycologia 102, 319-336.

Trouillas FP, Pitt WM, Sosnowski MR, Huang R et al. 2011 - Taxonomy and DNA phylogeny of Diatrypaceae associated with Vitis vinifera and other woody plants in Australia. Fungal Diversity 49, 203-223.

Tulloch M. 1972 - The genus Myrothecium Tode ex Fr. Mycological Papers 130, 1-42.

Udayanga D, Liu XZ, Crous PW, McKenzie EHC et al. 2012 - A multi-locus phylogenetic evaluation of Diaporthe (Phomopsis). Fungal Diversity 56, 157-171.

Udayanga D, Castlebury LA, Rossman AY, Hyde KD. 2014 - Species limits in Diaporthe: molecular re-assessment of D. citri, D. cytosporella, D. foeniculina and D. rudis. Persoonia 32, 83-101.

Udayanga D, Castlebury LA, Rossman AY, Chukeatirote E et al. 2015 - The Diaporthe sojae species complex: phylogenetic reassessment of pathogens associated with soybean, cucurbits and other field crops. Fungal Biology 119, 383-407. 
Úrbez-Torres JR, Leavitt GM, Guerrero JC, Guevara J et al. 2008 - Identification and pathogenicity of Lasiodiplodia theobromae and Diplodia seriata, the causal agents of bot canker disease of Grapevines in Mexico. Plant Disease 92, 519-529.

Úrbez-Torres JR, Peduto F, Smith RJ, Gubler WD. 2013 - Phomopsis Dieback: A grapevine trunk disease caused by Phomopsis viticola in California. Plant Disease 97, 1571-1579.

Úrbez-Torres JR, Peduto F, Striegler RK, Urrea-Romero KE et al. 2012 - Characterization of fungal pathogens associated with grapevine trunk diseases in Arkansas and Missouri. Fungal Diversity 52, 169-189.

Úrbez-Torres JR. 2011 - The status of Botryosphaeriaceae species infecting grapevines. Phytopathologia Mediterrenia 50, 5-45.

van Niekerk JM, Crous PW, Groenewald JZ, Fourie PH et al. 2004 - DNA phylogeny, morphology and pathogenicity of Botryosphaeria species on grapevines. Mycologia 96, 781-798.

Viala P, Boyer, G. 1891 - Une nouvelle maladie des raisins. Revue Génerale de Botanique. 3, 369371.

Videira SIR, Groenewald JZ, Nakashima C, Braun U et al. 2017 - Mycosphaerellaceae-chaos or clarity?. Studies in Mycology 87, 257-421.

von Arx JA, Guarro J, Figueras MJ 1986 - The ascomycete genus Chaetomium. J. Cramer. Nova Hedwigia 84, pp 162.

Walker MA. 2015 - The Genus Vitis, its species, and its rootstocks. In: Wilcox WF, Gubler WD, Uyemoto JK (eds.) Compendium of grape diseases, disorders and pests. American Phytopathological Society, USA, pp 3-5.

Walther G, Pawłowska J, Alastruey-Izquierdo A, Wrzosek M et al. 2013 - DNA barcoding in Mucorales: an inventory of biodiversity. Persoonia 30, 11-47.

Wang Y, Xu L, Ren W, Zhao D et al. 2012 - Bioactive metabolites from Chaetomium globosum L18, an endophytic fungus in the medicinal plant Curcuma wenyujin. Phytomedicine 19, 364-368.

Weir BS, Johnston PR, Damm U. 2012 - The Colletotrichum gloeosporioides species complex. Studies in Mycology 73, 115-180.

Wijayawardene NN, Crous PW, Kirk PM, Hawksworth DL et al. 2014a - Naming and outline of Dothideomycetes-2014 including proposals for the protection or suppression of generic names. Fungal Diversity 69, 1-55.

Wijayawardene NN, Hyde KD, Bhat DJ, Camporesi E et al. 2014b - Camarosporium-like species are polyphyletic in Pleosporales; introducing Paracamarosporium and Pseudocamarosporium gen. nov. in Montagnulaceae. Cryptogamie Mycologie 35, 177198.

Wijayawardene NN, Hyde KD, Rajeshkumar KC, Hawksworth DL et al. 2017 - Notes for genera: Ascomycota. Fungal Diversity 86, 1-594.

Wijayawardene NN, Hyde KD, Lumbsch T, Liu JK et al. 2018 - Outline of Ascomycota - 2017. Fungal Diversity 88, 167-263.

Winter G. 1885 - Pilze: Ascomyceten. In: Rabenhorst's KryptogamenFlora von Deutschland, Oesterreich und der Schweiz 1, 1-928.

Woudenberg JHC, Aveskamp MM, de Gruyter J, Spiers AG et al. 2009 - Multiple Didymella teleomorphs are linked to the Phoma clematidina morphotype. Persoonia 22, 56-62.

Yan JY, Jayawardena MMRS, Goonasekara ID, Wang Y et al. 2015 - Diverse species of Colletotrichum associated with grapevine anthracnose in China. Fungal Diversity 71, 233246.

Yilmaz N, Houbraken J, Hoekstra ES, Frisvad JC et al. 2012 - Delimitation and characterisation of Talaromyces purpurogenus and related species. Persoonia 29, pp39.

Zhuang WY Ed. 2005 - Fungi of northwestern China. Mycotaxon Ltd, Ithaca NY, pp 430.

Zhang TY. 2003 - Flora Fungorum Sinicorum. Alternaria. Science Press, Beijing, 16, pp284.

Zhang N, Castlebury LA, Miller AN, Huhndorf SM et al. 2006 - An overview of the systematics of the Sordariomycetes based on four-gene phylogeny. Mycologia 98, 1076-1087. 
Zhang Y, Wang HK, Fournier J, Crous PW et al. 2009 - Towards a phylogenetic clarification of Lophiostoma/Massarina and morphologically similar genera in the Pleosporales. Fungal Diversity 38, 255-251. 